\title{
GROUND-WATER CONDITIONS IN GEORGIA, 1993
}

\author{
By Charles N. Joiner and Alan M. Cressler
}

\section{U.S. GEOLOGICAL SURVEY}

Open File Report 94-118

Prepared in cooperation with the

GEORGIA DEPARTMENT OF NATURAL RESOURCES ENVIRONMENTAL PROTECTION DIVISION GEORGIA GEOLOGIC SURVEY

ALBANY WATER, GAS, AND LIGHT COMMISSION

CITY OF BRUNSWICK

GLYNN COUNTY

CITY OF VALDOSTA

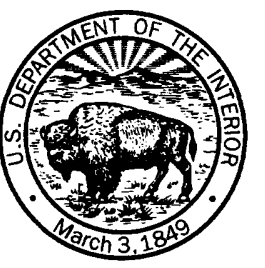

Atlanta, Georgia 


\title{
U.S. DEPARTMENT OF THE INTERIOR
}

\author{
Bruce Babbitt, Secretary
}

U.S. GEOLOGICAL SURVEY

Gordon P. Eaton, Director

For additional information, please write to:

District Chief

U.S. Geological Survey

3039 Amwiler Road

Peachtree Business Center

Suite 130

Atlanta, GA 30360-2824
Copies of this report may be purchased from:

U.S. Geological Survey

Earth Science Information Center

Open-File Reports Section

Denver Federal Center

Box 25286, Mail Stop 517

Denver, CO 80225 


\section{CONTENTS}

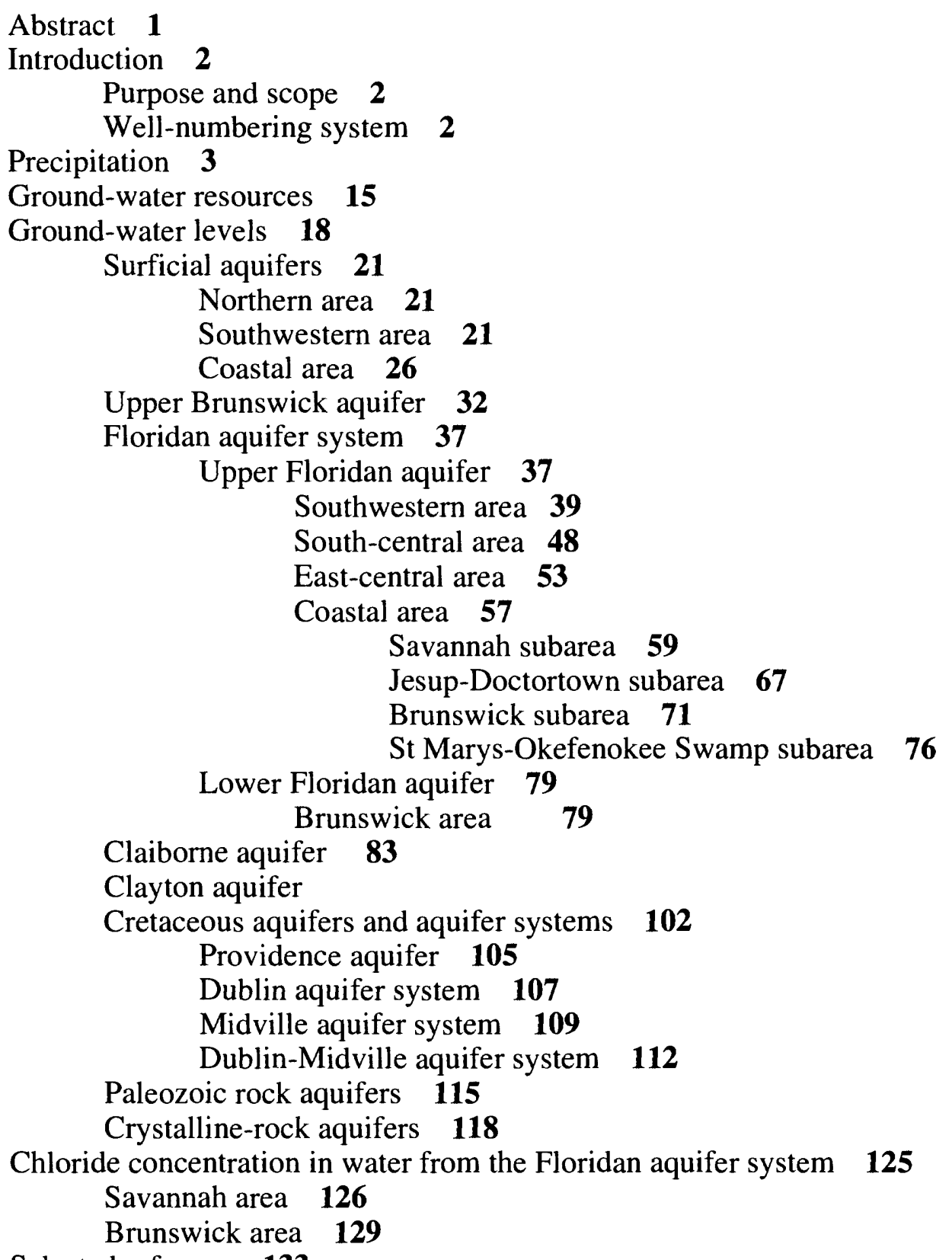

Selected references $\mathbf{1 3 3}$ 


\section{ILLUSTRATIONS}

Figure 1. Map showing locations of precipitation monitoring stations and mean annual precipitation in Georgia, 1941-70 4

Figures 2-11. Graphs showing cumulative monthly precipitation departure from long-term mean monthly precipitation (1961-90) and monthly departure and cumulative departure for 1993 for National Weather Service station:

2. Athens airport, Clarke County, Georgia 5

3. Atlanta airport, Fulton County, Georgia 6

4. Chattanooga airport, Hamilton County, Tennessee 7

5. Albany 3 SE, Dougherty County, Georgia 8

6. Augusta airport, Richmond County, Georgia 9

7. Waycross WSMO, Ware County, Georgia 10

8. Cleveland, White County, Georgia 11

9. Columbus airport, Muscogee County, Georgia 12

10. Macon airport, Bibb County, Georgia 13

Figures 12-14. Maps showing:

11. Savannah airport, Chatham County, Georgia 14

12. Areas of utilization of major aquifers and block diagram showing major aquifers and physiographic provinces of Georgia 17

13. Locations of observation wells for which hydrographs are included in this report 20

14. Locations of observation wells completed in the surficial aquifers

Figures 15-22. Hydrographs showing the water level in observation well:

15. 11AA01, Spalding County 23

16. 13M007, Worth County 24

17. 07H003, Miller County 25

18. 35P094, Chatham County 27

19. 37P116, Chatham County 28

20. 32R003, Bulloch County 29

21. $34 \mathrm{H} 438$, Glynn County $\mathbf{3 0}$

22. 32L017, Wayne County 31

Figure 23. Map showing locations of observation wells completed in the upper Brunswick aquifer 33

Figures 24-26. Hydrographs showing the water level in observation well:

24. 31 U009, Bulloch County 34

25. 32L016, Wayne County 35

26. 34H437, Glynn County 36

Figure 27. Map showing subareas and locations of observation wells completed in the Upper Floridan aquifer $\mathbf{3 8}$

Figures 28-42. Hydrographs showing the water level in observation well:

28. 09F520, Decatur County $\mathbf{4 0}$

29. 08G001, Miller County 41

30. 06F001, Seminole County 42

31. 13L012, Dougherty County $\mathbf{4 3}$

32 10G313, Mitchell County 44

33 13L003, Dougherty County 45

34. 13J004, Mitchell County $\mathbf{4 6}$

35. 15L020, Worth County 47

36. 18K049, Tift County 49

37. 18H016, Cook County 50 


\section{ILLUSTRATIONS--Continued}

Figures 28-42. Hydrographs showing the water level in observation well:--Continued

38. 19E009, Lowndes County $\mathbf{5 1}$

39. 19F039, Lowndes County $\mathbf{5 2}$

40. 21T001, Laurens County $\mathbf{5 4}$

41. 25Q001, Montgomery County $\mathbf{5 5}$

42. 26R001, Toombs County $\mathbf{5 6}$

Figure 43. Map showing subareas and locations of observation wells completed in the Upper Floridan aquifer in the coastal area $\mathbf{5 8}$

Figures 44-59. Hydrographs showing the water level in observation well:

44. 36Q008, Chatham County $\mathbf{6 0}$

45. 36Q020, Chatham County $\mathbf{6 1}$

46. 38Q002, Chatham County 62

47. 39Q003, Chatham County 63

48. 32R002, Bulloch County 64

49. 34N089, Liberty County $\mathbf{6 5}$

50. 35M013, McIntosh County $\mathbf{6 6}$

51. 30L003, Wayne County 68

52. 32L015, Wayne County 69

53. 33M004, Long County 70

54. 33 H127, Glynn County 72

55. 34H403, Glynn County $\mathbf{7 3}$

56. 33 H133, Glynn County $\mathbf{7 4}$

57. 34 H371, Glynn County $\mathbf{7 5}$

58. 33E027, Camden County $\mathbf{7 7}$

59. 27E004, Charlton County 78

Figure 60. Map showing locations of observation wells completed in the Lower Floridan aquifer 80

Figures 61-62. Hydrographs showing the water level in observation well:

61. 34H391, Glynn County $\mathbf{8 1}$

62. 33J044, Glynn County 82

Figure 63. Map showing locations of observation wells completed in the Claiborne aquifer 84

Figures 64-71. Hydrographs showing the water level in observation well:

64. 06K010, Early County $\mathbf{8 5}$

65. 09M009, Randolph County 86

66. $11 \mathrm{~K} 002$, Dougherty County $\mathbf{8 7}$

67. 11L001, Dougherty County $\mathbf{8 8}$

68. 12L019, Dougherty County $\mathbf{8 9}$

69. 13L011, Dougherty County 90

70. 13M005, Worth County 91

71. 14P015, Crisp County 92

Figure 72. Map showing locations of observation wells completed in the Clayton aquifer 94

Figures 73-79. Hydrographs showing the water level in observation well:

73. 06K009, Early County 95

74. 07N001, Randolph County 96

75. 09N001, Terrell County 97

76. 11L002, Dougherty County 98

77. 13L002, Dougherty County 99 


\section{ILLUSTRATIONS--Continued}

Figures 73-79. Hydrographs showing the water level in observation well:--Continued 78. $11 \mathrm{~K} 005$, Dougherty County $\mathbf{1 0 0}$

79. 14P014, Crisp County 101

Figure 80. Map showing locations of observation wells completed in Cretaceous aquifers and aquifer systems 103

Figures 81-87. Hydrographs showing the water level in observation well:

81. 06S001, Chattahoochee County 104

82. 12L021, Dougherty County 106

83. 18U001, Twiggs County 108

84. 18T001, Pulaski County $\mathbf{1 1 0}$

85. 28X001, Burke County 111

86. 30AA04, Richmond County $\mathbf{1 1 3}$

87. 23X027, Washington County 114

Figure 88. Map showing location of observation well completed in the Paleozoic rock aquifer 116

89. Hydrograph showing the water level in observation well 03PP01, Walker County 117

90. Map showing locations of observation wells completed in crystalline-rock aquifers 119

Figures 91-95. Hydrographs showing the water level in observation well:

91. 10DD02, Fulton County 120

92. 19HH12, Madison County 121

93. 11FF04, DeKalb County 122

94. 21BB04, Greene County $\mathbf{1 2 3}$

95. 16MM03, White County 124

Figure 96. Map showing locations of chloride monitoring wells completed in the Floridan aquifer system in the Savannah area 127

Figure 97. Graphs showing chloride concentrations in water from the Upper and Lower Floridan aquifers in the Savannah area $\mathbf{1 2 8}$

98. Map showing locations of chloride-monitoring wells completed in the Floridan aquifer system in the Brunswick area $\mathbf{1 3 0}$

Figures 99 -100. Graphs showing:

99. Chloride concentration in water from the Floridan aquifer system in the southern Brunswick area 131

100. Chloride concentration in water from the Floridan aquifer system in the northern Brunswick area 132

\section{TABLES}

Table 1. Previous reports in this series 3

2. Aquifer and well characteristics in Georgia $\mathbf{1 6}$

3. Observation wells for which hydrographs are included in this report $\mathbf{1 8}$

4. Observation wells for which chloride-concentration graphs are included in this report 125 


\title{
CONVERSION FACTORS AND VERTICAL DATUM
}

\section{CONVERSION FACTORS}

\author{
Multiply by $\quad$ to obtain
}

\section{Length}

$\begin{array}{rll}\text { inch (in.) } & 2.540 & \text { centimeter } \\ \text { foot (ft) } & 0.3048 & \text { meter } \\ \text { mile (mi) } & 1.609 & \text { kilometer }\end{array}$

$\underline{\text { Volumetric }}$

gallon per minute

(gal/min)

million gallons per day

(Mgal/d)
$0.06309 \quad$ liter per second

$0.04381 \quad$ cubic meter per second

43.81 liter per second

\section{VERTICAL DATUM}

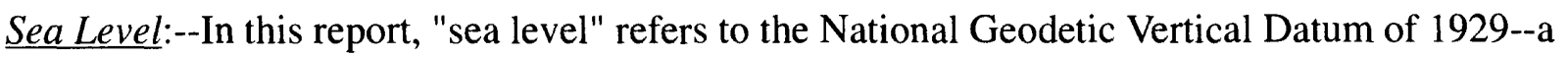
geodetic datum derived from a general adjustment of the first-order level nets of both the United States and Canada, formerly called "Sea Level Datum of 1929." 


\section{PREFACE}

This report was prepared in cooperation with the following agencies, whose assistance in collecting and compiling precipitation, water-level, and water-quality data during 1993 is gratefully acknowledged:

Georgia Department of Natural Resources

Environmental Protection Division

Georgia Geologic Survey

Albany Water, Gas, and Light Commission

City of Brunswick

Glynn County

City of Valdosta

National Oceanic and Atmospheric Administration

The report is the culmination of a concerted effort by personnel of the U.S. Geological Survey who collected, compiled, analyzed, verified, and organized the data, and who edited and assembled the report. In addition to the authors, who had primary responsibility for ensuring that the information contained herein is accurate and complete, the following individuals contributed substantially to the collection, processing, tabulation, and review of the data:

\author{
Robert J. Allen \\ George A. Bailey \\ Diane C. Burgoon \\ Carolyn A. Casteel \\ John S. Clarke \\ John H. Doss \\ Gregory B. Donley \\ Donald J. Everett \\ Willis G. Hester \\ David W. Hicks \\ Stephen H. Jones \\ Richard E. Krause \\ William C. Lewis \\ James B. McConnell \\ Keith W. McFadden
}

\author{
Roger D. McFarlane \\ Kristen B. McSwain \\ R. Terry Nichols \\ Michael F. Peck \\ Helen M. Peterson \\ Forest M. Platt \\ Mark S. Reynolds \\ Welby L. Stayton \\ Eric A. Steinnagel \\ Charles G. Somerindyke \\ Rodney L. Thompson \\ Christopher T. West \\ Blaine T. White \\ Michael J. Zieg
}

Data used in this report may be obtained upon request from the U.S. Geological Survey, Water Resources Division, Peachtree Business Center, Suite 130, 3039 Amwiler Road, Atlanta, GA 30360-2824.

[Cover: Hydrographs of well 12L019, U.S. Geological Survey test well 5, Dougherty County.] 


\title{
GROUND-WATER CONDITIONS IN GEORGIA, 1993
}

\author{
By \\ Charles N. Joiner and Alan M. Cressler
}

\begin{abstract}
Ground-water conditions during 1993 and period of record in Georgia were evaluated using data from precipitation, ground-water-level, and ground-water-quality monitoring networks. Data for 1993 included in this report are from precipitation records from 10 National Weather Service (NWS) stations, continuous water-level records from 72 wells, and chloride analyses from 13 wells.

Cumulative departures from long-term mean monthly precipitation in 1993 were below normal at 9 of the 10 NWS sites. Cumulative departures for the 10-year period (1984-93) were below normal at 6 of the 10 stations.

Annual mean ground-water levels in Georgia in 1993 ranged from about 3.2 feet (ft) higher to about $9.6 \mathrm{ft}$ lower than in 1992. Of the 72 wells summarized in this report, 30 wells had annual mean water levels that were higher and 42 wells had annual mean water levels that were lower in 1993 than in 1992. Record-high daily mean water levels were recorded in one well tapping the surficial aquifer, one well tapping the Upper Floridan aquifer, one well tapping the Claiborne aquifer, and one well tapping the crystalline-rock aquifers. These record highs were from about 0.1 to $0.7 \mathrm{foot}(\mathrm{ft}$ ) higher than previous record highs. Record-low daily mean water levels were recorded in one well tapping the surficial aquifer, two wells tapping the Upper Floridan aquifer, four wells tapping the Cretaceous aquifer, one well tapping the Dublin-Midville aquifer system, and one well tapping the crystalline-rock aquifers. These record lows were from about 0.1 to $7.2 \mathrm{ft}$ lower than previous record lows.

Chloride concentration in water from the Upper Floridan aquifer in most of coastal Georgia was below drinking water standards established by the Georgia Department of Natural Resources and the U.S. Environmental Protection Agency and has not changed appreciably with time. However, chloride concentration in water from some wells that tap the Floridan aquifer system in the Brunswick area exceeds the drinking water standard.
\end{abstract}




\section{INTRODUCTION}

Ground-water-level and ground-water-quality data are essential for water assessment and management. Ground-water-level fluctuations and trends can be used to estimate changes in aquifer storage resulting from the effects of ground-water withdrawal and precipitation. These data can be used to address water-management needs and to evaluate the effects of management and conservation programs.

As part of the ground-water investigations undertaken by the U.S. Geological Survey (USGS) in cooperation with the State of Georgia and city and county governments, a Statewide water-levelmeasurement program was started in 1938. At the onset, this program consisted of an observation-well network in the coastal area of Georgia to monitor variations in ground-water storage and quality. Additional wells were included in areas where the data could be used to predict potential water-resources problems.

During 1993, periodic water-level measurements were made in 302 wells, and continuous waterlevel measurements were obtained from an additional 156 wells. Continuous water-level records were obtained using analog (pen and chart) recorders, digital recorders that record water levels at 30-minute (min) or 60-min intervals, and electronic data recorders that record water levels at 60 -min intervals. At sites where records were missing, data were estimated, where possible, using historical data from the well and contemporaneous data from nearby wells that showed similar water-level fluctuations and trends. At sites where missing records could not be estimated and more than 20 percent of the data were missing , mean ground-water levels were not calculated. Water samples from 96 wells collected during April and October were analyzed during 1993 to determine chloride concentration in the Savannah and Brunswick areas.

\section{Purpose and Scope}

The purpose of this report is to present selected precipitation, ground-water-level, and water-quality data for Georgia for calendar year 1993. Graphs showing precipitation for 10 National Weather Service stations and for ground-water levels in 72 wells are presented. Graphs showing chloride concentrations of water from 13 wells tapping the Floridan aquifer system in the Savannah and Brunswick areas are included. The text includes a brief discussion of the aquifers and the aquifer systems, ground-water levels, and salinity. An extensive list of references are presented in "Selected References"; previously published reports in this series are listed in table 1.

\section{Well-Numbering System}

Wells described in this report are numbered according to a system based on the USGS index of topographic maps of Georgia. Each 7 1/2-minute topographic quadrangle in the State has been assigned a six-digit number and letter designation beginning at the southwestern corner of the State. Numbers increase sequentially eastward and letters advance alphabetically northward. Quadrangles in the northern part of the State are designated by double letters; AA follows Z, and so forth. The letters "I", "O", "II", and "OO" are not used. Wells inventoried in each quadrangle are numbered consecutively, beginning with 01 . Thus, the fourth well scheduled in the 11AA quadrangle is designated 11AA04. 
Table 1.--Previous Reports in this Series

[USGS, U.S. Geological Survey]

\begin{tabular}{cccc}
\hline $\begin{array}{c}\text { Year } \\
\text { of data } \\
\text { collection }\end{array}$ & $\begin{array}{c}\text { USGS } \\
\text { Open-File } \\
\text { Report number }\end{array}$ & \multicolumn{1}{c}{ Authors } & $\begin{array}{c}\text { Year } \\
\text { data } \\
\text { published }\end{array}$ \\
\hline 1977 & $79-213$ & \multicolumn{1}{c}{ None listed. } & 1978 \\
1978 & $79-1290$ & Clarke, J.S., Hester, W.G., and O'Byrne, M.P. & 1979 \\
1979 & $80-501$ & Mathews, S.E, Hester, W.G., and O'Byrne, M.P. & 1980 \\
1980 & $81-1068$ & Mathews, S.E., Hester, W.G., and O'Byrne, M.P. & 1981 \\
1981 & $82-904$ & Mathews, S.E., Hester, W.G., and McFadden, K.W. & 1982 \\
1982 & $83-678$ & Stiles, H.R., and Mathews, S.E. & 1983 \\
1983 & $84-605$ & Clarke, J.S., Peck, M.F., Longsworth, S.A., and McFadden, K.W. & 1984 \\
1984 & $85-331$ & Clarke, J.S., Longsworth, S.A., McFadden, K.W., and Peck, M.F. & 1985 \\
1985 & $86-304$ & Clarke, J.S., Joiner, C.N., Longsworth, S.A., McFadden, K.W., & 1986 \\
1986 & $87-376$ & and Peck, M.F. & 1987 \\
1987 & \multicolumn{4}{c}{ Clarke, J.S., Longsworth, S.A., Joiner, C.N., Peck, M.F., } & 1988 \\
1989 & $88-323$ & McFadden, K.W., and Milby, B.J. & 1989 \\
1989 & $89-408$ & Joiner, C.N., Reynolds, M.S., Stayton, W.L., and Boucher, F.G. & 1990 \\
1990 & $90-706$ & Joiner, C.N., Peck, M.F., Reynolds, M.S., and Stayton, W.L. & 1991 \\
1991 & $91-486$ & Peck, M.F., Joiner, C.N., Clarke, J.S., and Cressler, A.M. & 1992 \\
1992 & $92-470$ & Milby, B.J., Joiner, C.N., Cressler, A.M., and West, C.T. & 1993 \\
\hline & $93-358$ & Peck, M.F., Joiner, C.N., and Cressler, A.M. & \\
\hline
\end{tabular}

\section{PRECIPITATION}

Recharge to the ground-water system in Georgia is derived almost entirely from precipitation. Records for 1941-70 indicate that annual precipitation averaged 50 inches (in.) Statewide, and ranged from $44 \mathrm{in}$. in the east-central part to about $76 \mathrm{in}$. in the northeastern corner of the State (fig. 1). Of the total annual precipitation, about 88 percent is discharged to streams or is lost to evapotranspiration, and about 12 percent enters the ground-water system as recharge (Carter and Stiles, 1983).

Monthly mean precipitation data furnished by the National Oceanic and Atmospheric Administration (1993) are shown graphically for 10 precipitation stations (figs. 2-11). For each station, monthly precipitation was compared to the 30-year (yr) (1961-90) average (normal) for the station. Cumulative departure curves are a method often used to illustrate surplus or deficit amounts of precipitation over a designated time period. The curves used in this report were obtained by adding successive monthly values of precipitation departures from normal. Thus, the annual cumulative departure through December represents the sum of all monthly deficits or surpluses during the year. The 10-yr cumulative departure at the end of December represents the sum of all monthly deficits or surpluses for the previous 119 months. For each of the precipitation stations, the lower graph (figs. 2-11) shows the cumulative departure from normal precipitation for the period 1984-93; the upper graph shows the monthly departure and cumulative departure for 1993.

The annual cumulative departures of precipitation in 1993 for the 10 stations (figs. 2-11), ranged from 13.4 in. below normal to 4.8 in. above normal. For the 10 -yr period (1984-93), the cumulative departures of precipitation ranged from $47.0 \mathrm{in}$. below normal to $14.9 \mathrm{in}$. above normal. 


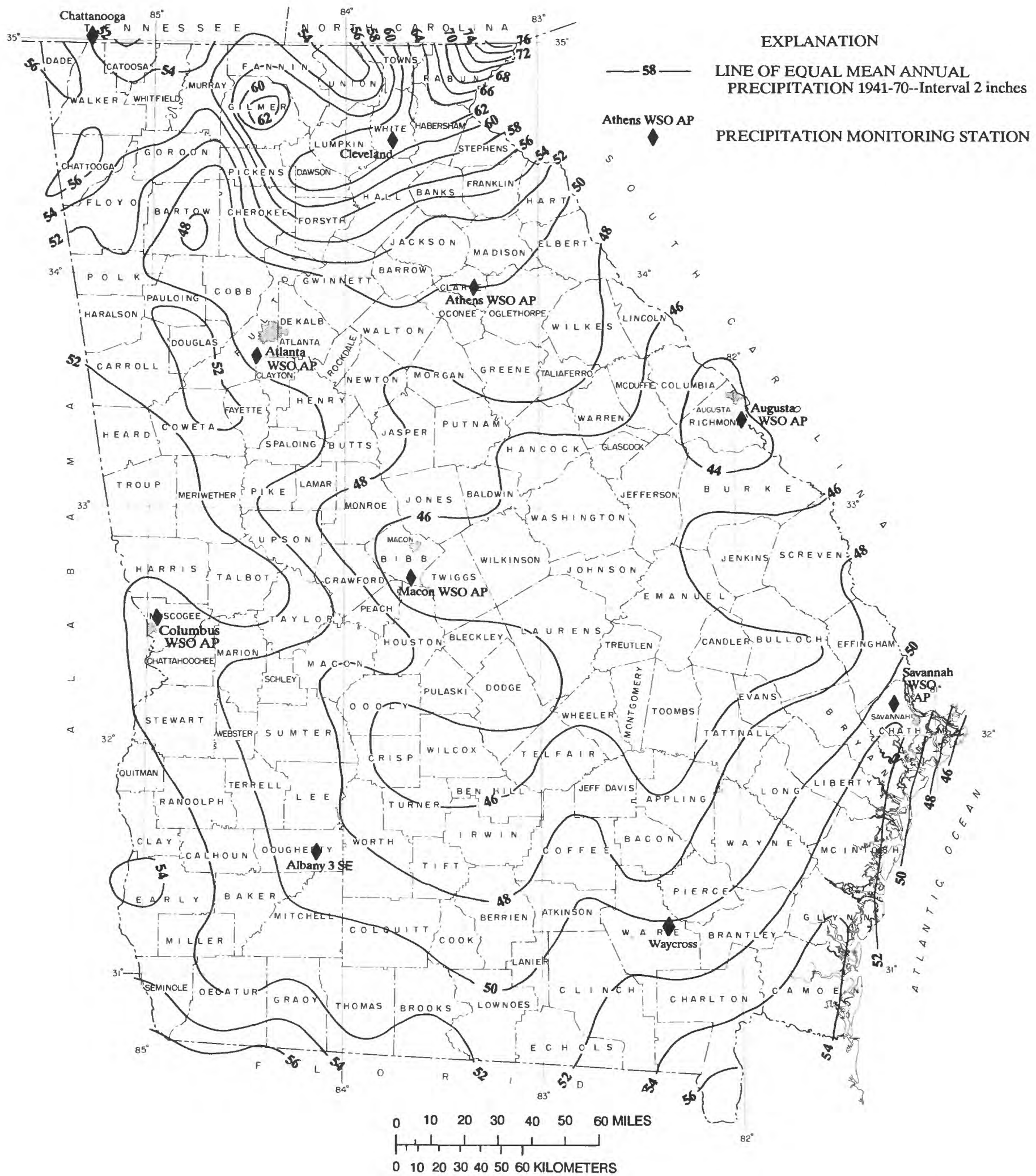

Figure 1.--Locations of precipitation monitoring stations and mean annual precipitation in Georgia, 1941-70. [Modified from Carter and Stiles (1983)] 

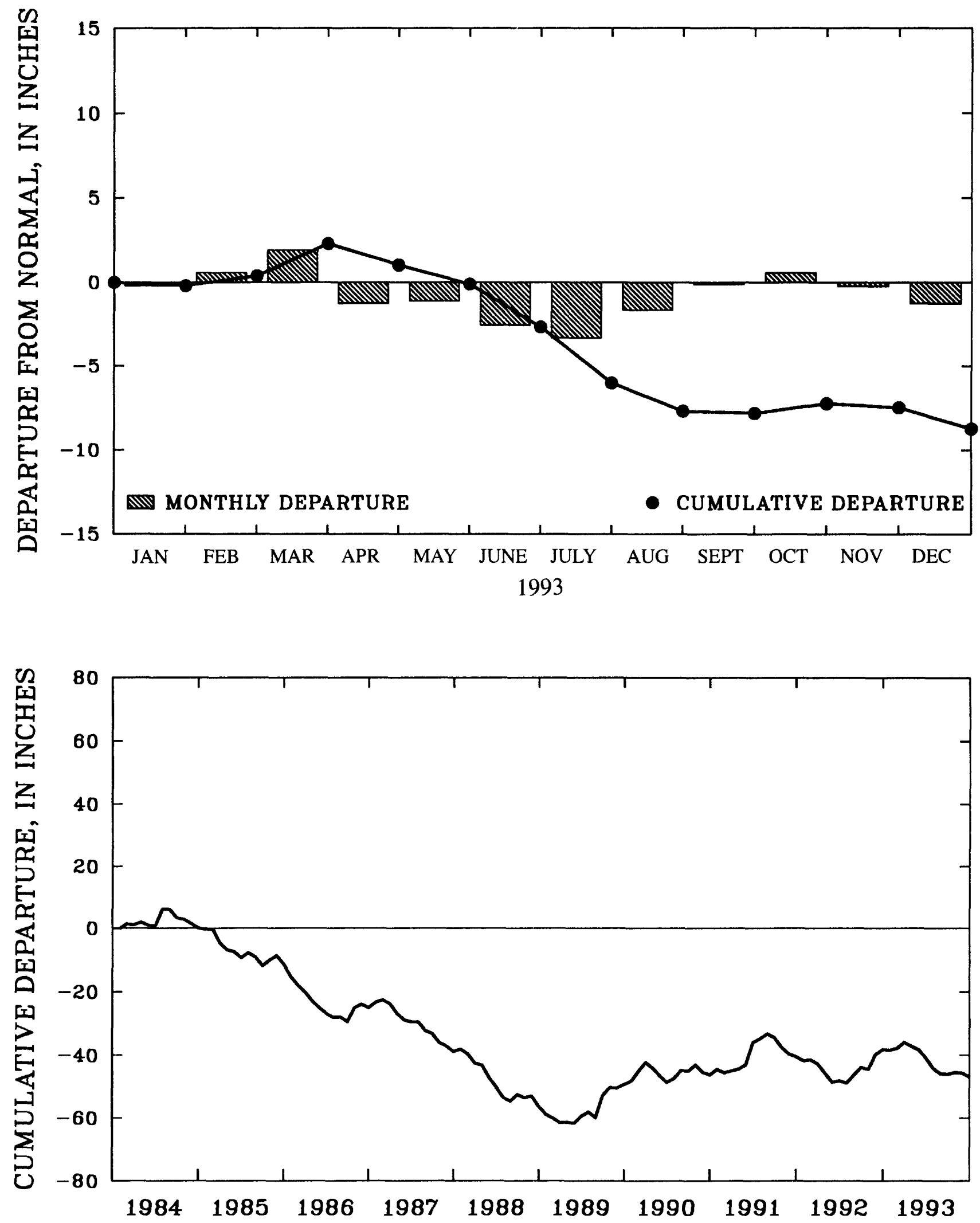

Figure 2. Cumulative monthly precipitation departure from long-term mean monthly precipitation (1961-90) and monthly departure and cumulative departure for 1993 for National Weather Service station at Athens airport, Clarke County, Georgia. 

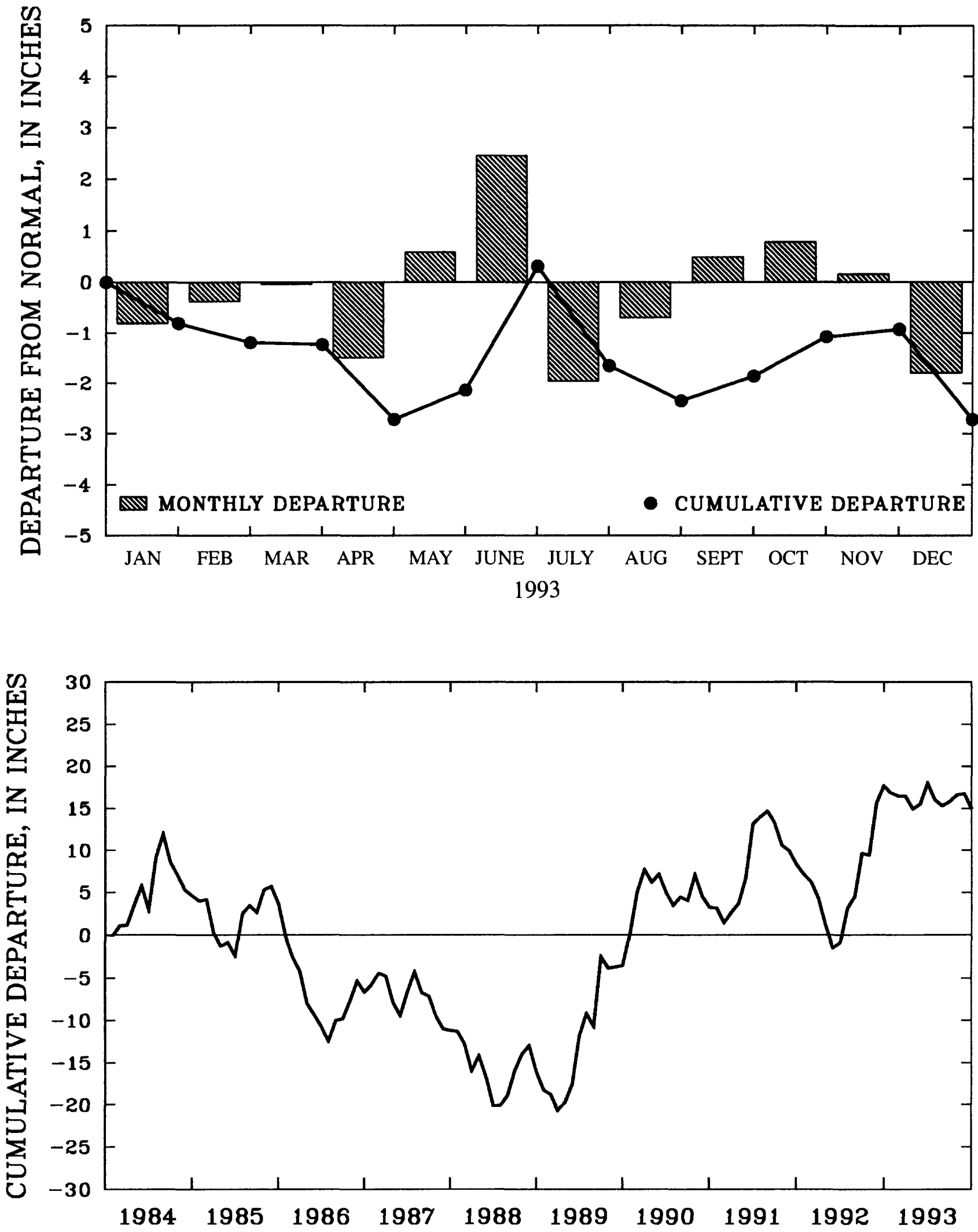

Figure 3. Cumulative monthly precipitation departure from long-term mean monthly precipitation (1961-90) and monthly departure and cumulative departure for 1993 for National Weather Service station at Atlanta airport, Fulton County, Georgia. 


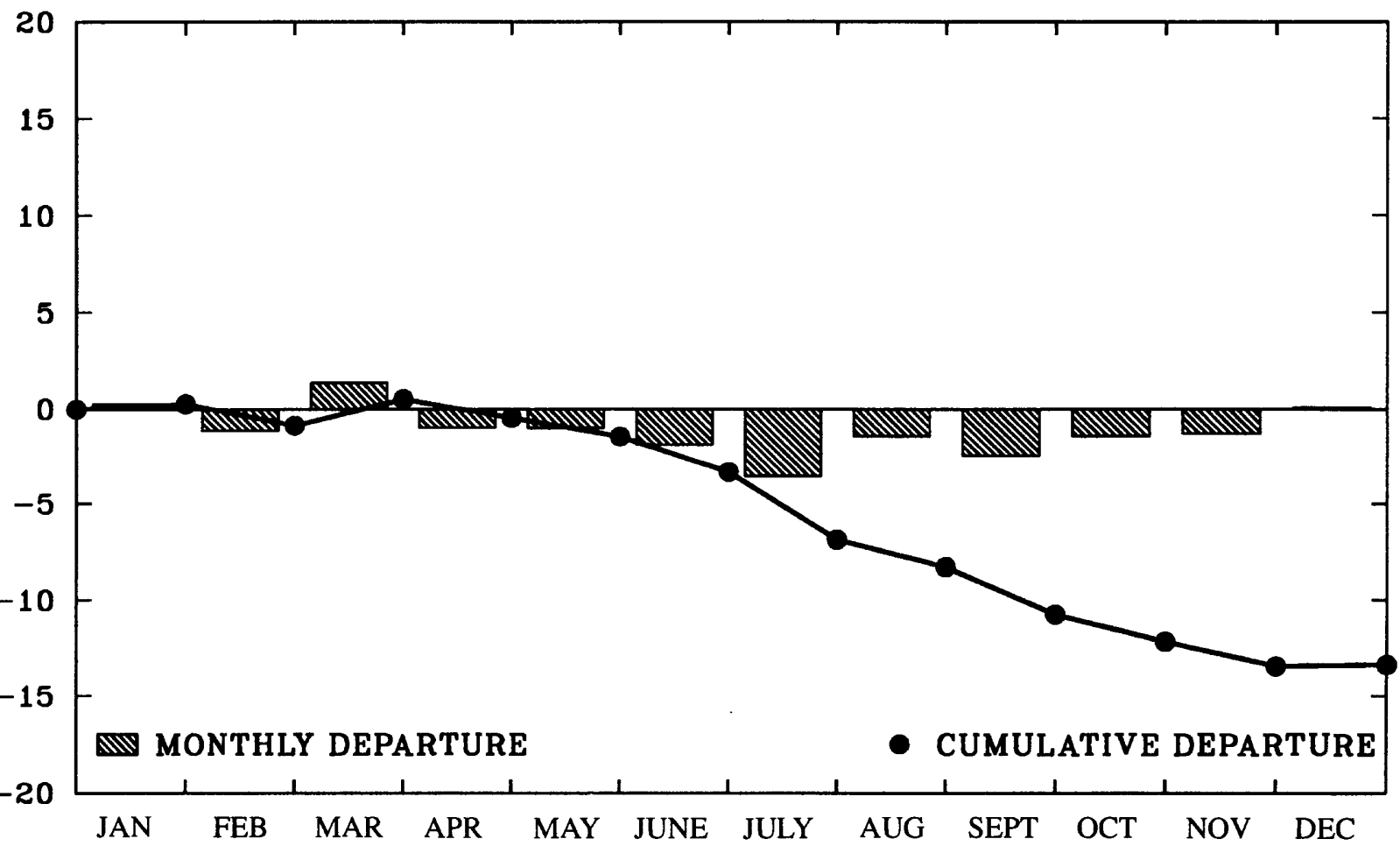

1993

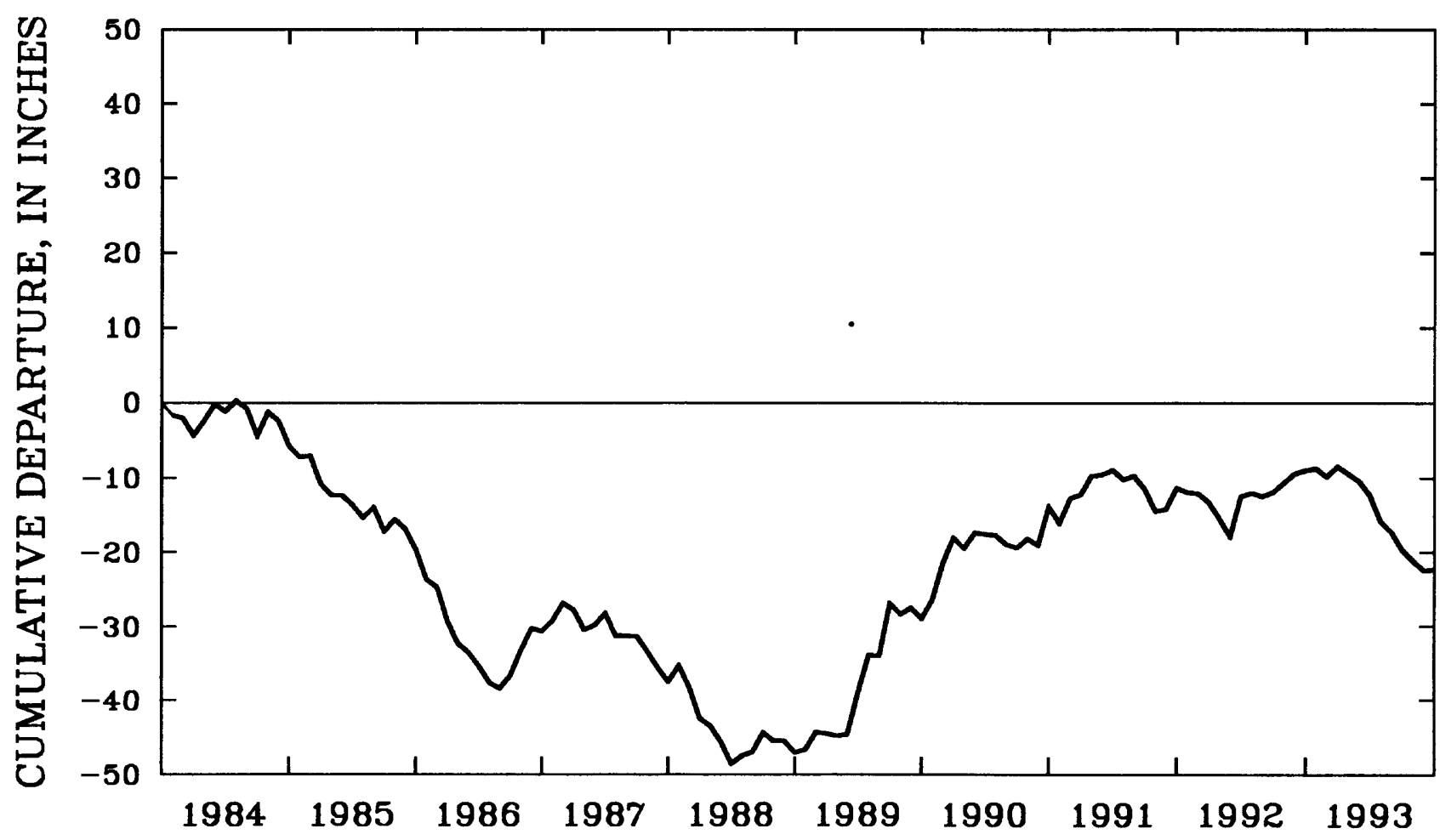

Figure 4. Cumulative monthly precipitation departure from long-term mean monthly precipitation (1961-90) and monthly departure and cumulative departure for 1993 for National Weather Service station at Chattanooga, airport, Hamilton County, Tennessee. 

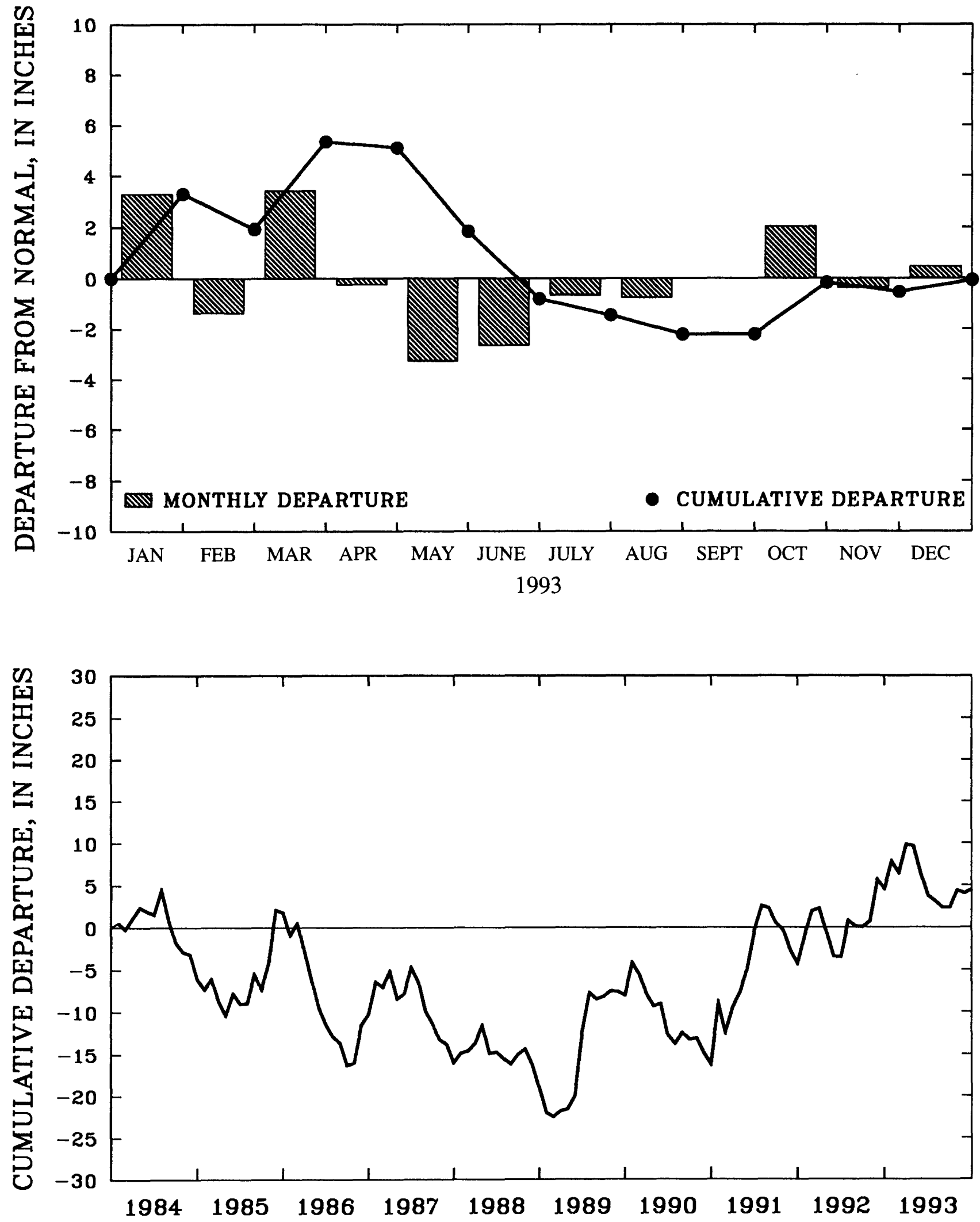

Figure 5. Cumulative monthly precipitation departure from long-term mean monthly precipitation (1961-90) and monthly departure and cumulative departure for 1993 for National Weather Service station at Albany 3SE, Dougherty County, Georgia. 

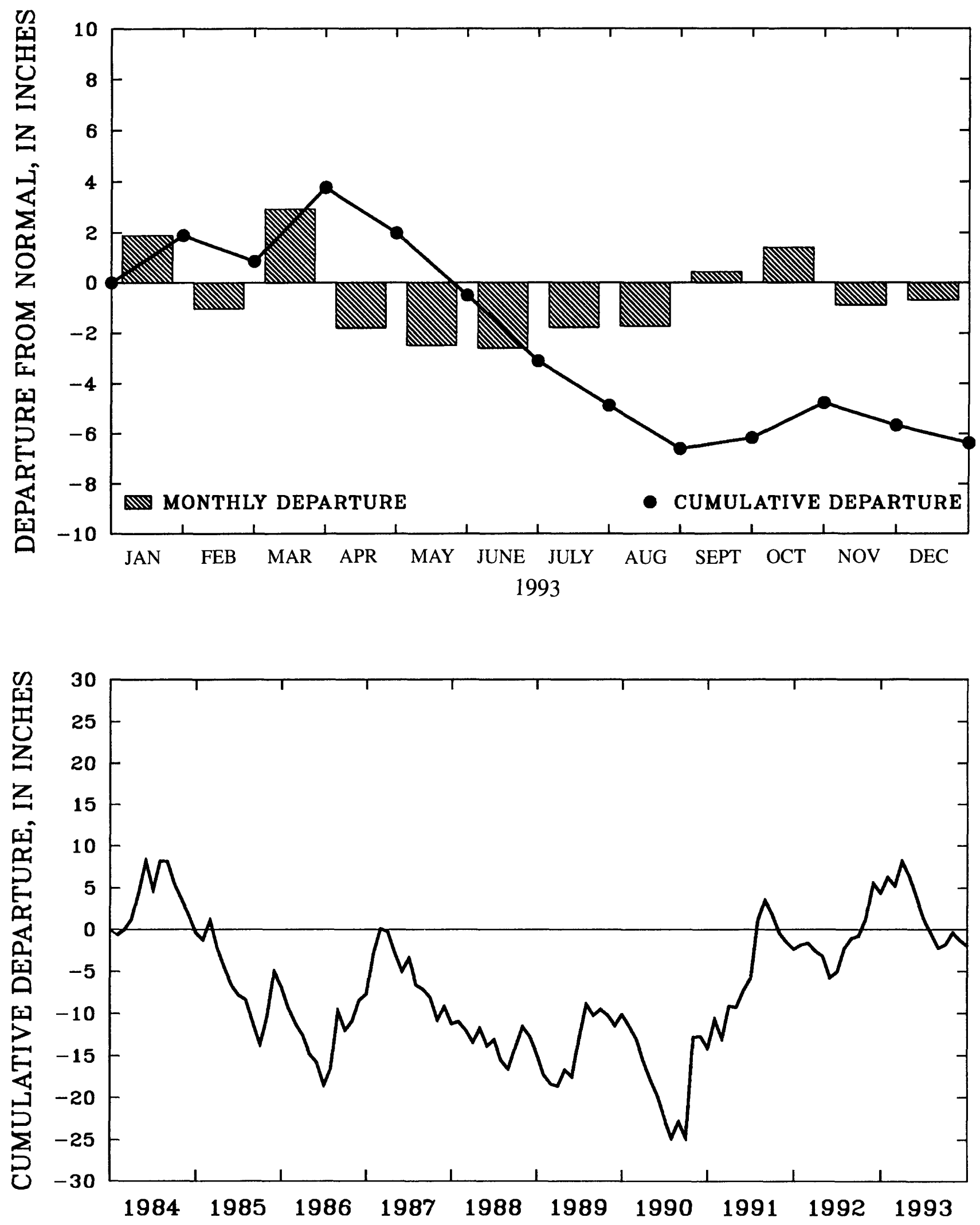

Figure 6. Cumulative monthly precipitation departure from long-term mean monthly precipitation (1961-90) and monthly departure and cumulative departure for 1993 for National Weather Service station at Augusta airport, Richmond County, Georgia. 

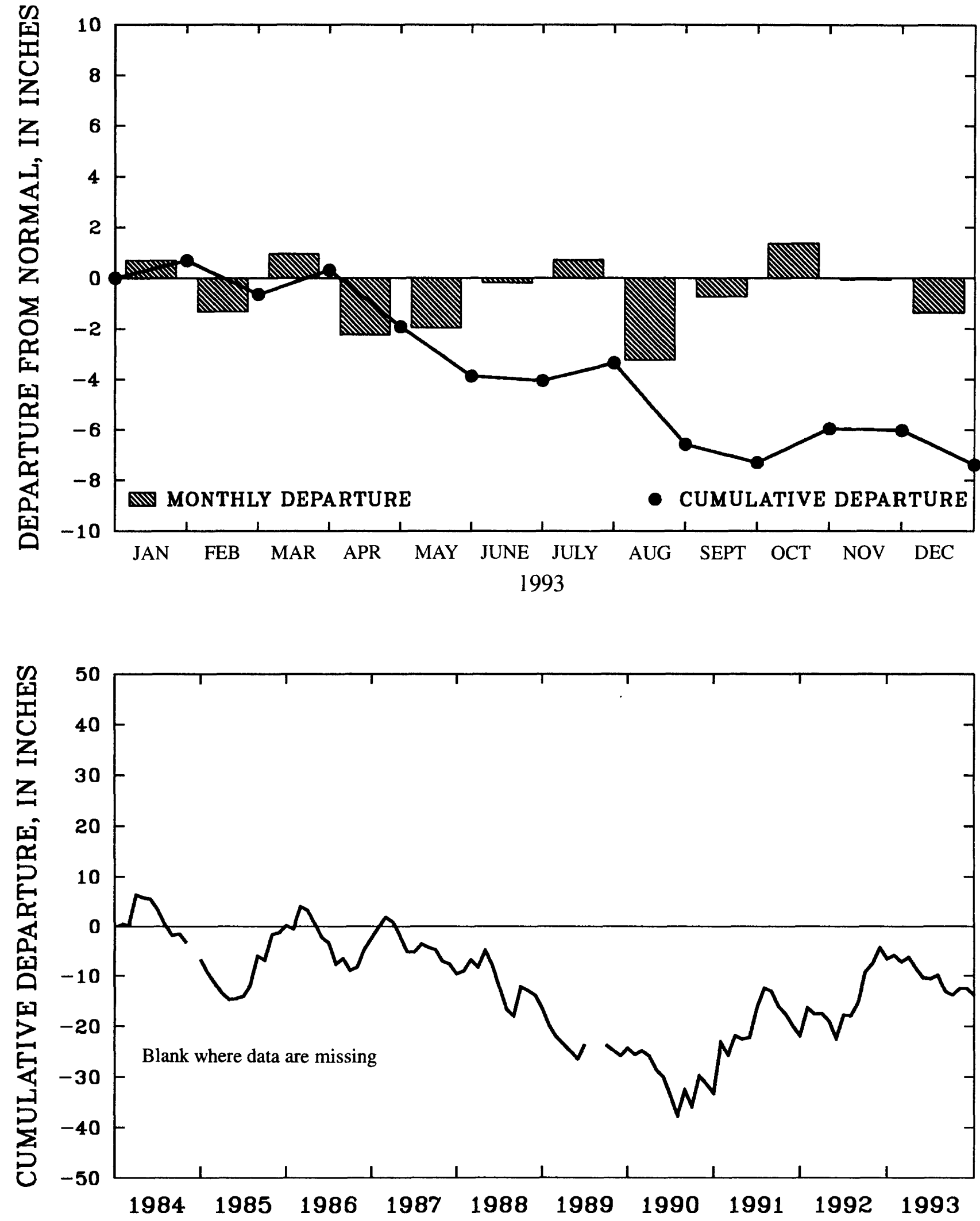

Figure 7. Cumulative monthly precipitation departure from long-term mean monthly precipitation (1961-90) and monthly departure and cumulative departure for 1993 for National Weather Service station at Waycross WSMO, Ware County, Georgia. 

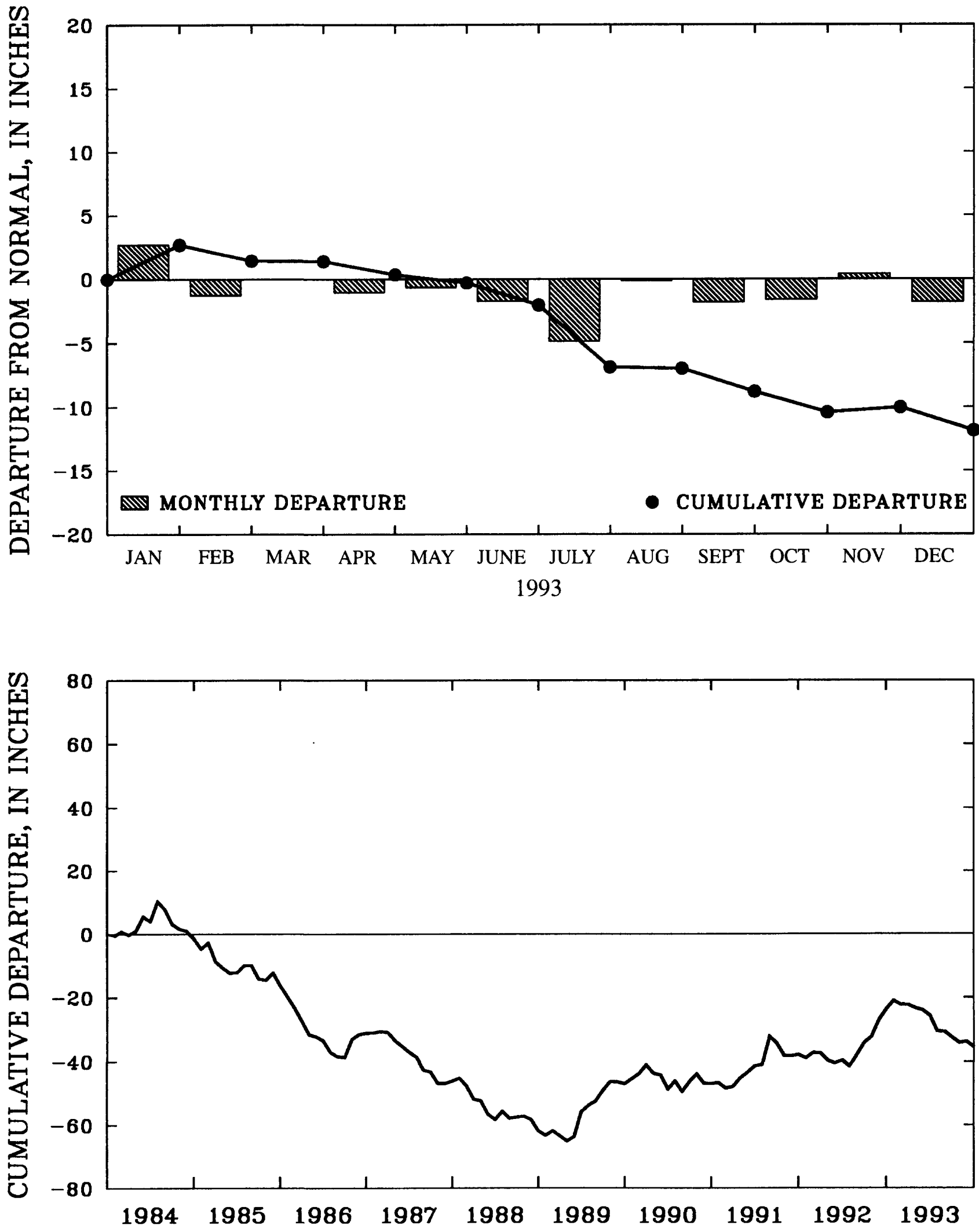

Figure 8. Cumulative monthly precipitation departure from long-term mean monthly precipitation (1961-90) and monthly departure and cumulative departure for 1993 for National Weather Service station at Cleveland, White County, Georgia. 

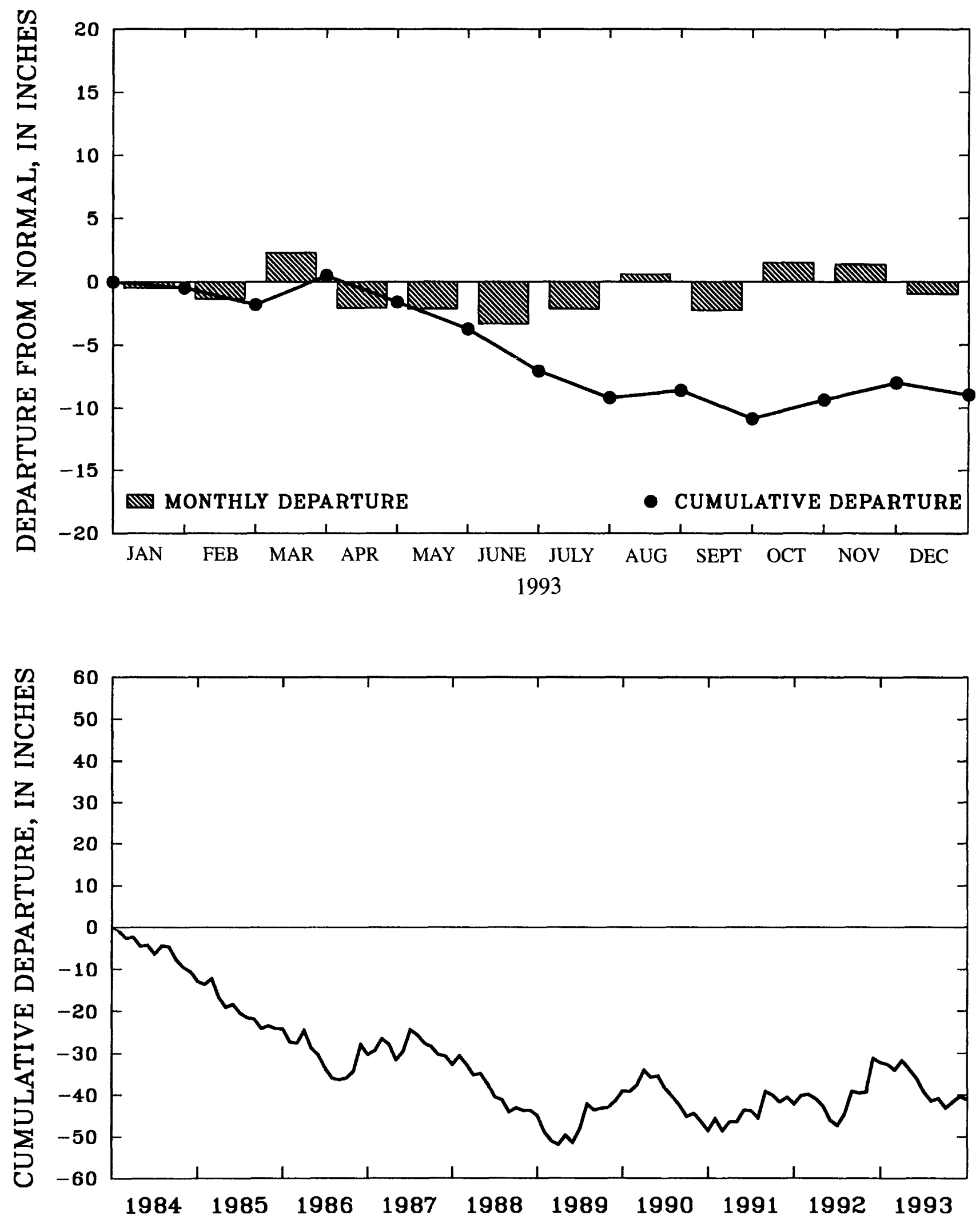

Figure 9. Cumulative monthly precipitation departure from long-term mean monthly precipitation (1961-90) and monthly departure and cumulative departure for 1993 for National Weather Service station at Columbus airport, Muscogee County, Georgia. 

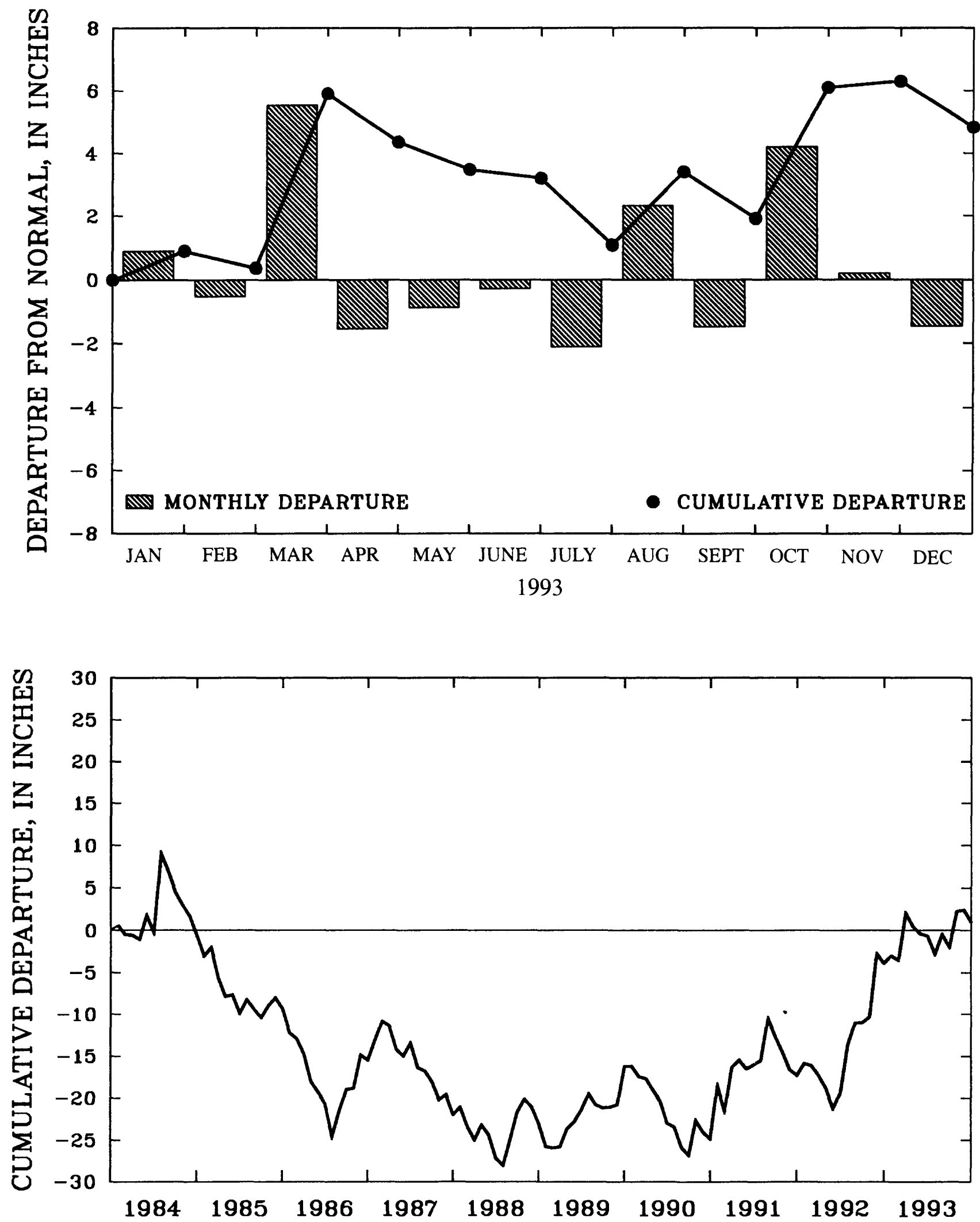

Figure 10. Cumulative monthly precipitation departure from long-term mean monthly precipitation (1961-90) and monthly departure and cumulative departure for 1993 for National Weather Service station at Macon airport, Bibb County, Georgia. 

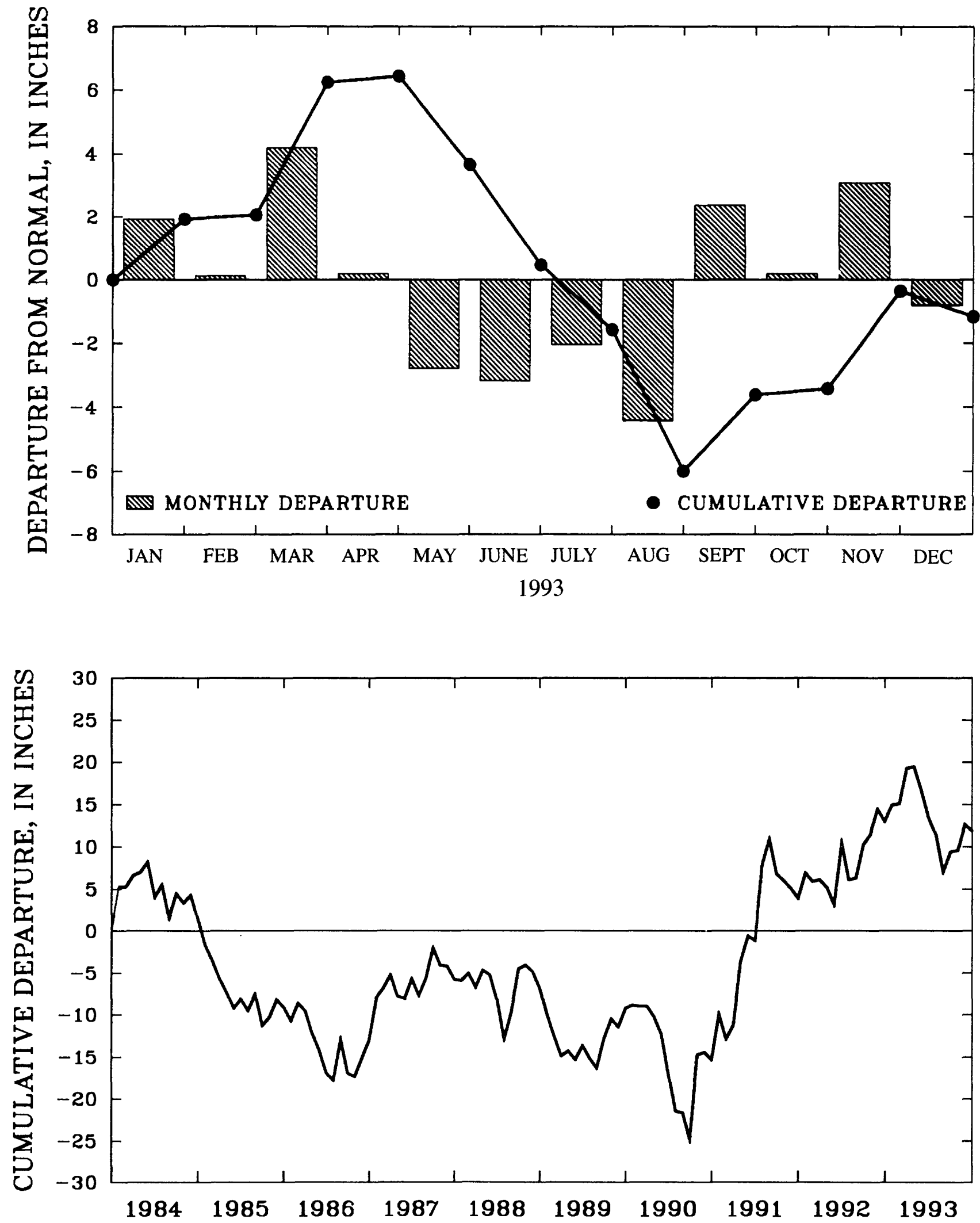

Figure 11. Cumulative monthly precipitation departure from long-term mean monthly precipitation (1961-90) and monthly departure and cumulative departure for 1993 for National Weather Service station at Savannah airport, Chatham County, Georgia. 


\section{GROUND-WATER RESOURCES}

Contrasting geologic features and landforms of the physiographic provinces of Georgia (table 2, fig. 12) result in substantial differences in ground-water conditions from one part of the State to another. These features that make up the framework of the aquifers affect the quantity and quality of the ground water throughout the State.

Surficial aquifers are present in each of the physiographic provinces. In the Piedmont, Blue Ridge, and Valley and Ridge Provinces (fig. 12), the surficial aquifers consist of soil, saprolite, stream alluvium, colluvium, and other surficial deposits. In the Coastal Plain Province, the surficial aquifers consist of intermixed layers of sand, clay, and limestone. The surficial aquifers usually are under water-table (unconfined) conditions and are used for domestic and livestock supplies. These aquifers can be semiconfined locally in the coastal area.

In the Piedmont and Blue Ridge Provinces, ground water is transmitted through secondary openings along fractures, foliation, joints, contacts, or other features in the crystalline bedrock. Rocks in these provinces are complex and consist of structurally deformed metamorphic and igneous rocks. In the Valley and Ridge Province, ground water is transmitted through both primary and secondary openings in folded and faulted sedimentary and meta-sedimentary rocks.

The most productive aquifers in Georgia are in the Coastal Plain Province in the southern part of the State. The Coastal Plain is underlain by alternating layers of sand, clay, and limestone that dip and thicken to the southeast. In the Coastal Plain, aquifers generally are confined, except near their northern limits where they crop out or are near land surface. The aquifers of the Coastal Plain include surficial aquifers, the upper Brunswick aquifer, the lower Brunswick aquifer, the Floridan aquifer system, the Claiborne aquifer, the Clayton aquifer, and the Cretaceous aquifers and aquifer systems. 
Table 2.--Aquifer and well characteristics in Georgia

[Modified from Clarke and Pierce (1984) and Peck and others (1992); ft, feet; gal/min, gallons per minute]

\begin{tabular}{|c|c|c|c|c|}
\hline \multirow[b]{3}{*}{$\begin{array}{l}\text { Aquifer name } \\
\text { and description }\end{array}$} & \multicolumn{3}{|c|}{ Well characteristics } & \multirow[b]{3}{*}{ Remarks } \\
\hline & \multirow{2}{*}{$\begin{array}{c}\text { Depth }(\mathrm{ft}) \\
\begin{array}{c}\text { Common } \\
\text { range }\end{array}\end{array}$} & \multicolumn{2}{|c|}{ Yield (gal/min) } & \\
\hline & & $\begin{array}{l}\text { Common } \\
\text { range }\end{array}$ & $\begin{array}{l}\text { May } \\
\text { exceed }\end{array}$ & \\
\hline $\begin{array}{l}\text { Surficial aquifers: } \\
\text { Unconsolidated sediments. } \\
\text { Generally unconfined. }\end{array}$ & $11-72$ & $2-25$ & 25 & $\begin{array}{l}\text { Primary source of water for domestic and } \\
\text { livestock supply in rural areas. Supplemental } \\
\text { source of water in coastal Georgia. }\end{array}$ \\
\hline $\begin{array}{l}\text { Upper and Lower Brunswick } \\
\text { aquifers: } \\
\text { Phosphatic and dolomitic } \\
\text { quartz sand. Generally } \\
\text { confined. }\end{array}$ & $85-390$ & $10-30$ & 180 & $\begin{array}{l}\text { Not a major source of water in coastal Georgia, } \\
\text { but considered a supplemental water supply to the } \\
\text { Upper Floridan aquifer. Most wells are multi- } \\
\text { aquifer, tapping the upper and lower Brunswick } \\
\text { aquifers and the Upper Floridan aquifer. The } \\
\text { lower Brunswick aquifer currently is not } \\
\text { monitored (see Clarke and others, 1990, p. 26-28). }\end{array}$ \\
\hline $\begin{array}{l}\text { Floridan aquifer system: } \\
\text { Limestone, dolomite, and } \\
\text { calcareous sand. Generally } \\
\text { confined. }\end{array}$ & $40-900$ & $1,000-5,000$ & 11,000 & $\begin{array}{l}\text { Supplies } 50 \text { percent of ground water in Georgia. } \\
\text { The aquifer system is divided into the Upper and } \\
\text { Lower Floridan aquifers. In the Brunswick area, } \\
\text { the Upper Floridan aquifer includes two } \\
\text { freshwater-bearing zones, the upper water- } \\
\text { bearing zone and the lower water-bearing zone. } \\
\text { The Lower Floridan aquifer is not considered a } \\
\text { major aquifer. In the Brunswick area and } \\
\text { southeastern Georgia, the Lower Floridan aquifer } \\
\text { includes the Fernandina permeable zone (Krause } \\
\text { and Randolph,I989). }\end{array}$ \\
\hline $\begin{array}{l}\text { Claiborne aquifer: } \\
\text { Sand and sandy limestone. } \\
\text { Generally confined }\end{array}$ & $20-450$ & $150-600$ & 1,500 & $\begin{array}{l}\text { Major source of water in southwestern Georgia } \\
\text { for irrigation, industrial, and municipal use. }\end{array}$ \\
\hline $\begin{array}{l}\text { Clayton aquifer: } \\
\text { Limestone and sand. } \\
\text { Generally confined }\end{array}$ & $40-800$ & $250-600$ & 2,150 & $\begin{array}{l}\text { Major source of water in southwestern Georgia } \\
\text { for irrigation, industrial, and municipal use. }\end{array}$ \\
\hline $\begin{array}{l}\text { Cretaceous aquifers and } \\
\text { aquifer systems: } \\
\text { Sand and gravel. } \\
\text { Generally confined }\end{array}$ & $30-750$ & $50-1,200$ & 3,300 & $\begin{array}{l}\text { Major source of water in east-central Georgia. } \\
\text { Supplies water for kaolin mining and processing. } \\
\text { Includes the Providence aquifer in southwestern } \\
\text { Georgia, and the Dublin, Midville, and Dublin- } \\
\text { Midville aquifer systems in east-central Georgia. }\end{array}$ \\
\hline $\begin{array}{l}\text { Paleozoic rock aquifers: } \\
\text { Sandstone, limestone, and } \\
\text { dolostone. }\end{array}$ & $15-2,100$ & $1-50$ & 3,500 & $\begin{array}{l}\text { Not laterally extensive. Limestone and dolostone } \\
\text { aquifers are most productive. Storage is in } \\
\text { regolith, primary openings, and secondary } \\
\text { fractures and solution openings in rock. Springs in } \\
\text { limestone and dolostone aquifers discharge at } \\
\text { rates of as much as } 5,000 \text { gal/min. Sinkholes may } \\
\text { form in areas of intensive pumping. }\end{array}$ \\
\hline $\begin{array}{l}\text { Crystalline-rock aquifers: } \\
\text { Granite, gneiss, schist, and } \\
\text { quartzite }\end{array}$ & $40-600$ & 1.25 & 500 & $\begin{array}{l}\text { Not laterally extensive. Storage is in regolith and } \\
\text { fractures in rock. Hydrogeology of crystalline } \\
\text { rock aquifers is not well understood. }\end{array}$ \\
\hline
\end{tabular}



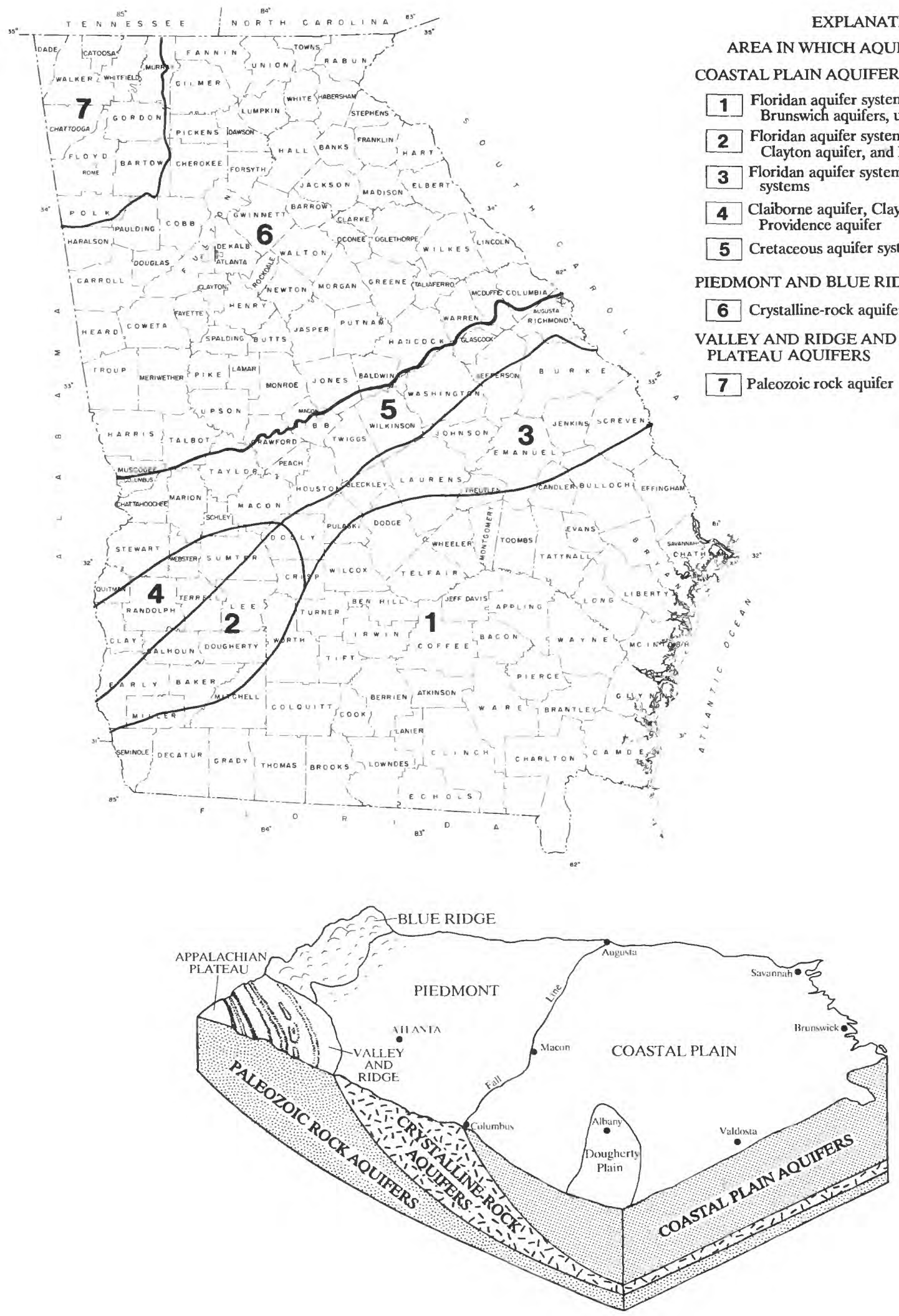

Figure 12.--Areas of utilization of major aquifers and block diagram showing major aquifers and physiographic provinces of Georgia. [Modified from Peck and others, 1992] 


\section{GROUND-WATER LEVELS}

Fluctuations and long-term trends in ground-water levels are a result of variations in recharge and discharge. Recharge varies in response to precipitation and surface-water infiltration into the aquifer. Discharge occurs as natural flow from the aquifer to streams and springs, as evapotranspiration, and as withdrawal from wells.

Water-level fluctuations in 72 wells continuously monitored in 1993 (table 3, fig. 13) are considered to be representative of ground-water conditions throughout the State. Discussions of the ground-water conditions shown in these hydrographs were grouped by aquifer and subdivided into areas and subareas in which wells had similar water-level fluctuations and trends.

For each well, daily mean water levels are shown in hydrographs for 1993, and monthly mean water levels are shown in hydrographs for the period of record. A summary of monthly and annual mean waterlevel statistics for 1993 is included with each hydrograph. The text accompanying each section discusses the range in 1993 annual mean water levels for each section compared to the 1992 annual mean water level (Peck and others, 1993) and the occurrence of record-low or record-high water levels in 1993. In this report, a record water level refers to the lowest or highest daily mean water level for the period of record of a particular well. Thus, any instantaneous water-level measurement on a given day may be lower or higher than the record water level mentioned in the text, the minimum or maximum value in the statistics, or the daily mean water level shown on the hydrograph. In discussions of differences in annual, monthly, or daily mean water levels, the terms "slightly" and "about the same" are used for differences less than or equal to $0.1 \mathrm{ft}$.

Continuous records from the 72 wells in 1993 indicate that annual mean ground-water levels were from about $3.2 \mathrm{ft}$ higher to about $9.6 \mathrm{ft}$ lower than in 1992. The annual mean water level was higher in 30 wells and lower in 42 wells. Record-high daily mean water levels that were from about 0.1 to about $0.7 \mathrm{ft}$ higher than the previous highs were recorded in four wells; one tapping the surficial aquifer, one tapping the Upper Floridan aquifer, one tapping the Claiborne aquifer, and one tapping the crystalline-rock aquifers. Record-low daily mean water levels that were from about $0.1 \mathrm{ft}$ to about $7.2 \mathrm{ft}$ lower than the previous record lows were measured in ten wells; one tapping the surficial aquifer, two tapping the Upper Floridan aquifer, four tapping the Clayton aquifer, one tapping the Cretaceous aquifer, one tapping the Dublin-Midville aquifer system, and one tapping the crystalline-rock aquifers.

Table 3.--Observation wells for which hydrographs are included in this report

\begin{tabular}{|c|c|c|c|c|}
\hline County & Aquifer & $\begin{array}{c}\text { Well } \\
\text { number }\end{array}$ & Well name & Page \\
\hline Bulloch & Upper Floridan & $32 \mathrm{R} 002$ & Bulloch South test well 1 & 64 \\
\hline Bulloch & Surficial & $32 \mathrm{R} 003$ & Bulloch South test well 2 & 29 \\
\hline Bulloch & Upper Brunswick & $31 \mathrm{U} 009$ & Hopeulikit test well 2 & 34 \\
\hline Burke & Midville aquifer system & $28 \times 001$ & Midville Experimental Station & 111 \\
\hline Camden & Upper Floridan & $33 \mathrm{E} 027$ & Kings Bay & 77 \\
\hline Charlton & Upper Floridan & 27E004 & Test well OK9 & 78 \\
\hline Chatham & Surficial & $35 \mathrm{P} 094$ & UGA & 27 \\
\hline Chatham & Upper Floridan & $36 \mathrm{Q} 008$ & Layne-Atlantic & 60 \\
\hline Chatham & Upper Floridan & $36 \mathrm{Q} 020$ & Morrison & 61 \\
\hline Chatham & Surficial & $37 \mathrm{P} 116$ & Skidaway Institute test well 4 & 28 \\
\hline Chatham & Upper Floridan & 38Q002 & Pilot House & 62 \\
\hline Chatham & Upper Floridan & 390003 & Test well 7 , point 3 & 63 \\
\hline Chattahoochee & Cretaceous age formations & $06 S 001$ & Fort Benning & 104 \\
\hline Cook & Upper Floridan & $18 \mathrm{H} 016$ & Adel & 50 \\
\hline Crisp & Clayton & $14 \mathrm{P} 014$ & Georgia Veterans Memorial State Park test well 1 & 101 \\
\hline Crisp & Claiborne & $14 \mathrm{P} 015$ & Georgia Veterans Memorial State Park test well 2 & 92 \\
\hline Decatur & Upper Floridan & 09F520 & Bolton & 40 \\
\hline DeKalb & Crystalline rock & $11 \mathrm{FF} 04$ & GAR, test well 5 & 122 \\
\hline Dougherty & Providence & 12L021 & Test well 10 & 106 \\
\hline Dougherty & Claiborne & $11 \mathrm{~K} 002$ & Test well 11 & 87 \\
\hline
\end{tabular}


Table 3.--Observation wells for which hydrographs are included in this report--Continued

\begin{tabular}{|c|c|c|c|c|}
\hline County & Aquifer & $\begin{array}{c}\text { Well } \\
\text { number }\end{array}$ & Well name & Page \\
\hline Dougherty & Clayton & $11 \mathrm{~K} 005$ & Test well 12 & 100 \\
\hline Dougherty & Clayton & $11 \mathrm{~L} 002$ & Albany Nursery & 98 \\
\hline Dougherty & Clayton & $13 \mathrm{~L} 002$ & Turner City & 99 \\
\hline Dougherty & Claiborne & $11 \mathrm{~L} 001$ & Test well 4 & 88 \\
\hline Dougherty & Claiborne & 12L019 & Test well 5 & 89 \\
\hline Dougherty & Claiborne & 13L011 & Test well 2 & 90 \\
\hline Dougherty & Upper Floridan & $13 \mathrm{~L} 003$ & Albany-Dougherty County & 45 \\
\hline Dougherty & Upper Floridan & $13 \mathrm{~L} 012$ & Test well 3 & 43 \\
\hline Early & Clayton & $06 \mathrm{~K} 009$ & Kolomoki State Park test well 1 & 95 \\
\hline Early & Claiborne & $06 \mathrm{~K} 010$ & Kolomoki State Park test well 2 & 85 \\
\hline Fulton & Crystalline rock & 10DD02 & Fort McPherson & 120 \\
\hline Glynn & Upper Floridan & $33 \mathrm{H} 127$ & Test well 3 & 72 \\
\hline Glynn & Upper Floridan & $33 \mathrm{H} 133$ & Test well 6 & 74 \\
\hline Glynn & Lower Floridan & 33J044 & Test well 27 & 82 \\
\hline Glynn & Upper Floridan & $34 \mathrm{H} 371$ & Test well 11 & 75 \\
\hline Glynn & Lower Floridan & $34 \mathrm{H} 391$ & Test well 16 & 81 \\
\hline Glynn & Upper Floridan & $34 \mathrm{H} 403$ & Test well 24 & 73 \\
\hline Glynn & Upper Brunswick & $34 \mathrm{H} 437$ & Coffin Park test well 2 & 36 \\
\hline Glynn & Surficial & $34 \mathrm{H} 438$ & Coffin Park test well 3 & 30 \\
\hline Greene & Crystalline rock & $21 \mathrm{BB} 04$ & Veazey & 123 \\
\hline Laurens & Upper Floridan & $21 \mathrm{~T} 001$ & Hogan & 54 \\
\hline Liberty & Upper Floridan & 34 N089 & Test well 1 & 65 \\
\hline Long & Upper Floridan & $33 \mathrm{M} 004$ & Test well 3 & 70 \\
\hline Lowndes & Upper Floridan & 19E009 & Valdosta & 51 \\
\hline Lowndes & Upper Floridan & 19F039 & Valdosta 8 & 52 \\
\hline Madison & Crystalline rock & $19 \mathrm{HH} 12$ & Meadowlake Estates & 121 \\
\hline McIntosh & Upper Floridan & $35 \mathrm{M} 013$ & Harris Neck & 66 \\
\hline Miller & Surficial & $07 \mathrm{H} 003$ & DP-3 & 25 \\
\hline Miller & Upper Floridan & $08 \mathrm{G} 001$ & Viercocken & 41 \\
\hline Mitchell & Upper Floridan & $10 \mathrm{G} 313$ & Meinders & 44 \\
\hline Mitchell & Upper Floridan & 13J004 & Wright & 46 \\
\hline Montgomery & Upper Floridan & 25Q001 & Uvalda School & 55 \\
\hline Pulaski & Midville aquifer system & $18 \mathrm{~T} 001$ & Arrowhead test well 1 & 110 \\
\hline Randolph & Clayton & 07N001 & Cuthbert & 96 \\
\hline Randolph & Claiborne & 09M009 & Martin test well 1 & 86 \\
\hline Richmond & Dublin-Midville aquifer system & 30AA04 & McBean 2 & 113 \\
\hline Seminole & Upper Floridan & 06F001 & Roddenberry Farms test well 1 & 42 \\
\hline Spalding & Surficial & $11 \mathrm{AA} 01$ & UGA Experiment Station & 23 \\
\hline Terrell & Clayton & 09N001 & Graves School & 97 \\
\hline Tift & Upper Floridan & $18 \mathrm{~K} 049$ & Test well 1 & 49 \\
\hline Toombs & Upper Floridan & 26R001 & Vidalia 2 & 56 \\
\hline Twiggs & Dublin aquifer system & $18 \mathrm{U} 001$ & Test well 3 & 108 \\
\hline Walker & Paleozoic rock & 03PP01 & Chickamauga Battlefield & 117 \\
\hline Washington & Dublin-Midville aquifer system & $23 \times 027$ & Sandersville 8 & 114 \\
\hline Wayne & Upper Floridan & $30 \mathrm{~L} 003$ & Johnson & 68 \\
\hline Wayne & Upper Floridan & $32 \mathrm{~L} 015$ & Gardi test well 1 & 69 \\
\hline Wayne & Upper Brunswick & $32 \mathrm{~L} 016$ & Gardi test well 2 & 35 \\
\hline Wayne & Surficial & $32 \mathrm{~L} 017$ & Gardi test well 3 & 31 \\
\hline White & Crystalline rock & $16 \mathrm{MM} 03$ & Unicoi State Park No. 4 & 124 \\
\hline Worth & Claiborne & $13 \mathrm{M} 005$ & DP-7 & 91 \\
\hline Worth & Surficial & $13 \mathrm{M} 007$ & DP-9 & 24 \\
\hline Worth & Upper Floridan & $15 \mathrm{~L} 020$ & Sylvester & 47 \\
\hline
\end{tabular}




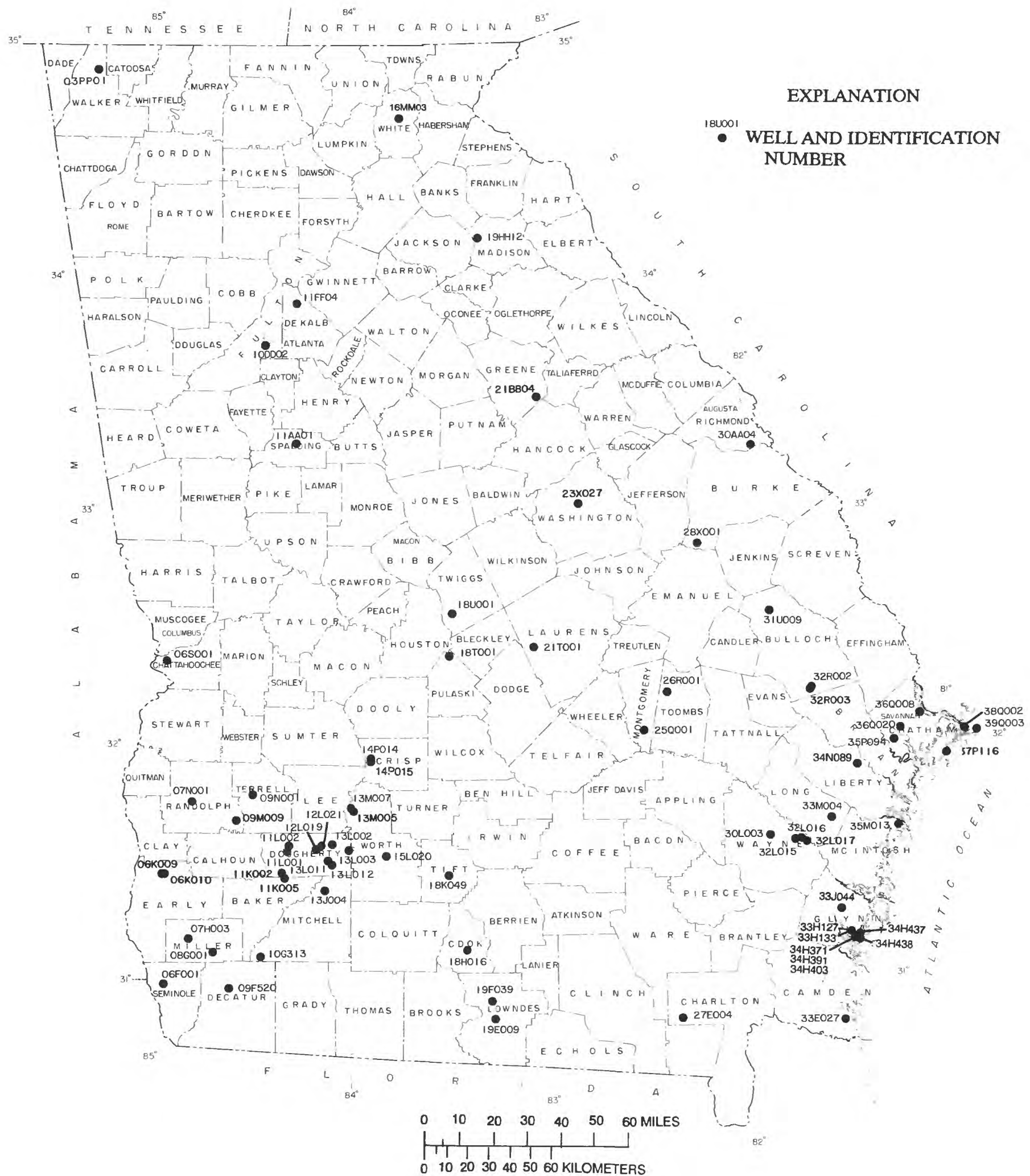

Figure 13.--Locations of observation wells for which hydrographs are included in this report. 


\section{Surficial Aquifers}

Water-level fluctuations in surficial aquifers were monitored in 15 wells in 1993; data from eight of these wells (fig. 14) are summarized in this report. Water-level fluctuations in surficial aquifers mainly were caused by variations in precipitation, evapotranspiration, and natural drainage. Water levels in surficial aquifers generally rise rapidly during wet periods and decline slowly during dry periods. Prolonged droughts may cause water levels to decline below pump intakes in shallow wells, particularly those located on hilltops and steep slopes, resulting in temporary well failures. Usually, well yields are restored with an increase in precipitation.

\section{Northern area}

Water-levels in the surficial aquifers in the northern part of Georgia were monitored in two wells in 1993. A summary of the data for one of these wells, 11AA01, at Griffin, Spalding County, is shown in figure 15. The annual mean water level in well 11AA01 was about $1.4 \mathrm{ft}$ higher in 1993 than in 1992.

\section{Southwestern area}

Water levels were monitored in seven wells that tap the surficial aquifer in the southwestern area in 1993. Data for two of the wells are shown in figures 16 and 17. The annual mean water level in these wells ranged from about 0.4 to $1.0 \mathrm{ft}$ lower in 1993 than in 1992. 


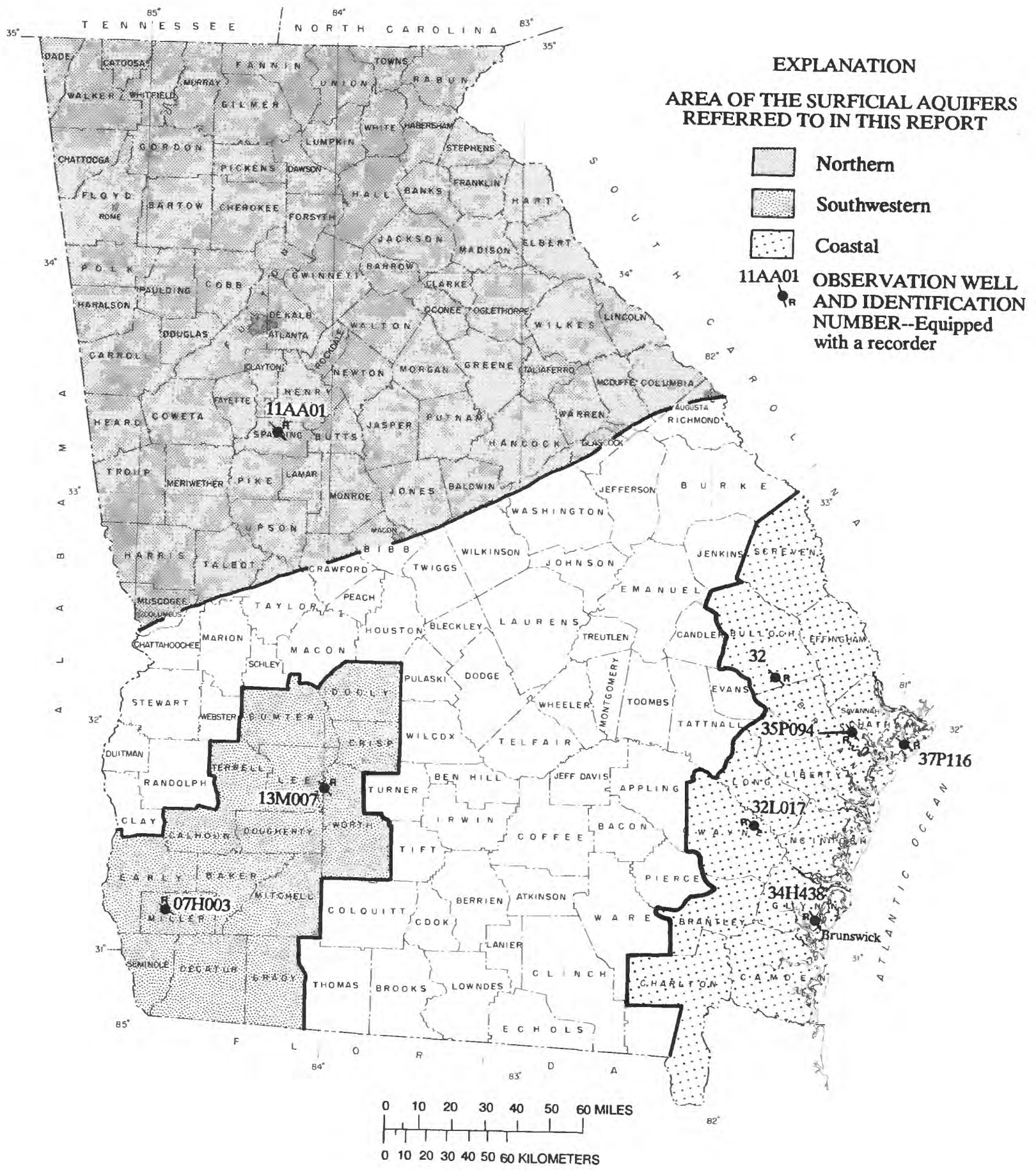

Figure 14.--Locations of observation wells completed in the surficial aquifers. 
331507084171801 Local number, 11AA01.

LOCATION.--Lat $33^{\circ} 15^{\prime} 54^{\prime \prime}$, long $84^{\circ} 16^{\prime} 56^{\prime \prime}$, Hydrologic Unit 03070103.

Owner: University of Georgia.

INSTRUMENTATION.--Digital recorder.

AQUIFER.--Surficial (residuum).

WELL CHARACTERISTICS.--Dug unused supply well, size 4 x $4 \mathrm{ft}$, depth $30 \mathrm{ft}$, cased to $30 \mathrm{ft}$, open end.

DATUM.--Altitude of land-surface datum is $950 \mathrm{ft}$.

REMARKS.--Water levels for period of missing record, February 18 to March 25, were estimated.

PERIOD OF RECORD.-October 1943 to current year.

EXTREMES FOR PERIOD OF RECORD.--Highest water level, $8.26 \mathrm{ft}$ below land-surface datum, March 19, 1948; lowest,

$21.82 \mathrm{ft}$ below land-surface datum, November 18-19, 1986.
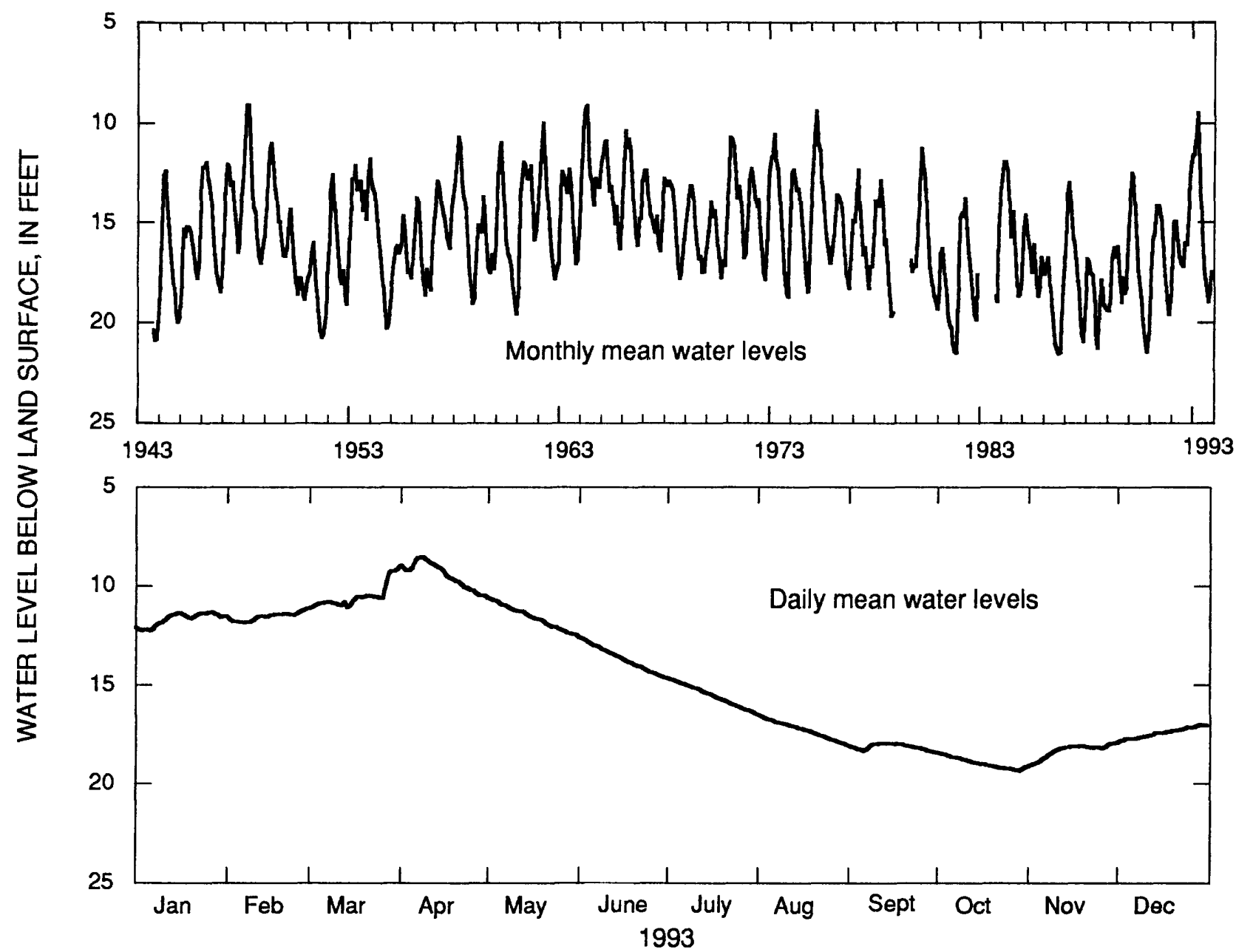

1993

JAN FEB MAR APR MAY JUNE JULY

AUG SEPT

OCT NOV DEC

MEAN

11.67

11.54

10.56

$9.49 \quad 11.57$

13.63

15.53

17.30

$\begin{array}{ll}18.17 & 18.98\end{array}$

$18.38 \quad 17.48$

LOW

12.25

$11.86 \quad 11.07$

$\begin{array}{lll}10.52 & 12.48 & 14.61\end{array}$

16.47

18.06

$18.45 \quad 19.37$

$19.10 \quad 17.89$

HIGH

11.32

11.17

9.21

8.5710 .68

$\begin{array}{ll}12.66 & 14.70\end{array}$

16.61

18.00

18.51

$17.99 \quad 17.05$

CAL YR 1993

MEAN 14.54

$\mathrm{HIGH}$

8.57

LOW $\quad 19.37$

Figure 15.--Water level in observation well 11AA01, Spalding County. 
314330084005403 Local number, $13 \mathrm{M} 007$.

LOCATION.--Lat $31^{\circ} 43^{\prime} 30^{\prime \prime}$, long 84 00'54", Hydrologic Unit 03130006.

Owner: U.S. Geological Survey, test well DP-9.

INSTRUMENTATION.--Digital recorder.

AQUIFER.--Surficial (residuum).

WELL CHARACTERISTICS.--Drilled observation well, diameter 4 in., depth $25 \mathrm{ft}$, cased to $10 \mathrm{ft}$, open hole.

DATUM.--Altitude of land-surface datum is $230 \mathrm{ft}$.

REMARKS.--None.

PERIOD OF RECORD.--April 1980 to current year.

EXTREMES FOR PERIOD OF RECORD.--Highest water level, $3.48 \mathrm{ft}$ below land-surface datum, March 7, 1984; lowest,

$13.03 \mathrm{ft}$ below land-surface datum, October 22, 1981.

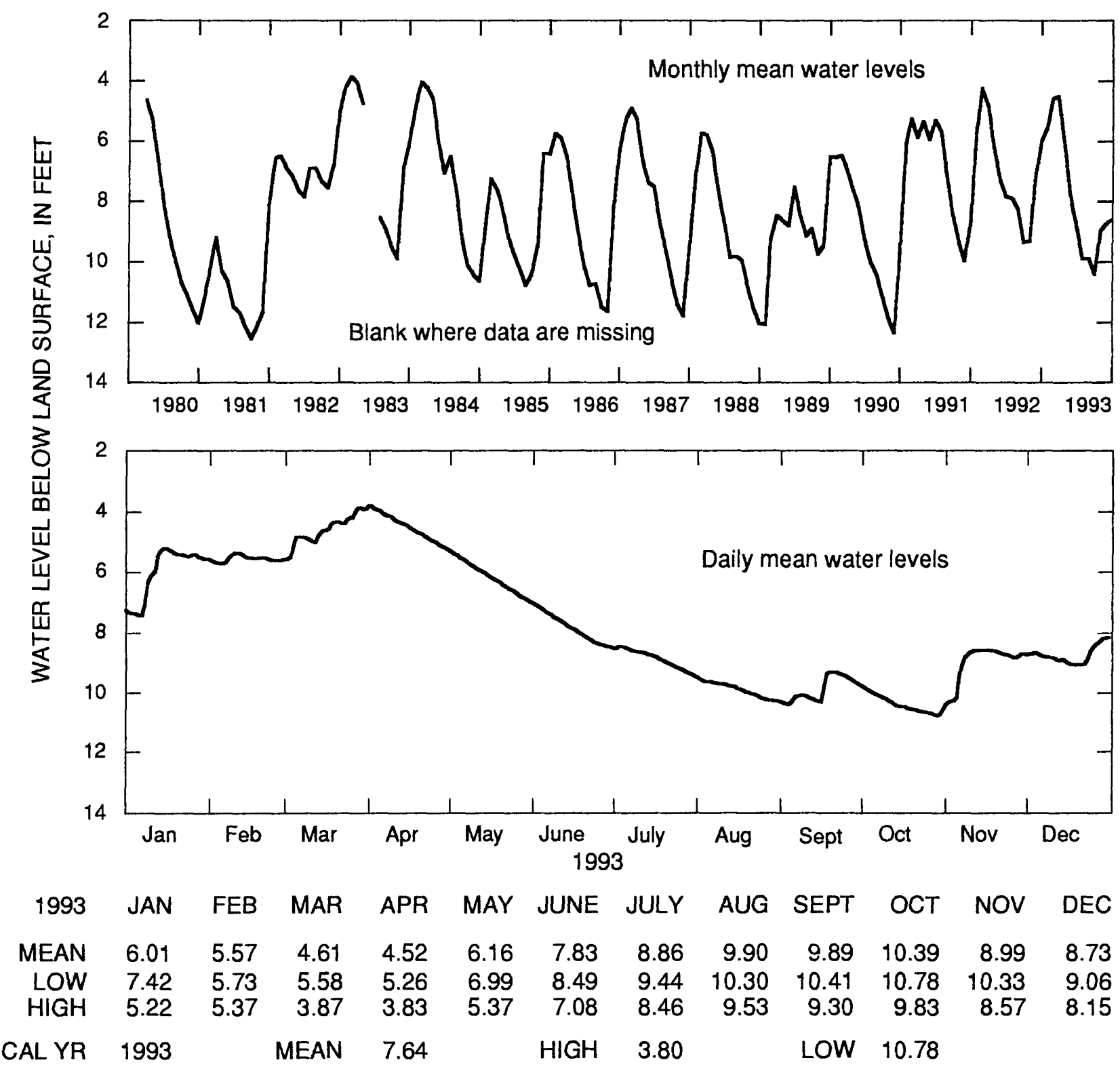

Figure 16.--Water level in observation well 13M007, Worth County. 
311009084495503 Local number, $07 \mathrm{H} 003$.

LOCATION.--Lat $31^{\circ} 10^{\prime} 08^{\prime \prime}$, long $84^{\circ} 49^{\prime} 54^{\prime \prime}$, Hydrologic Unit 03130010.

Owner: U.S. Geological Survey, test well DP-3.

INSTRUMENTATION.--Digital recorder.

AQUIFER.--Surficial (residuum).

WELL CHARACTERISTICS.--Drilled observation well, diameter 4 in., depth $40 \mathrm{ft}$, perforated casing 30 to $40 \mathrm{ft}$.

DATUM.--Altitude of land-surface datum is $180 \mathrm{ft}$.

REMARKS.--Well pumped and redeveloped August 11, 1989.

PERIOD OF RECORD.--February 1980 to current year.

EXTREMES FOR PERIOD OF RECORD.--Highest water level, $0.25 \mathrm{ft}$ below land-surface datum, January 30, 1991; lowest,

$24.19 \mathrm{ft}$ below land-surface datum, November 10, 1981.

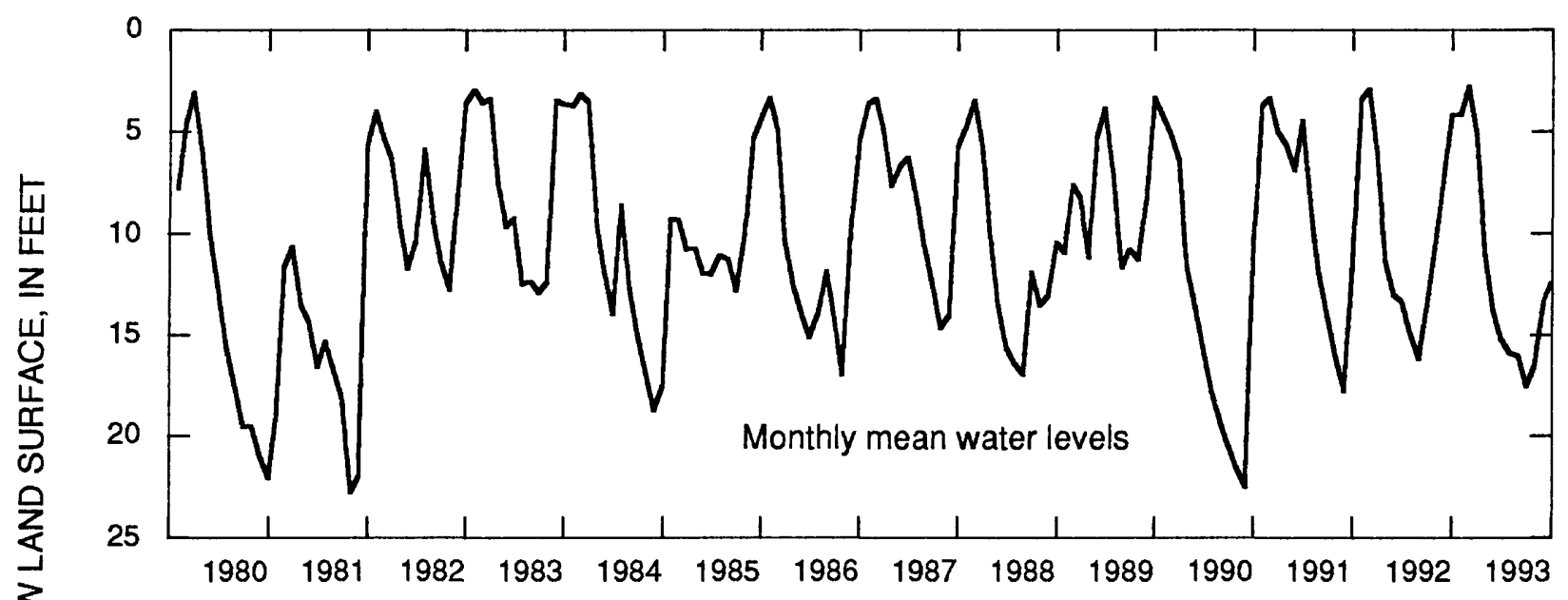

号

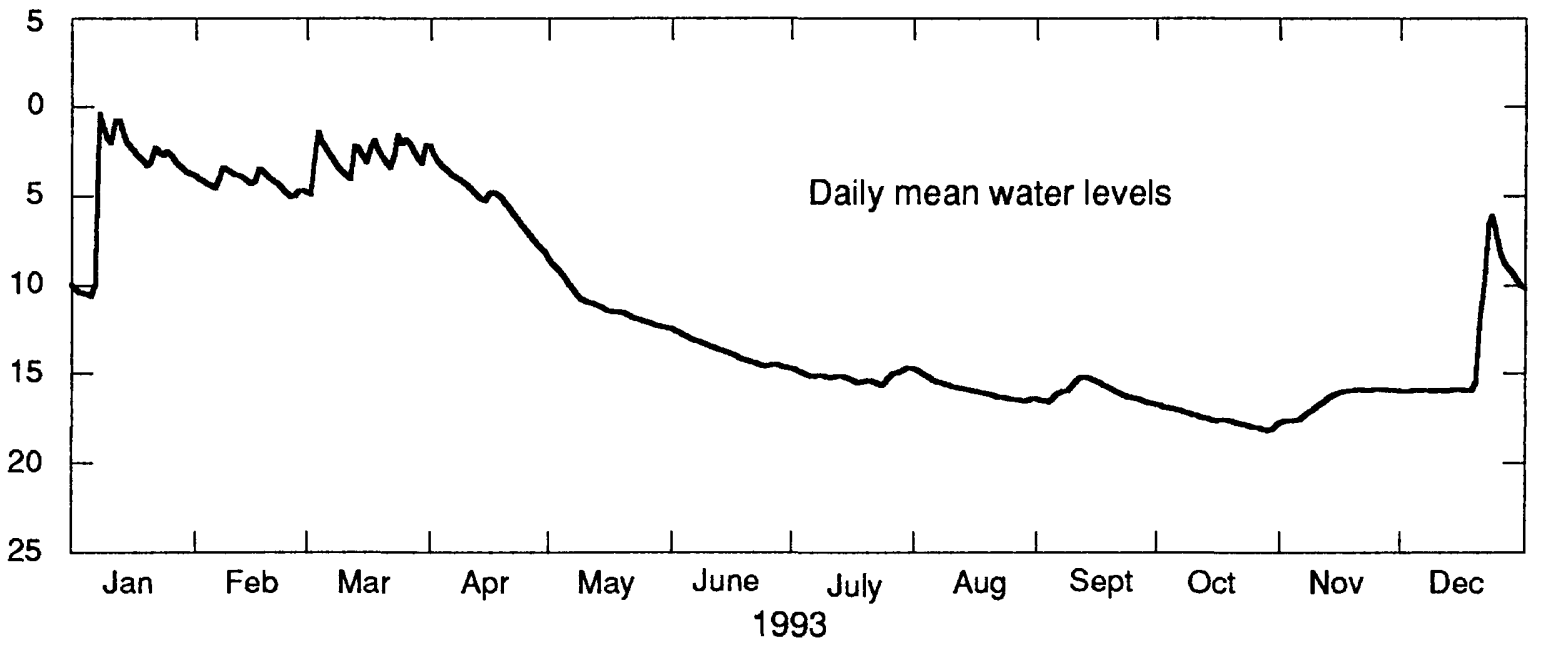

1993 JAN FEB MAR APR MAY JUNE JULY AUG SEPT OCT NOV DEC

$\begin{array}{rrrrrrrrrrrrr}\text { MEAN } & 4.22 & 4.19 & 2.83 & 5.15 & 11.09 & 13.81 & 15.19 & 15.92 & 16.06 & 17.55 & 16.56 & 13.41 \\ \text { LOW } & 10.62 & 5.04 & 4.93 & 8.15 & 12.43 & 14.71 & 15.67 & 16.58 & 16.72 & 18.19 & 17.71 & 16.02 \\ \text { HIGH } & 0.45 & 3.42 & 1.45 & 2.68 & 8.77 & 12.60 & 14.73 & 14.85 & 15.24 & 16.83 & 15.94 & 6.13 \\ \text { CAL YR } & 1993 & & \text { MEAN } & 11.37 & & \text { HIGH } & 0.45 & & \text { LOW } & 18.19 & & \end{array}$

Figure 17.--Water level in observation well 07H003, Miller County. 


\section{Coastalarea}

Water levels in surficial aquifers in the coastal area were monitored in six wells in 1993; data for five of the wells (fig. 14) are shown in figures 18-22. Water levels in surficial aquifers in the northern part of the coastal area are affected by variations in precipitation, evapotranspiration, and natural drainage (Clarke and others, 1990, p. 22). The annual mean water level in well 35 P094 was $1.9 \mathrm{ft}$ lower in 1993 than in 1992. In 1993, the annual mean water level in wells 37P116 (fig. 19) and 32R003 (fig. 20) ranged from about the same to $1.5 \mathrm{ft}$ lower than in 1992, respectively. A record-low daily mean water level was recorded in well 37P116 (fig. 19) that was about $0.1 \mathrm{ft}$ lower than the previous record low. A record-high daily mean water level was recorded in well 32R003 (fig. 20) that was about $0.1 \mathrm{ft}$ higher than the previous record high.

The water-level in the surficial aquifer in the Brunswick area is influenced by nearby pumping, precipitation, and tidal fluctuations (Clarke and others, 1990, p. 24). The annual mean water level in well 34H438 (fig. 21) in Glynn County was about $0.2 \mathrm{ft}$ lower in 1993 than in 1992. In 1993, the annual mean water level in well 32L017 (fig. 22) in the Jesup, Wayne County, area was about the same as in 1992. 
315950081161201 Local number, 35P094.

LOCATION.--Lat 31 ${ }^{\circ} 59^{\prime} 50^{\prime \prime}$, long 81'16'12", Hydrologic Unit 03060204.

Owner: University of Georgia, formerly U.S. Department of Agriculture.

INSTRUMENTATION.--Digital recorder.

AQUIFER.--Surficial (sand of Holocene and Pleistocene age).

WELL CHARACTERISTICS.--Bored observation well, diameter $30 \mathrm{in}$., depth $15 \mathrm{ft}$, cased to $15 \mathrm{ft}$, open end.

DATUM.--Altitude of land-surface datum is $18.67 \mathrm{ft}$.

REMARKS.--Responds quickly to precipitation.

PERIOD OF RECORD.--August 1942 to current year. Water levels for period, February 27 to March 23, are missing. EXTREMES FOR PERIOD OF RECORD.--Highest water level, $0.05 \mathrm{ft}$ below land-surface datum, September 26, 1953; lowest, $12.28 \mathrm{ft}$ below land-surface datum, November 30, 1972 .
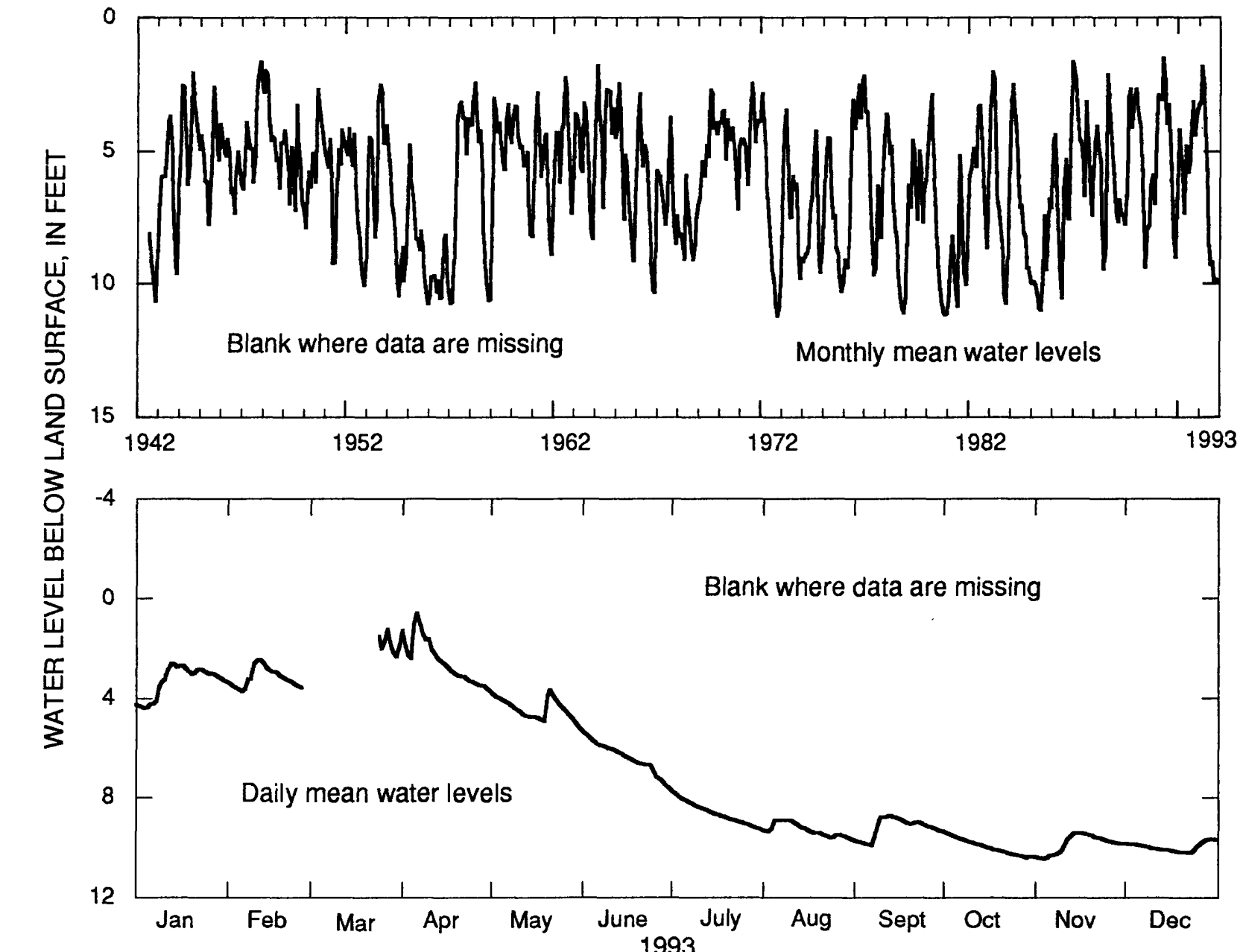

1993 JAN FEB MAR APR MAY JUNE JULY AUG SEPT OCT NOV DEC

$\begin{array}{rrrrrrrrrrrrr}\text { MEAN } & 3.32 & 3.18 & -\cdots-- & 2.51 & 4.42 & 6.38 & 8.61 & 9.29 & 9.20 & 9.95 & 9.85 & 9.97 \\ \text { LOW } & 4.40 & 3.72 & -\cdots-- & 3.65 & 5.20 & 7.60 & 9.26 & 9.65 & 9.90 & 10.39 & 10.45 & 10.20 \\ \text { HIGH } & 2.61 & 2.46 & -\cdots-- & 0.58 & 3.66 & 5.44 & 7.83 & 8.90 & 8.74 & 9.40 & 9.39 & 9.65 \\ \text { CAL YR } & 1993 & & \text { MEAN } & 6.91 & & \text { HIGH } & 0.58 & & \text { LOW } & 10.45 & & \end{array}$

Figure 18.--Water level in observation well 35P094, Chatham County. 
315906081011204 Local number, 37P116.

LOCATION.--Lat $31^{\circ} 59^{\prime} 06^{\prime \prime}$, long $81^{\circ} 01^{\prime} 12^{\prime \prime}$, Hydrologic Unit 03060204.

Owner: Georgia Geologic Survey, Skidaway Institute test well 4.

INSTRUMENTATION.--Digital recorder.

AQUIFER.--Surficial (sand of Miocene and post Miocene age).

WELL CHARACTERISTICS.--Drilled observation well, diameter 6 in., depth $85 \mathrm{ft}$, cased to $70 \mathrm{ft}$, screen to $85 \mathrm{ft}$.

DATUM.--Altitude of land-surface datum is $10 \mathrm{ft}$.

REMARKS.--Water levels for period, April 2 to June 7, are missing.

PERIOD OF RECORD.--January 1984 to current year.

EXTREMES FOR PERIOD OF RECORD.--Highest water level, $7.19 \mathrm{ft}$ below land-surface datum, October 31, 1985; lowest, $9.27 \mathrm{ft}$ below land-surface datum, March 17, 1993.
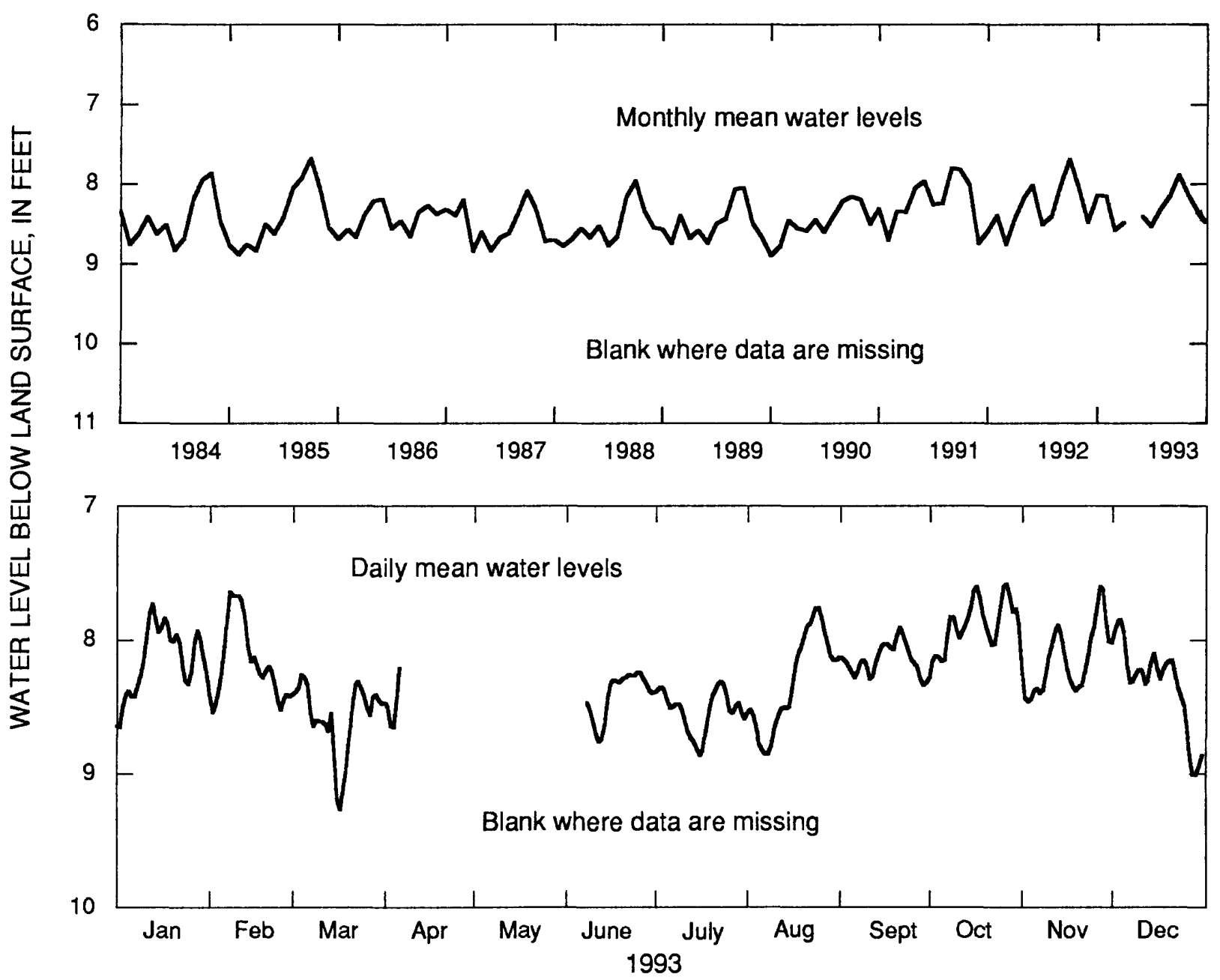

1993 JAN FEB MAR APR MAY JUNE JULY AUG SEPT OCT NOV DEC

$\begin{array}{lllllllllllll}\text { MEAN } & 8.14 & 8.16 & 8.58 & -\ldots--- & ----- & 8.41 & 8.53 & 8.31 & 8.15 & 7.89 & 8.14 & 8.33 \\ \text { LOW } & 8.65 & 8.54 & 9.27 & ---- & -\ldots-- & 8.76 & 8.86 & 8.85 & 8.34 & 8.17 & 8.46 & 9.01 \\ \text { HIGH } & 7.73 & 7.64 & 8.26 & ----- & -\ldots-- & 8.24 & 8.31 & 7.76 & 7.91 & 7.58 & 7.60 & 7.85 \\ \text { CAL YR } & 1993 & & \text { MEAN } & 8.27 & & \text { HIGH } & 7.58 & & \text { LOW } & 9.27 & & \end{array}$

Figure 19.--Water level in observation well 37P116, Chatham County. 
321240081411502 Local number, 32R003.

LOCATION.--Lat 32 ${ }^{\circ} 12^{\prime} 40^{\prime \prime}$, long 8141'15", Hydrologic Unit 03060202.

Owner: Georgia Geologic Survey, Bulloch South test well 2.

INSTRUMENTATION.--Digital recorder.

AQUIFER.--Surficial (sand of Miocene and post Miocene age).

WELL CHARACTERISTICS. --Drilled observation well, diameter 6 in., depth $155 \mathrm{ft}$, cased to $134 \mathrm{ft}$, screen to $155 \mathrm{ft}$.

DATUM.--Altitude of land-surface datum is $120 \mathrm{ft}$.

REMARKS.--Well sounded August 1982.

PERIOD OF RECORD.--February 1983 to current year.

EXTREMES FOR PERIOD OF RECORD.--Highest water level, $8.28 \mathrm{ft}$ below land-surface datum, March 6, 1993; lowest, $15.27 \mathrm{ft}$ below land-surface datum, November 14,1983 .

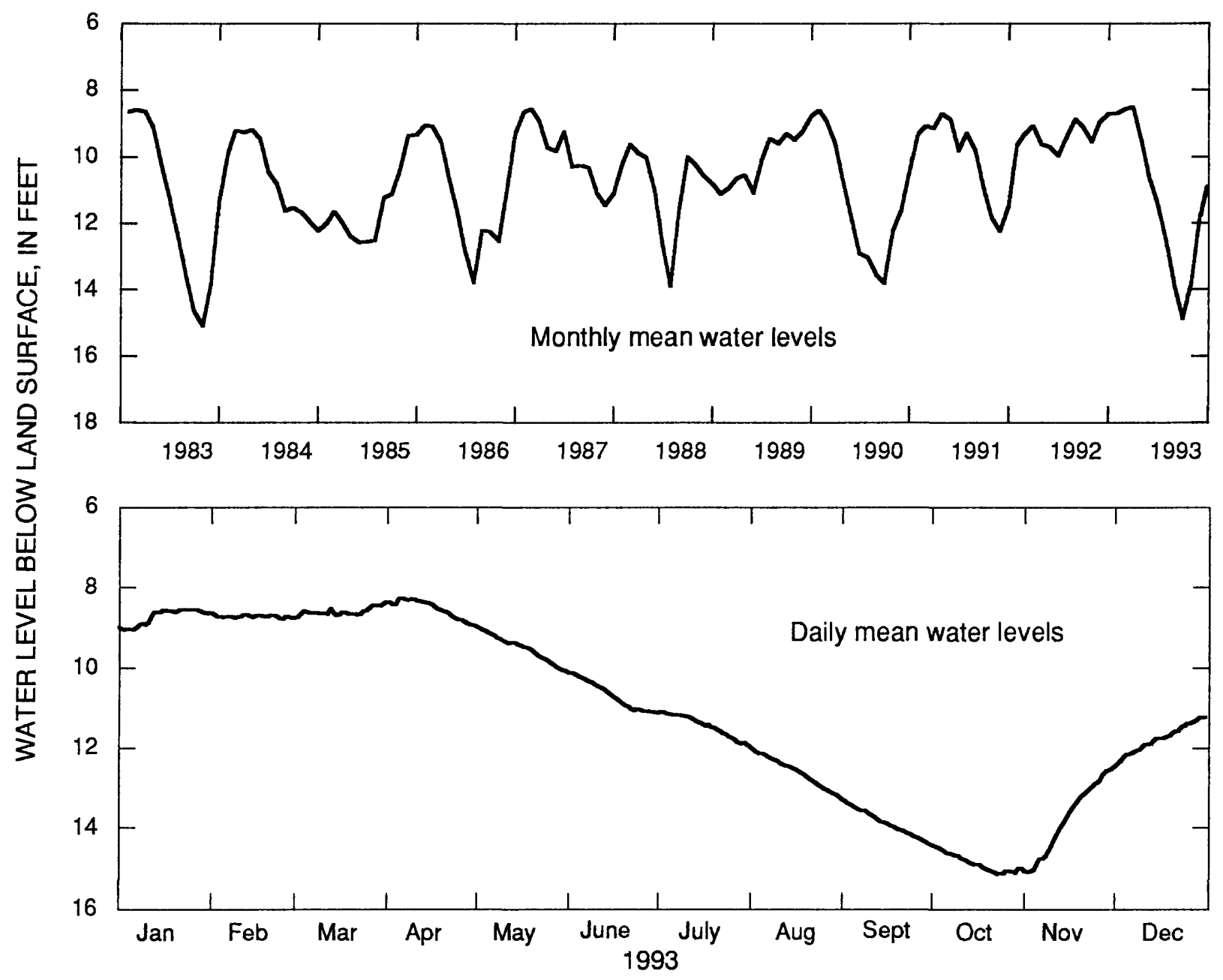

$\begin{array}{rrrrrrrrrrrrr}1993 & \text { JAN } & \text { FEB } & \text { MAR } & \text { APR } & \text { MAY } & \text { JUNE } & \text { JULY } & \text { AUG } & \text { SEPT } & \text { OCT } & \text { NOV } & \text { DEC } \\ \text { MEAN } & 8.74 & 8.72 & 8.61 & 8.53 & 9.50 & 10.67 & 11.43 & 12.59 & 13.87 & 14.87 & 13.79 & 11.78 \\ \text { LOW } & 9.05 & 8.79 & 8.74 & 8.94 & 10.08 & 11.11 & 11.93 & 13.24 & 14.40 & 15.14 & 15.10 & 12.40 \\ \text { HIGH } & 8.55 & 8.68 & 8.41 & 8.28 & 9.01 & 10.13 & 11.09 & 12.03 & 13.35 & 14.47 & 12.53 & 11.23 \\ \text { CAL YR } & 1993 & & \text { MEAN } & 11.10 & & \text { HIGH } & 8.28 & & \text { LOW } & 15.14 & & \end{array}$

Figure 20.--Water level in observation well 32R003, Bulloch County. 
310901081284403 Local number, $34 \mathrm{H} 438$.

LOCATION.--Lat 31 $09^{\prime} 01^{\prime \prime}$, long 81 $28^{\prime} 44$ ", Hydrologic Unit 03070203.

Owner: Georgia Geologic Survey, Coffin Park test well 3.

INSTRUMENTATION.--Electronic data recorder.

AQUIFER.--Surficial (sand of Miocene and post Miocene age).

WELL CHARACTERISTICS.--Drilled observation well, diameter 6 in., depth $202 \mathrm{ft}$, cased to $192 \mathrm{ft}$, screen to $202 \mathrm{ft}$.

DATUM.--Altitude of land-surface datum is $7 \mathrm{ft}$.

REMARKS.--Well pumped and sampled by Georgia Geologic Survey, January 20, 1993. Water levels for periods of missing record, January 28 to February 15, July 4-6, August 21 to September 6, and December 11-31, were estimated. PERIOD OF RECORD.--November 1983 to current year.

EXTREMES FOR PERIOD OF RECORD.--Highest water level, $2.25 \mathrm{ft}$ below land-surface datum, November 22, 1992; lowest, $8.13 \mathrm{ft}$ below land-surface datum, July 12, 1990 .

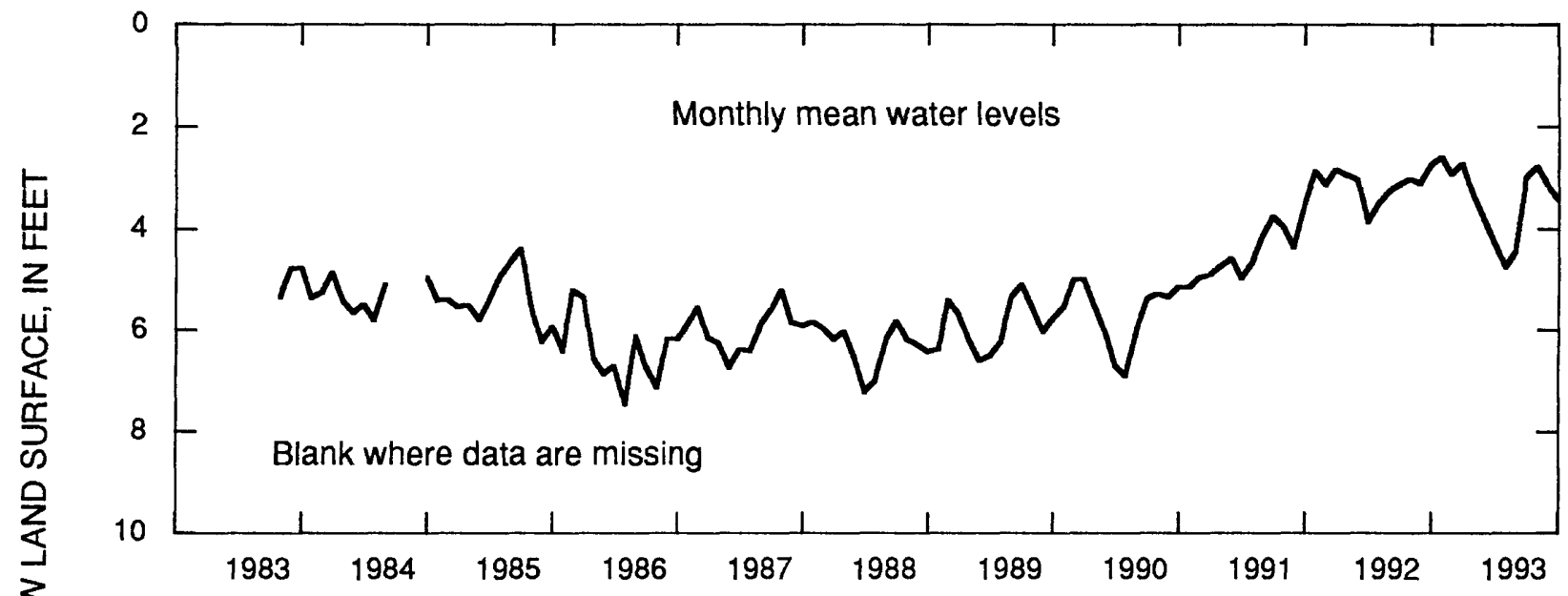

$\begin{array}{lllllllllllll}1993 & \text { JAN } & \text { FEB } & \text { MAR } & \text { APR } & \text { MAY } & \text { JUNE } & \text { JULY } & \text { AUG } & \text { SEPT } & \text { OCT } & \text { NOV } & \text { DEC } \\ \text { MEAN } & 2.74 & 2.61 & 2.93 & 2.72 & 3.33 & 3.79 & 4.24 & 4.75 & 4.46 & 3.00 & 2.78 & 3.13 \\ \text { LOW } & 3.25 & 2.87 & 3.94 & 3.13 & 3.84 & 4.11 & 4.88 & 5.13 & 4.69 & 3.93 & 3.14 & 3.70 \\ \text { HIGH } & 2.33 & 1.92 & 2.57 & 2.29 & 2.69 & 3.42 & 3.61 & 4.36 & 4.14 & 2.36 & 2.30 & 2.40 \\ \text { CAL YR } & 1993 & & \text { MEAN } & 3.38 & & \text { HIGH } & 1.92^{*} & & \text { LOW } & 5.13 & & \end{array}$

* may have been higher or lower during period of estimated record

Figure 21.--Water level in observation well 34H438, Glynn County. 
313253081433504 Local number, 32L017.

LOCATION.--Lat 31 '32'52", long 81 43'36", Hydrologic Unit 03070106.

Owner: Georgia Geologic Survey, Gardi test well 3.

INSTRUMENTATION.--Digital recorder.

AQUIFER.--Surficial (sand of Miocene and post-Miocene age).

WELL CHARACTERISTICS.--Drilled observation well, diameter 4 in., depth $215 \mathrm{ft}$, cased to $200 \mathrm{ft}$, screen to $215 \mathrm{ft}$.

DATUM.--Altitude of land-surface datum is $74 \mathrm{ft}$.

REMARKS.--None.

PERIOD OF RECORD.--June 1983 to current year.

EXTREMES FOR PERIOD OF RECORD.--Highest water level, $37.85 \mathrm{ft}$ below land-surface datum, April 16, 1984; lowest, $43.91 \mathrm{ft}$ below land-surface datum, October 8, 1990.

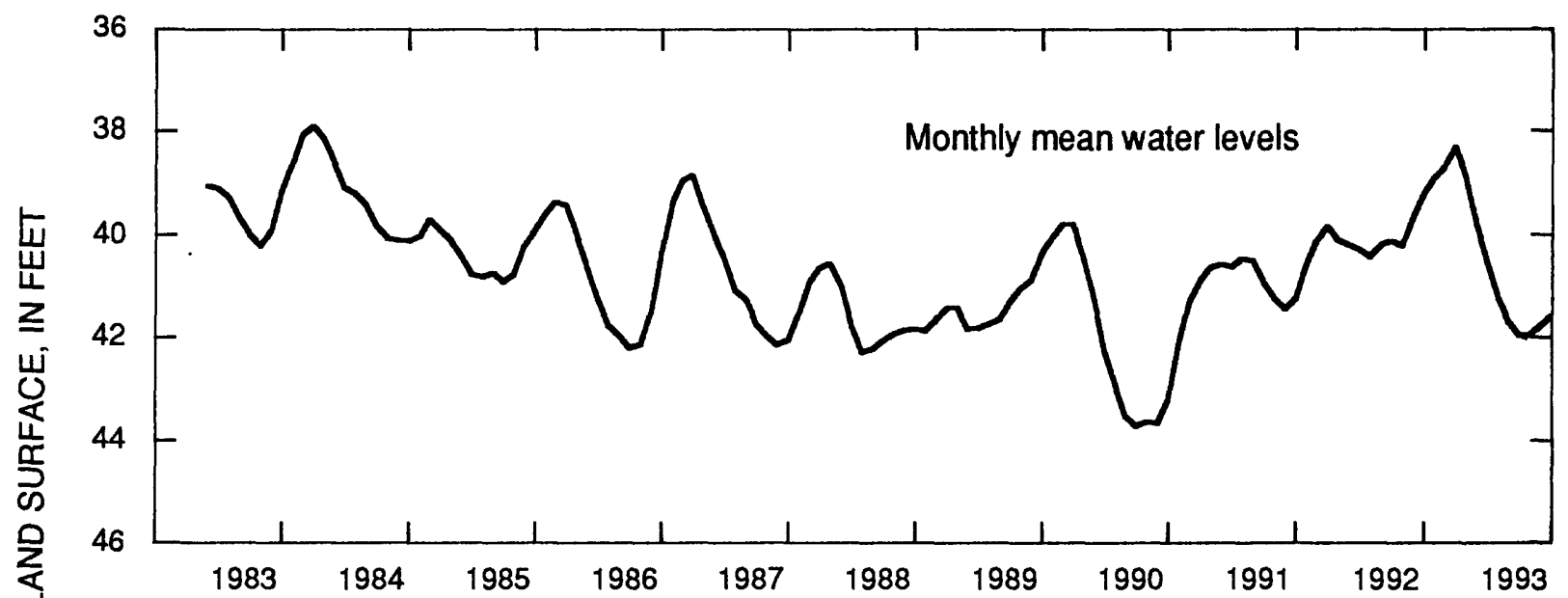

$\begin{array}{lcccccccccccc}1993 & \text { JAN } & \text { FEB } & \text { MAR } & \text { APR } & \text { MAY } & \text { JUNE } & \text { JULY } & \text { AUG } & \text { SEPT } & \text { OCT } & \text { NOV } & \text { DEC } \\ \text { MEAN } & 39.22 & 38.90 & 38.72 & 38.32 & 38.88 & 39.79 & 40.51 & 41.24 & 41.70 & 41.97 & 41.96 & 41.78 \\ \text { LOW } & 39.54 & 39.02 & 38.95 & 38.45 & 39.32 & 40.08 & 40.89 & 41.47 & 41.89 & 42.07 & 42.10 & 41.96 \\ \text { HIGH } & 38.88 & 38.78 & 38.38 & 38.23 & 38.45 & 39.38 & 40.09 & 40.96 & 41.53 & 41.87 & 41.87 & 41.58 \\ \text { CAL YR } & 1993 & & \text { MEAN } & 40.26 & & \text { HIGH } & 38.23 & & \text { LOW } & 42.10 & & \end{array}$

Figure 22.--Water level in observation well 32L017, Wayne County. 


\section{Upper Brunswick Aquifer}

The water level in the upper Brunswick aquifer was monitored in five wells in 1993; data for three of these wells (fig. 23) are summarized in this report. The upper Brunswick aquifer responds to pumping from the Upper Floridan aquifer as a result of the hydraulic connection between the aquifers (Clarke and others, 1990, p. 28). Elsewhere, the water level mainly responds to seasonal variations in recharge and discharge.

The upper Brunswick aquifer in Bulloch County is under unconfined to semiconfined conditions and is influenced by both variations in recharge from precipitation and by pumping from the Upper Floridan aquifer (Clarke and others, 1990, p. 28). The annual mean water level in well 31 U009 (fig. 24) was about $1.1 \mathrm{ft}$ lower in 1993 than in 1992.

In the Wayne and Glynn County areas, the upper Brunswick aquifer is confined and responds to nearby pumping (Clarke and others, 1990, p. 28). In 1993, the annual mean water level in well 32L016 near Jesup (fig. 25) was about $0.6 \mathrm{ft}$ higher than in 1992. The annual mean water level in well $34 \mathrm{H} 437$ near Brunswick (fig. 26) was about $0.1 \mathrm{ft}$ lower in 1993 than in 1992. 


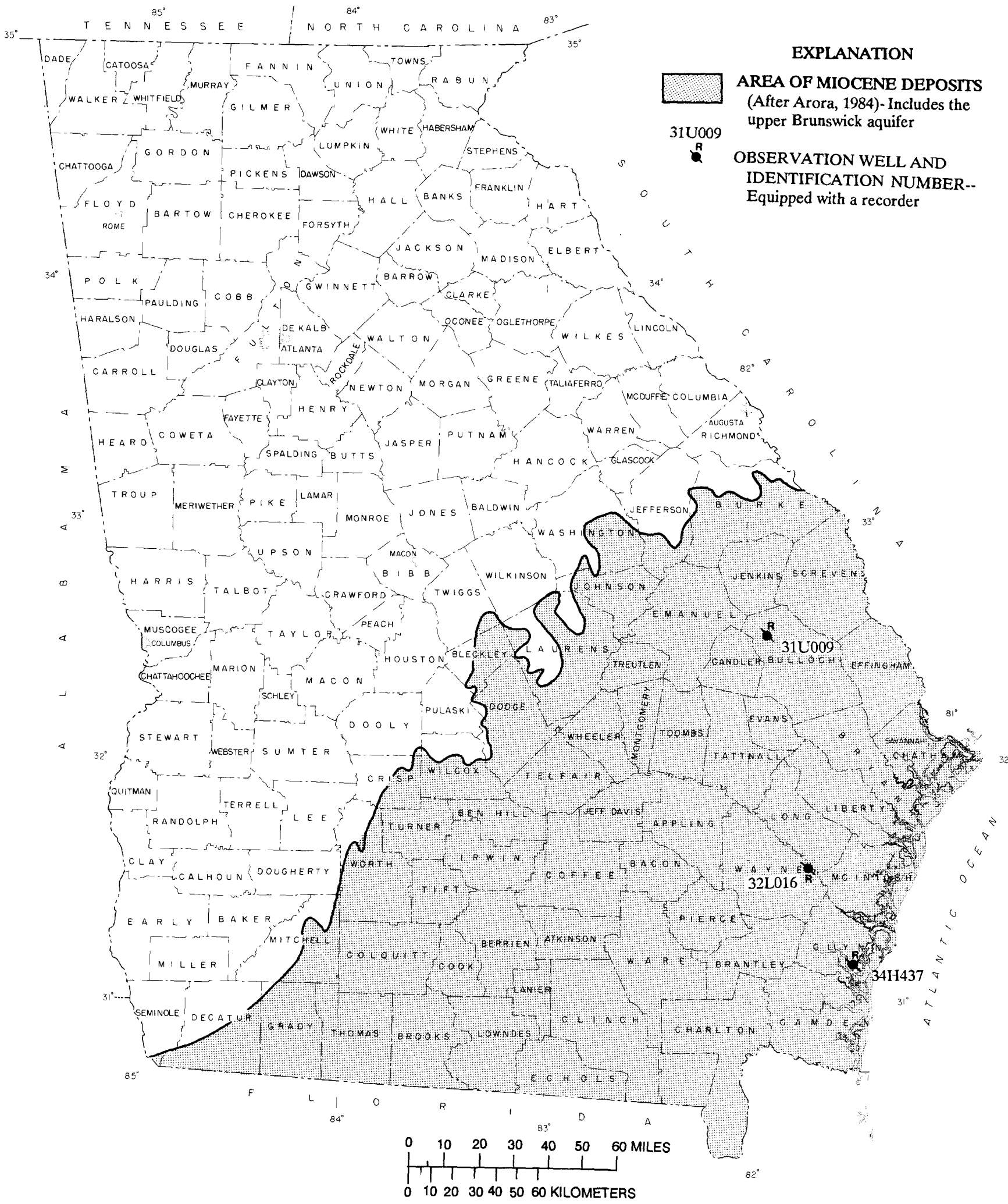

Figure 23.--Locations of observation wells completed in the upper Brunswick aquifer. [The extent of the Brunswick aquifer has not been mapped, but is within the area of Miocene deposits shown.] 
323123081511602 Local number, 31 U009.

LOCATION.--Lat 32 $31^{\prime} 23^{\prime \prime}$, long 81 $51^{\prime} 16^{\prime \prime}$, Hydrologic Unit 03060202.

Owner: Georgia Geologic Survey, Hopeulikit test well 2.

INSTRUMENTATION.--Digital recorder.

AQUIFER.--Upper Brunswick.

WELL CHARACTERISTICS.--Drilled observation well, diameter 6 in., depth $210 \mathrm{ft}$, cased to $160 \mathrm{ft}$, screen to $210 \mathrm{ft}$.

DATUM.--Altitude of land-surface datum is $205 \mathrm{ft}$.

REMARKS.--Well sounded August 1982. Well pumped and sampled by Georgia Geologic Survey, January 28 and

June 10, 1992.

PERIOD OF RECORD.--October 1982 to current year.

EXTREMES FOR PERIOD OF RECORD.--Highest water level, $70.77 \mathrm{ft}$ below land-surface datum, April 24, 1983; lowest, $78.87 \mathrm{ft}$ below land-surface datum, August 4, 1986.

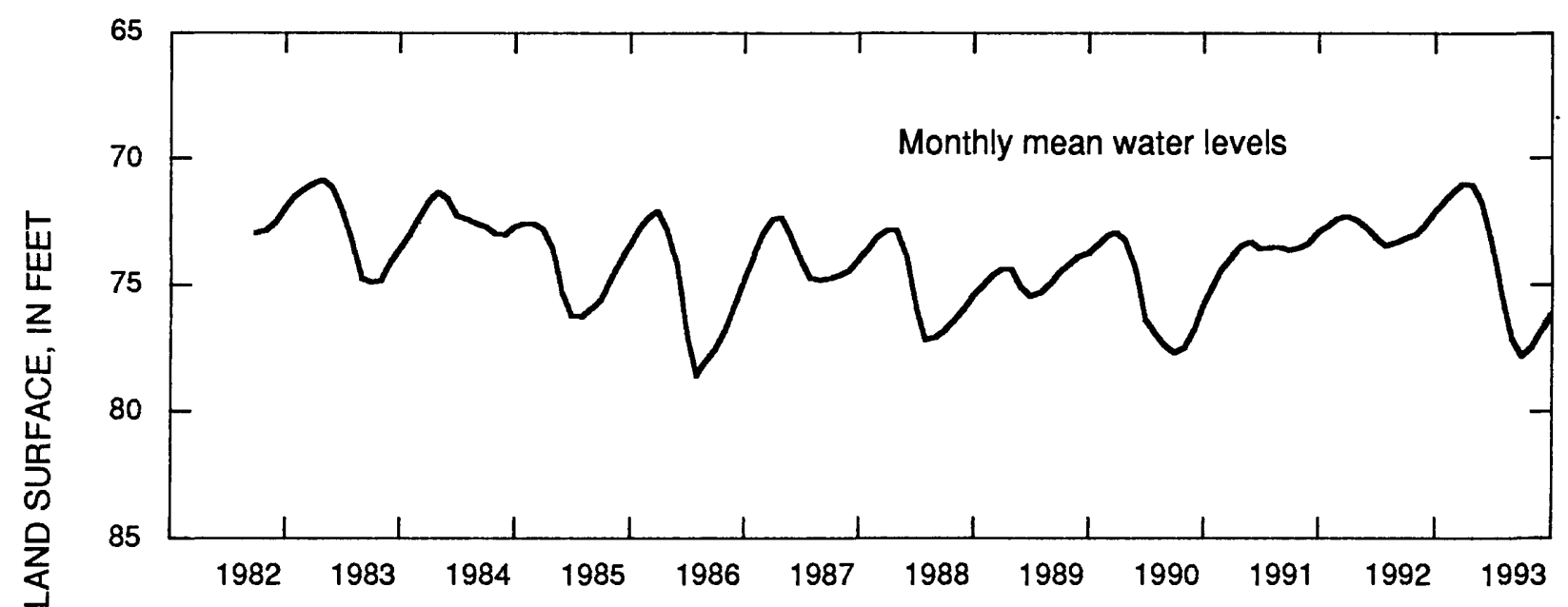

$\begin{array}{lcccccccccccc}1993 & \text { JAN } & \text { FEB } & \text { MAR } & \text { APR } & \text { MAY } & \text { JUNE } & \text { JULY } & \text { AUG } & \text { SEPT } & \text { OCT } & \text { NOV } & \text { DEC } \\ \text { MEAN } & 72.16 & 71.74 & 71.35 & 71.01 & 71.07 & 71.77 & 73.30 & 75.54 & 77.14 & 77.82 & 77.51 & 76.86 \\ \text { LOW } & 72.53 & 71.97 & 71.55 & 71.16 & 71.27 & 72.31 & 74.35 & 76.49 & 77.62 & 77.97 & 77.86 & 77.33 \\ \text { HIGH } & 71.88 & 71.56 & 71.10 & 70.95 & 70.86 & 71.28 & 72.46 & 74.53 & 76.63 & 77.67 & 77.23 & 76.51 \\ \text { CAL YR } & 1993 & & \text { MEAN } & 73.95 & & \text { HIGH } & 70.86 & & \text { LOW } & 77.97 & & \end{array}$

Figure 24.--Water level in observation well 31U009, Bulloch County. 
313253081433503, Local number, 32L016.

LOCATION.--Lat 31'32'52", long 81 '43'36", Hydrologic Unit 03070106.

Owner: Georgia Geologic Survey, Gardi test well 2.

INSTRUMENTATION.--Digital recorder.

AQUIFER.--Upper Brunswick.

WELL CHARACTERISTICS.--Drilled observation well, diameter 4 in., depth $340 \mathrm{ft}$, cased to $320 \mathrm{ft}$, screen to $340 \mathrm{ft}$.

DATUM.--Altitude of land-surface datum is $74 \mathrm{ft}$.

REMARKS.--Well sounded April 26, 1983.

PERIOD OF RECORD.--June 1983 to current year.

EXTREMES FOR PERIOD OF RECORD.--Highest water level, $49.26 \mathrm{ft}$ below land-surface datum, March 20, 1984; lowest,

$56.93 \mathrm{ft}$ below land-surface datum, January 9, 1991.
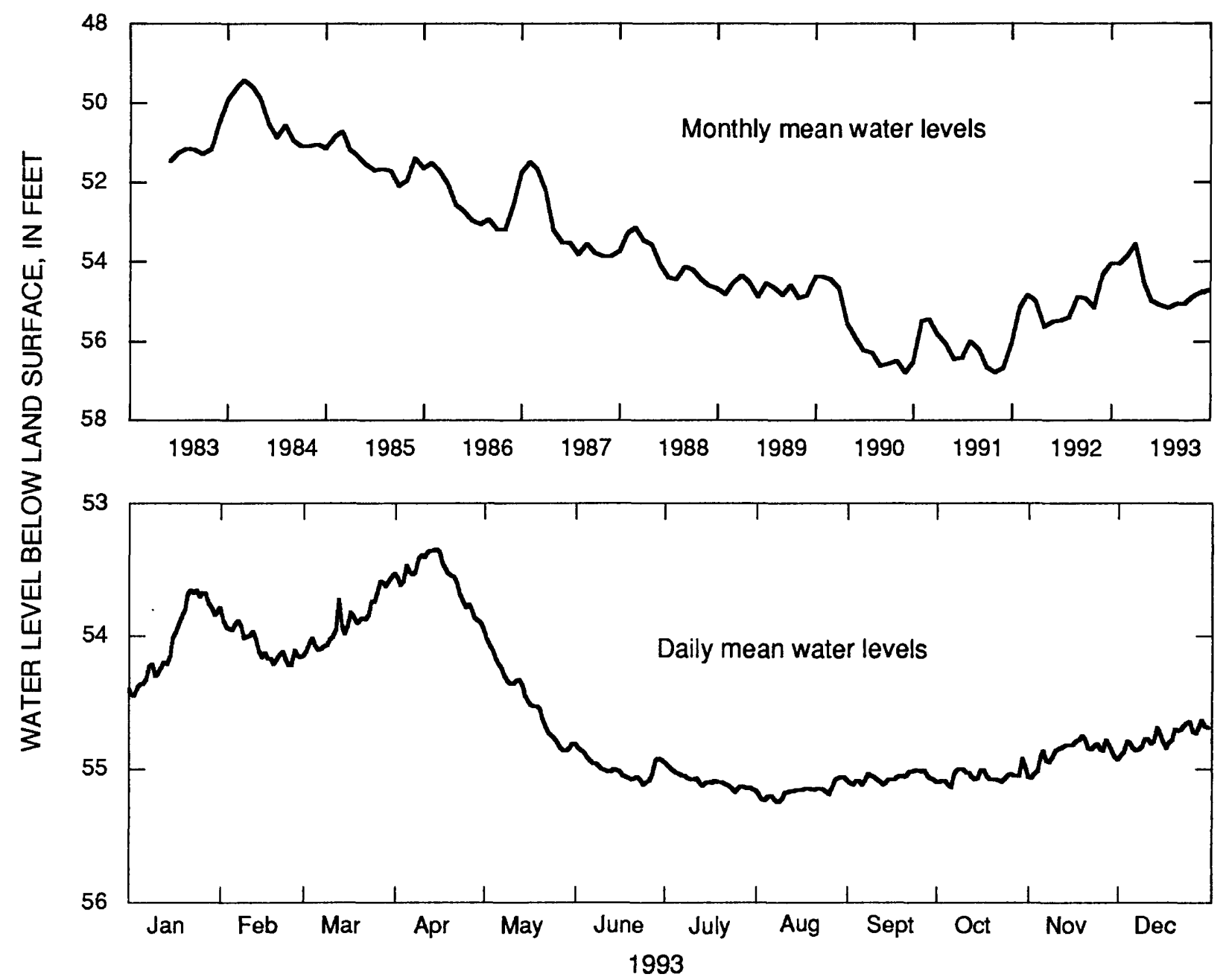

$\begin{array}{lcccccccccccc}1993 & \text { JAN } & \text { FEB } & \text { MAR } & \text { APR } & \text { MAY } & \text { JUNE } & \text { JULY } & \text { AUG } & \text { SEPT } & \text { OCT } & \text { NOV } & \text { DEC } \\ \text { MEAN } & 54.04 & 54.06 & 53.89 & 53.57 & 54.48 & 54.99 & 55.09 & 55.17 & 55.07 & 55.05 & 54.87 & 54.76 \\ \text { LOW } & 54.45 & 54.22 & 54.12 & 53.91 & 54.86 & 55.12 & 55.18 & 55.25 & 55.12 & 55.14 & 55.07 & 54.90 \\ \text { HIGH } & 53.66 & 53.89 & 53.56 & 53.35 & 54.02 & 54.84 & 54.97 & 55.06 & 55.01 & 54.92 & 54.75 & 54.63 \\ \text { CAL YR } & 1993 & & \text { MEAN } & 54.59 & & \text { HIGH } & 53.35 & & \text { LOW } & 55.25 & & \end{array}$

Figure 25.--Water level in observation well 32L016, Wayne County. 
310901081284402 Local number, $34 \mathrm{H} 437$.

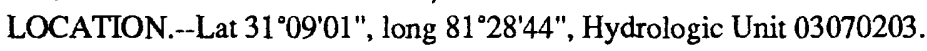

Owner: Georgia Geologic Survey, Coffin Park test well 2.

INSTRUMENTATION.--Electronic data recorder.

AQUIFER.--Upper Brunswick.

WELL CHARACTERISTICS.--Drilled observation well, diameter 4 in., depth $328 \mathrm{ft}$, cased to $315 \mathrm{ft}$, screen to $328 \mathrm{ft}$.

DATUM.--Altitude of land-surface datum is $7 \mathrm{ft}$.

REMARKS.--None.

PERIOD OF RECORD.--January 1984 to current year.

EXTREMES FOR PERIOD OF RECORD.--Highest water level, $2.26 \mathrm{ft}$ above land-surface datum, January 7, 1985; lowest,

$7.80 \mathrm{ft}$ below land-surface datum, August 30, 1987.

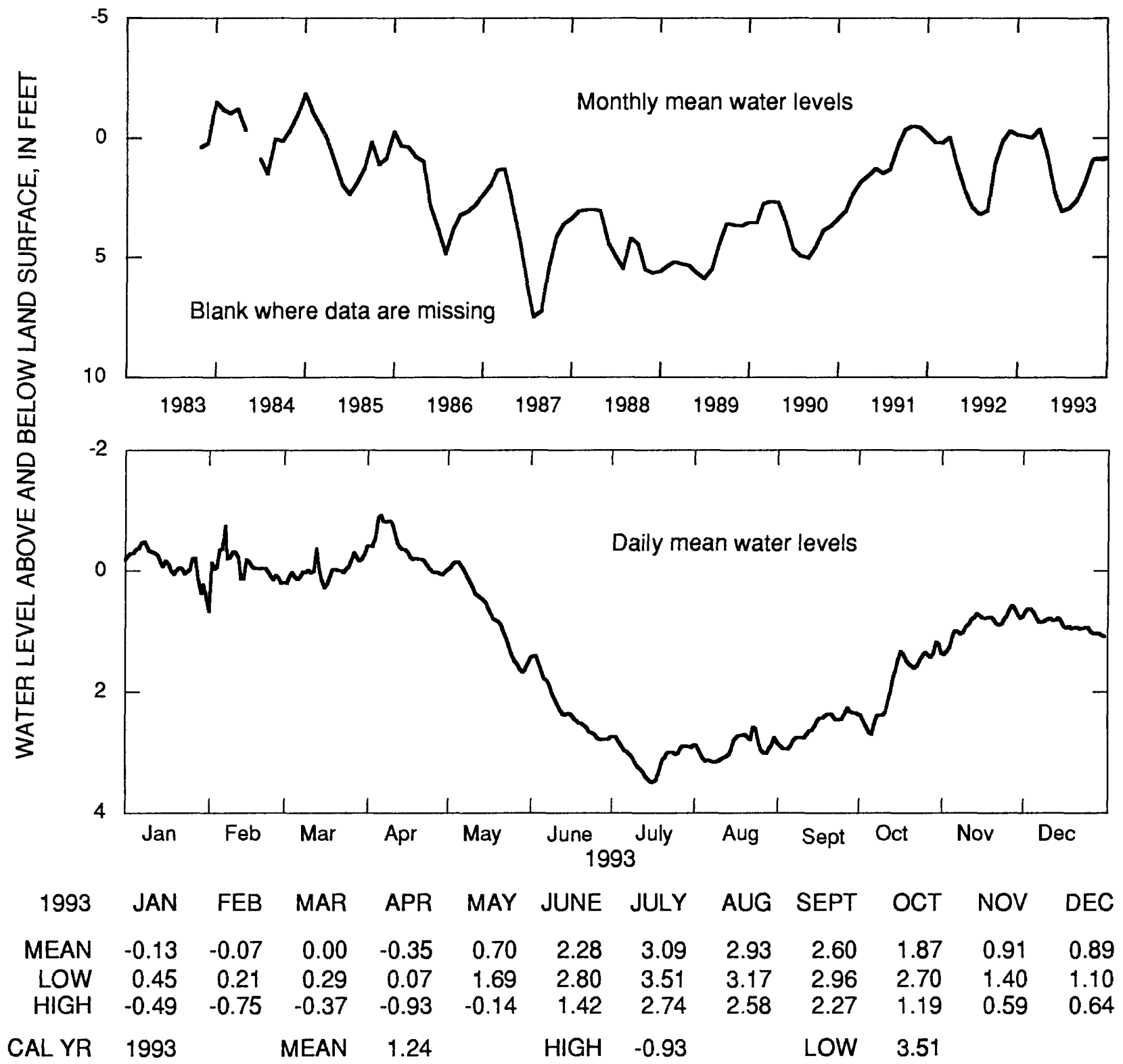

[Negative value indicates water level above land surface]

Figure 26.--Water level in observation well $34 \mathrm{H} 437$, Glynn County. 


\section{Floridan Aquifer System}

Water levels in the Floridan aquifer system are monitored in 75 wells; data for 33 of these wells are summarized in this report (figs. 27 and 60). The Floridan aquifer system includes the Upper and Lower Floridan aquifers (table 2). In and near outcrop areas, the Upper Floridan aquifer is semiconfined, and water levels in wells tapping the aquifer fluctuate seasonally in response to variations in recharge rate and pumping (Clarke and others, 1990). Near the coast, where the Upper Floridan aquifer is confined, water levels respond primarily to pumping, and fluctuations related to recharge are less pronounced (Clarke and others, 1990, p. 31). Most of the water withdrawn from the Floridan aquifer system is from the Upper Floridan aquifer; a few wells in the Savannah area withdraw water from the Lower Floridan aquifer.

\section{Upper Floridan aquifer}

The water level in the Upper Floridan aquifer is monitored in 70 wells; data for 31 of these wells are summarized in this report (fig. 27). For this report, the Upper Floridan aquifer is divided into four areas: (1) the southwestern area; (2) the south-central area; (3) the east-central area; and (4) the coastal area (fig. 27). These areas were divided on the basis of similar hydrologic settings. 


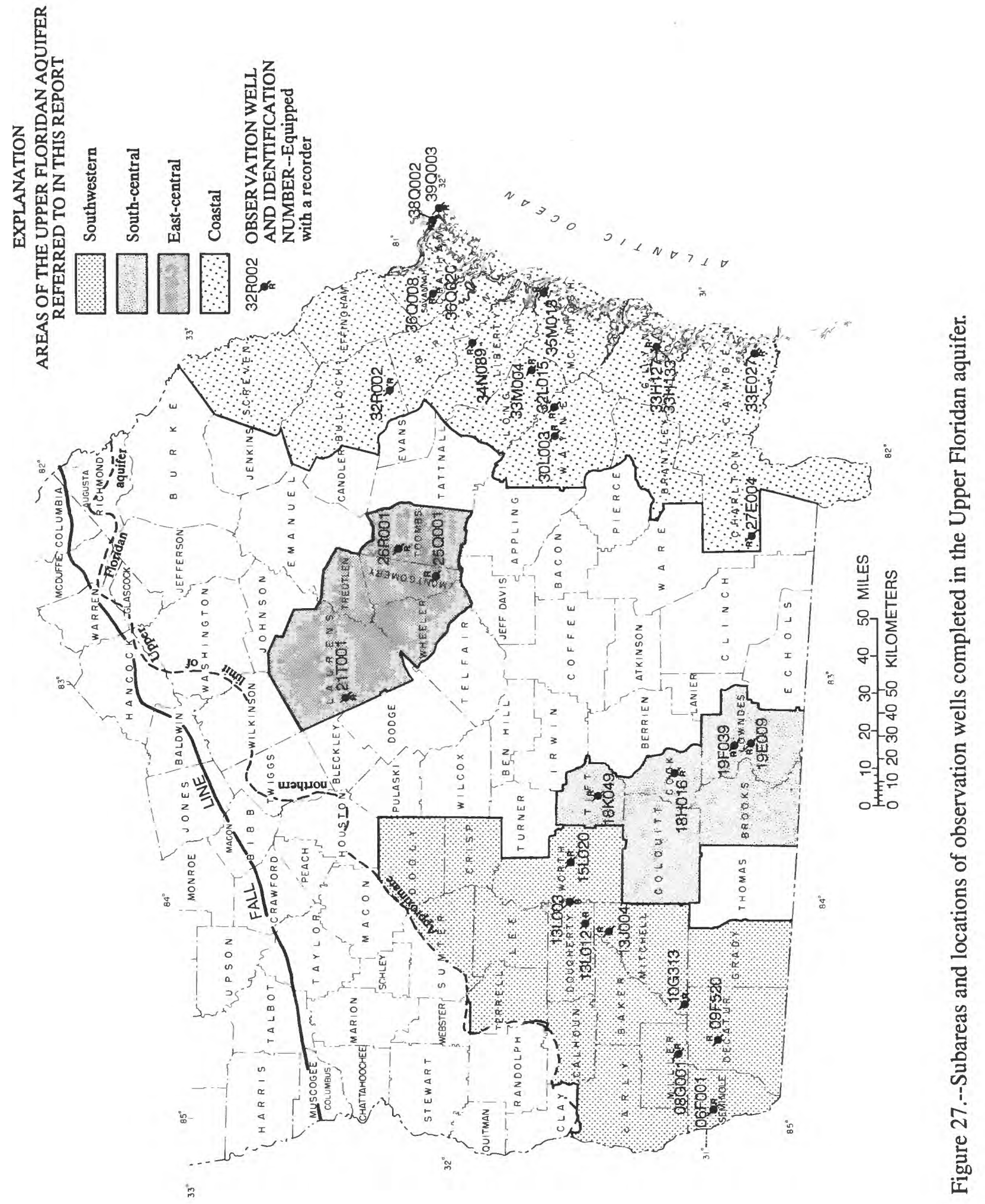




\section{Southwestern area}

The water level in the Upper Floridan aquifer in southwestern Georgia was monitored in 24 wells in 1993; data for eight of these wells (fig. 27) are summarized in figures 28-35. In the southwestern area, water levels in wells tapping the Upper Floridan aquifer respond to variations in precipitation, evapotranspiration, pumping, and streamflow (Hayes and others, 1983).

The annual mean water levels in wells 09F520 (fig. 28), 08G001 (fig. 29), 06F001 (fig. 30), and 13L012 (fig. 31) tapping the Upper Floridan aquifer ranged from about the same to $2.7 \mathrm{ft}$ lower in 1993 than in 1992. These four wells are near the Flint River or its tributaries where the aquifer is hydraulically connected to the streams.

In areas away from the Flint River and its tributaries, the Upper Floridan aquifer is confined by thicker overburden, is not well connected to streams, and the water level is not rapidly influenced by precipitation (Torak and others, 1991). Water-level fluctuations and trends in these areas are indicated by the hydrographs for wells 10G313 (fig. 32), 13L003 (fig. 33), 13J004 (fig. 34), and 15L020 (fig. 35). The annual mean water levels in these wells ranged from about $0.6 \mathrm{ft}$ lower to about $1.6 \mathrm{ft}$ higher in 1993 than in 1992. A record-high daily mean water level was recorded in well $13 \mathrm{~J} 004$ (fig. 34) that was $0.2 \mathrm{ft}$ higher than the previous record high. A record-low daily mean water level was recorded in well $15 \mathrm{~L} 020$ (fig. 35) that was $1.2 \mathrm{ft}$ lower than the previous record low. 
305736084355801 Local number, 09F520.

LOCATION.--Lat 3057'42", long 84'35'46", Hydrologic Unit 03130008.

Owner: Graham Bolton.

INSTRUMENTATION.--Digital recorder.

AQUIFER.--Upper Floridan aquifer.

WELL CHARACTERISTICS.--Unused irrigation well, diameter 12 in., depth $251 \mathrm{ft}$, cased to $130 \mathrm{ft}$, open hole.

DATUM.--Altitude of land-surface datum is $128 \mathrm{ft}$.

REMARKS.--This well is about $15 \mathrm{ft}$ from an irrigation well.

PERIOD OF RECORD.--June 1969 to current year.

EXTREMES FOR PERIOD OF RECORD.--Highest water level, $34.86 \mathrm{ft}$ below land-surface datum, April 15, 1984; lowest,

$54.89 \mathrm{ft}$ below land-surface datum, September 22, 1990.

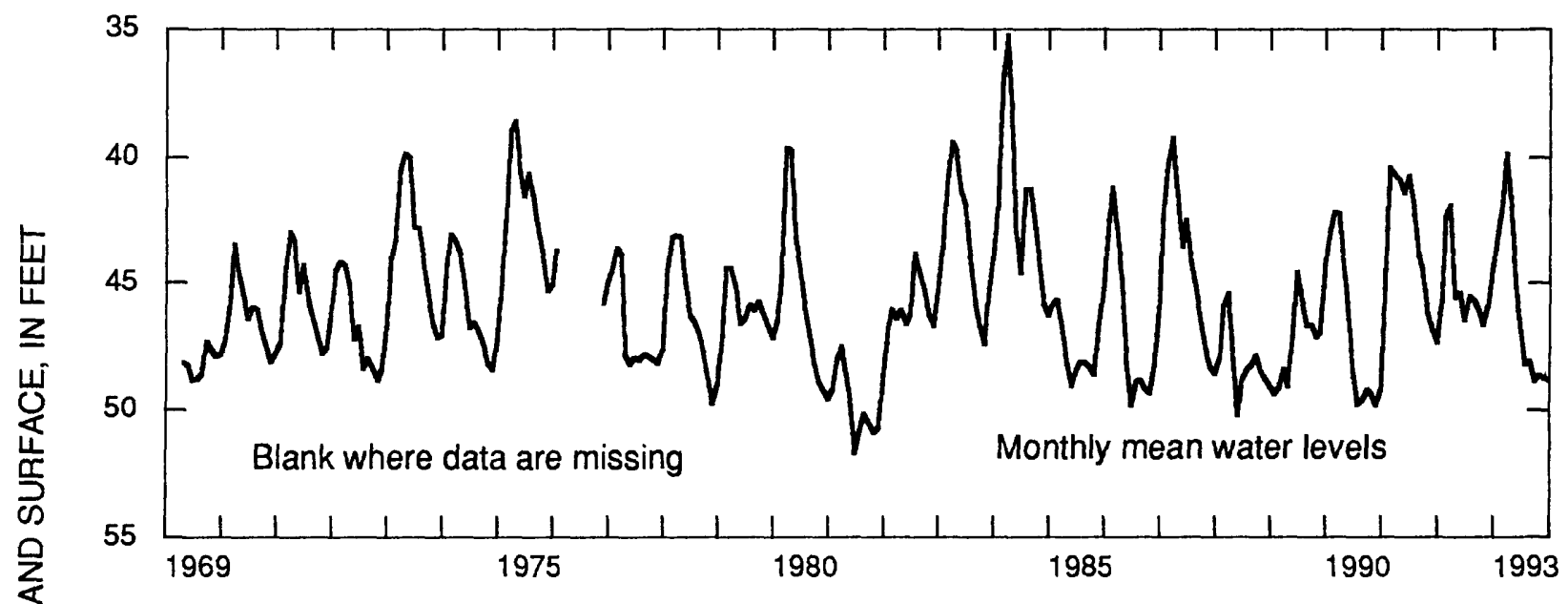

1993 JAN FEB MAR APR MAY JUNE JULY AUG SEPT OCT NOV DEC

$\begin{array}{lllllllllllll}\text { MEAN } & 44.50 & 43.18 & 42.14 & 39.86 & 41.95 & 45.24 & 46.72 & 48.21 & 48.07 & 48.84 & 48.65 & 48.78 \\ \text { LOW } & 45.91 & 43.28 & 43.22 & 42.65 & 46.66 & 50.68 & 52.41 & 52.85 & 51.05 & 51.67 & 49.04 & 48.85 \\ \text { HIGH } & 43.17 & 43.11 & 40.55 & 39.30 & 40.18 & 42.85 & 45.21 & 46.62 & 47.63 & 48.11 & 48.50 & 48.71 \\ \text { CAL YR } & 1993 & & \text { MEAN } & 45.53 & & \text { HIGH } & 39.30 & & \text { LOW } & 53.12 & & \end{array}$

Figure 28.--Water level in observation well 09F520, Decatur County. 
310651084404501 Local number, $08 \mathrm{G} 001$.

LOCATTON.--Lat $31^{\circ} 06^{\prime} 51^{\prime \prime}$, long 8440'45", Hydrologic Unit 03130010.

Owner: Viercocken.

INSTRUMENTATION.--Digital recorder.

AQUIFER.--Upper Floridan aquifer.

WELL CHARACTERISTICS.--Drilled unused irrigation well, diameter 12 in., depth $255 \mathrm{ft}$, cased to $130 \mathrm{ft}$, open hole.

DATUM.--Altitude of land-surface datum is $150 \mathrm{ft}$.

REMARKS.--None.

PERIOD OF RECORD.--February 1977 to current year.

EXTREMES FOR PERIOD OF RECORD.--Highest water level, $11.18 \mathrm{ft}$ below land-surface datum, April 11, 1984; lowest, $43.88 \mathrm{ft}$ below land-surface datum, July $17,1981$.

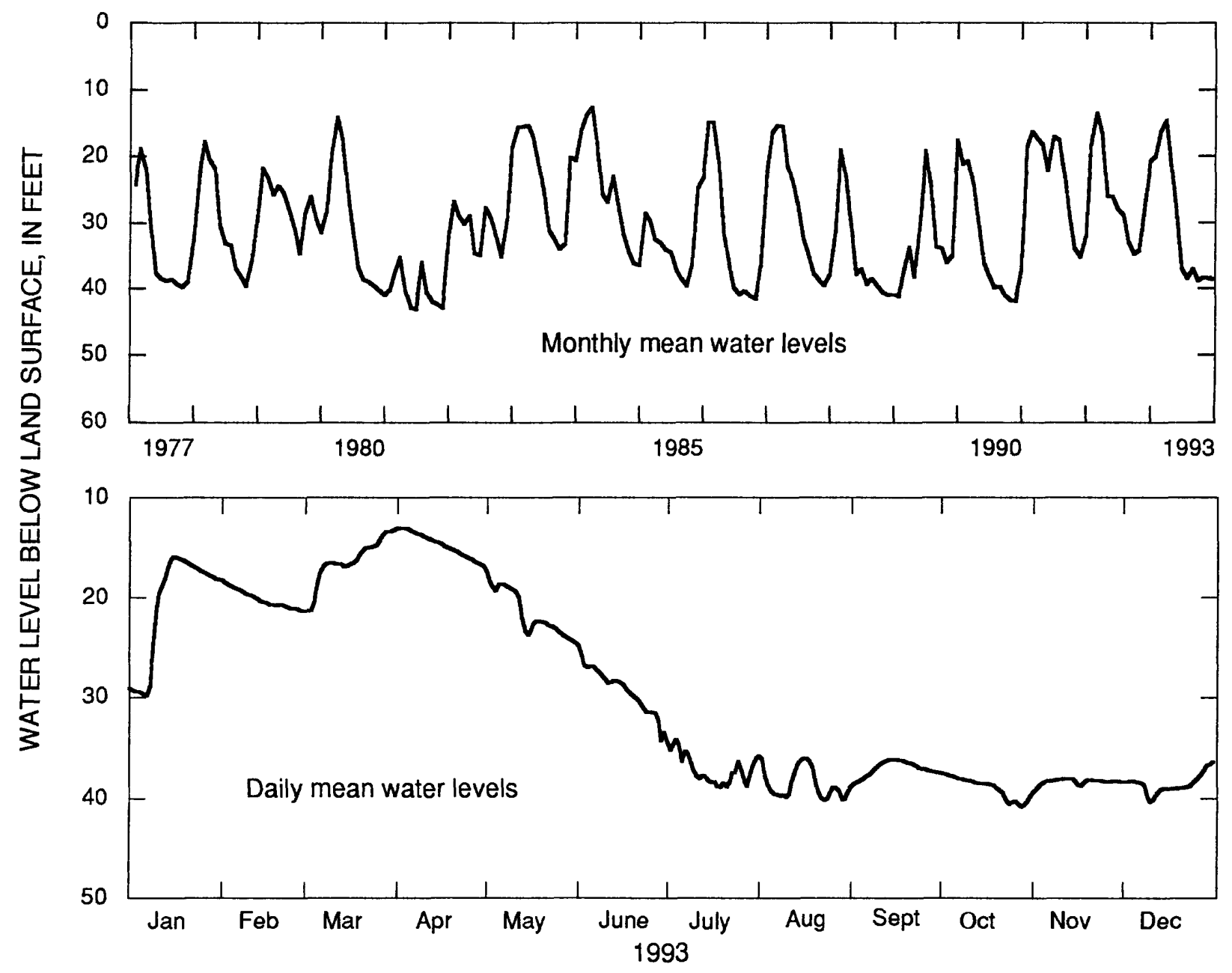

1993 JAN FEB MAR APR MAY JUNE JULY AUG SEPT OCT NOV DEC

$\begin{array}{lllllllllllll}\text { MEAN } & 20.75 & 20.12 & 16.34 & 14.66 & 21.55 & 29.25 & 37.06 & 38.51 & 37.05 & 38.92 & 38.35 & 38.58\end{array}$

$\begin{array}{llllllllllllll}\text { LOW } & 29.81 & 21.35 & 21.37 & 16.81 & 24.57 & 34.23 & 38.92 & 40.24 & 38.58 & 40.85 & 39.07 & 40.39\end{array}$

$\begin{array}{lllllllllllll}\text { HIGH } & 15.85 & 18.51 & 13.19 & 13.01 & 18.23 & 25.73 & 34.09 & 35.99 & 36.08 & 37.54 & 38.02 & 36.37\end{array}$

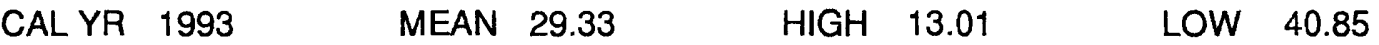

Figure 29.--Water level in observation well 08G001, Miller County. 
305356084534601 Local number, 06F001.

LOCATION.--Lat 30 $54^{\prime} 01^{\prime \prime}$, long 84'53'40", Hydrologic Unit 03130004.

Owner: Roddenbery Company Farms, test well 1.

INSTRUMENTATION.--Digital recorder.

AQUIFER.--Upper Floridan aquifer.

WELL CHARACTERISTICS.--Drilled observation well, diameter 4 in., depth $150 \mathrm{ft}$, cased to $98.5 \mathrm{ft}$, open hole.

DATUM.-Altitude of land-surface datum is $110 \mathrm{ft}$.

REMARKS.--Borehole geophysical survey conducted August 10, 1983. Well pumped and redeveloped August 10, 1989.

PERIOD OF RECORD.--March 1979 to July 1982, August 1983 to current year.

EXTREMES FOR PERIOD OF RECORD.--Highest water level, $4.13 \mathrm{ft}$ below land-surface datum, March 8, 1984; lowest,

$35.65 \mathrm{ft}$ below land-surface datum, October 5, 1986.
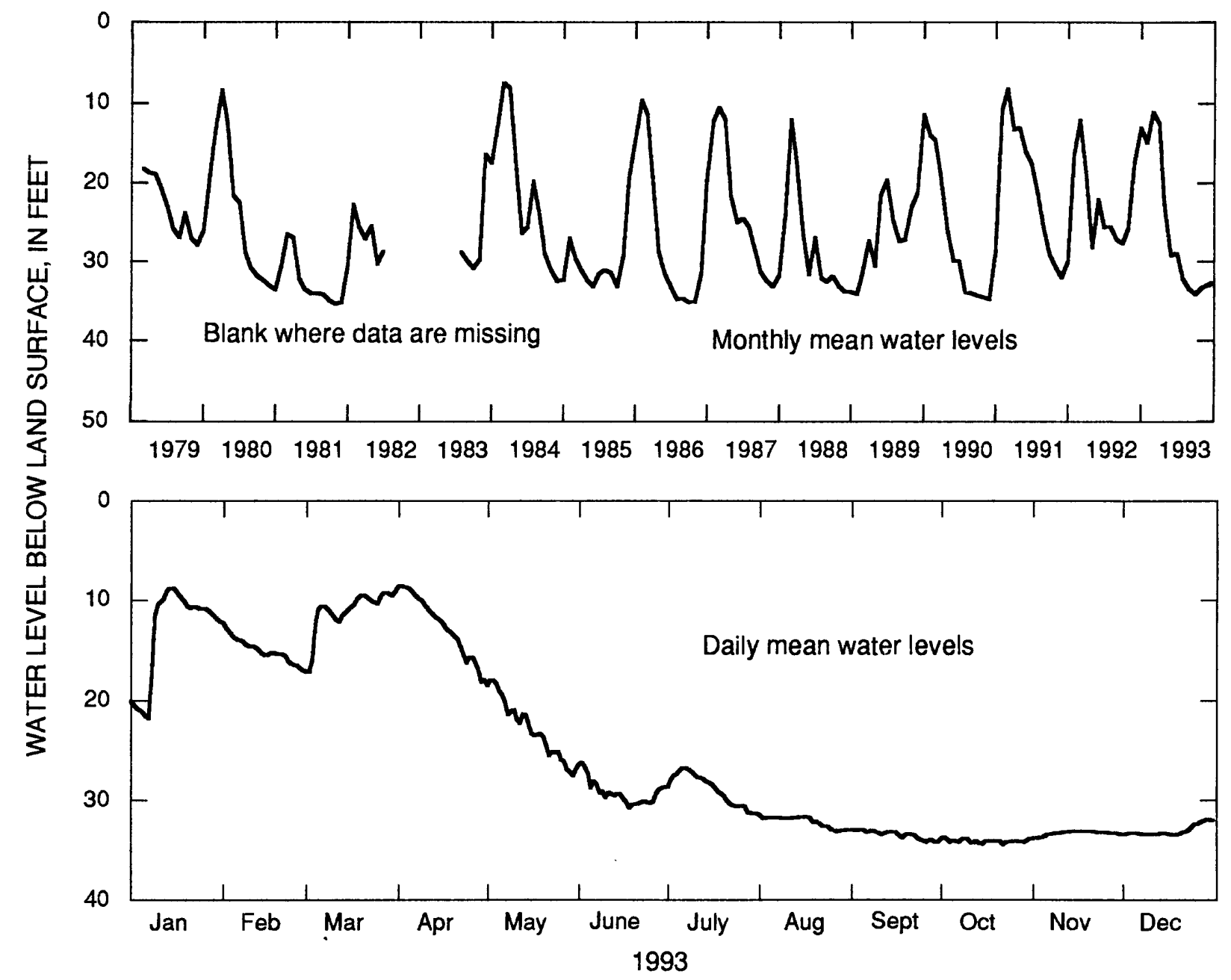

\begin{tabular}{|c|c|c|c|c|c|c|c|c|c|c|c|c|}
\hline 1993 & JAN & FEB & MAR & APR & MAY & JUNE & JULY & AUG & SEP ${ }^{\circ}$ & OCT & NOV & DEC \\
\hline MEAN & 13.09 & & & 12 & 22.87 & & & & & & & \\
\hline $\begin{array}{l}\text { LOW } \\
\text { HIGH }\end{array}$ & $\begin{array}{r}21.85 \\
8.81\end{array}$ & & $\begin{array}{r}17.19 \\
9.13\end{array}$ & $\begin{array}{r}18 . \\
8 .\end{array}$ & & & & & & & & \\
\hline AL YR & 1993 & & MEAN & 24.95 & & $\mathrm{HIGH}$ & 8.59 & & LOW & 34.47 & & \\
\hline
\end{tabular}

Figure 30.--Water level in observation well 06F001, Seminole County. 
313105084064302 Local number, 13 L012.

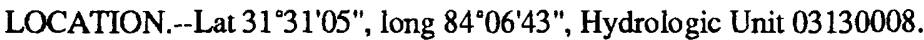

Owner: U.S. Geological Survey, test well 3.

INSTRUMENTATION.--Digital recorder.

AQUIFER.--Upper Floridan aquifer.

WELL CHARACTERISTICS.--Drilled observation well, diameter 4 in., depth $218 \mathrm{ft}$, cased to $54 \mathrm{ft}$, open hole.

DATUM.-Altitude of land-surface datum is $195 \mathrm{ft}$.

REMARKS.--Well pumped and redeveloped August 17, 1988. Water levels for periods of missing record, August 4-11 and September 11-28, were estimated.

PERIOD OF RECORD.--June 1977 to current year.

EXTREMES FOR PERIOD OF RECORD.--Highest water level, $21.92 \mathrm{ft}$ below land-surface datum, March 2, 1979; lowest, $48.18 \mathrm{ft}$ below land-surface datum, July 1,1981 .

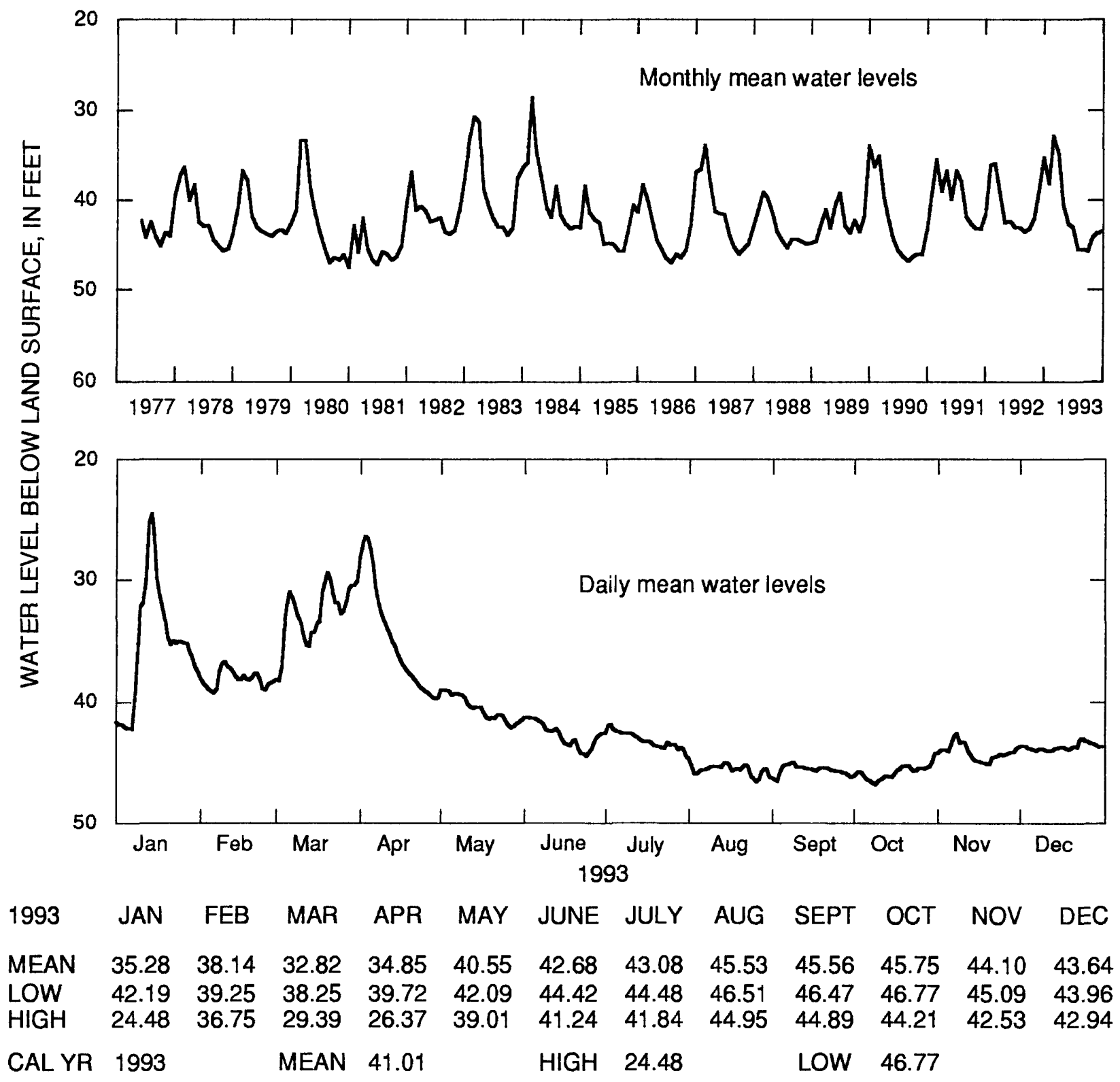

Figure 31.--Water level in observation well 13L012, Dougherty County. 
310507084262201 Local number, 10G313.

LOCATION.--Lat $31^{\circ} 05^{\prime} 07^{\prime \prime}$, long $84^{\circ} 26^{\prime} 22^{\prime \prime}$, Hydrologic Unit 03130008.

Owner: Harvey Meinders.

INSTRUMENTATION.--Digital recorder.

AQUIFER.--Upper Floridan aquifer.

WELL CHARACTERISTICS.--Cable-tool, observation well, diameter $12 \mathrm{in}$., depth $250 \mathrm{ft}$, cased to $87 \mathrm{ft}$, open hole.

DATUM.--Altitude of land-surface datum is $145 \mathrm{ft}$.

REMARKS.--None.

PERIOD OF RECORD.--November 1961 to September 1968, April 1976 to current year.

EXTREMES FOR PERIOD OF RECORD.--Highest water level, $32.98 \mathrm{ft}$ below land-surface datum, April 9, 1984; lowest, $60.26 \mathrm{ft}$ below land-surface datum, January 1, 1982.

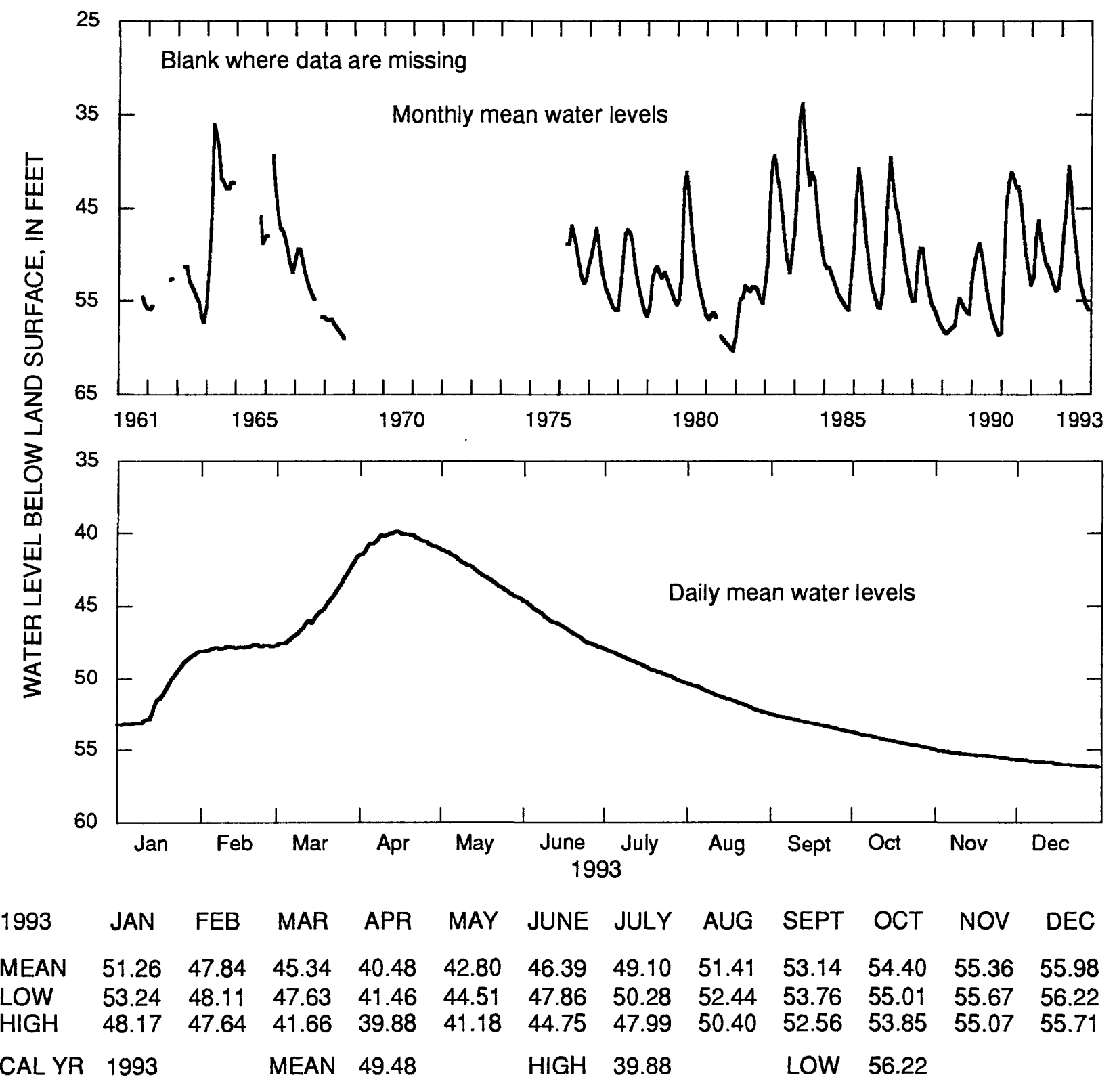

Figure 32.--Water level in observation well 10G313, Mitchell County. 
313748084002901 Local number, 13 L003.

LOCATION.--Lat $31^{\circ} 33^{\prime} 13^{\prime \prime}$, long $84^{\circ} 00^{\prime 2} 21^{\prime \prime}$, Hydrologic Unit 03130008.

Owner: City of Albany and Dougherty County.

INSTRUMENTATION.--Digital recorder.

AQUIFER.--Upper Floridan aquifer.

WELL CHARACTERISTICS.--Drilled unused supply well, diameter 6 in., depth $259 \mathrm{ft}$, cased to $206 \mathrm{ft}$, open hole.

DATUM.--Altitude of land-surface datum is $225 \mathrm{ft}$.

REMARKS.--Well pumped and sounded June 21, 1978; water-quality sample collected at conclusion of pumping.

Borehole geophysical survey conducted March 17, 1977.

PERIOD OF RECORD.--January 1963 to current year.

EXTREMES FOR PERIOD OF RECORD.--Highest water level, $17.41 \mathrm{ft}$ below land-surface datum, April 2, 1965; lowest,

$44.89 \mathrm{ft}$ below land-surface datum, December 13, 1981.

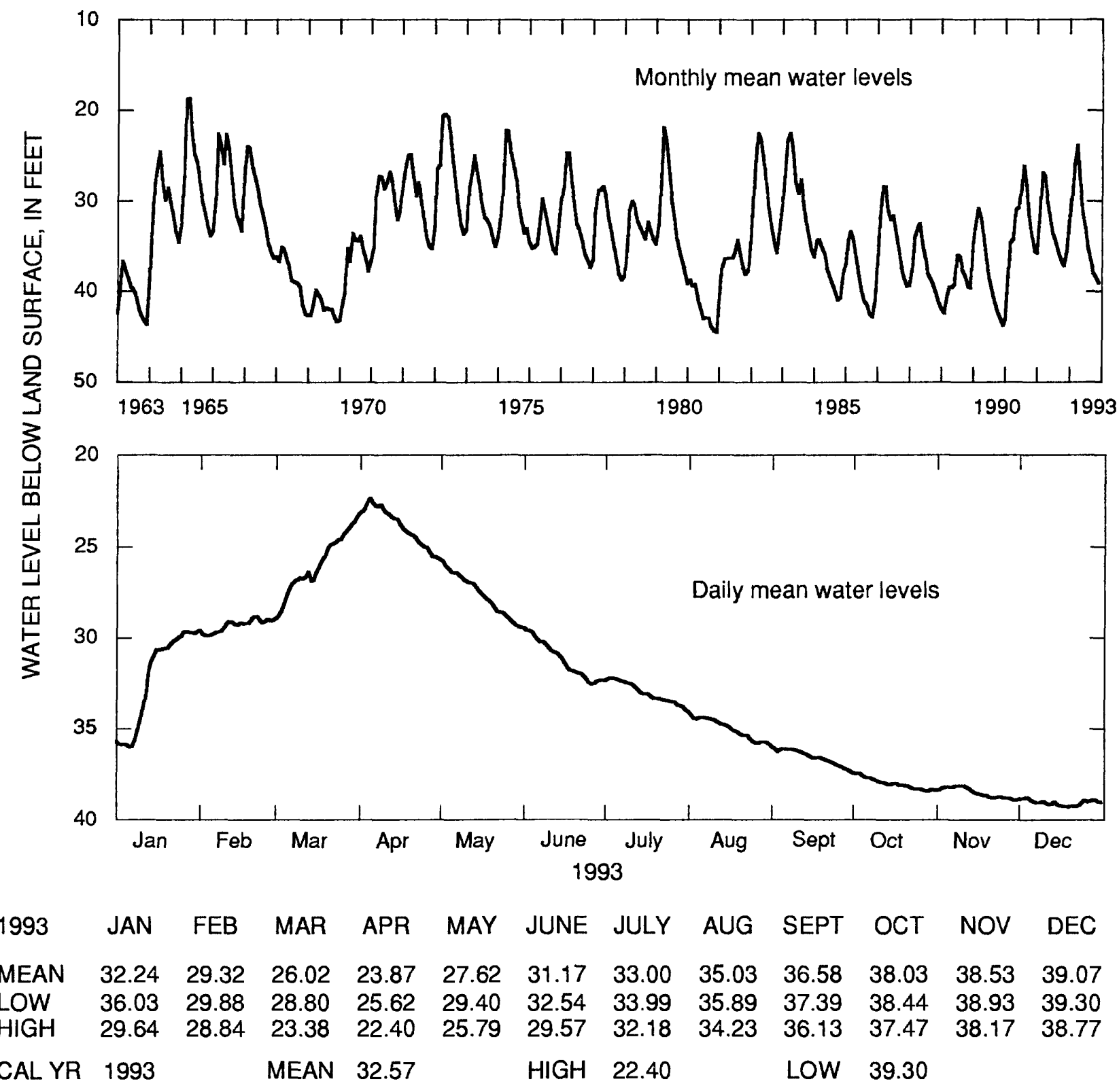

Figure 33.--Water level in observation well 13L003, Dougherty County. 
312127084065801 Local number, $13 \mathrm{~J} 004$.

LOCATION.--Lat $31^{\circ} 21^{\prime 2} 29^{\prime \prime}$ long 84 $06^{\prime} 57^{\prime \prime}$, Hydrologic Unit 03130008.

Owner: Aurora Dairy, Wright 1.

INSTRUMENTATION.--Digital recorder.

AQUIFER.--Upper Floridan aquifer.

WELL CHARACTERISTICS.--Drilled observation well, diameter 12 in., depth $208 \mathrm{ft}$, cased to $77 \mathrm{ft}$, open hole.

DATUM.--Altitude of land-surface datum is $200 \mathrm{ft}$.

REMARKS.--None.

PERIOD OF RECORD.--June 1978 to current year.

EXTREMES FOR PERIOD OF RECORD.--Highest water level, $36.67 \mathrm{ft}$ below land-surface datum, April 5, 1993;

lowest, $54.05 \mathrm{ft}$ below land-surface datum, December 25, 1990.

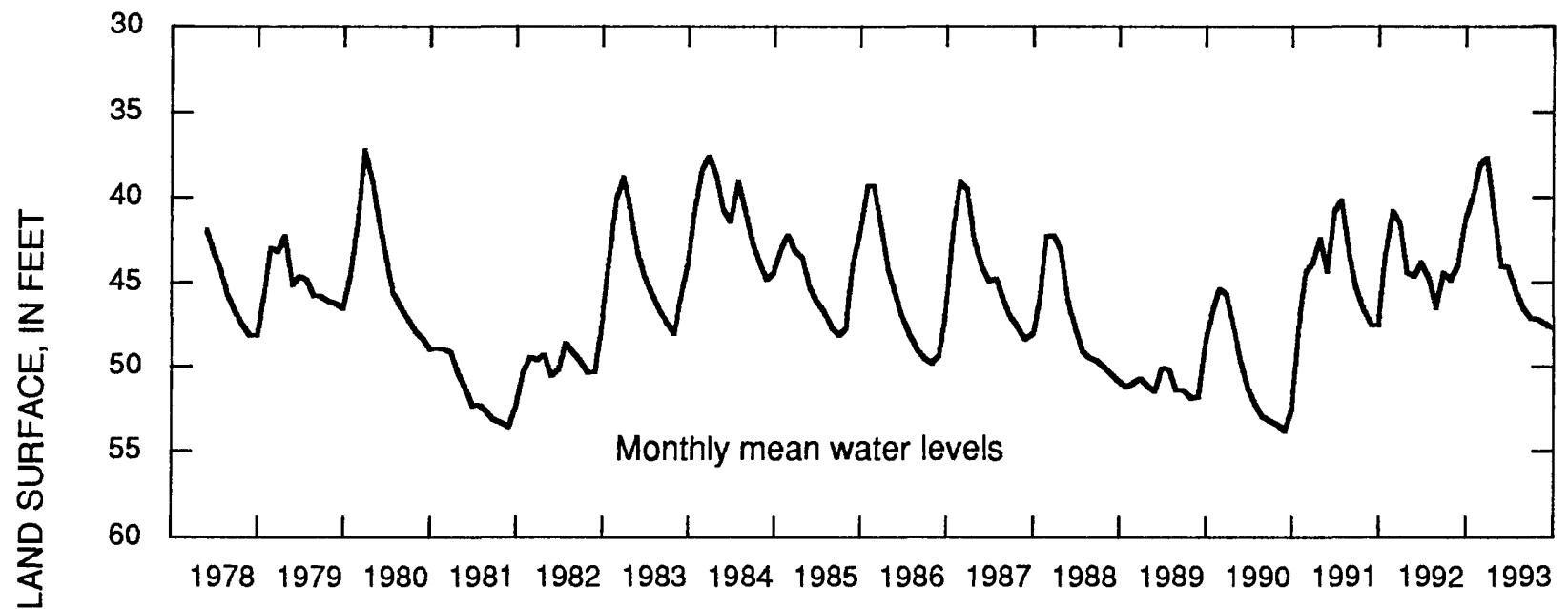

岂 35

1993

35

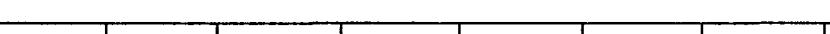

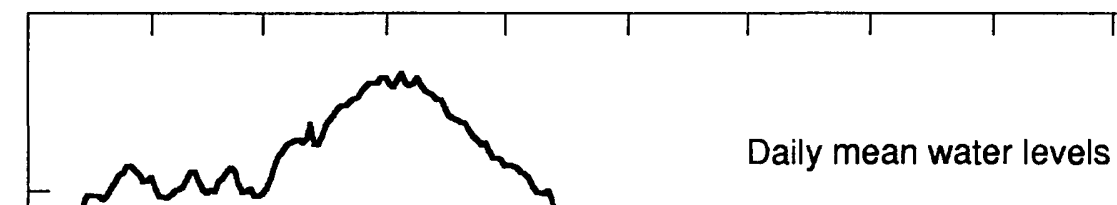

45

50

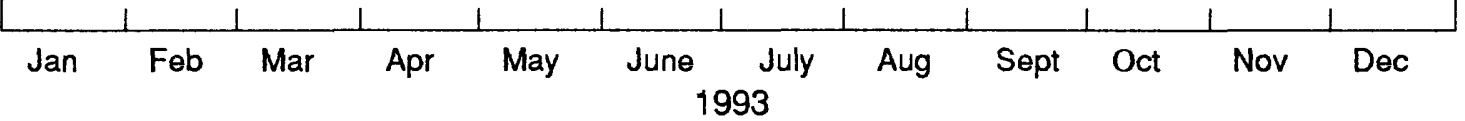

$\begin{array}{lllllllllllll}\text { MEAN } & 41.39 & 39.87 & 38.17 & 37.74 & 40.90 & 44.04 & 44.12 & 45.59 & 46.57 & 47.14 & 47.24 & 47.51 \\ \text { LOW } & 44.09 & 40.21 & 39.93 & 39.13 & 42.40 & 45.38 & 44.85 & 46.84 & 47.43 & 47.43 & 47.58 & 47.85 \\ \text { HIGH } & 39.28 & 39.34 & 36.78 & 36.67 & 39.27 & 42.11 & 43.62 & 44.85 & 46.11 & 46.80 & 46.99 & 47.07 \\ \text { CAL YR } & 1993 & & \text { MEAN } & 43.38 & & \text { HIGH } & 36.67 & & \text { LOW } & 47.85 & & \end{array}$

Figure 34.--Water level in observation well 13J004, Mitchell County. 
313146083491601 Local number, 15L020.

LOCATION.--Lat 31 '31'46", long 8349'16", Hydrologic Unit 03110204.

Owner: City of Sylvester.

INSTRUMENTATION.--Digital recorder.

AQUIFER.--Upper Floridan aquifer.

WELL CHARACTERISTICS.--Drilled unused municipal well, diameter $18 \mathrm{in}$., depth $450 \mathrm{ft}$, cased to $212 \mathrm{ft}$, open hole.

DATUM.--Altitude of land-surface datum is $420 \mathrm{ft}$.

REMARKS.--Well pumped and sounded July 19, 1978. Borehole geophysical survey conducted June 5, 1975.

PERIOD OF RECORD.--May 1972 to current year.

EXTREMES FOR PERIOD OF RECORD.--Highest water level, $191.5 \mathrm{ft}$ below land-surface datum, May 17, 1973; lowest, $207.07 \mathrm{ft}$ below land-surface datum, August 27, 1993.

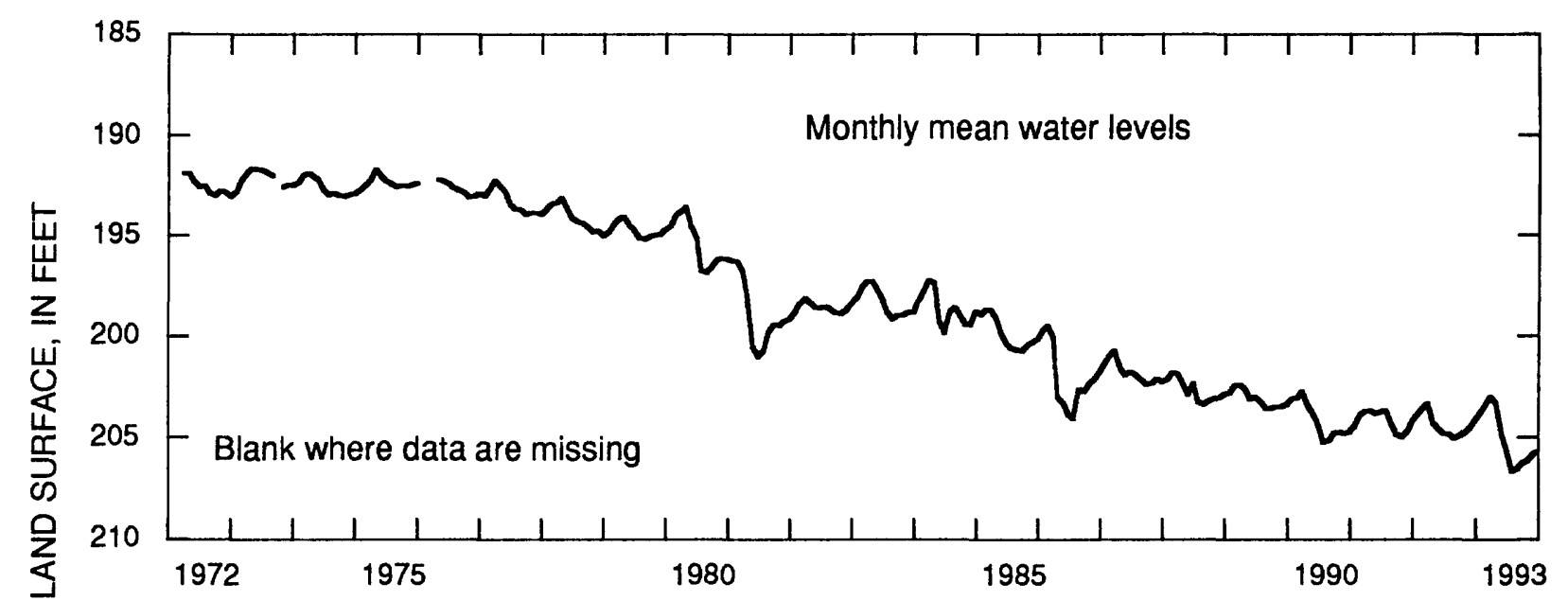

1993 JAN FEB MAR APR MAY JUNE JULY AUG SEPT OCT NOV DEC

MEAN 204.17203 .80203 .39202 .98203 .34204 .85205 .60206 .65206 .56206 .26206 .14205 .88

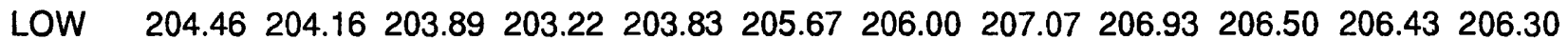

HIGH $\quad 203.87203 .49202 .79202 .74202 .95203 .70205 .32 \quad 206.15206 .30205 .74205 .79205 .50$

$\begin{array}{llllll}\text { CAL YR } 1993 & \text { MEAN 204.97 HIGH 202.74 LOW } 207.07\end{array}$

Figure 35.--Water level in observation well 15L020, Worth County. 


\section{South-central area}

The water level in the Upper Floridan aquifer in south-central Georgia was monitored in six wells in 1993; data from four of these wells (fig.27) are summarized in figures 36-39. Water levels in wells tapping the aquifer in this area are affected by variations in precipitation, evapotranspiration, and to a lesser degree, pumping (Krause, 1979). In the Valdosta area, water levels also are affected by streamflow (Krause, 1979). The water level generally is highest following the winter and spring rainy seasons, and lowest in the fall. The annual mean water levels in well $18 \mathrm{~K} 049$ in Tift County (fig. 36) and in well $18 \mathrm{H} 016$ in Cook County (fig. 37) were from about $0.6 \mathrm{ft} 1.3 \mathrm{ft}$ lower in 1993 than in 1992. A record-low daily mean water level was recorded in well $18 \mathrm{~K} 049$ (fig. 36) that was about $0.5 \mathrm{ft}$ lower than the previous record low.

The Upper Floridan aquifer receives recharge from the Withlacoochee River north of Valdosta where water from the river flows directly into sinkholes and large solution openings in the aquifer. In this area, increased precipitation and streamflow in winter and early spring result in higher ground-water levels. During most years, decreased precipitation and increased evapotranspiration in the summer results in lower streamflow and, correspondingly, lower ground-water levels. This relation is illustrated on the hydrographs for wells 19E009 (fig. 38) and 19F039 (fig. 39), where the annual mean water levels were about $3.2 \mathrm{ft}$ higher and about $5.4 \mathrm{ft}$ lower in 1993 than in 1992, respectively. 
312712082593301 Local number, $18 \mathrm{~K} 049$.

LOCATION.--Lat 31 $27^{\prime} 12^{\prime \prime}$, long 8259'33", Hydrologic Unit 03110203.

Owner: U.S. Geological Survey, test well 1.

INSTRUMENTATION.--Digital recorder.

AQUIFER.--Upper Floridan aquifer.

WELL CHARACTERISTICS.--Drilled observation well, diameter 6 in., depth $620 \mathrm{ft}$, cased to $270 \mathrm{ft}$, open hole.

DATUM.--Altitude of land-surface datum is $330 \mathrm{ft}$.

REMARKS.--Borehole geophysical survey conducted March 18, 1978. Water levels for periods of missing record, March 20 to April 22, May 13-26, and December 19-22, were estimated.

PERIOD OF RECORD.--March 1978 to current year.

EXTREMES FOR PERIOD OF RECORD.--Highest water level, $102.70 \mathrm{ft}$ below land-surface datum, May 14, 1978; lowest,

$126.71 \mathrm{ft}$ below land-surface datum, August 27, 1993.

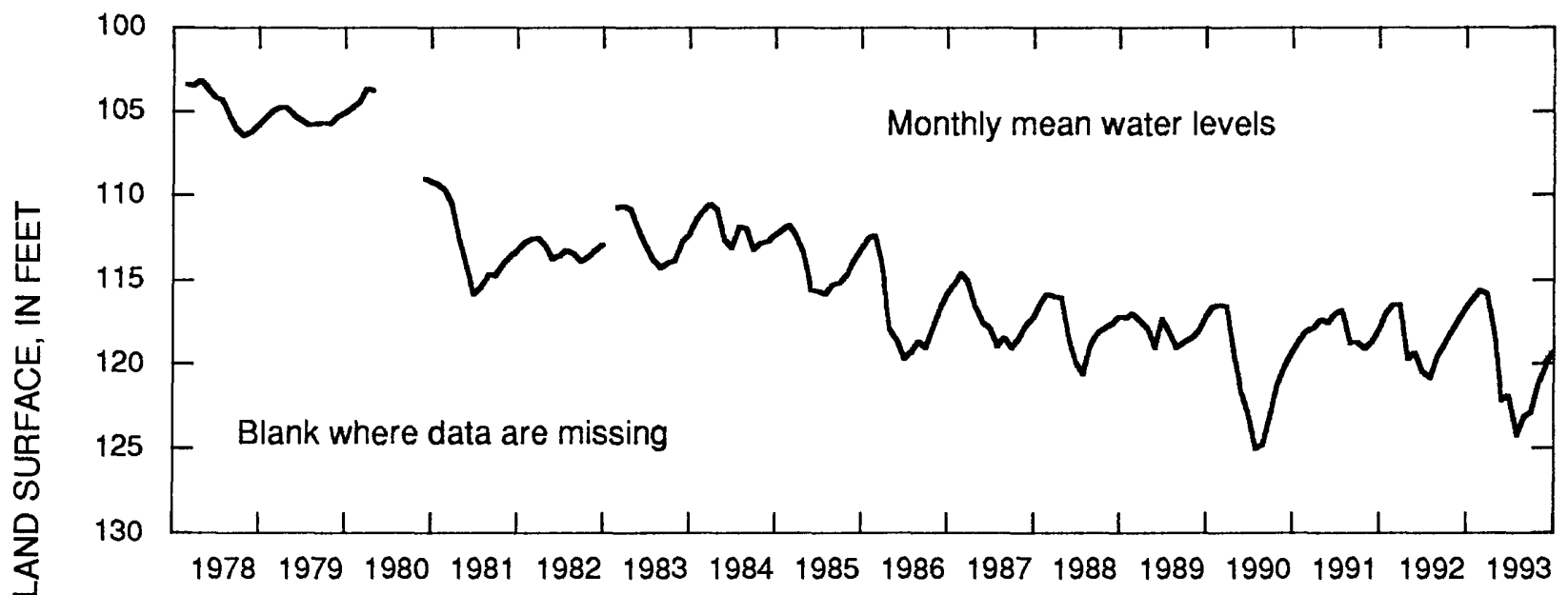

1993 JAN FEB MAR APR MAY JUNE JULY AUG SEPT OCT NOV DEC

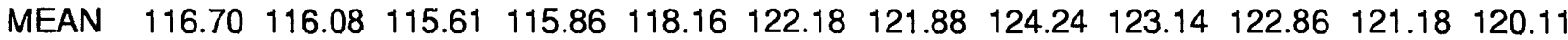

LOW $\quad \begin{array}{llllllllllll}117.05 & 116.56 & 115.99 & 116.75 & 120.14 & 124.83 & 123.19 & 126.71 & 124.40 & 123.59 & 122.16 & 120.72\end{array}$

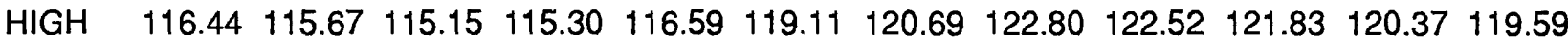

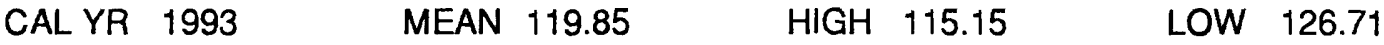

Figure 36.--Water level in observation well 18K049, Tift County. 
310813083260301 Local number, $18 \mathrm{H} 016$.

LOCATION.--Lat $31^{\circ} 08^{\prime} 13^{\prime \prime}$ long $83^{\circ} 26^{\prime} 03^{\prime \prime}$, Hydrologic Unit 03110203.

Owner: U.S. Geological Survey, Adel test well.

INSTRUMENTATION.--Digital recorder.

AQUIFER.--Upper Floridan aquifer.

WELL CHARACTERISTICS.--Drilled observation well, diameter 8 in., depth $865 \mathrm{ft}$, cased to $207 \mathrm{ft}$, open hole.

DATUM.--Altitude of land-surface datum is $241 \mathrm{ft}$.

REMARKS..-Well pumped July 19, 1978; water-quality sample collected at conclusion of pumping. Borehole geo-

physical survey conducted October 24, 1974. Water levels for period of missing record, August 1-31, were estimated.

PERIOD OF RECORD.--December 1964 to current year.

EXTREMES FOR PERIOD OF RECORD.--Highest water level, $163.34 \mathrm{ft}$ below land-surface datum, July 5, 1966; lowest,

$177.39 \mathrm{ft}$ below land-surface datum, October 8, 1990.

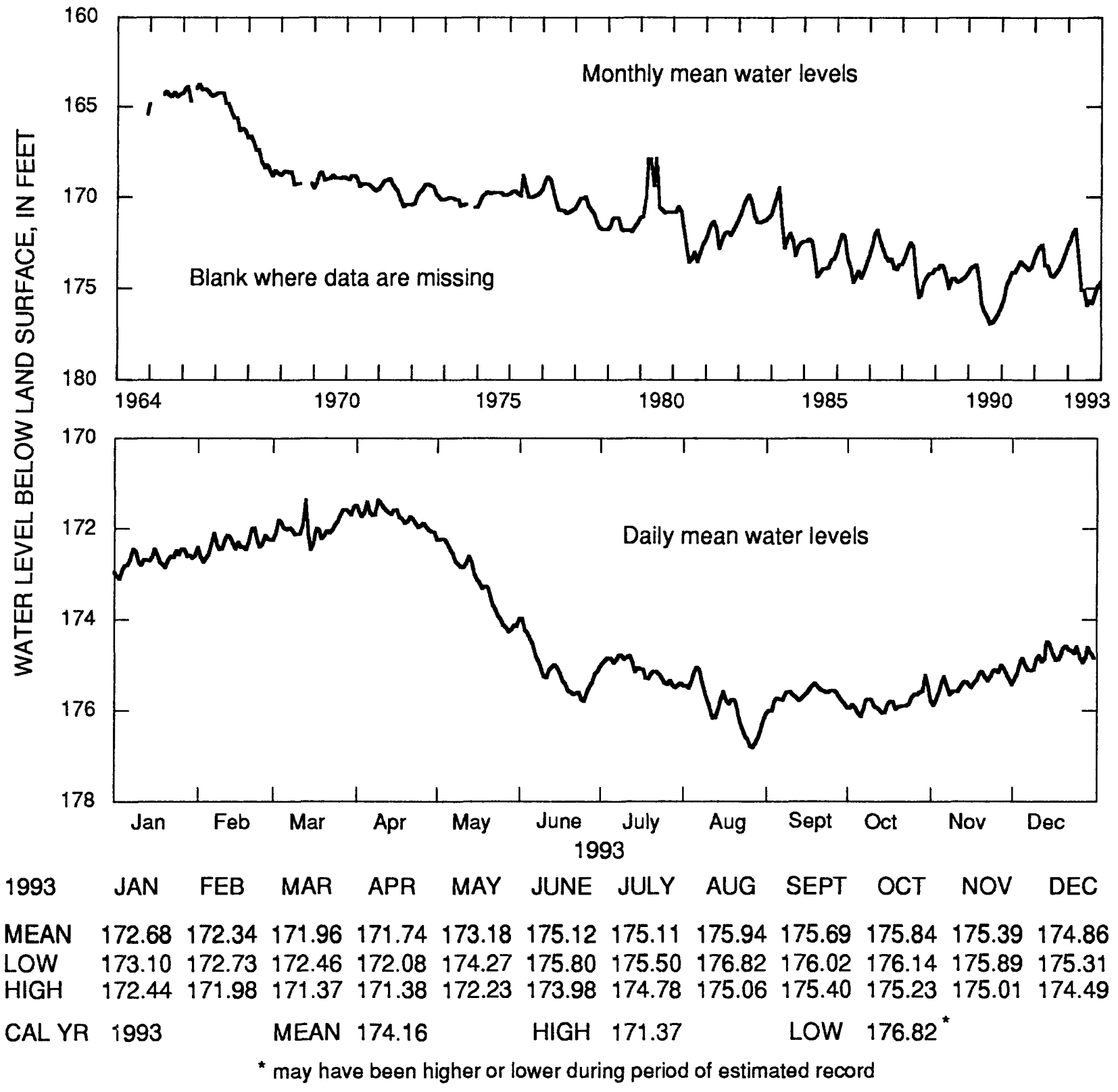

Figure 37.--Water level in observation well 18H016, Cook County. 
304949083165301 Local number, 19E009.

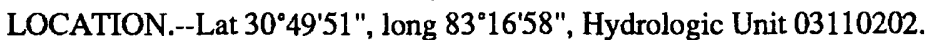

Owner: City of Valdosta.

INSTRUMENTATION.--Electronic data recorder.

AQUIFER.--Upper Floridan aquifer.

WELL CHARACTERISTICS.--Drilled unused municipal supply well, diameter $20 \mathrm{in}$., depth $342 \mathrm{ft}$, cased to $200 \mathrm{ft}$, open hole.

DATUM.--Altitude of land-surface datum is $217 \mathrm{ft}$.

REMARKS.--Well pumped July 18, 1978; water-quality sample collected at conclusion of pumping. Borehole geophysical survey conducted April 11, 1963. Water levels for period of missing record, January 15-21, were estimated.

PERIOD OF RECORD.--February 1957 to current year.

EXTREMES FOR PERIOD OF RECORD.--Highest water level, $112.69 \mathrm{ft}$ below land-surface datum, March 9, 1964; lowest, $151.79 \mathrm{ft}$ below land-surface datum, September 19, 1990.

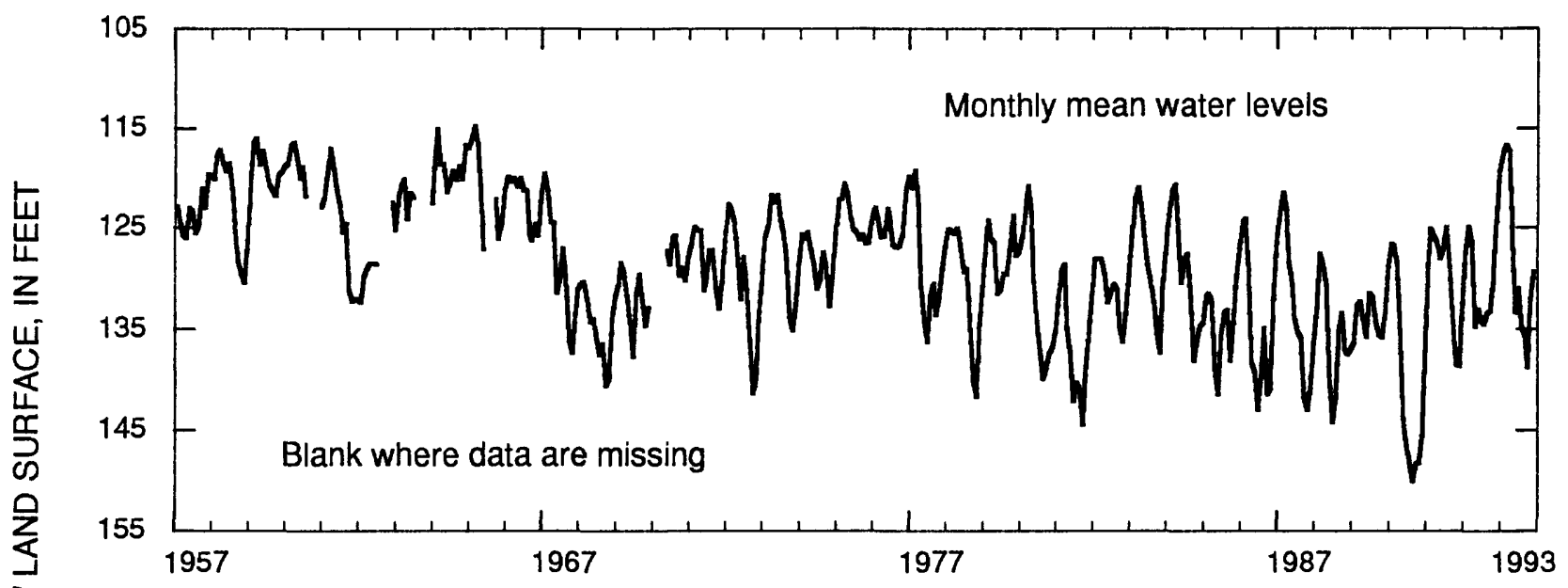

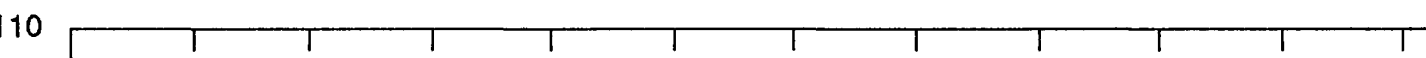

엄

Daily mean water levels

150

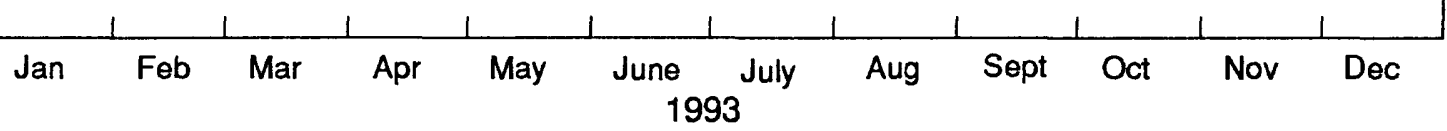

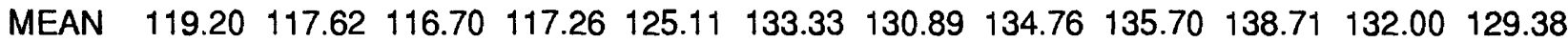

LOW $\quad \begin{array}{llllllllllll}121.65 & 118.04 & 117.81 & 119.79 & 130.31 & 136.01 & 132.78 & 137.03 & 136.82 & 139.88 & 135.06 & 130.47\end{array}$

HIGH $\quad 117.44 \quad 117.19 \quad 115.70 \quad 115.55 \quad 120.13 \quad 130.37 \quad 128.96 \quad 132.55 \quad 134.30 \quad 136.26 \quad 130.15 \quad 127.94$

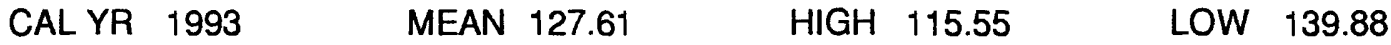

Figure 38.--Water level in observation well 19E009, Lowndes County. 
305241083154401 Local number, 19F039.

LOCATION.--Lat 30'52'41", long 83¹5'46", Hydrologic Unit 03110203.

Owner: City of Valdosta, well 8.

INSTRUMENTATION.--Digital recorder.

AQUIFER.--Upper Floridan aquifer.

WELL CHARACTERISTICS.--Drilled unused municipal supply well, diameter $16 \mathrm{in}$., depth $450 \mathrm{ft}$, cased to $350 \mathrm{ft}$, open hole.

DATUM.--Altitude of land-surface datum is $222 \mathrm{ft}$.

REMARKS.--Water levels for period of missing record, May 1 to June 22, was estimated.

PERIOD OF RECORD.--February 1979 to current year.

EXTREMES FOR PERIOD OF RECORD.--Highest water level, $114.28 \mathrm{ft}$ below land-surface datum, April 9, 1984; lowest,

$151.28 \mathrm{ft}$ below land-surface datum, October 9, 1990.

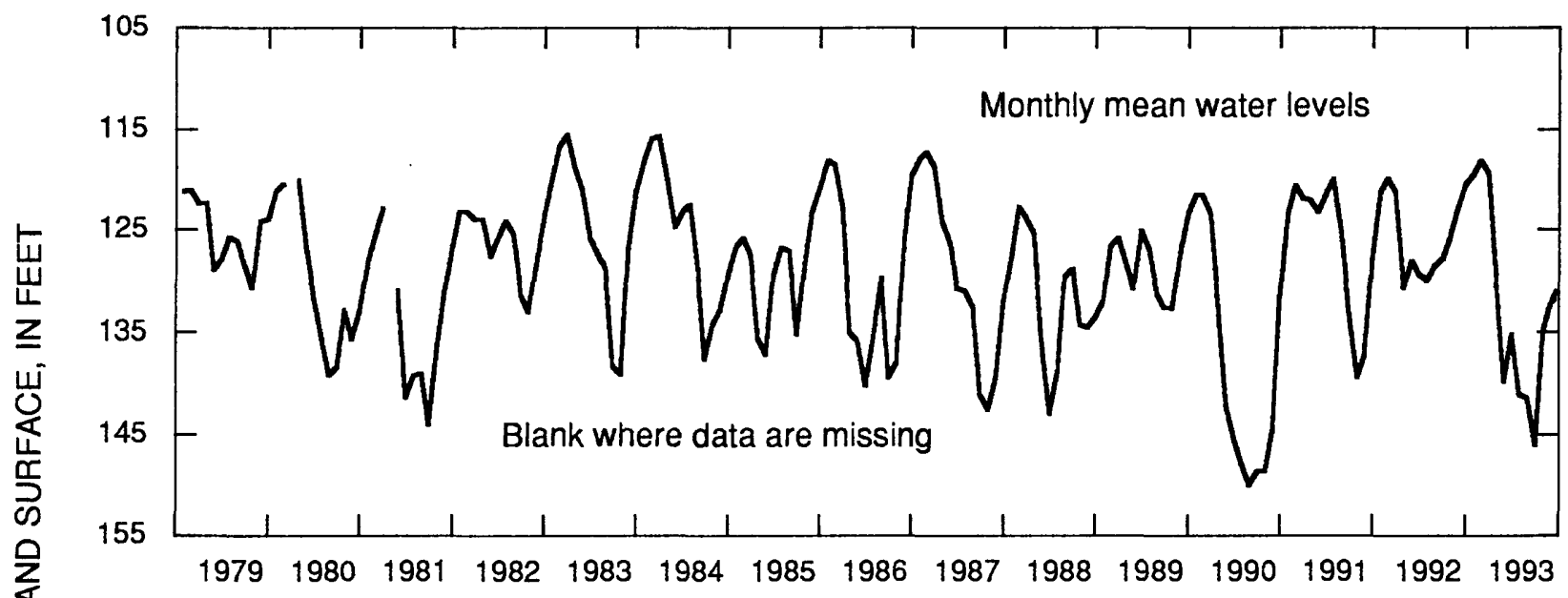

1993 JAN FEB MAR APR MAY JUNE JULY AUG SEPT OCT NOV DEC

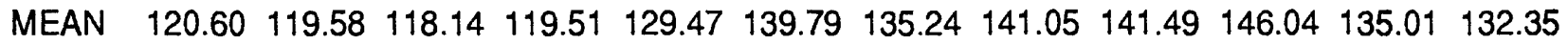
LOW $\quad \begin{array}{lllllllllllll}124.03 & 120.62 & 119.96 & 122.75 & 135.96 & 143.74 & 138.90 & 144.47 & 143.61 & 147.54 & 139.63 & 133.77\end{array}$ HIGH $\quad \begin{array}{llllllllllll}118.80 & 118.71 & 116.72 & 116.80 & 123.27 & 133.55 & 131.94 & 137.75 & 138.46 & 143.75 & 132.84 & 130.09\end{array}$ $\begin{array}{lllllll}\text { CAL YR } 1993 & \text { MEAN } & 131.59 & \text { HIGH } & 116.71 & \text { LOW } & 147.54\end{array}$

Figure 39.--Water level in observation well 19F039, Lowndes County. 


\section{East-central area}

The water level in the Upper Floridan aquifer in east-central Georgia was monitored in 18 wells in 1993; data for three of these wells (fig. 27) are summarized in figures 40-42. Well 21T001 (fig. 40) in Laurens County is located near the recharge area for the Upper Floridan aquifer, and the water level in this well (fig. 40) responds primarily to seasonal fluctuations in precipitation. The annual mean water level in this well was about $3.6 \mathrm{ft}$ lower in 1993 than in 1992. The 1993 annual mean water levels in wells 26R001 in Montgomery County (fig. 41) and well 25Q001 in Toombs County (fig. 42) were from 0.6 to $0.8 \mathrm{ft}$ lower than in 1992. 
322652083033001 Local number, $21 \mathrm{~T} 001$.

LOCATION.--Lat 32²7'06", long 8303'28", Hydrologic Unit 03070102.

Owner: Danny Hogan.

INSTRUMENTATION.--Digital recorder.

AQUIFER.--Upper Floridan aquifer.

WELL CHARACTERISTICS.--Drilled unused supply well, diameter 4 in., depth $123 \mathrm{ft}$, cased to $89 \mathrm{ft}$, open hole.

DATUM.--Altitude of land-surface datum is $259 \mathrm{ft}$.

REMARKS.--Borehole geophysical survey conducted November 1973. Well pumped and sampled by Georgia Geologic

Survey, December 8, 1992. Water levels for periods of missing record, August 5-7, 10-18, and September 13-18, were estimated. PERIOD OF RECORD.--March 1964 to current year.

EXTREMES FOR PERIOD OF RECORD.--Highest water level, $23.62 \mathrm{ft}$ below land-surface datum, January 26, 1987; lowest, $39.58 \mathrm{ft}$ below land-surface datum, November 12, 1968.

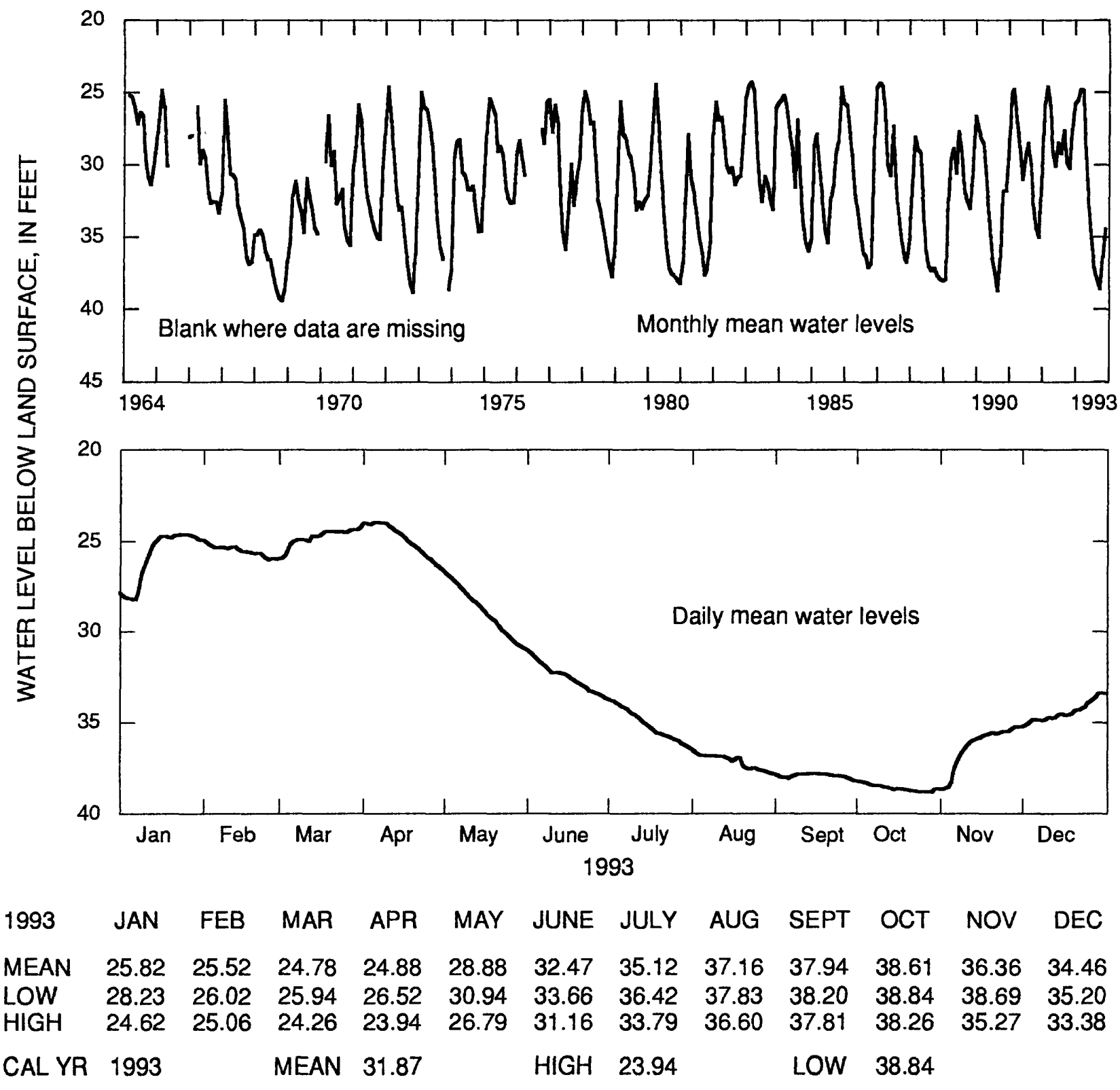

Figure 40.--Water level in observation well 21T001, Laurens County. 
320226082301101 Local number, $25 \mathrm{Q} 001$.

LOCATION.--Lat $32^{\circ} 02^{\prime} 25^{\prime \prime}$, long 82³0'05", Hydrologic Unit 03070106.

Owner: Montgomery County Board of Education.

INSTRUMENTATION.--Digital recorder.

AQUIFER.--Upper Floridan aquifer.

WELL CHARACTERISTICS.--Drilled unused supply well, diameter 6 in., depth $536 \mathrm{ft}$, cased to $421 \mathrm{ft}$, open hole.

DATUM.--Altitude of land-surface datum is $190 \mathrm{ft}$.

REMARKS.--Borehole geophysical survey conducted April 22, 1966.

PERIOD OF RECORD.--June 1966 to current year.

EXTREMES FOR PERIOD OF RECORD.--Highest water level, $64.13 \mathrm{ft}$ below land-surface datum, June 10, 1966; lowest,

$82.94 \mathrm{ft}$ below land-surface datum, October 7, 1990.

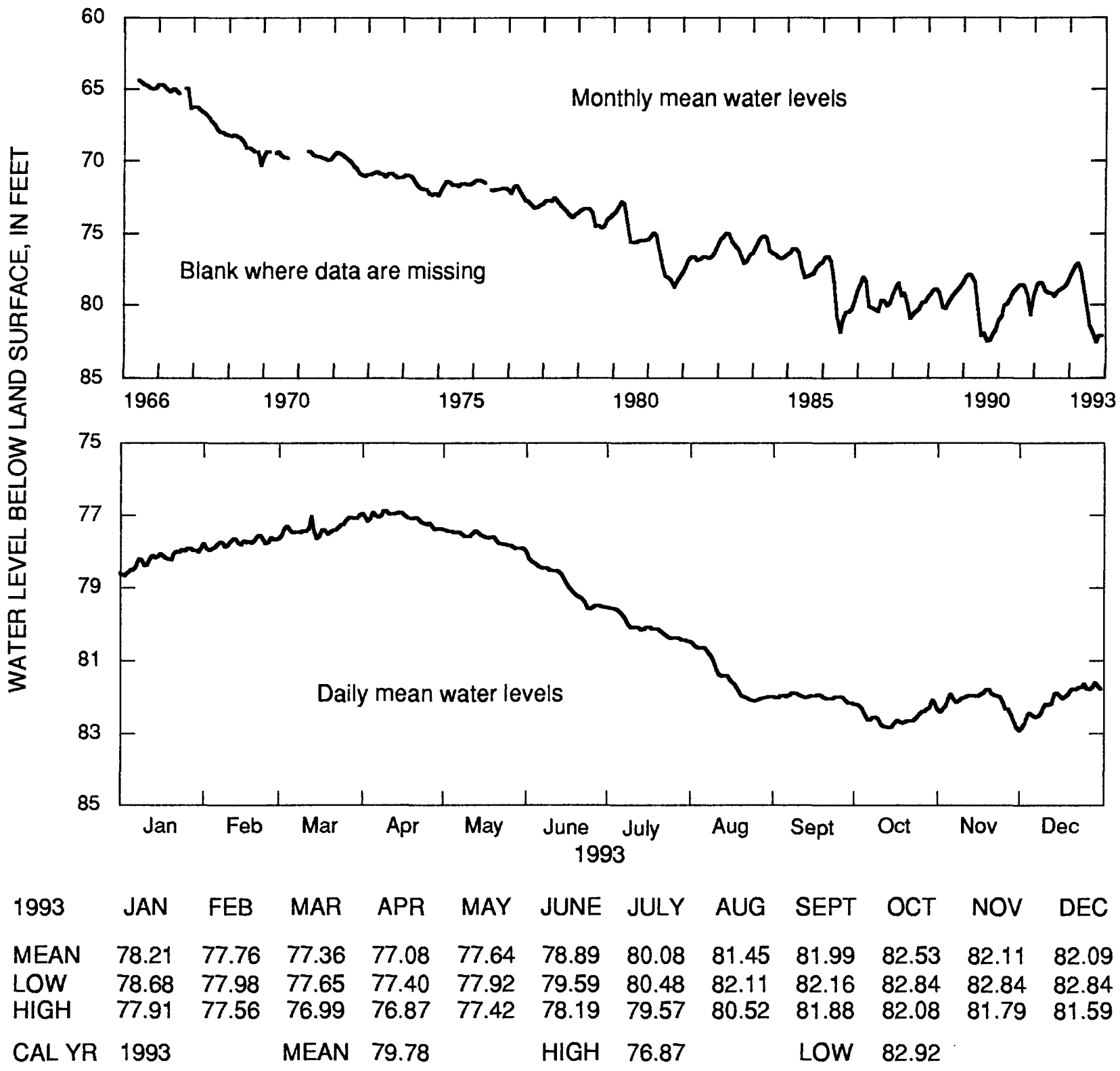

Figure 41.--Water level in observation well 25Q001, Montgomery County. 
321302082243601 Local number, $26 \mathrm{R} 001$.

LOCATION.--Lat $32^{\circ} 13^{\prime} 02^{\prime \prime}$, long 82²4'36", Hydrologic Unit 03070107.

Owner: City of Vidalia, well 2.

INSTRUMENTATION.--Digital recorder.

AQUFER.--Upper Floridan aquifer.

WELL CHARACTERISTICS.--Drilled municipal supply well, diameter $12 \mathrm{in}$., depth 1,000 ft, cased to $720 \mathrm{ft}$, open hole.

DATUM.--Altitude of land-surface datum is $285 \mathrm{ft}$.

REMARKS.--None.

PERIOD OF RECORD.--April 1974 to current.

EXTREMES FOR PERIOD OF RECORD.--Highest water level, $151.64 \mathrm{ft}$ below land-surface datum, April 15, 1974; lowest, $171.94 \mathrm{ft}$ below land-surface datum, July 10, 1986.

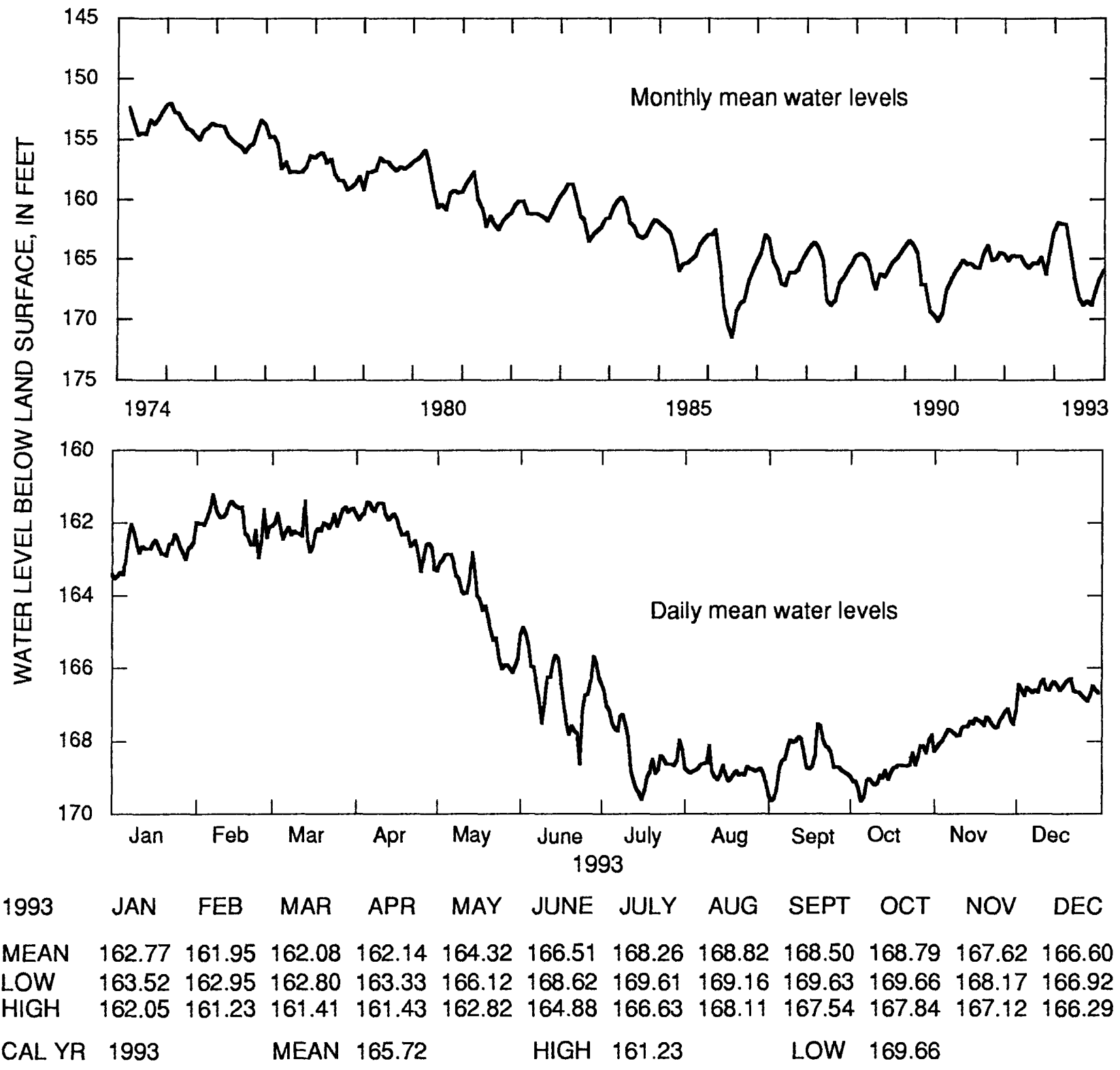

Figure 42.--Water level in observation well 26R001, Toombs County. 


\section{Coastal area}

The water level in the Upper Floridan aquifer in the coastal area was monitored in 22 wells in 1993; data from 16 of these wells (fig. 43) are summarized in figures 44-59. Because the Upper Floridan aquifer in this area is deeply buried and far from the outcrop area, the ground-water level is influenced primarily by pumping and not by recharge from local precipitation (Clarke and others, 1990).

The coastal area is divided into the following four subareas on the basis of major pumping centers (1) the Savannah subarea; (2) the Jesup-Doctortown subarea; (3) the Brunswick subarea; and (4) the St Marys-Okefenokee Swamp subarea (fig. 43). Within a subarea, hydrographs for wells have similar waterlevel changes. Industrial shutdowns, during which the amount of ground water withdrawn is greatly reduced, are indicated by sharp water-level rises on hydrographs from wells located in the same hydrologic subarea. 


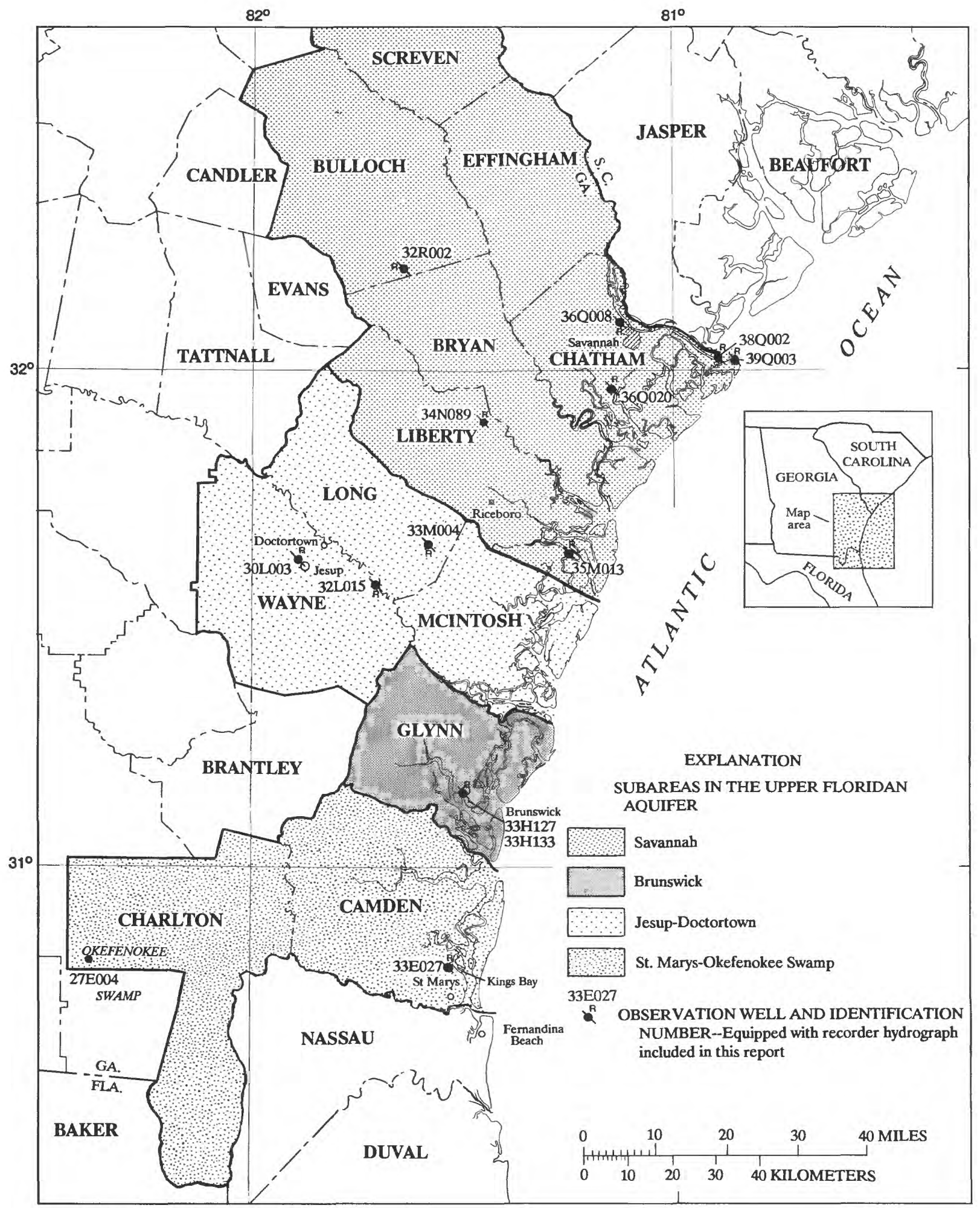

Base from U.S. Geological Survey State base maps

Figure 43.--Subareas and locations of observation wells completed in the Upper Floridan aquifer in the coastal area. 


\section{Savannah subarea}

The water level in the Upper Floridan aquifer in the Savannah subarea was monitored in 11 wells in 1993; data from 7 of these wells (fig. 43) are summarized in figures 44-50. In this subarea, the water level in the Upper Floridan aquifer mainly is affected by pumping for municipal and industrial uses, and as a result of this pumping, a cone of depression has developed in the potentiometric surface at Savannah (Peck, 1991).

Hydrographs for observation wells near the center of pumping in Savannah and in outlying areas illustrate the effects of pumping on the ground-water levels. The 1993 annual mean water levels in wells near the area of the cone of depression at Savannah (figs. 44-47) were from about the same to $5.3 \mathrm{ft}$ lower than in 1992. During 1993, the annual mean water levels in wells in the outlying areas (figs. 48-50) were from $0.4 \mathrm{ft}$ lower to $0.8 \mathrm{ft}$ higher than in 1992 . 
320530081085001 Local number, $36 \mathrm{Q} 008$.

LOCATION.--Lat $32^{\circ} 05^{\prime} 30^{\prime \prime}$, long $81^{\circ} 08^{\prime} 50^{\prime \prime}$, Hydrologic Unit 03060204.

Owner: Layne-Atlantic Co.

INSTRUMENTATION.--Analog recorder.

AQUIFER.--Upper Floridan aquifer.

WELL CHARACTERISTICS.--Drilled unused supply well, diameter 4 in., depth $406 \mathrm{ft}$, cased to $250 \mathrm{ft}$, open hole.

DATUM.--Altitude of land-surface datum is $9.91 \mathrm{ft}$.

REMARKS.--Water levels for periods of missing record, January 17-25, March 23 to April 1, and April 4-13, were estimated. PERIOD OF RECORD.--February 1954 to current year.

EXTREMES FOR PERIOD OF RECORD.--Highest water level, $49.17 \mathrm{ft}$ below land-surface datum, July 11, 1954; lowest, $124.40 \mathrm{ft}$ below land-surface datum, August 30, 1980.
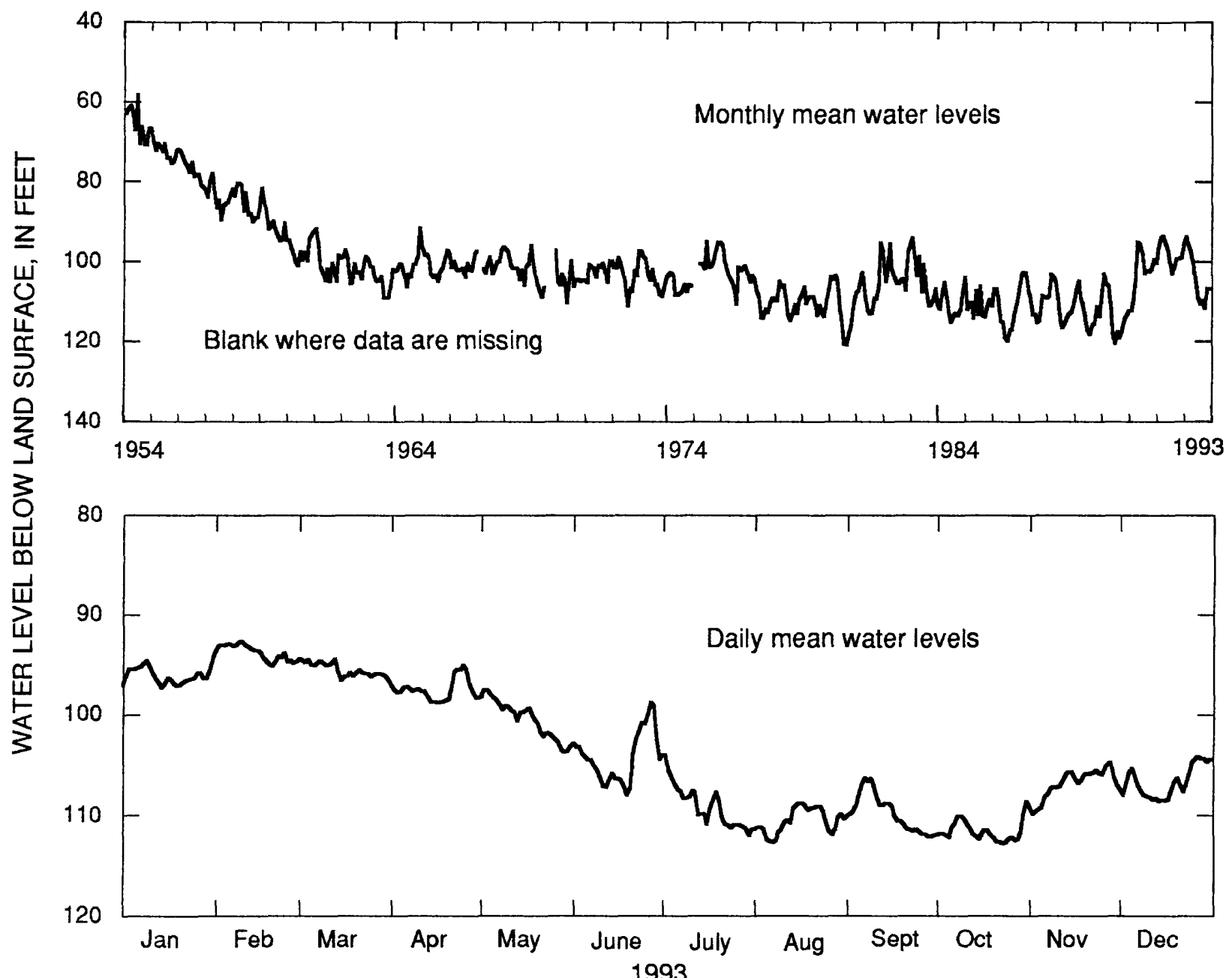

1993 JAN FEB MAR APR MAY JUNE JULY AUG SEPT OCT NOV DEC

$\begin{array}{lllllllllllll}\text { MEAN } & 96.07 & 93.74 & 95.45 & 97.47 & 100.45 & 104.20 & 108.97 & 110.55 & 109.72 & 111.58 & 106.80 & 106.72\end{array}$

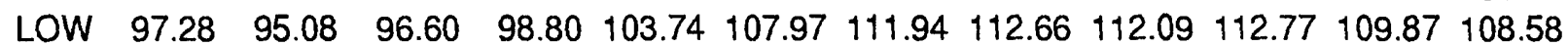

$\begin{array}{lllllllllllll}\text { HIGH } & 94.28 & 92.63 & 94.35 & 94.99 & 97.44 & 98.75 & 104.09 & 108.78 & 106.26 & 108.63 & 104.73 & 104.21\end{array}$

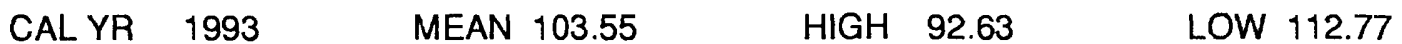

Figure 44.--Water level in observation well 36Q008, Chatham County. 
320021081124801 Local number, 36Q020.

LOCATION.--Lat $32^{\circ} 00^{\prime} 18^{\prime \prime}$, long $81^{\circ} 12^{\prime} 48^{\prime \prime}$, Hydrologic Unit 03060204.

Owner: H. J. Morrison.

INSTRUMENTATION.--Digital recorder.

AQUIFER.--Upper Floridan aquifer.

WELL CHARACTERISTICS.--Drilled unused supply well, diameter 3 in., depth $365 \mathrm{ft}$, cased to $330 \mathrm{ft}$, open hole.

DATUM.--Altitude of land-surface datum is $13 \mathrm{ft}$.

REMARKS.--Borehole geophysical survey, May 7, 1985. Water levels for periods of missing record, January 17-24, April 3-20, and August 26 to October 25, were estimated.

PERIOD OF RECORD.--March 1958 to current year.

EXTREMES FOR PERIOD OF RECORD.--Highest water level, $17.66 \mathrm{ft}$ below land-surface datum, June 28, 1958; lowest, recorded, $58.56 \mathrm{ft}$ below land-surface datum, July 12,1990 , but may have been lower during period of missing record, July 13-22, 1990.
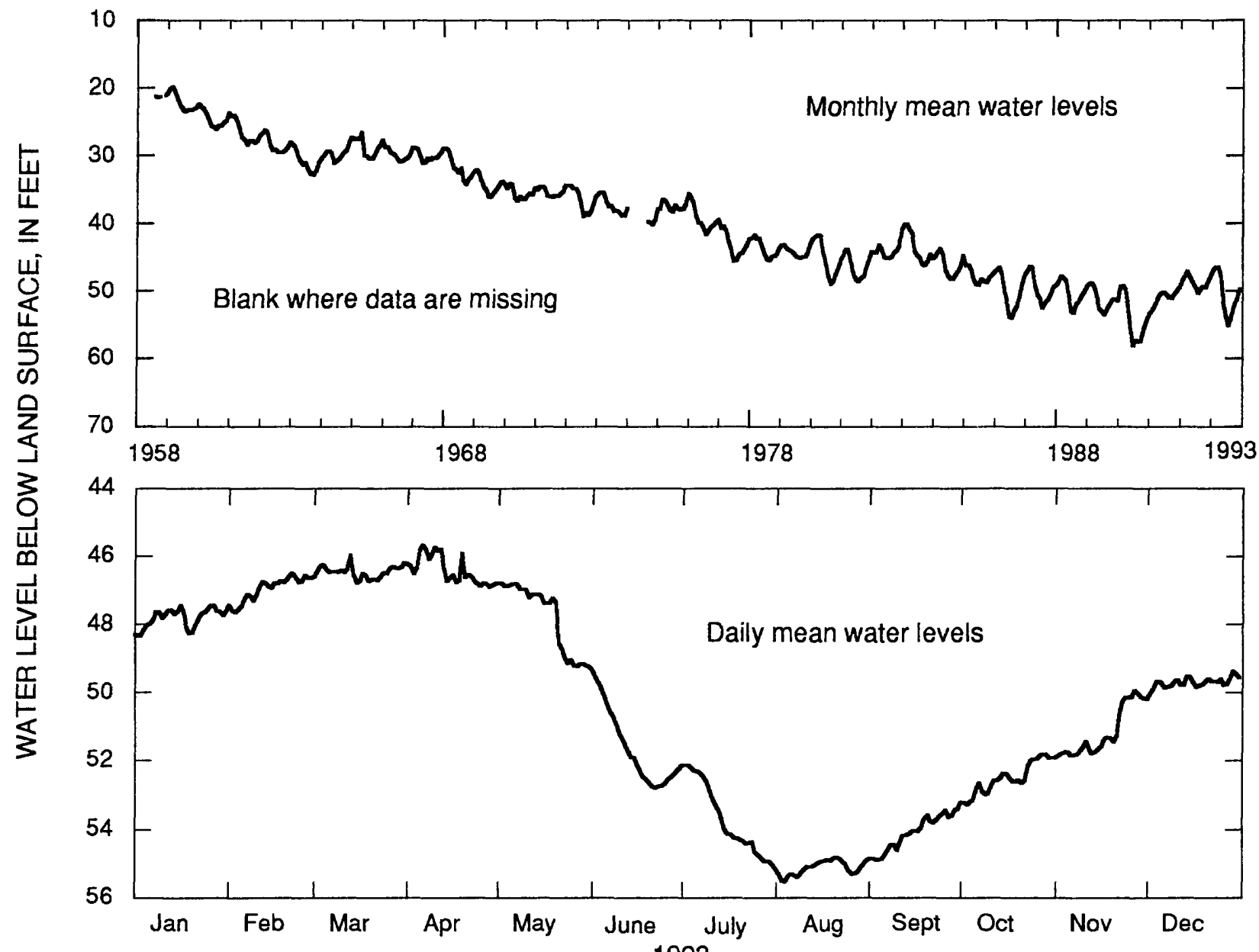

$\begin{array}{lcccccccccccc}1993 & \text { JAN } & \text { FEB } & \text { MAR } & \text { APR } & \text { MAY } & \text { JUNE } & \text { JULY } & \text { AUG } & \text { SEPT } & \text { OCT } & \text { NOV } & \text { DEC } \\ \text { MEAN } & 47.82 & 46.98 & 46.48 & 46.42 & 47.78 & 51.63 & 53.68 & 55.13 & 54.12 & 52.54 & 51.22 & 49.72 \\ \text { LOW } & 48.36 & 47.66 & 46.81 & 46.92 & 49.27 & 52.82 & 55.06 & 55.54 & 54.89 & 53.29 & 51.88 & 50.06 \\ \text { HIGH } & 47.45 & 46.53 & 45.98 & 45.68 & 46.82 & 49.55 & 52.14 & 54.81 & 53.42 & 51.82 & 49.94 & 49.38 \\ \text { CAL YR } & 1993 & & \text { MEAN } & 50.32 & & \text { HIGH } & 45.68^{*} & & \text { LOW } & 55.54 & & \end{array}$

* may have been higher or lower during period of estimated record

Figure 45.--Water level in observation well 36Q020, Chatham County. 
320202080541201 Local number, $38 \mathrm{Q} 002$.

LOCATION.--Lat $32^{\circ} 02^{\prime} 01^{\prime \prime}$, long 80'54'11", Hydrologic Unit 03060204.

Owner: U.S. Department of the Interior, National Park Service, test well 6.

INSTRUMENTATION.--Digital recorder.

AQUIFER.--Upper Floridan aquifer.

WELL CHARACTERISTICS.--Drilled observation well, diameter 8 in., depth $348 \mathrm{ft}$, cased to $110 \mathrm{ft}$, open hole.

DATUM.--Altitude of land-surface datum is $8.0 \mathrm{ft}$.

REMARKS.--Borehole geophysical survey conducted June 16, 1961. Water levels for periods of missing record, November 5-9 and 17-22, were estimated.

PERIOD OF RECORD.--February 1956 to current year.

EXTREMES FOR PERIOD OF RECORD.--Highest water level, $16.00 \mathrm{ft}$ below land-surface datum, March 5, 1956; lowest, $40.69 \mathrm{ft}$ below land-surface datum, July 16, 1990.

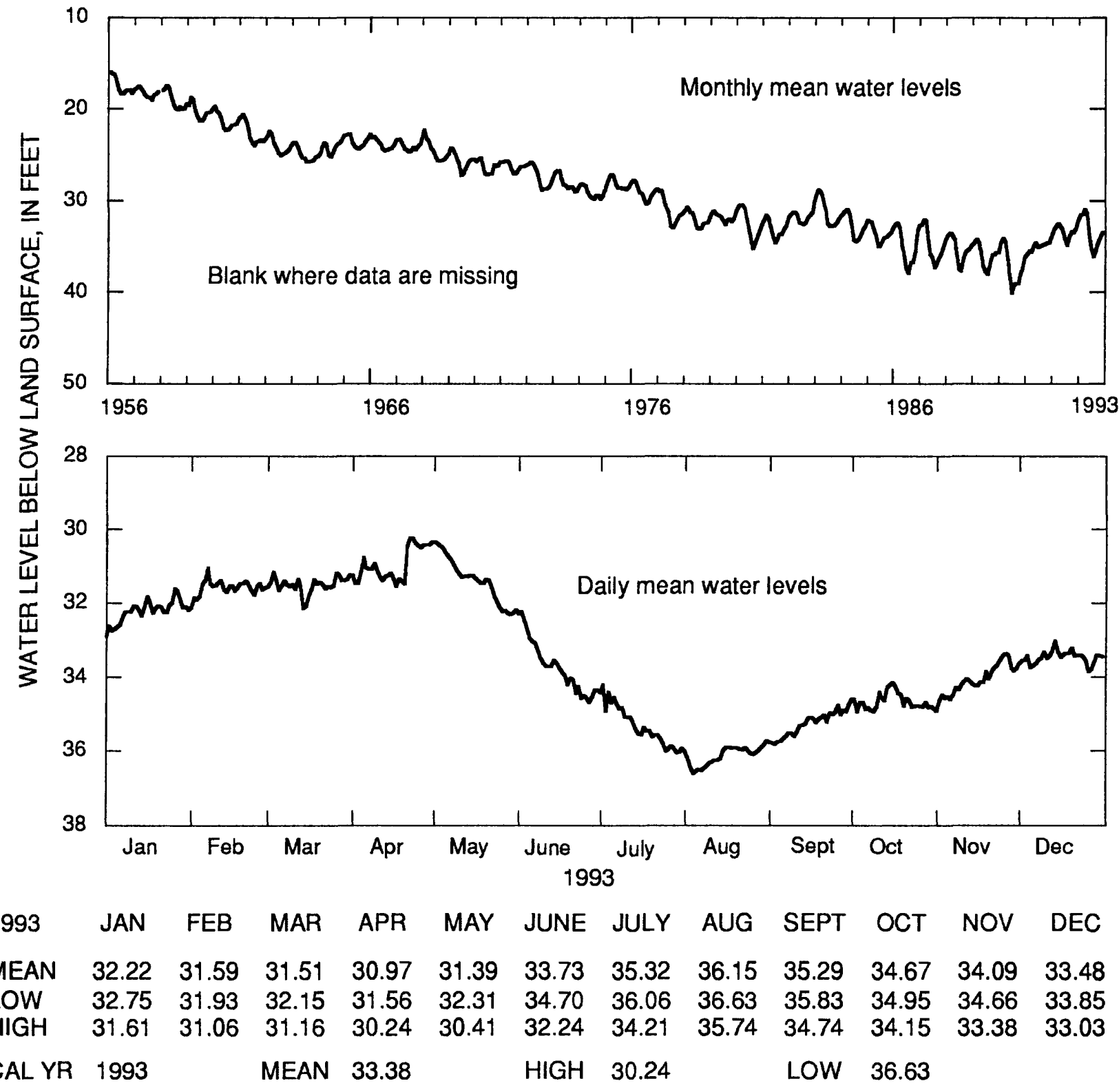

Figure 46.--Water level in observation well 38Q002, Chatham County. 
320122080510204 Local number, 39 Q003.

LOCATION.--Lat $32^{\circ} 01^{\prime 22} 2^{\prime \prime}$ long 80 $51^{\prime} 01^{\prime \prime}$, Hydrologic Unit 03060204.

Owner: U.S. Geological Survey, test well 7.

INSTRUMENTATION.--Digital recorder.

AQUIFER.--Upper Floridan aquifer.

WELL CHARACTERISTICS.--Drilled observation well, diameter $10 \mathrm{in}$., depth $600 \mathrm{ft}$, cased to $129 \mathrm{ft}$, open hole.

DATUM.--Altitude of land-surface datum is $7.0 \mathrm{ft}$.

REMARKS.--Borehole geophysical survey conducted January 24, 1962.

PERIOD OF RECORD.--May 1962 to current year; continuous record, September 1965 to current year.

EXTREMES FOR PERIOD OF RECORD.--Highest water level, $17.80 \mathrm{ft}$ below land-surface datum, April 11, 1963; lowest, $36.07 \mathrm{ft}$ below land-surface datum, July 11-12, 1990.

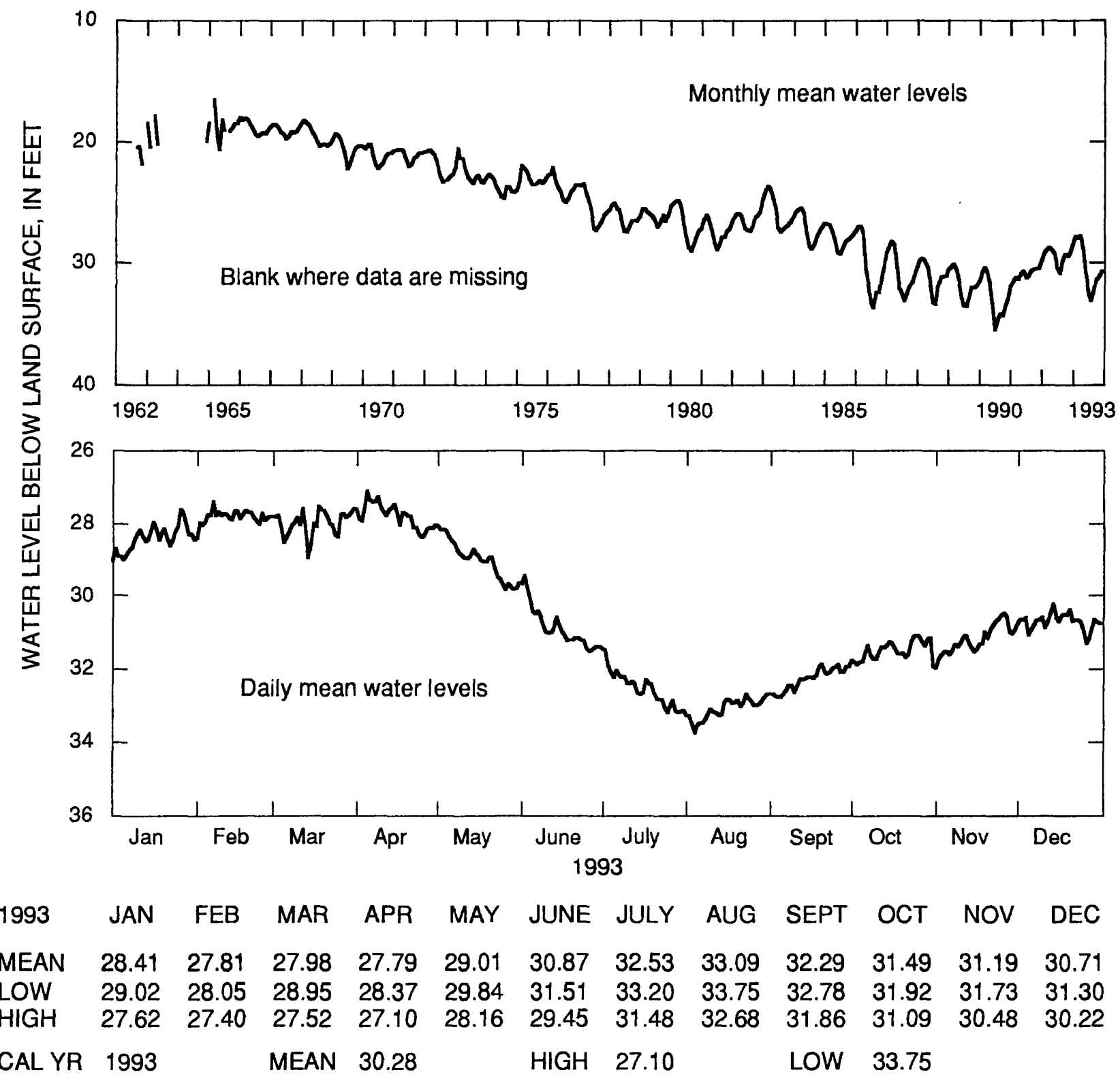

Figure 47.--Water level in observation well 39Q003, Chatham County. 
321240081411501 Local number, 32R002.

LOCATION.--Lat 32¹2'40", long 81 ${ }^{\circ} 41^{\prime} 15^{\prime \prime}$, Hydrologic Unit 03060202.

Owner: Georgia Geologic Survey, Bulloch South test well 1.

INSTRUMENTATION.--Digital recorder.

AQUIFER.--Upper Floridan aquifer.

WELL CHARACTERISTICS.--Drilled observation well, diameter 6 in., depth $804 \mathrm{ft}$, cased to $420 \mathrm{ft}$, open hole.

DATUM.--Altitude of land-surface datum is $120 \mathrm{ft}$.

REMARKS.--Borehole geophysical survey and well sounded August 1982.

PERIOD OF RECORD.--February 1983 to current year.

EXTREMES FOR PERIOD OF RECORD.--Highest water level, $85.08 \mathrm{ft}$ below land-surface datum, April 24, 1983; lowest, $95.94 \mathrm{ft}$ below land-surface datum, October 8, 1990.

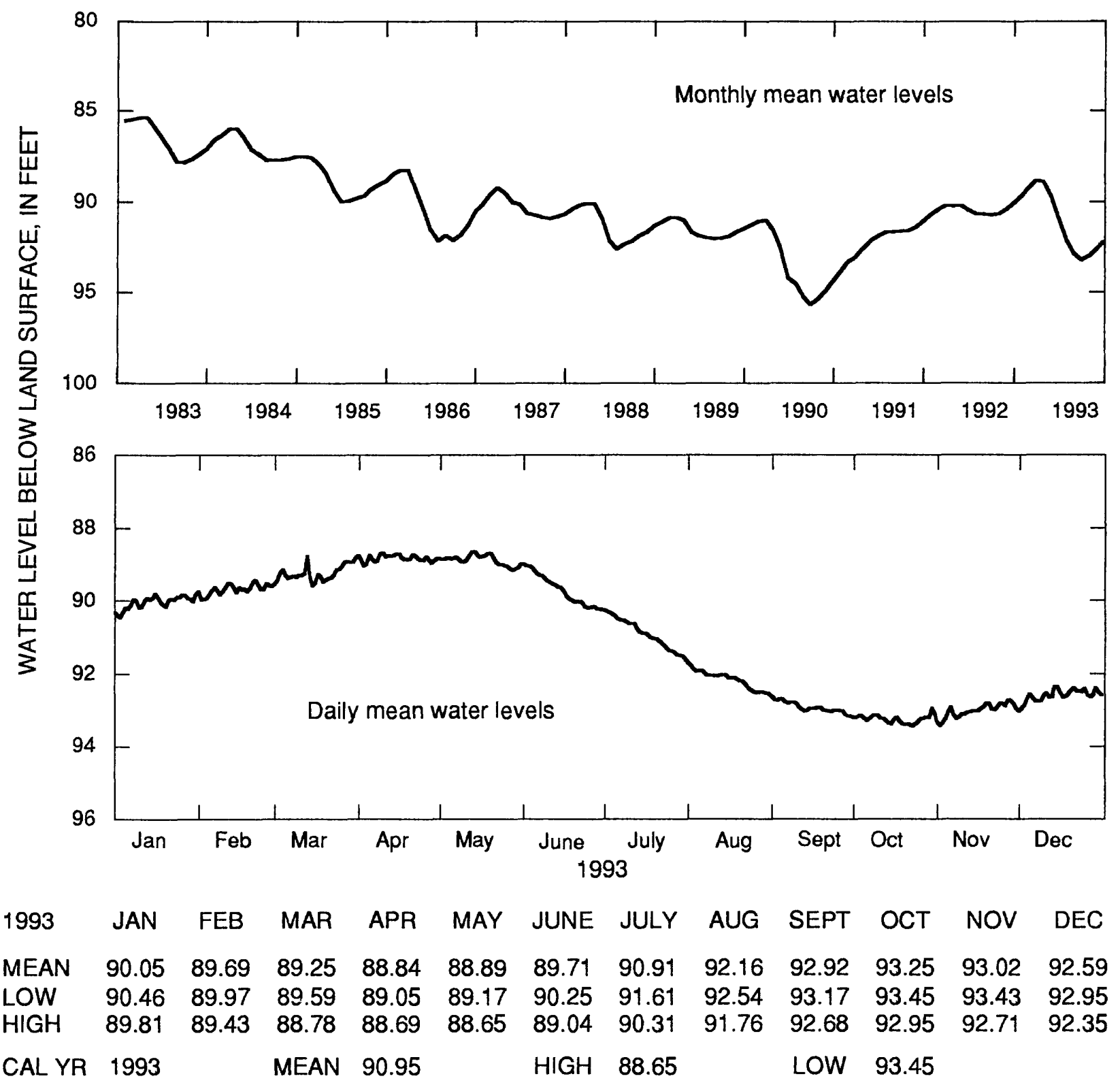

Figure 48.--Water level in observation well 32R002, Bulloch County. 
315214081235301 Local number, 34N089.

LOCATION.--Lat 31 '52'14", long 81'23'53", Hydrologic Unit 03060204.

Owner: U.S. Geological Survey, test well 1.

INSTRUMENTATION.--Analog recorder.

AQUIFER.--Upper Floridan aquifer.

WELL CHARACTERISTICS.--Drilled observation well, diameter 4 in., depth $789 \mathrm{ft}$, cased to $410 \mathrm{ft}$, open hole.

DATUM.--Altitude of land-surface datum is $17 \mathrm{ft}$.

REMARKS.--Well pumped July 11, 1979; water-quality sample collected at conclusion of pumping. Borehole geophysical survey conducted June 15, 1976. Water levels for periods of missing record, April 12-20 and November 11-21, were estimated. PERIOD OF RECORD.--February 1967 to current year.

EXTREMES FOR PERIOD OF RECORD.--Highest water level, $2.34 \mathrm{ft}$ below land-surface datum, March 6, 1967; lowest, $29.43 \mathrm{ft}$ below land-surface datum, October 3, 1990.

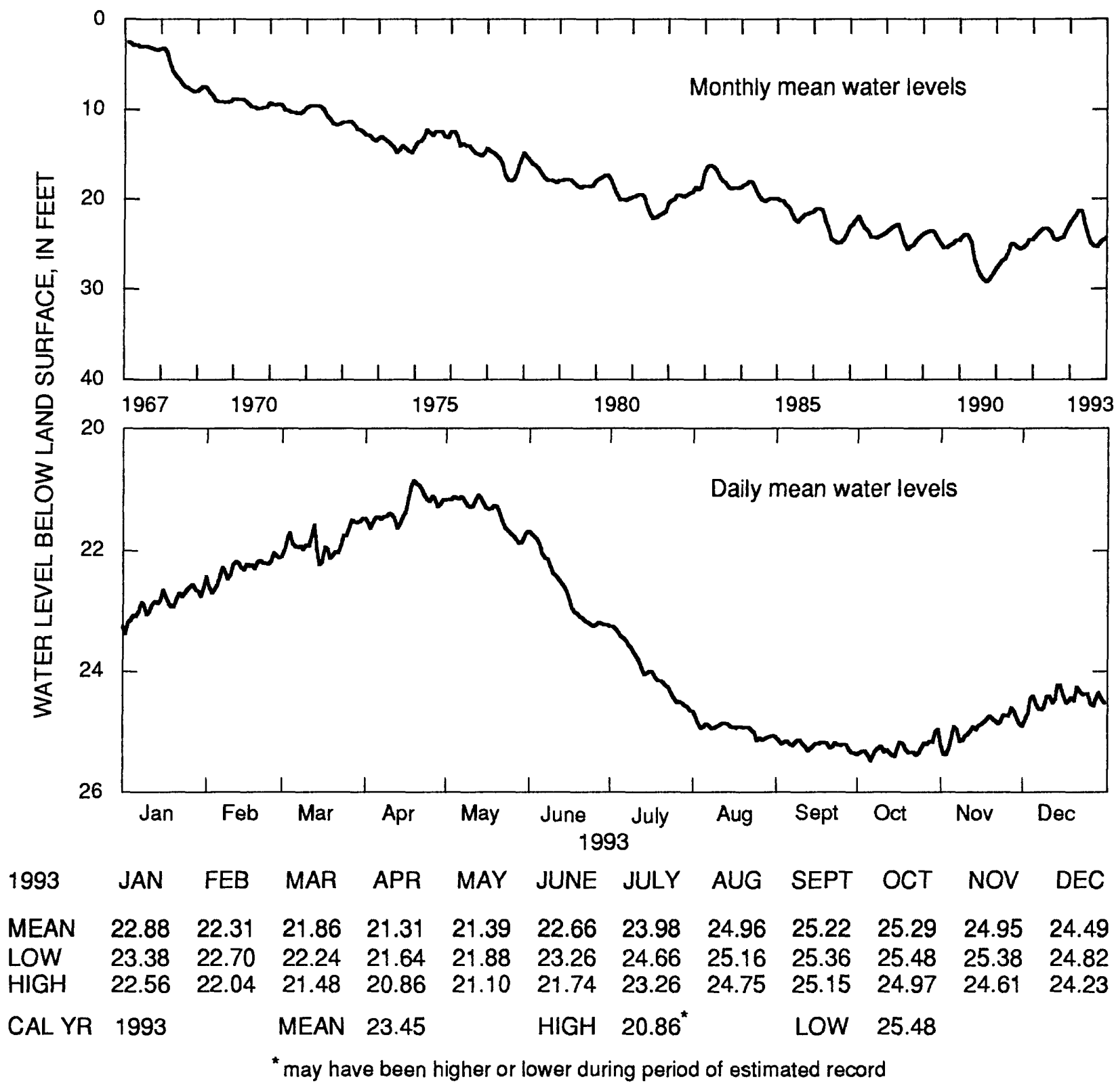

Figure 49.--Water level in observation well 34N089, Liberty County. 
313823081154201 Local number, 35M013.

LOCATION.--Lat 31 $38^{\prime 2} 23^{\prime \prime}$ long 81 '15'42", Hydrologic Unit 03060204.

Owner: U.S. Department of the Interior, Fish and Wildlife Service.

INSTRUMENTATION.--Digital recorder.

AQUIFER.--Upper Floridan aquifer.

WELL CHARACTERISTICS.--Drilled unused supply well, diameter $10 \mathrm{in}$., depth $553 \mathrm{ft}$, cased to $376 \mathrm{ft}$, open hole.

DATUM.--Altitude of land-surface datum is $16.3 \mathrm{ft}$.

REMARKS.--Well pumped August 3, 1976; water-quality sample collected at conclusion of pumping. Borehole geophysical survey conducted June 16, 1976. Water levels for period of missing record, September 9-24, were estimated.

PERIOD OF RECORD.--September 1966 to current year.

EXTREMES FOR PERIOD OF RECORD.--Highest water level, $4.35 \mathrm{ft}$ below land-surface datum, October 4, 1966; lowest, $26.88 \mathrm{ft}$ below land-surface datum, November 14, 1990.

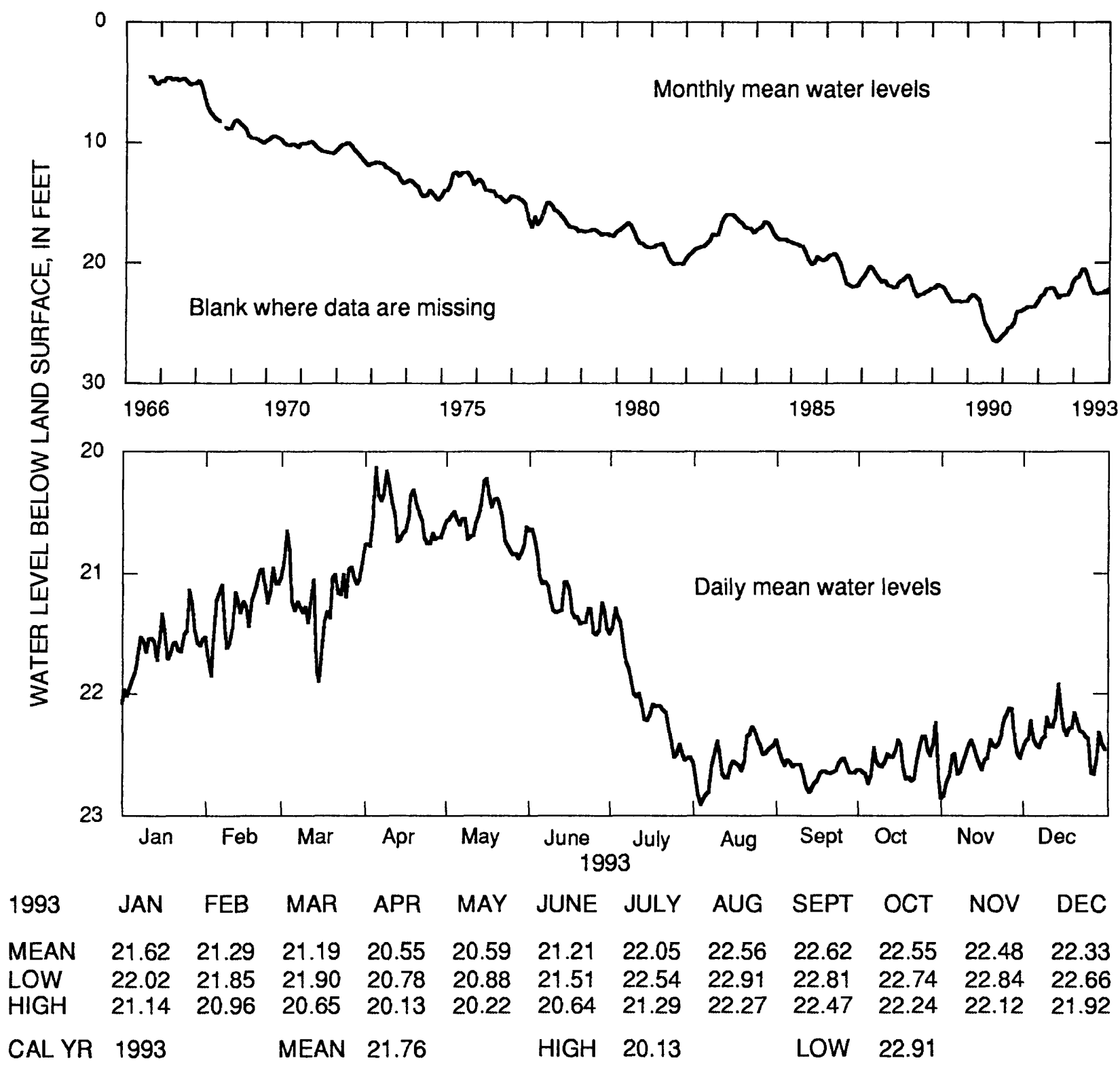

Figure 50.--Water level in observation well 35M013, Mclntosh County. 
The water level in the Upper Floridan aquifer in the Jesup-Doctortown subarea was monitored in three wells in 1993 (fig. 43), each of which is summarized in figures 51-53. In this area, water levels in wells tapping the aquifer are affected mainly by industrial pumping at Doctortown, near Jesup. In 1993, several partial industrial shutdowns, during which the major ground-water user temporarily ceased pumping, is indicated by sharp water-level rises on all three hydrographs. The 1993 mean water levels in the three wells (figs. 51-53) were about $1.0 \mathrm{ft}$ higher than in 1992. 
313701081543501 Local number, 30L003.

LOCATION.--Lat 31 ${ }^{\circ} 37^{\prime} 01^{\prime \prime}$, long 81 ${ }^{\circ} 54^{\prime} 34^{\prime \prime}$, Hydrologic Unit 03070106.

Owner: City of Jesup Housing Authority.

INSTRUMENTATION.--Analog recorder.

AQUIFER.--Upper Floridan aquifer.

WELL CHARACTERISTICS.--Drilled unused supply well, diameter 4 in., depth $584 \mathrm{ft}$, cased to $472 \mathrm{ft}$, open hole.

DATUM.--Altitude of land-surface datum is $107 \mathrm{ft}$.

REMARKS.--Borehole geophysical survey conducted August 19, 1963.

PERIOD OF RECORD.--January 1964 to March 1967; February 1976 to current year.

EXTREMES FOR PERIOD OF RECORD.--Highest water level, $59.98 \mathrm{ft}$ below land-surface datum, April 19, 1964; lowest,

$88.91 \mathrm{ft}$ below land-surface datum, October 7, 1990.

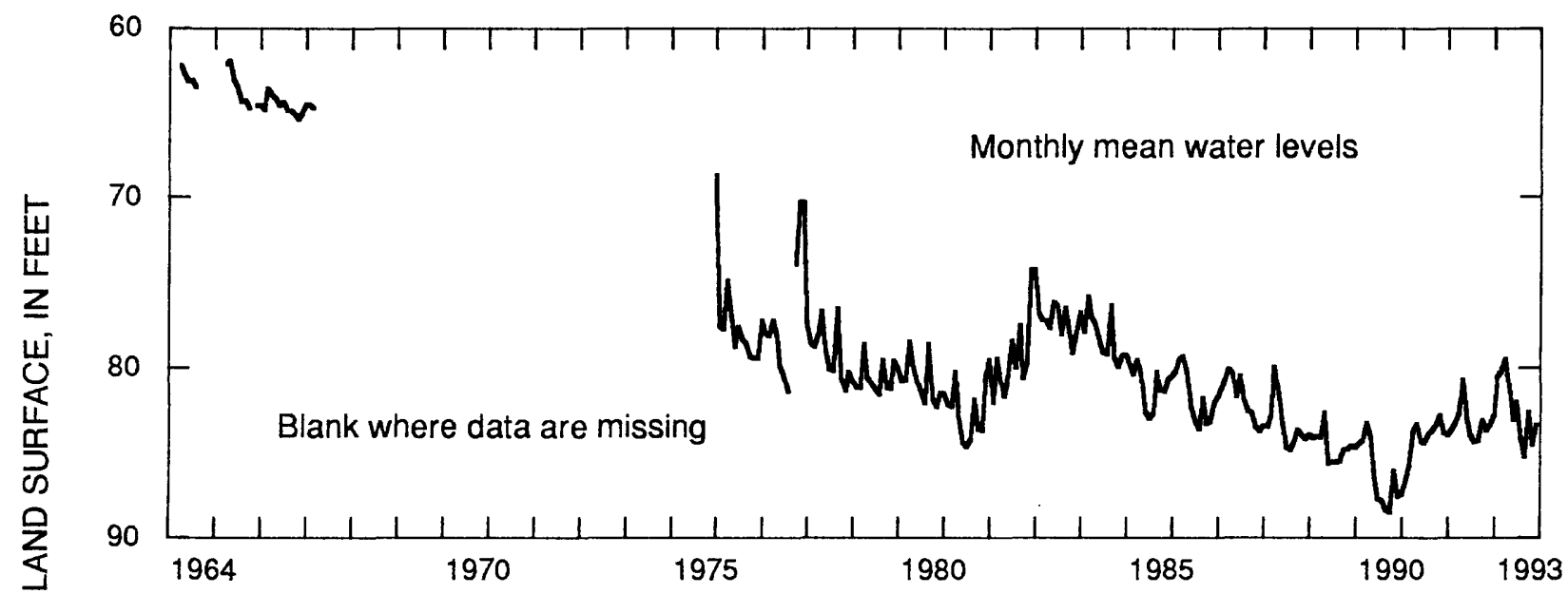

$\begin{array}{lcccccccccccc}1993 & \text { JAN } & \text { FEB } & \text { MAR } & \text { APR } & \text { MAY } & \text { JUNE } & \text { JULY } & \text { AUG } & \text { SEPT } & \text { OCT } & \text { NOV } & \text { DEC } \\ \text { MEAN } & 82.79 & 80.53 & 80.20 & 79.49 & 81.04 & 83.06 & 81.96 & 84.09 & 85.21 & 82.59 & 84.53 & 83.33 \\ \text { LOW } & 83.28 & 81.92 & 81.84 & 81.35 & 82.34 & 83.72 & 84.31 & 84.80 & 85.63 & 85.72 & 85.13 & 84.83 \\ \text { HIGH } & 82.50 & 79.56 & 78.30 & 74.96 & 79.52 & 82.07 & 77.97 & 82.47 & 84.89 & 80.06 & 83.28 & 80.02 \\ \text { CAL YR } & 1993 & & \text { MEAN } & 82.41 & & \text { HIGH } & 74.96 & & \text { LOW } & 85.73 & & \end{array}$

Figure 51.--Water level in observation well 30L003, Wayne County. 
313253081433502 Local number, 32L015.

LOCATION.--Lat 31³2'52", long 81 43'36", Hydrologic Unit 03070106.

Owner: Georgia Geologic Survey, Gardi test well 1.

INSTRUMENTATION.--Digital recorder.

AQUIFER.--Upper Floridan aquifer.

WELL CHARACTERISTICS.--Drilled observation well, diameter 4 in., depth $750 \mathrm{ft}$, cased to $545 \mathrm{ft}$, open hole.

DATUM.--Altitude of land-surface datum is $74 \mathrm{ft}$.

REMARKS.--Borehole geophysical survey conducted April 20, 1983.

PERIOD OF RECORD.--April 1983 to current year.

EXTREMES FOR PERIOD OF RECORD.--Highest water level, $49.12 \mathrm{ft}$ below land-surface datum, March 19, 1984; lowest, $64.05 \mathrm{ft}$ below land-surface datum, October 7-8, 1990.

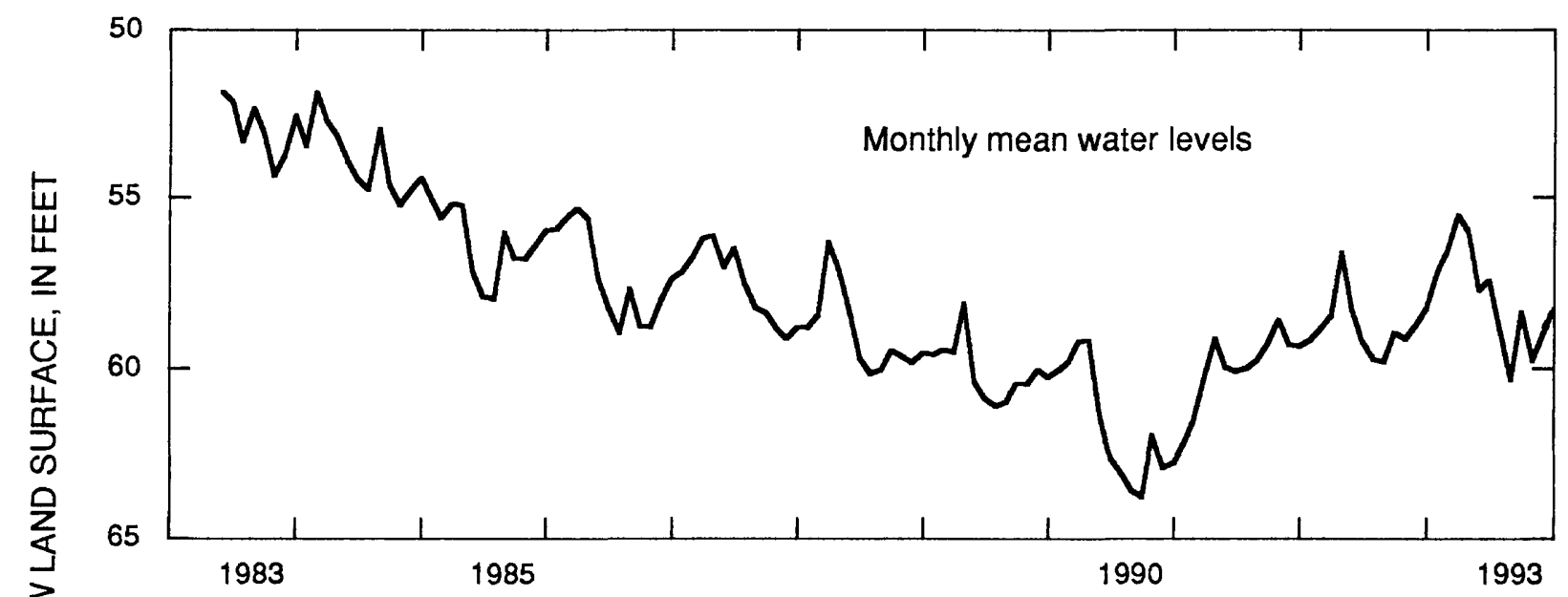

$\begin{array}{lcccccccccccc}1993 & \text { JAN } & \text { FEB } & \text { MAR } & \text { APR } & \text { MAY } & \text { JUNE } & \text { JULY } & \text { AUG } & \text { SEPT } & \text { OCT } & \text { NOV } & \text { DEC } \\ \text { MEAN } & 58.28 & 57.19 & 56.62 & 55.53 & 56.03 & 57.74 & 57.45 & 58.98 & 60.34 & 58.36 & 59.76 & 59.00 \\ \text { LOW } & 58.73 & 57.88 & 57.66 & 56.85 & 56.98 & 58.32 & 58.83 & 59.82 & 60.68 & 60.77 & 60.15 & 59.76 \\ \text { HIGH } & 57.90 & 56.57 & 55.48 & 52.65 & 54.72 & 57.01 & 54.71 & 57.13 & 59.94 & 56.96 & 59.22 & 56.62 \\ \text { CAL YR } & 1993 & & \text { MEAN } & 57.94 & & \text { HIGH } & 52.65 & & \text { LOW } & 60.77 & & \end{array}$

Figure 52.--Water level in observation well 32L015, Wayne County. 
313845081361701 Local number, 33M004.

LOCATION.--Lat 31 $38^{\prime} 54^{\prime \prime}$, long 81 36'04", Hydrologic Unit 03070106.

Owner: U.S. Geological Survey, test well 3.

INSTRUMENTATION.--Digital recorder.

AQUIFER.--Upper Floridan aquifer.

WELL CHARACTERISTICS.--Drilled observation well, diameter 4-3 in., depth $872 \mathrm{ft}$, cased to $538 \mathrm{ft}$, open hole.

DATUM.--Altitude of land-surface datum is $61.2 \mathrm{ft}$ above National Geodetic Vertical Datum of 1929.

REMARKS.--Well pumped and sounded June 17, 1976, to depth of $861 \mathrm{ft}$; water-quality sample collected. Borehole geophysical survey conducted July $28,1976$.

PERIOD OF RECORD.--January 1968 to current year.

EXTREMES FOR PERIOD OF RECORD.--Highest water level, $34.04 \mathrm{ft}$ below land-surface datum, January 14, 1968; lowest, $59.00 \mathrm{ft}$ below land-surface datum, October 8, 1990.

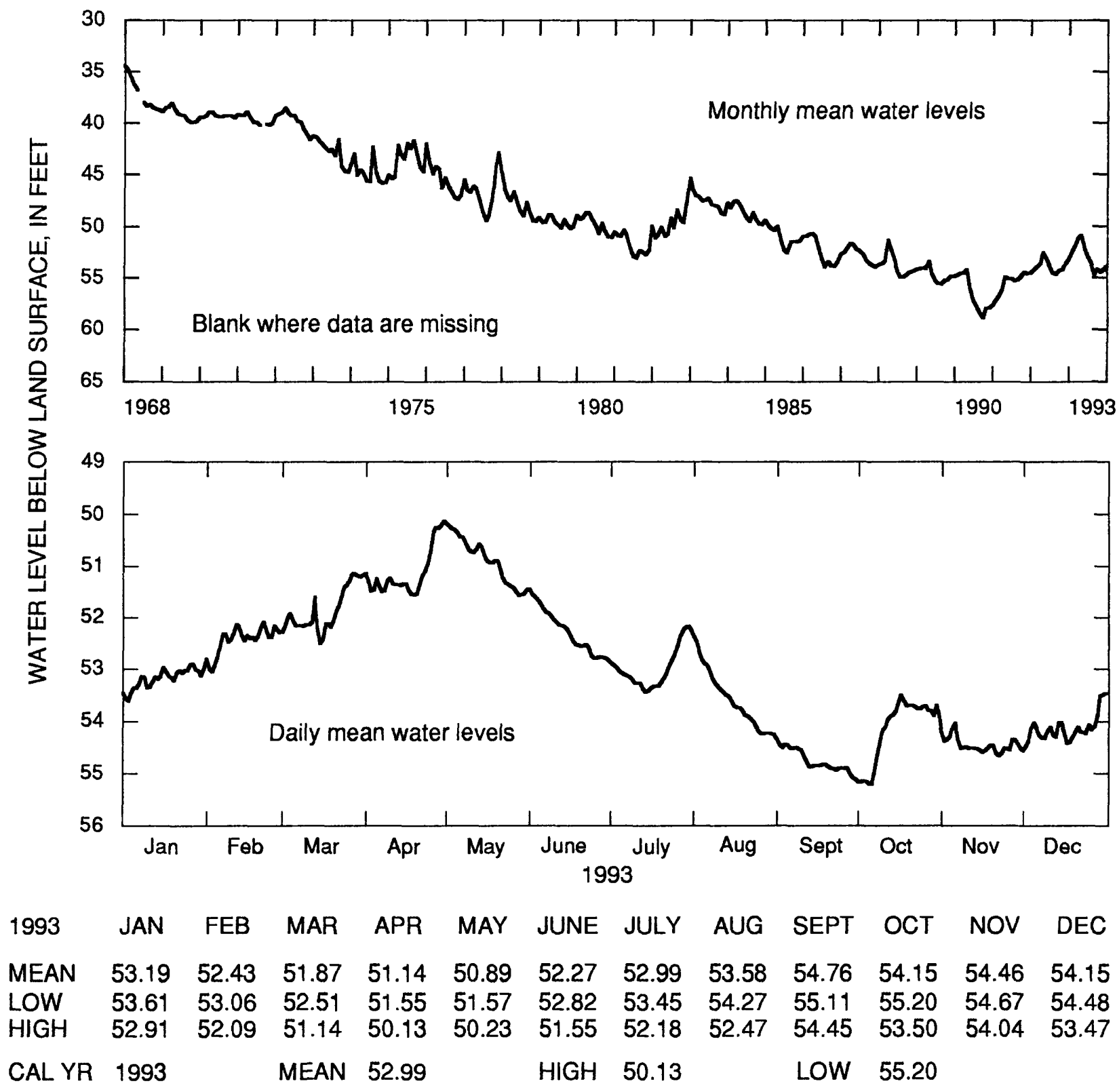

Figure 53.--Water level in observation well 33M004, Long County. 


\section{Brunswick subarea}

The water level in the Upper Floridan aquifer in the Brunswick subarea was monitored in six wells in 1993; data from four of these wells (fig. 43) are summarized in this report. In this subarea, water levels in wells tapping this aquifer primarily are affected by industrial pumping. This pumping has resulted in the development of a cone of depression centered at Brunswick (Peck, 1991). The water-level response to pumping is illustrated in the hydrographs for wells $33 \mathrm{H} 127$ (fig. 54) and 34H403 (fig. 55) tapping the lower water-bearing zone of the Upper Floridan aquifer, and wells 33H133 (fig. 56) and 34H371 (fig. 57) tapping the upper water-bearing zone of the Upper Floridan aquifer. The annual mean water levels in these wells ranged from about the same to about $0.6 \mathrm{ft}$ higher in 1993 than in 1992. 
311007081301701 Local number, $33 \mathrm{H} 127$.

LOCATION.--Lat $31^{\circ} 10^{\prime} 06^{\prime \prime}$ long 81 $30^{\circ} 16^{\prime \prime}$, Hydrologic Unit 03070203.

Owner: U.S. Geological Survey, test well 3.

INSTRUMENTATION.--Analog recorder.

AQUIFER.--Upper Floridan aquifer; lower water-bearing zone.

WELL CHARACTERISTICS.--Drilled observation well, diameter 4 in., depth 1,002 ft, cased to $823 \mathrm{ft}$, open hole.

DATUM.--Altitude of land-surface datum is $6.2 \mathrm{ft}$.

REMARKS.--Well pumped and sampled for analysis of chloride concentration semi-annually. Water levels for periods of missing record, January 1-25 and March 17-23, were estimated.

PERIOD OF RECORD.--August 1962 to current year.

EXTREMES FOR PERIOD OF RECORD.--Highest water level, $14.00 \mathrm{ft}$ above land-surface datum, October 9, 1962; lowest,

$13.22 \mathrm{ft}$ below land-surface datum, July $9,1990$.
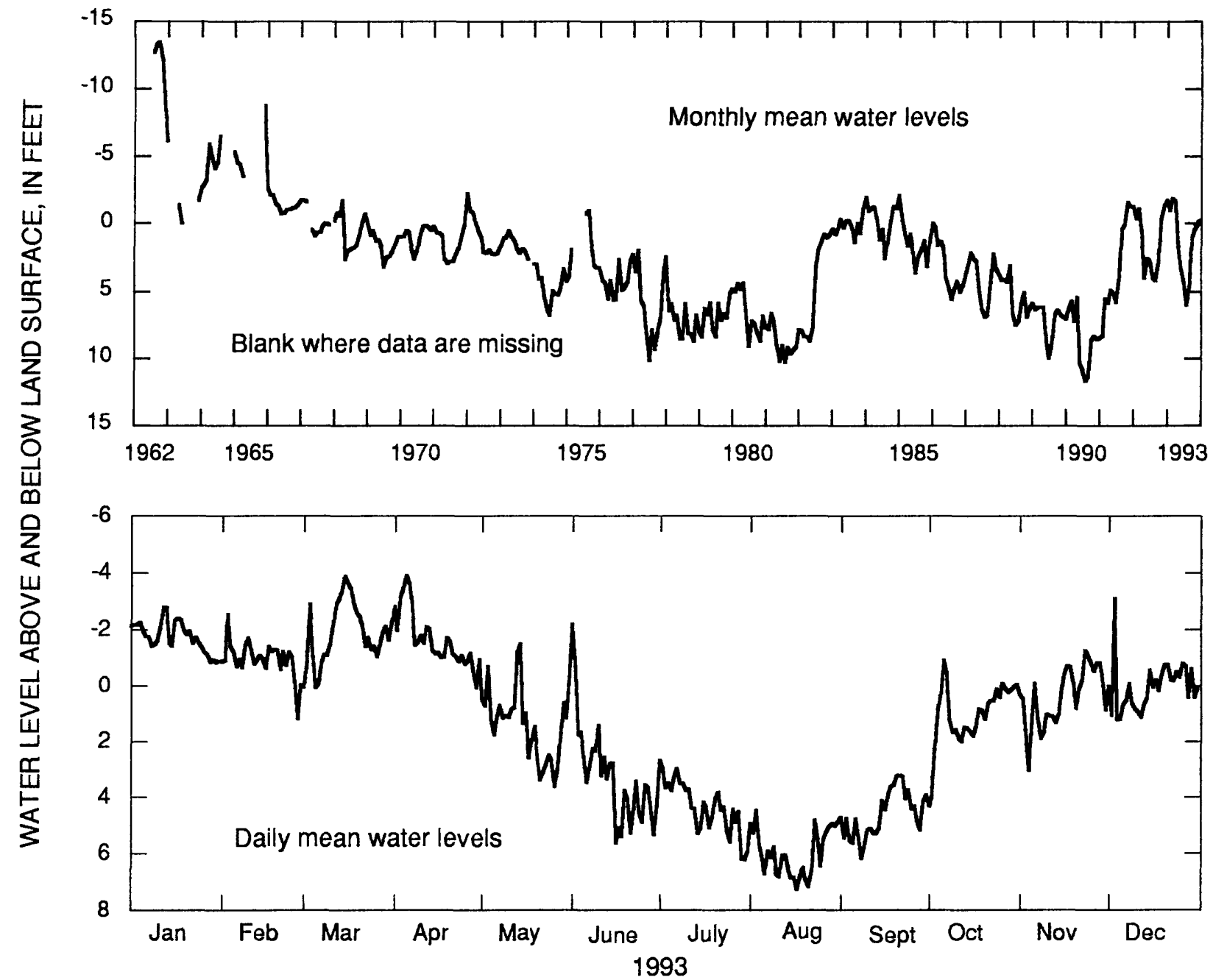

\begin{tabular}{|c|c|c|c|c|c|c|c|c|c|c|c|c|}
\hline 1993 & JAN & FEB & MAR & APR & MAY & JUNE & JULY & AUG & SEPT & OCT & NOV & DEC \\
\hline MEAN & -1.74 & -0.9 & -1.88 & -1.65 & 1.38 & 3.27 & & 5.99 & & & 0.40 & \\
\hline $\begin{array}{l}\text { LOW } \\
\text { HIGH }\end{array}$ & $\begin{array}{l}-0.81 \\
-2.81\end{array}$ & $\begin{array}{r}1.1 \\
-2.5\end{array}$ & $\begin{array}{r}0.07 \\
-3.90\end{array}$ & $\begin{array}{r}0.08 \\
-3.92\end{array}$ & $\begin{array}{r}3.62 \\
-1.50\end{array}$ & $\begin{array}{r}5.62 \\
-0.65\end{array}$ & & & & & $\begin{array}{r}3.03 \\
-1.25\end{array}$ & \\
\hline$A L Y R$ & 1993 & & MEAN & 1.25 & & $\mathrm{HIGH}$ & -3.92 & & LOW & 7.27 & & \\
\hline
\end{tabular}

[Negative value indicates water level above land surface]

Figure 54.--Water level in observation well 33H127, Glynn County. 
310822081294201 Local number, $34 \mathrm{H} 403$.

LOCATION.--Lat $31^{\circ} 08^{\prime 2} 22^{\prime \prime}$ long $81^{\circ} 29^{\prime} 42^{\prime \prime}$, Hydrologic Unit 03070203.

Owner: U.S. Geological Survey, test well 24.

INSTRUMENTATION.--Digital recorder.

AQUIFER.--Upper Floridan aquifer; lower water-bearing zone.

WELL CHARACTERISTICS.--Drilled observation well, diameter 4 in., depth $982 \mathrm{ft}$, cased to $788 \mathrm{ft}$, open hole.

DATUM.--Altitude of land-surface datum is $9.6 \mathrm{ft}$.

REMARKS.--Well pumped and sampled for analysis of chloride concentration semi-annually. Borehole geophysical survey conducted September 9, 1970. Water levels for period of missing record, February 13 to March 11, were estimated.

PERIOD OF RECORD.--August 1974 to current year.

EXTREMES FOR PERIOD OF RECORD.--Highest water level, $12.79 \mathrm{ft}$ above land-surface datum, December 29, 1985; lowest, $4.76 \mathrm{ft}$ below land-surface datum, September $14,1990$.

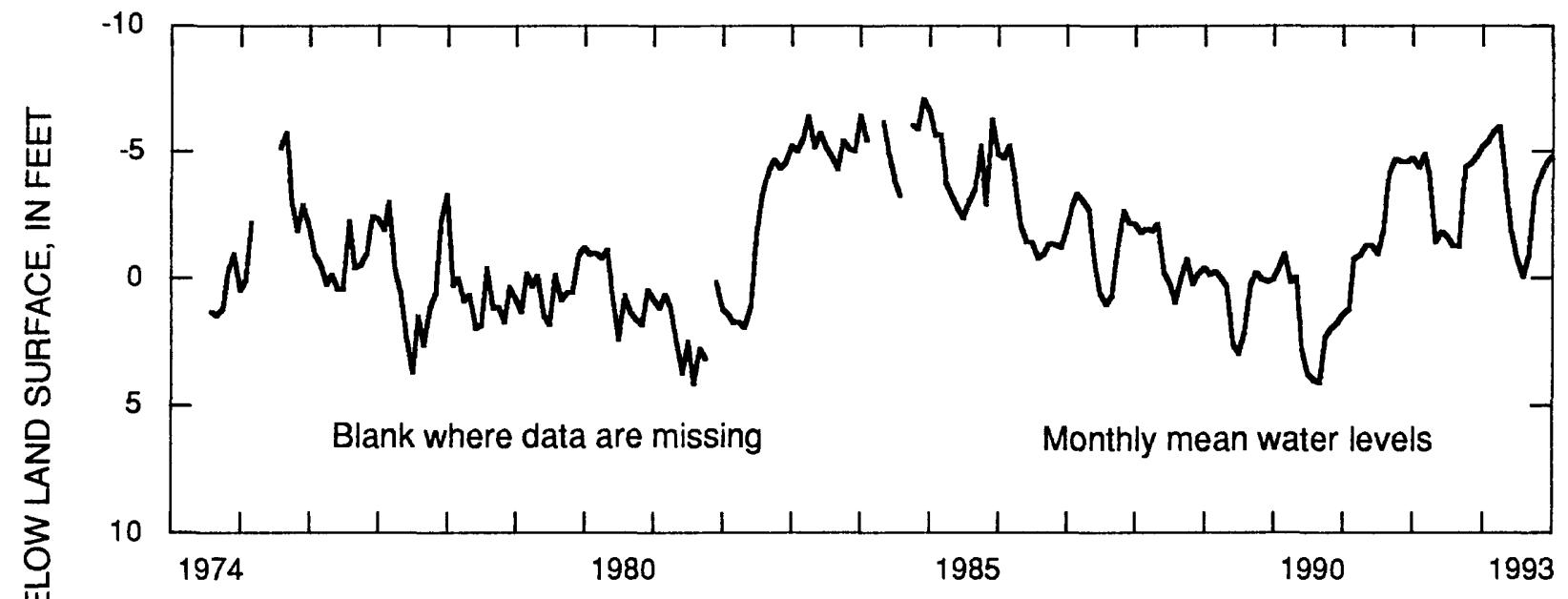

1993

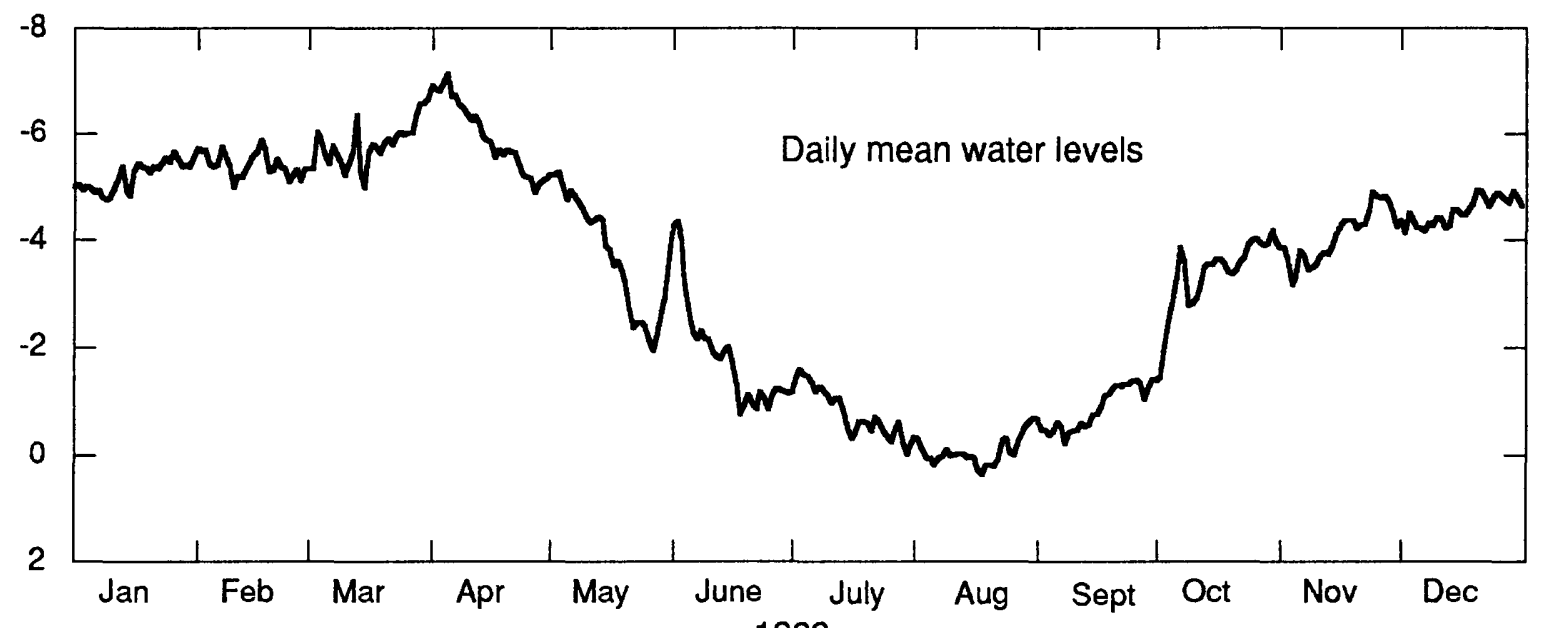

1993

$\begin{array}{rrrrrrrrrrrrr}1993 & \text { JAN } & \text { FEB } & \text { MAR } & \text { APR } & \text { MAY } & \text { JUNE } & \text { JULY } & \text { AUG } & \text { SEPT } & \text { OCT } & \text { NOV } & \text { DEC } \\ \text { MEAN } & -5.19 & -5.41 & -5.79 & -5.96 & -3.73 & -1.85 & -0.79 & -0.06 & -0.85 & -3.33 & -4.08 & -4.53 \\ \text { LOW } & -4.73 & -4.97 & -4.97 & -4.88 & -1.93 & -0.75 & -0.01 & 0.38 & -0.21 & -1.45 & -3.16 & -4.13 \\ \text { HIGH } & -5.65 & -5.87 & -6.67 & -7.15 & -5.26 & -4.34 & -1.60 & -0.69 & -1.41 & -4.17 & -4.89 & -4.92 \\ \text { CAL YR } & 1993 & & \text { MEAN } & -3.45 & & \text { HIGH } & -7.15 & & \text { LOW } & 0.38 & & \end{array}$

[Negative value indicates water level above land surface]

Figure 55.--Water level in observation well 34H403, Glynn County. 
311007081301702 Local number, $33 \mathrm{H} 133$.

LOCATION.--Lat $31^{\circ} 10^{\prime} 08^{\prime \prime}$ long 81 $30^{\prime} 16^{\prime \prime}$, Hydrologic Unit 03070203.

Owner: U.S. Geological Survey, test well 6.

INSTRUMENTATION.--Digital recorder.

AQUIFER.--Upper Floridan aquifer; upper water-bearing zone.

WELL CHARACTERISTICS.--Drilled observation well, diameter 4 in., depth $790 \mathrm{ft}$, cased to $520 \mathrm{ft}$, open hole.

DATUM.--Altitude of land-surface datum is $6.7 \mathrm{ft}$.

REMARKS.--Well pumped and sampled for analysis of chloride concentration semi-annually. Borehole geophysical survey conducted September 26, 1977.

PERIOD OF RECORD.--January 1963 to current year.

EXTREMES FOR PERIOD OF RECORD.--Highest water level, $9.07 \mathrm{ft}$ above land-surface datum, December 26, 1965; lowest, $21.87 \mathrm{ft}$ below land-surface datum, July $22,1977$.
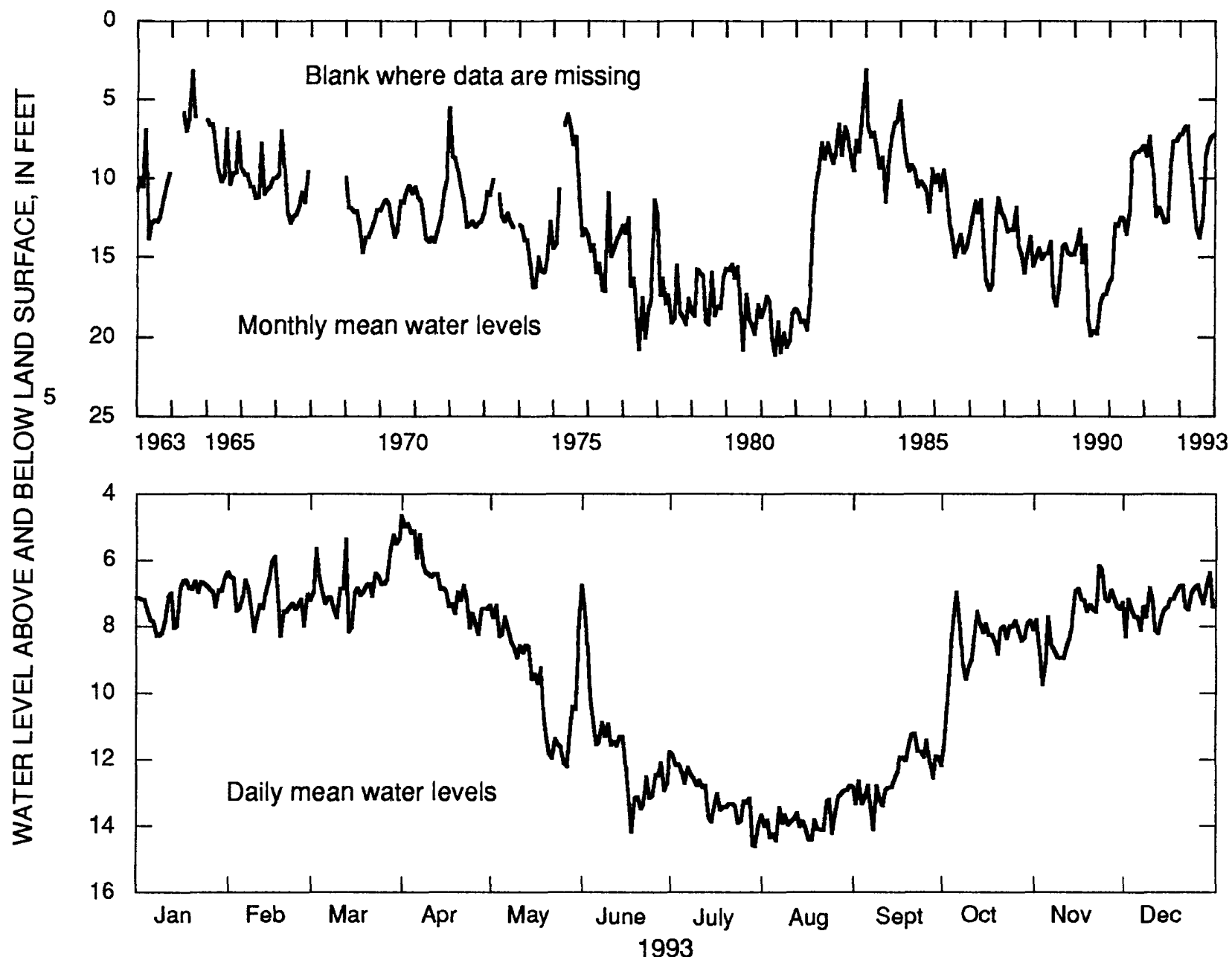

$\begin{array}{rrrrrrrrrrrrr}1993 & \text { JAN } & \text { FEB } & \text { MAR } & \text { APR } & \text { MAY } & \text { JUNE } & \text { JULY } & \text { AUG } & \text { SEPT } & \text { OCT } & \text { NOV } & \text { DEC } \\ \text { MEAN } & 7.23 & 7.17 & 6.73 & 6.66 & 9.61 & 11.72 & 13.12 & 13.78 & 12.46 & 8.53 & 7.82 & 7.34 \\ \text { LOW } & 8.29 & 8.28 & 8.18 & 8.25 & 12.23 & 14.19 & 14.61 & 14.45 & 14.10 & 11.45 & 9.74 & 8.31 \\ \text { HIGH } & 6.54 & 5.89 & 5.25 & 4.88 & 7.38 & 7.49 & 11.86 & 12.78 & 11.22 & 6.98 & 6.18 & 6.39 \\ \text { AL YR } & 1993 & & \text { MEAN } & 9.36 & & \text { HIGH } & 4.64 & & \text { LOW } & 14.61 & & \end{array}$

Figure 56.--Water level in observation well $33 \mathrm{H} 133$, Glynn County. 
310818081293701 Local number, $34 \mathrm{H} 371$.

LOCATION.--Lat $31^{\circ} 08^{\prime} 18^{\prime \prime}$, long 81 ${ }^{\circ} 30^{\prime} 16^{\prime \prime}$, Hydrologic Unit 03070203.

Owner: U.S. Geological Survey, test well 11.

INSTRUMENTATION.--Digital recorder.

AQUIFER.--Upper Floridan aquifer; upper water-bearing zone.

WELL CHARACTERISTICS.--Drilled observation well, diameter 3-2 in., depth $719 \mathrm{ft}$, cased to $512 \mathrm{ft}$, open hole.

DATUM.--Altitude of land-surface datum is $9.8 \mathrm{ft}$.

REMARKS.--Well pumped and sampled for analysis of chloride concentration semi-annually. Borehole geophysical survey conducted October 6, 1966. Water levels for periods of missing record, January 16-25, June 17-30, July 1-28, were estimated. PERIOD OF RECORD.--January 1967 to current year.

EXTREMES FOR PERIOD OF RECORD.--Highest water level, $9.95 \mathrm{ft}$ above land-surface datum, March 18-19, 1967; lowest, $5.64 \mathrm{ft}$ below land-surface datum, September 14, 1990.

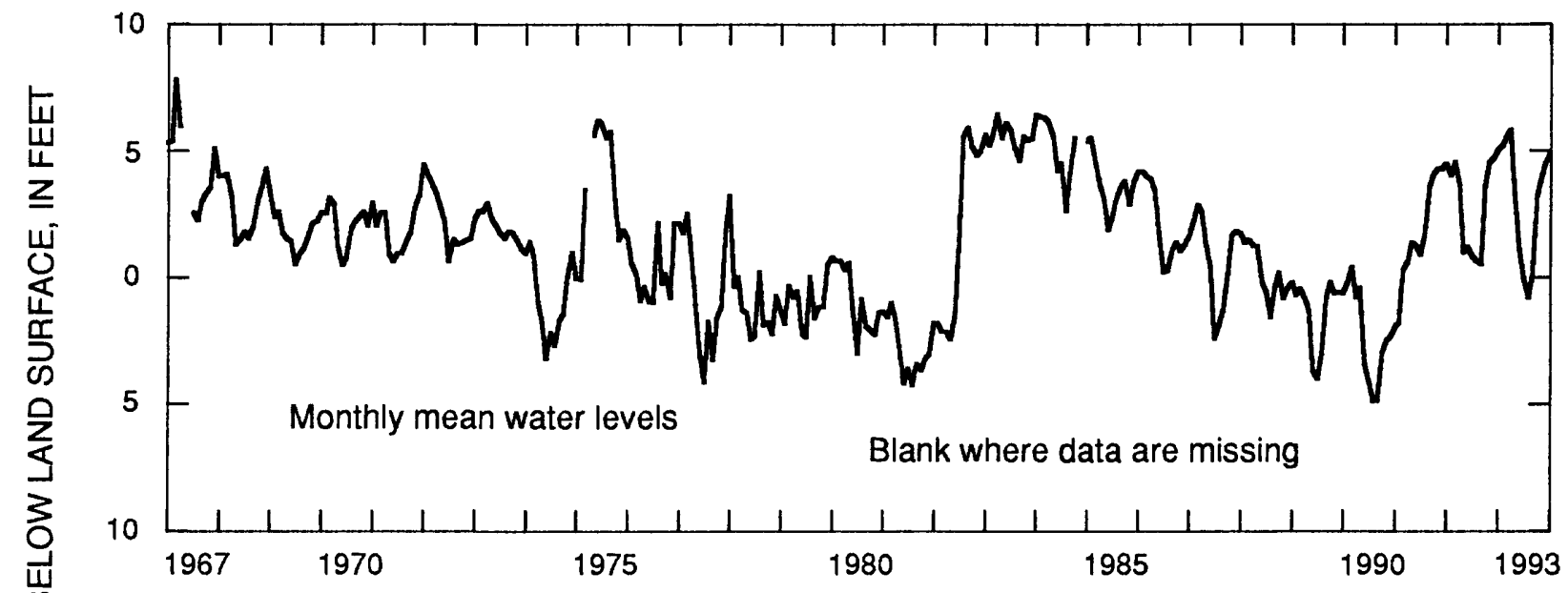

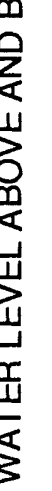

5

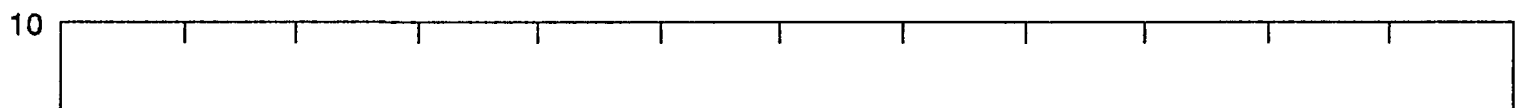

Daily mean water levels

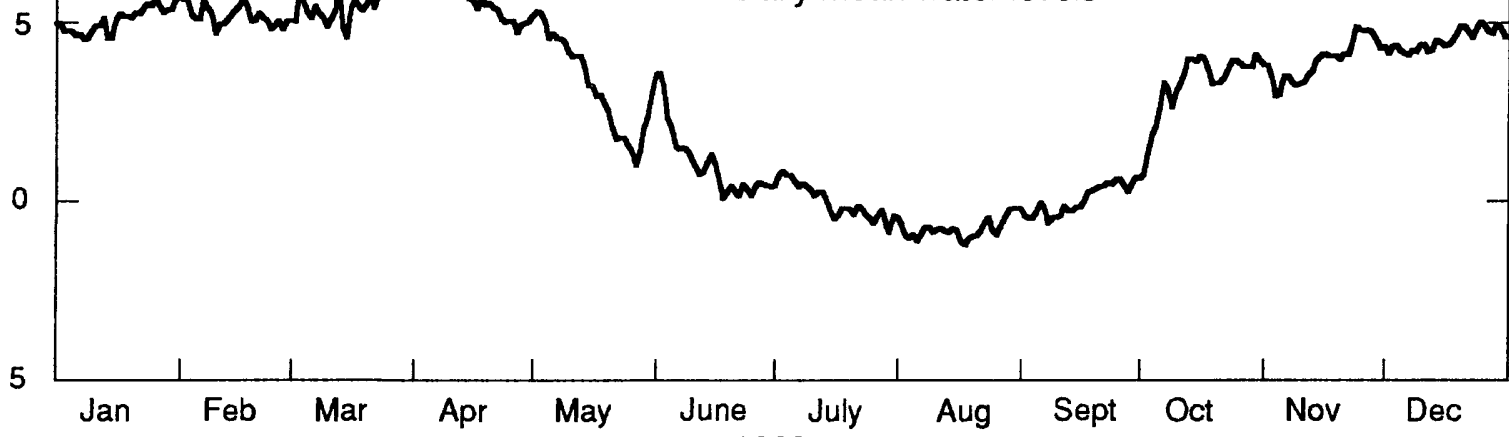

FEB

MAR

\section{APR}

MEAN -5.04

LOW -4.50

$-5.19$

$-4.69$

$-5.56$

$-4.58$

$-5.81$

MAY JUNE JULY

AUG SEPT

OCT

NOV

DEC

$\mathrm{HIGH} \quad-5.65$

$-5.63$

$-6.78$

$-4.72$

$-3.26$

$-1.08$

0.02

0.79

$-0.02$

$-3.21$

$-3.92$

$-4.50$

CAL YR 1993

MEAN -3.05

$-1.01$

$-0.06$

0.88

1.24

0.64

$-0.74$

$-2.91$

$-4.09$

[Negative value indicates water level above land surface]

$\mathrm{HIGH} \quad-7.11$

Low

$-4.10$

$-4.88$

$-5.02$

Figure 57.--Water level in observation well 34H371, Glynn County. 
The water level in the Upper Floridan aquifer in the St Marys-Okefenokee Swamp subarea (fig. 43) is monitored in two wells, which are summarized in figures 58-59. Water levels in wells tapping the aquifer in this subarea are affected by industrial pumping. The 1993 mean water levels in well 33E027 (fig. 58) at Kings Bay and well 27E004 (fig. 59) in western Charlton County were from about the same to $0.3 \mathrm{ft}$ higher than in 1992. 
304756081311101 Local number, 33E027.

LOCATION.--Lat 30 47'56", long 81 $31^{\prime} 11^{\prime \prime}$, Hydrologic Unit 03070203.

Owner: U.S. Department of the Navy, Kings Bay test well 1.

INSTRUMENTATION.--Electronic data recorder.

AQUIFER.--Upper Floridan aquifer.

WELL CHARACTERISTICS.--Drilled test well, diameter 8 in., depth 1,306 ft, cased to $555 \mathrm{ft}$, backfilled to $990 \mathrm{ft}$, open hole.

DATUM.--Altitude of land-surface datum is $10.0 \mathrm{ft}$.

REMARKS.--Borehole geophysical survey conducted February 9, 1979. Water levels for period of missing record, September 8-24, were estimated.

PERIOD OF RECORD.--August 1979 to current year.

EXTREMES FOR PERIOD OF RECORD.--Highest water level, $24.71 \mathrm{ft}$ above land-surface datum, March 28, 1984, and March

17, 1983; lowest, $13.90 \mathrm{ft}$ above land-surface datum, June 10-11, 1985.

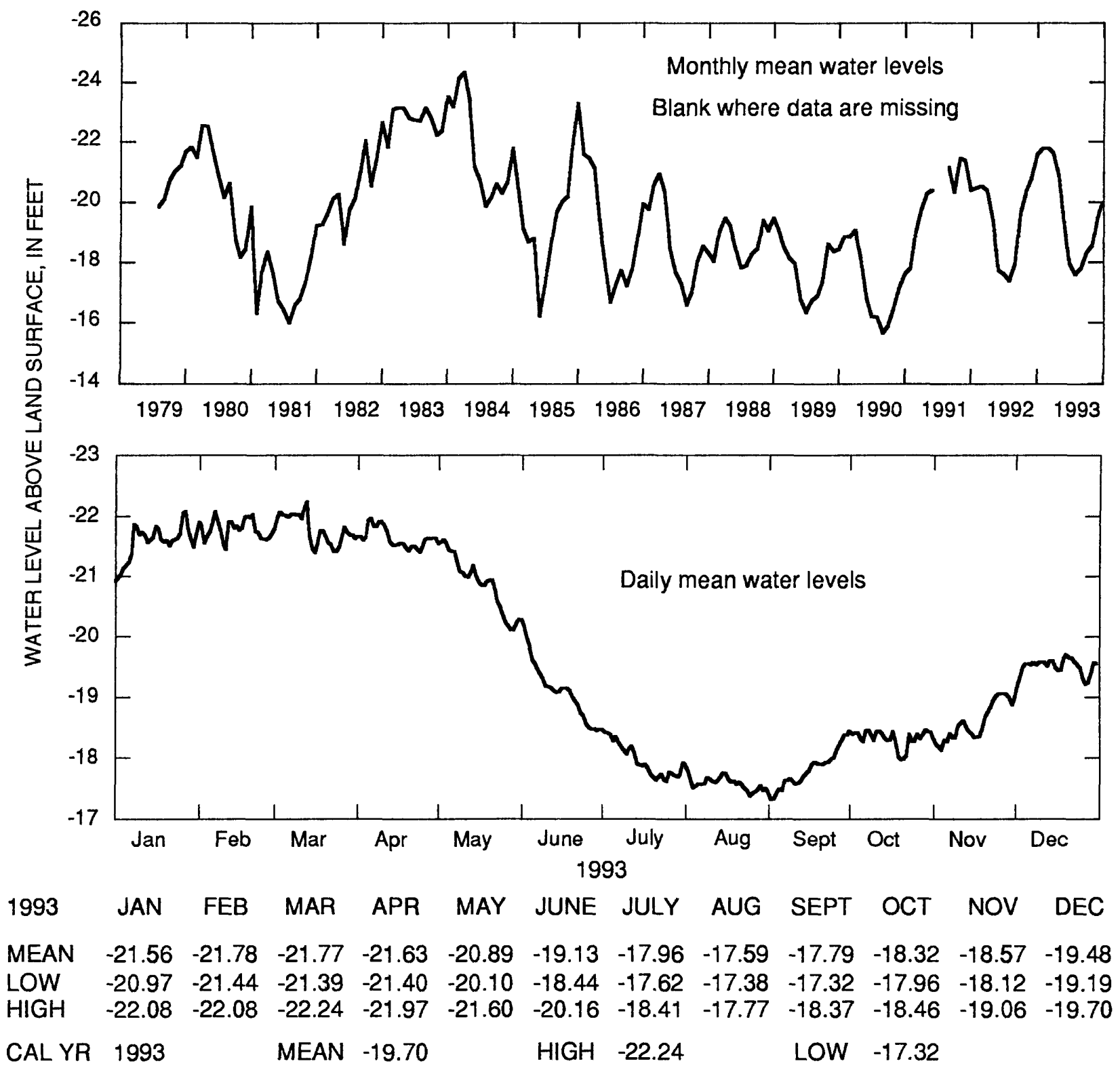

[Negative value indicates water level above land surface]

Figure 58.--Water level in observation well 33E027, Camden County. 
304942082213801 Local number, 27 E004.

LOCATION.--Lat $30^{\circ} 49^{\prime} 43^{\prime \prime}$, long $82^{\circ} 2138^{\prime \prime}$, Hydrologic Unit 03110201.

Owner: U.S. Geological Survey, test well OK-9.

INSTRUMENTATION.--Digital recorder.

AQUIFER.--Upper Floridan aquifer.

WELL CHARACTERISTICS.--Drilled observation well, diameter 4 in., depth $700 \mathrm{ft}$, cased to $498 \mathrm{ft}$, open hole.

DATUM.--Altitude of land-surface datum is $116 \mathrm{ft}$.

REMARKS.--Well drilled in May 1978 to replace USGS test well OK-8 (27E002).

PERIOD OF RECORD.--June 14, 1978 to January 26, 1979; January 1, 1980 to current year.

EXTREMES FOR PERIOD OF RECORD.--Highest water level, $62.30 \mathrm{ft}$ below land-surface datum, May 9, 1984; lowest, $73.91 \mathrm{ft}$ below land-surface datum, October 7-8, 1990.

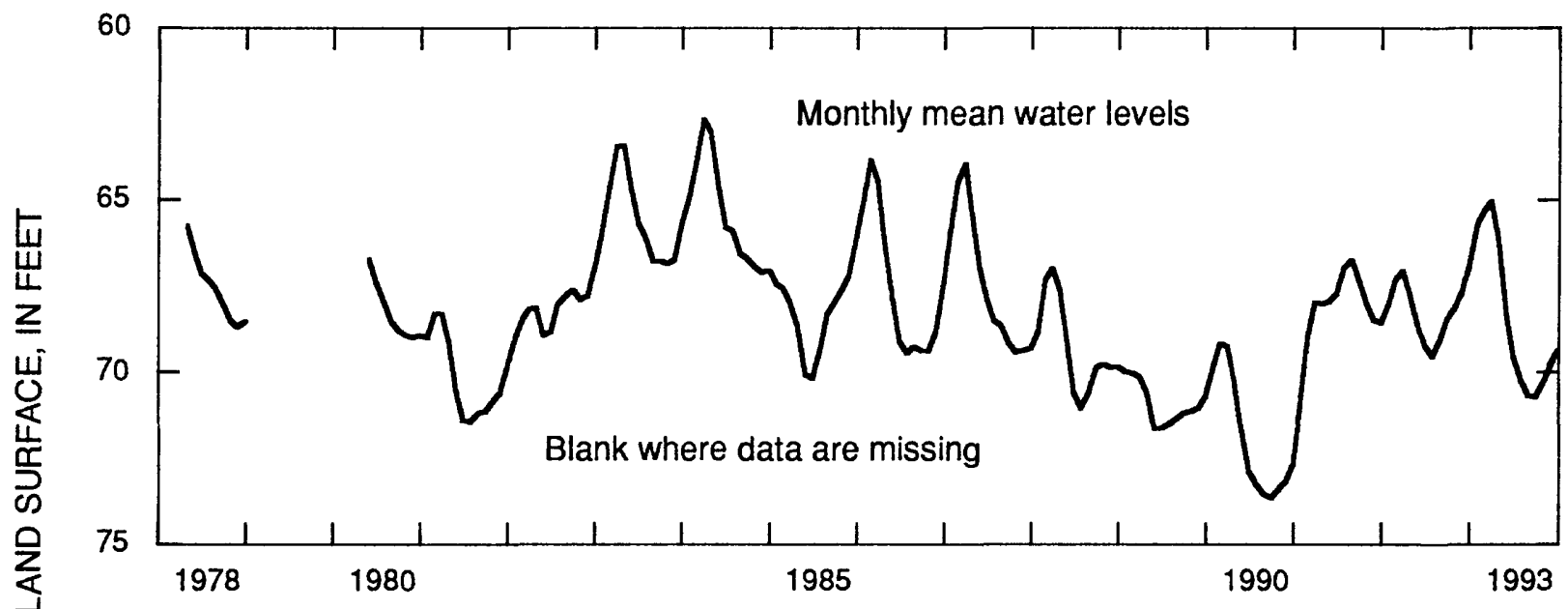

$\begin{array}{lcccccccccccc}1993 & \text { JAN } & \text { FEB } & \text { MAR } & \text { APR } & \text { MAY } & \text { JUNE } & \text { JULY } & \text { AUG } & \text { SEPT } & \text { OCT } & \text { NOV } & \text { DEC } \\ \text { MEAN } & 66.97 & 65.74 & 65.36 & 65.04 & 66.14 & 68.34 & 69.58 & 70.23 & 70.67 & 70.73 & 70.34 & 69.87 \\ \text { LOW } & 67.52 & 66.19 & 65.73 & 65.34 & 67.14 & 69.20 & 69.89 & 70.53 & 70.83 & 70.88 & 70.81 & 70.21 \\ \text { HIGH } & 66.26 & 65.42 & 64.93 & 64.86 & 65.35 & 67.24 & 69.25 & 69.90 & 70.56 & 70.35 & 70.00 & 69.60 \\ \text { CAL YR } & 1993 & & \text { MEAN } & 68.27 & & \text { HIGH } & 64.86 & & \text { LOW } & 70.88 & & \end{array}$

Figure 59.--Water level in observation well 27E004, Charlton County. 


\section{Lower Floridan aquifer}

Brunswick area

The water level in the Lower Floridan aquifer was monitored in five wells in the Brunswick area in 1993; data from two of these wells (fig. 60), are summarized in figures 61-62. Water levels in wells tapping the Lower Floridan aquifer in this area are mainly influenced by withdrawal from the Upper Floridan aquifer. The hydrographs of these wells are similar to those of the Upper Floridan aquifer (figs. 54-57). The 1993 mean water level in wells $34 \mathrm{H} 391$ and $33 \mathrm{~J} 044$ ranged from about 0.2 to $0.5 \mathrm{ft}$ higher than in 1992. 


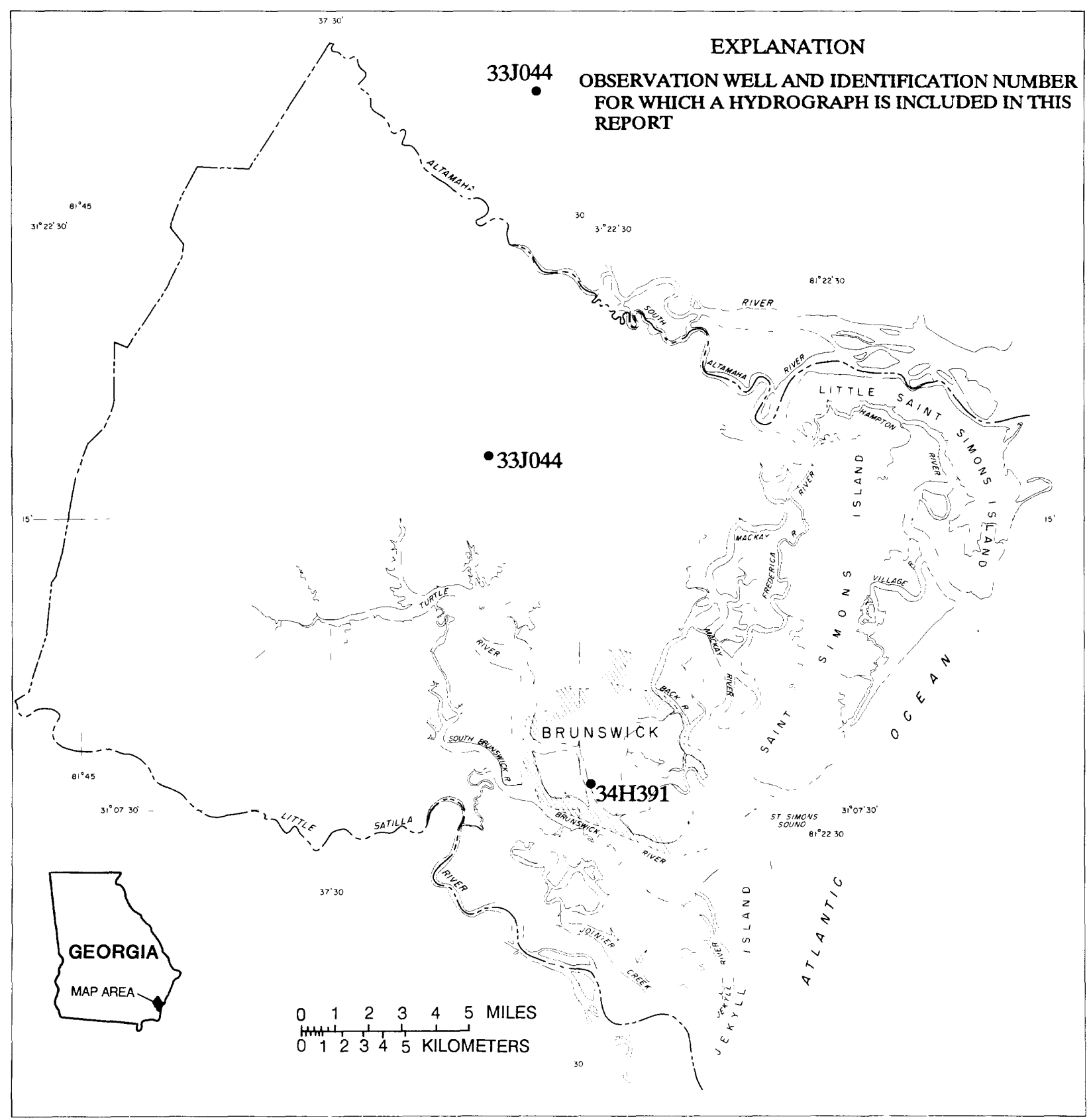

Figure 60.--Locations of observation wells completed in the Lower Floridan aquifer. 
310818081294201 Local number, $34 \mathrm{H} 391$.

LOCATION.--Lat $31^{\circ} 08^{\prime} 18^{\prime \prime}$, long 81 $29^{\prime} 42^{\prime \prime}$, Hydrologic Unit 03070203.

Owner: U.S. Geological Survey, test well 16.

INSTRUMENTATION.--Digital recorder.

AQUIFER.--Lower Floridan aquifer.

WELL CHARACTERISTICS.--Drilled observation well, diameter 6 in., depth 1,150 ft, cased to $1,070 \mathrm{ft}$, open hole.

DATUM.--Altitude of land-surface datum is $7.13 \mathrm{ft}$.

REMARKS.--Well pumped and sampled for analysis of chloride concentration semi-annually.

PERIOD OF RECORD.--August 1975 to current year.

EXTREMES FOR PERIOD OF RECORD.--Highest water level, $11.65 \mathrm{ft}$ above land-surface datum, October 13-14, 1985;

lowest, $2.96 \mathrm{ft}$ below land-surface datum, July 27, 1977.

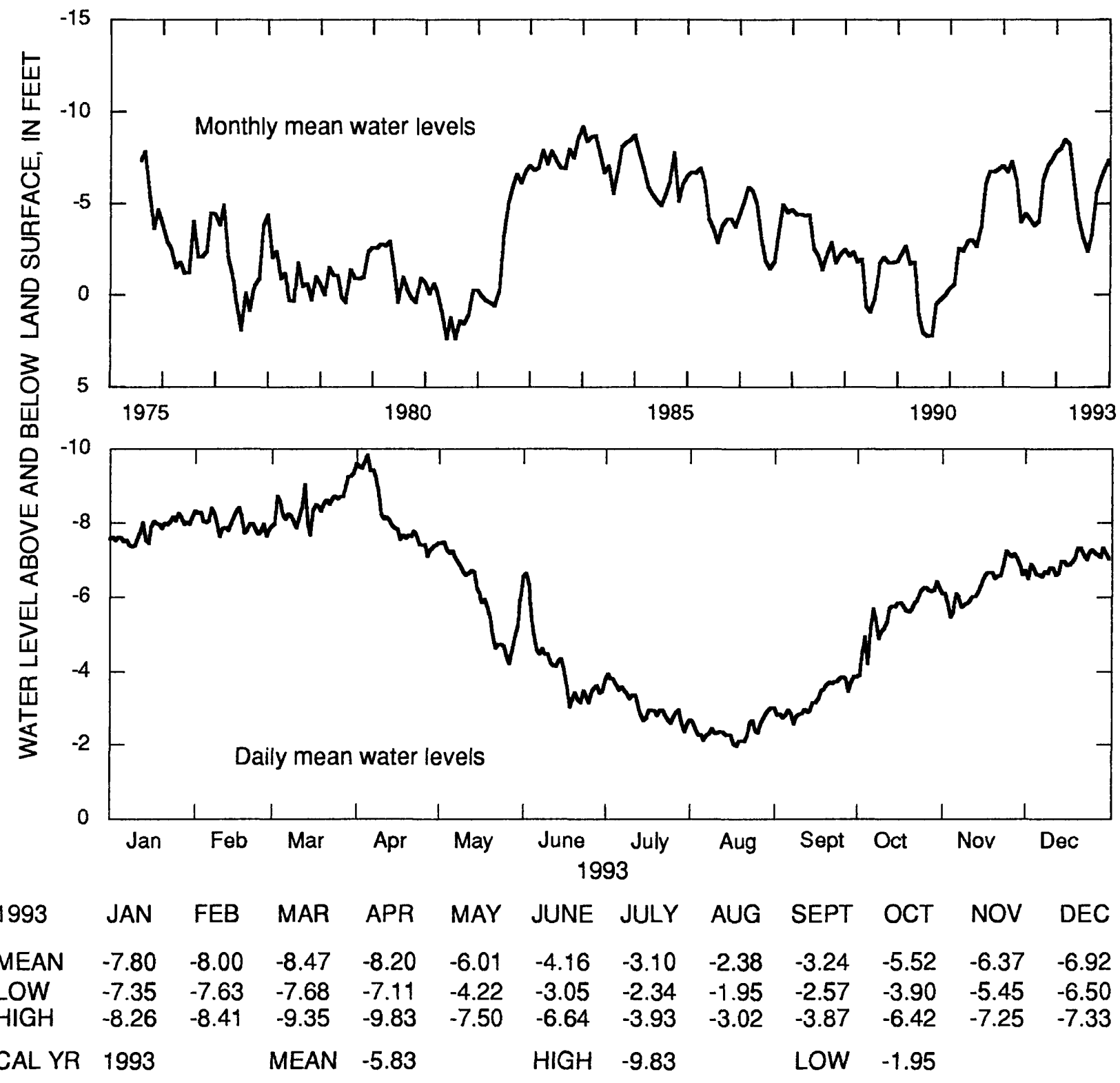

[Negative value indicates water level above land surface]

Figure 61.--Water level in observation well 34H391, Glynn County. 
311633081324001 Local number, 33J044.

LOCATION.--Lat 31 '16'33", long 81 '32'40", Hydrologic Unit 03070203.

Owner: Georgia Pacific Co., USGS test well 27.

INSTRUMENTATION.--Digital recorder.

AQUIFER.--Lower Floridan aquifer.

WELL CHARACTERISTICS.--Drilled unused oil-test well converted to observation well, diameter 9 in., depth 2,260

$\mathrm{ft}$, cased to $1,079 \mathrm{ft}$, open hole.

DATUM.--Altitude of land-surface datum is $20 \mathrm{ft}$.

REMARKS.--This is the Sterling oil-test well. Water levels for period, November 5-23, were estimated.

PERIOD OF RECORD.--May 1979 to current year.

EXTREMES FOR PERIOD OF RECORD.--Highest water level, $3.09 \mathrm{ft}$ above land-surface datum, October 13, 1985; lowest,

$8.44 \mathrm{ft}$ below land-surface datum, September 19, 1990.
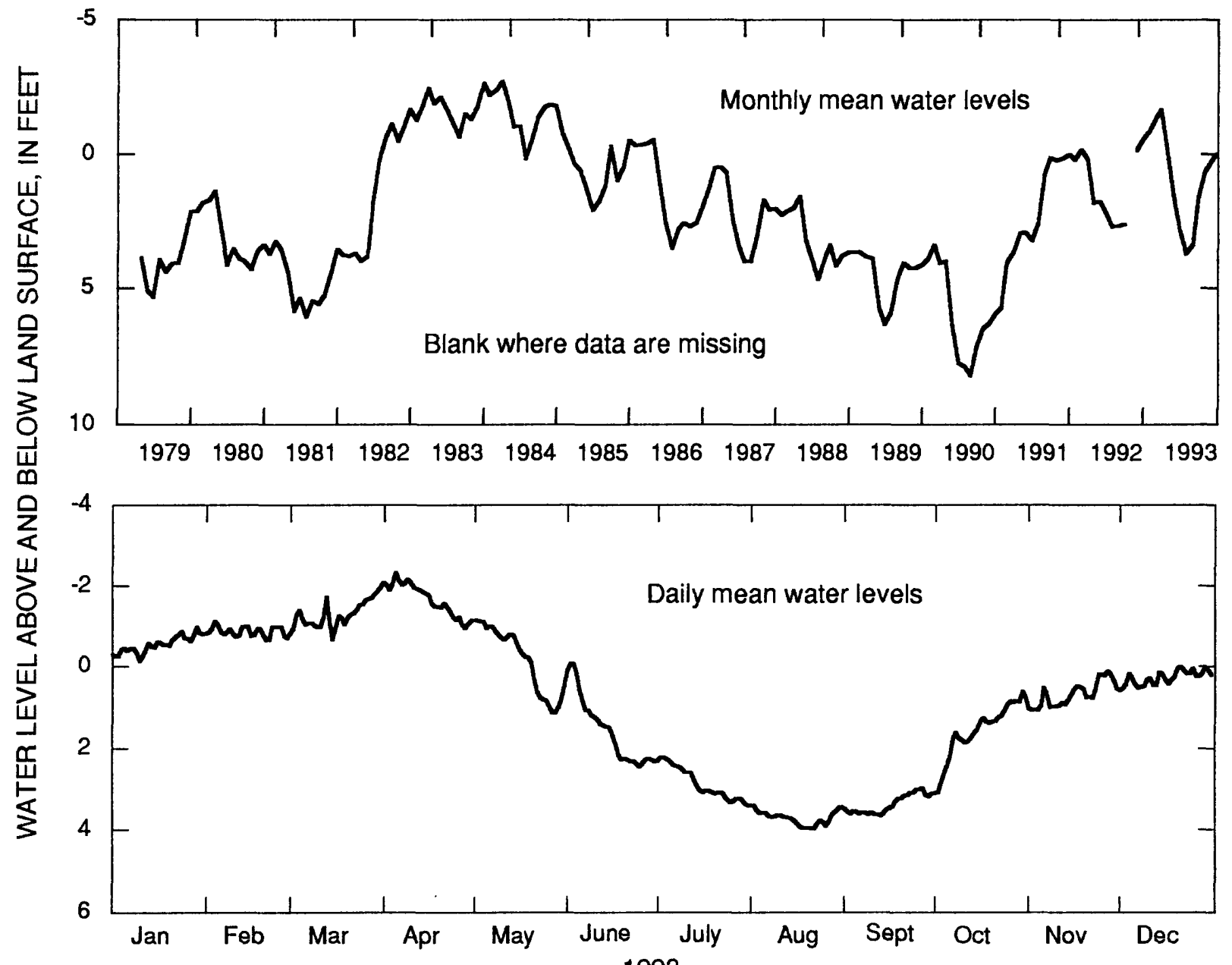

$\begin{array}{rrrrrrrrrrrrr}1993 & \text { JAN } & \text { FEB } & \text { MAR } & \text { APR } & \text { MAY } & \text { JUNE } & \text { JULY } & \text { AUG } & \text { SEPT } & \text { OCT } & \text { NOV } & \text { DEC } \\ \text { MEAN } & -0.53 & -0.85 & -1.27 & -1.66 & -0.17 & 1.56 & 2.87 & 3.72 & 3.39 & 1.60 & 0.68 & 0.29 \\ \text { LOW } & -0.13 & -0.63 & -0.66 & -0.94 & 1.14 & 2.45 & 3.42 & 3.98 & 3.67 & 3.09 & 1.08 & 0.55 \\ \text { HIGH } & -0.96 & -1.10 & -1.96 & -2.33 & -1.12 & -0.06 & 2.22 & 3.41 & 2.99 & 0.63 & 0.12 & 0.01 \\ \text { AL YR } & 1993 & & \text { MEAN } & 0.81 & & \text { HIGH } & -2.33 & & \text { LOW } & 3.98 & & \end{array}$

[Negative value indicates water level above land surface]

Figure 62.--Water level in observation well 33J044, Glynn County. 


\section{Claiborne Aquifer}

The water level in the Claiborne aquifer was monitored in 21 wells in 1993 ; data from eight of these wells (fig. 63) are summarized in figures 64-71. The water level in the aquifer is affected mainly by precipitation and by local and regional pumping (Hicks and others, 1981). The water level generally is highest following the winter and spring rainy seasons, and lowest in the fall following the summer irrigation season. The annual mean water levels in five of the eight wells were lower in 1993 than in 1992 (figs. 64-71). Water levels in the eight wells ranged from $7.9 \mathrm{ft}$ lower to $0.9 \mathrm{ft}$ higher in 1993 than in 1992. A record high daily mean water level was recorded in well 09M009 (fig. 65) in April that was $0.7 \mathrm{ft}$ higher than the previous record high. 


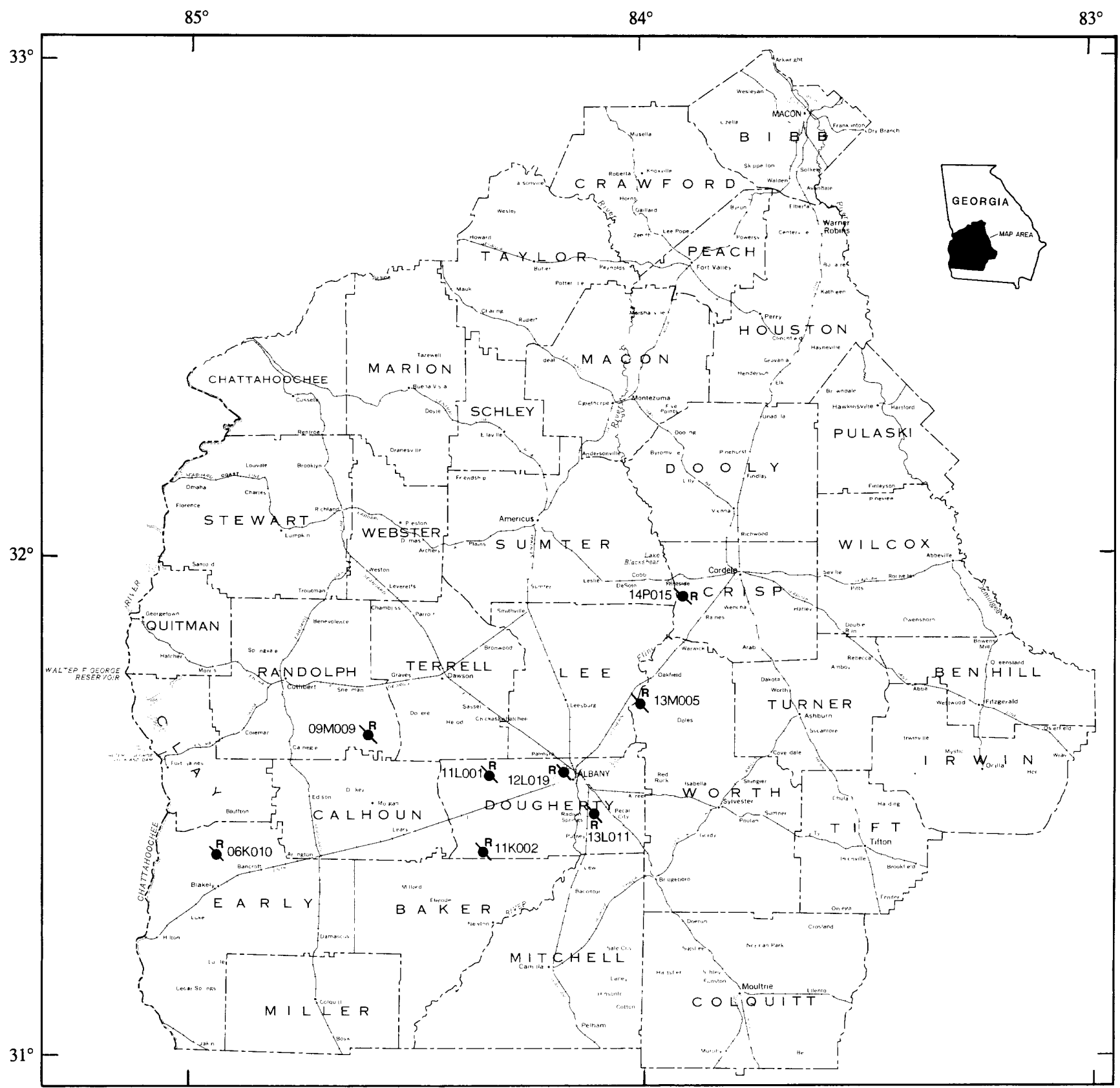

Base from U.S. Geological Survey State base map, 1970

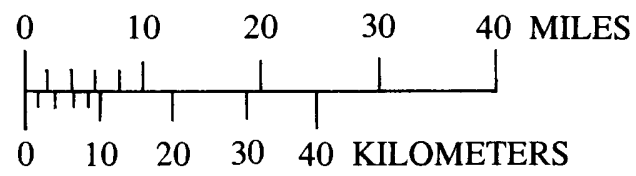

EXPLANATION

$a^{11 K 002}$ OBSERVATION WELL AND IDENTIFICATION NUMBER--Equipped with recorder, hydrograph included in this report

Figure 63.--Locations of observation wells completed in the Claiborne aquifer. 
312827084551503 Local number, 06K010.

LOCATION.--Lat $31^{\circ} 28^{\prime} 24^{\prime \prime}$, long $84^{\circ} 55^{\prime} 09^{\prime \prime}$, Hydrologic Unit 03130004.

Owner: Georgia Geologic Survey, Kolomoki Mounds State Park test well 3.

INSTRUMENTATION.--Digital recorder.

AQUIFER.--Claiborne.

WELL CHARACTERISTICS.--Drilled observation well, diameter 4 in., depth $140 \mathrm{ft}$, cased to $120 \mathrm{ft}$, screen to $140 \mathrm{ft}$.

DATUM.--Altitude of land-surface datum is $310 \mathrm{ft}$.

REMARKS.--Well pumped and redeveloped August 8, 1989.

PERIOD OF RECORD.--August 1984 to current year.

EXTREMES FOR PERIOD OF RECORD.--Highest water level, $73.11 \mathrm{ft}$ below land-surface datum, April 3, 1990; lowesh,

$77.35 \mathrm{ft}$ below land-surface datum, November 14, 1986.

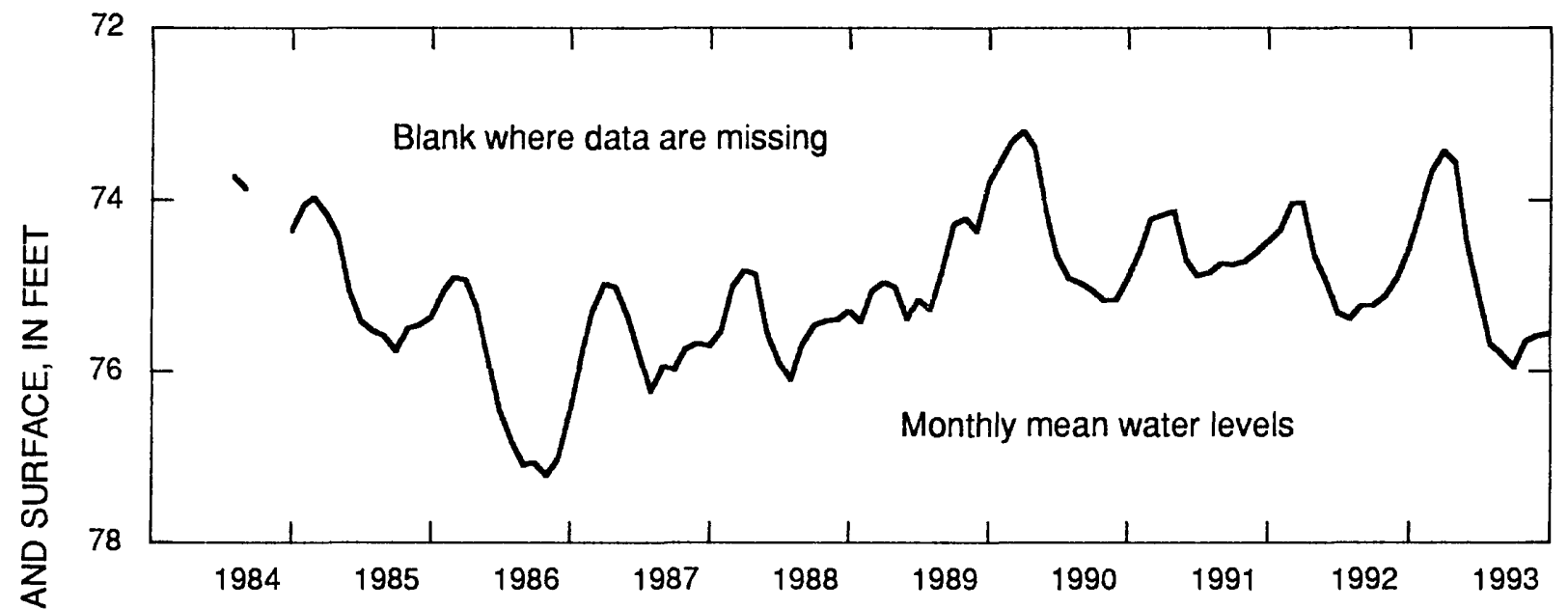

1993

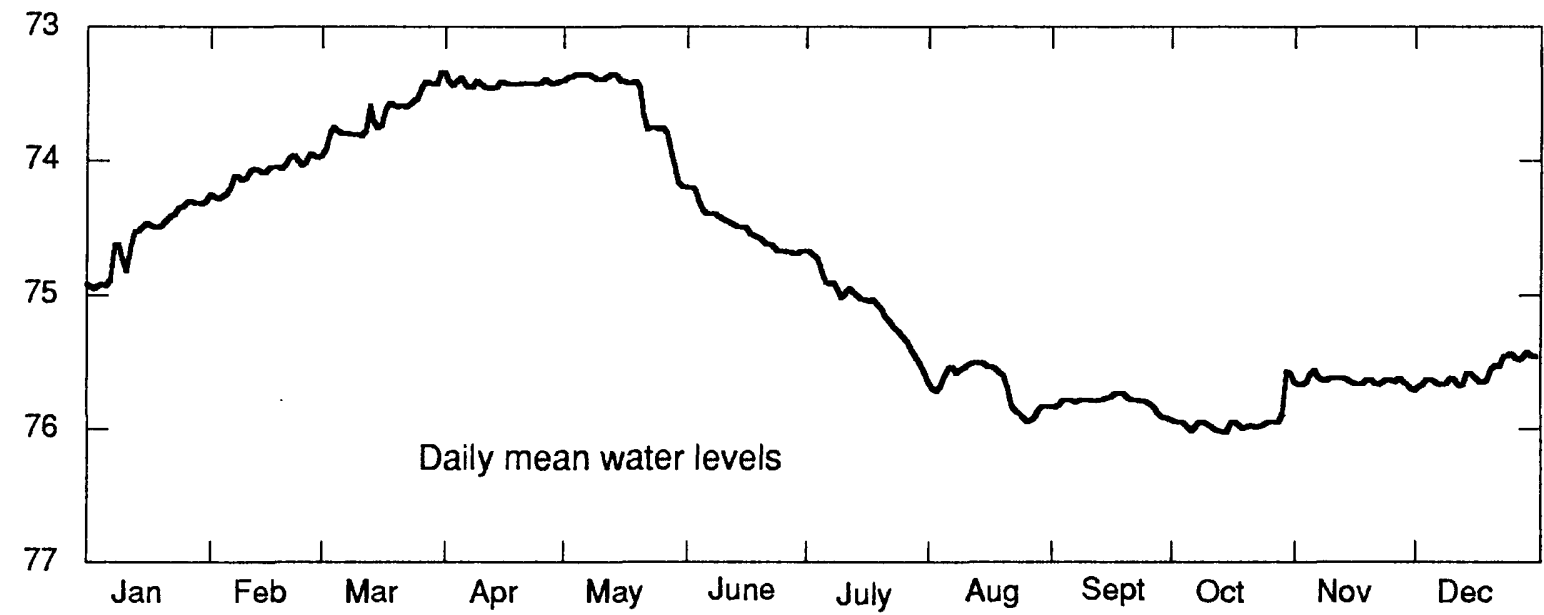
1993

$\begin{array}{lllllllllllll}\text { MEAN } & 74.57 & 74.09 & 73.66 & 73.42 & 73.56 & 74.50 & 75.08 & 75.69 & 75.81 & 75.95 & 75.65 & 75.59 \\ \text { LOW } & 74.96 & 74.28 & 73.92 & 73.46 & 74.19 & 74.69 & 75.59 & 75.95 & 75.93 & 76.03 & 75.71 & 75.70 \\ \text { HIGH } & 74.30 & 73.95 & 73.34 & 73.38 & 73.35 & 74.20 & 74.68 & 75.51 & 75.74 & 75.58 & 75.57 & 75.43 \\ \text { CAL YR } & 1993 & & \text { MEAN } & 74.80 & & \text { HIGH } & 73.34 & & \text { LOW } & 76.03 & & \end{array}$

Figure 64.--Water level in observation well 06K010, Early County. 
313953084361201 Local number, 09M009.

LOCATION.--Lat 31'39'52", long 84'36'10", Hydrologic Unit 03130009.

Owner: C.T. Martin, test well 1.

INSTRUMENTATION.--Digital recorder.

AQUIFER.--Claibome.

WELL CHARACTERISTICS.--Drilled observation well, diameter 4 in., depth $94 \mathrm{ft}$, cased to $77 \mathrm{ft}$, screen to $94 \mathrm{ft}$.

DATUM.--Altitude of land-surface datum is $322 \mathrm{ft}$.

REMARKS.--Well pumped and redeveloped August 8, 1989.

PERIOD OF RECORD.--September 1984 to current year.

EXTREMES FOR PERIOD OF RECORD.--Highest water level, $24.30 \mathrm{ft}$ below land-surface datum, April 1, 1993; lowest, $30.50 \mathrm{ft}$ below land-surface datum, November 3, 1986.

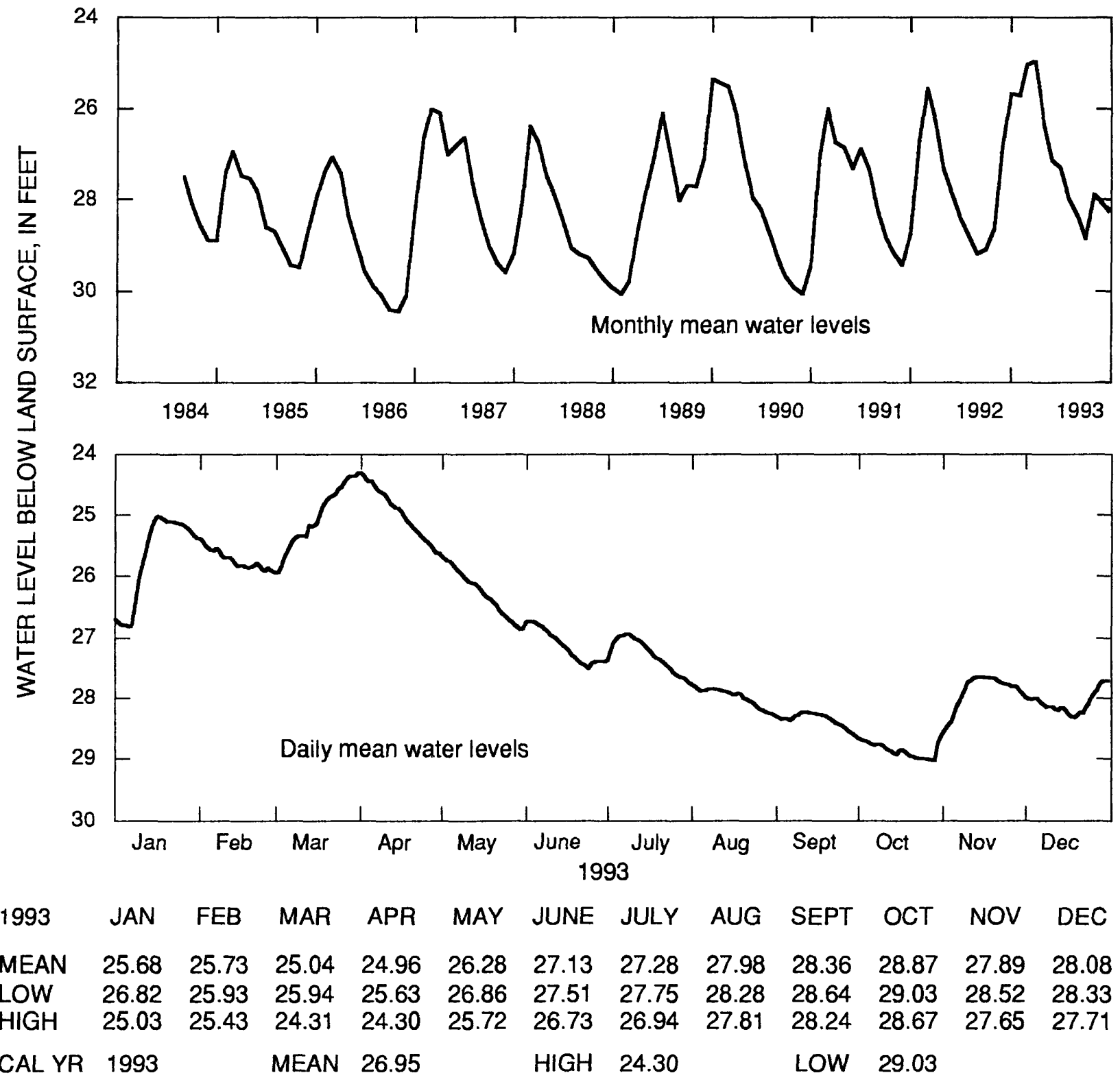

Figure 65.--Water level in observation well 09M009, Randolph County. 
312654084210102 Local number, $11 \mathrm{~K} 002$.

LOCATION.--Lat $31^{\circ} 26^{\prime} 54^{\prime \prime}$, long $84^{\circ} 21^{\prime} 01^{\prime \prime}$, Hydrologic Unit 03130008.

Owner: U.S. Geological Survey, test well 11.

INSTRUMENTATION.--Digital recorder.

AQUIFER.--Claiborne.

WELL CHARACTERISTICS.--Drilled observation well, diameter 4 in., depth $320 \mathrm{ft}$, cased to $300 \mathrm{ft}$, screen to $320 \mathrm{ft}$.

DATUM.--Altitude of land-surface datum is $183.5 \mathrm{ft}$.

REMARKS.--Borehole geophysical survey conducted March 11, 1980. Water levels for periods of missing record, January 13-16, 22-26, April 3 to May 13, 23-29, June 11 to July 8, 11-12, 20-28, August 2, 5-10, 27 to September 22, October 5-8, November 4-5, 17-20, 23, and December 23-25, were estimated.

PERIOD OF RECORD.--May 1979 to current year.

EXTREMES FOR PERIOD OF RECORD.--Highest water level, $22.11 \mathrm{ft}$ below land-surface datum, June 1, 1979; lowest, $28.04 \mathrm{ft}$ below land-surface datum, December 24, 1981.
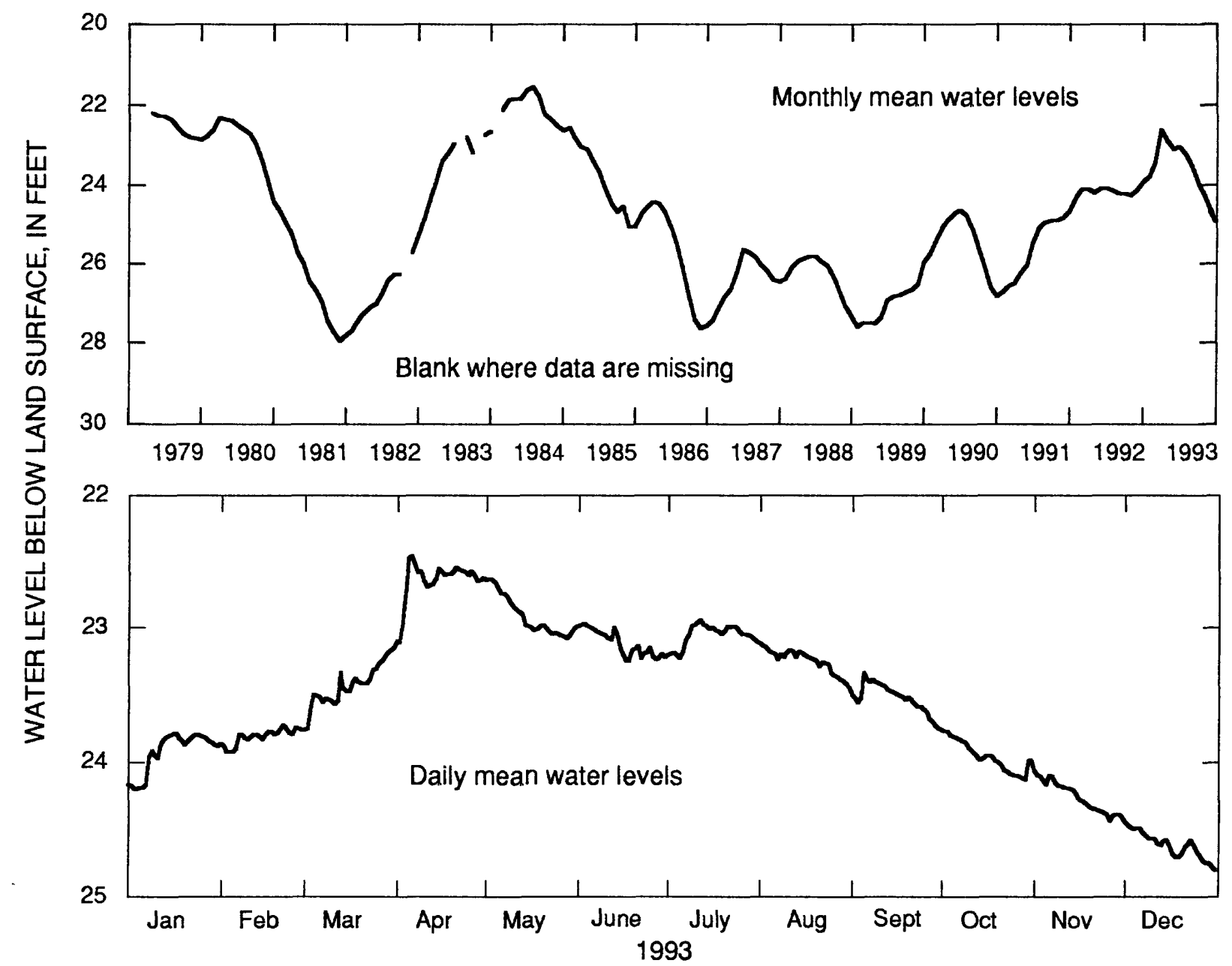

\begin{tabular}{|c|c|c|c|c|c|c|c|c|c|c|c|c|}
\hline 1993 & JAN & FEB & MAR & APR & MAY & JUNE & JULY & AUG & SEPT & OCT & NOV & DEC \\
\hline MEAN & 23.92 & 23.81 & 23.43 & 22.64 & 22.91 & 23.12 & 23.06 & 23.25 & 23.53 & 23.95 & 24.26 & 24.62 \\
\hline $\begin{array}{l}\text { LOW } \\
\text { HIGH }\end{array}$ & $\begin{array}{l}24.20 \\
23.78\end{array}$ & $\begin{array}{l}23.92 \\
23.72\end{array}$ & $\begin{array}{l}23.75 \\
23.15\end{array}$ & $\begin{array}{l}23.11 \\
22.45\end{array}$ & $\begin{array}{l}23.08 \\
22.63\end{array}$ & $\begin{array}{l}23.25 \\
22.97\end{array}$ & $\begin{array}{l}23.23 \\
22.94\end{array}$ & $\begin{array}{l}23.45 \\
23.14\end{array}$ & $\begin{array}{l}23.75 \\
23.34\end{array}$ & $\begin{array}{l}24.13 \\
23.77\end{array}$ & $\begin{array}{l}24.44 \\
24.10\end{array}$ & $\begin{array}{l}24.81 \\
24.47\end{array}$ \\
\hline CAL YR & 1993 & & MEAN & 23.54 & & $\mathrm{HIGH}$ & $22.45^{\star}$ & & LOW & 24.81 & & \\
\hline
\end{tabular}

Figure 66.--Water level in observation well 11K002, Dougherty County. 
313530084203202 Local number, $11 \mathrm{~L} 001$.

LOCATION.--Lat $31^{\circ} 35^{\prime} 30^{\prime \prime}$, long $84^{\circ} 20^{\prime} 34^{\prime \prime}$, Hydrologic Unit 03130008.

Owner: U.S. Geological Survey, test well 4.

INSTRUMENTATION.--Digital recorder.

AQUIFER.--Claiborne.

WELL CHARACTERISTICS.--Drilled observation well, diameter 4 in., depth $251 \mathrm{ft}$, cased to $233 \mathrm{ft}$, screen to $251 \mathrm{ft}$.

DATUM.--Altitude of land-surface datum is $220 \mathrm{ft}$.

REMARKS.--Well pumped and redeveloped August 14, 1988.

PERIOD OF RECORD.--March 1978 to current year.

EXTREMES FOR PERIOD OF RECORD.--Highest water level, $12.11 \mathrm{ft}$ below land-surface datum, June 5-6, 1978; lowest,

$34.75 \mathrm{ft}$ below land-surface datum, October 19-20, 1986.

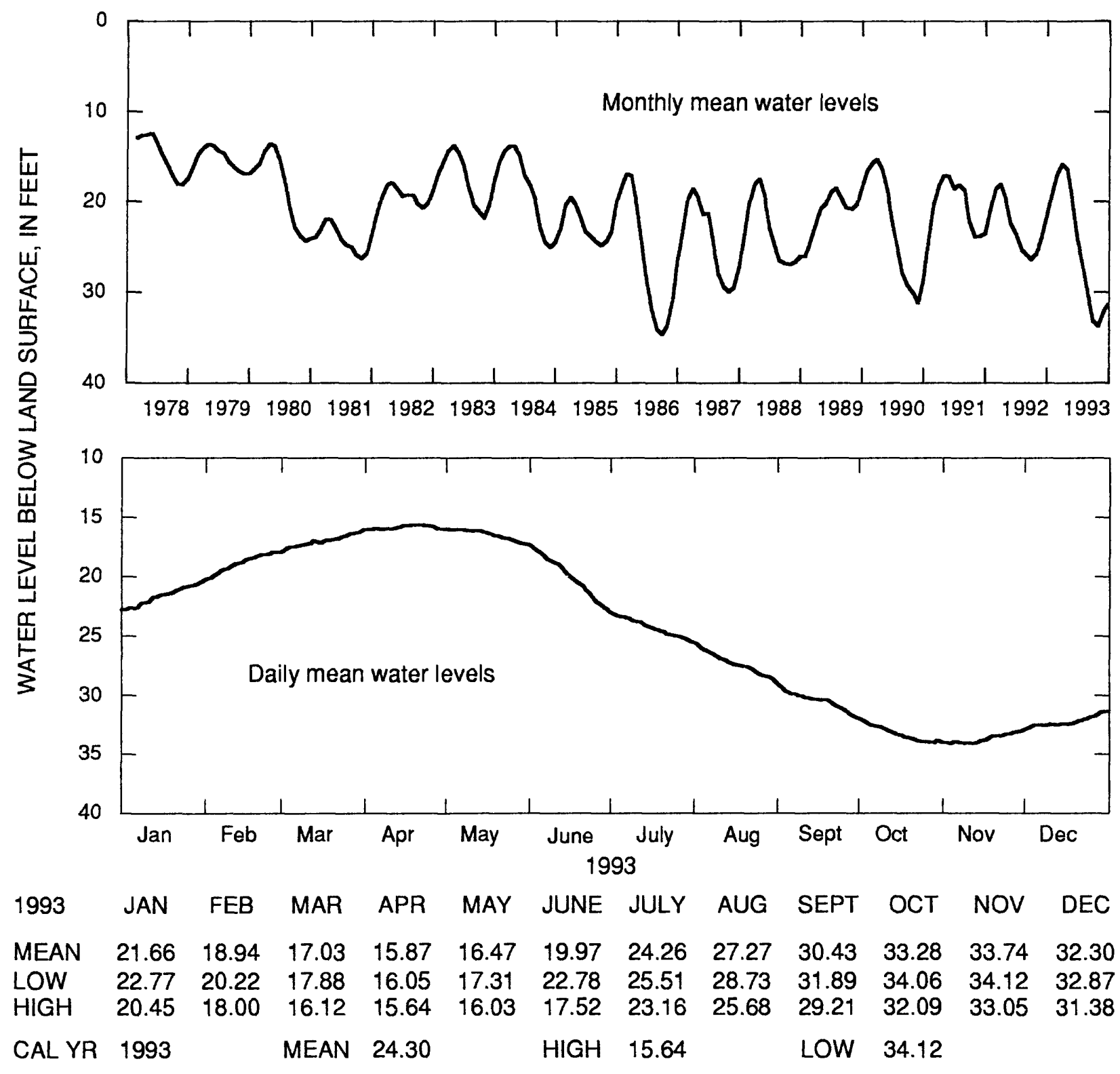

Figure 67.--Water level in observation well 11L001, Dougherty County. 
313534084103001 Local number, 12 L019.

LOCATION.--Lat 31 '35'36", long 84¹0'30", Hydrologic Unit 03130008.

Owner: U.S. Geological Survey, test well 5.

INSTRUMENTATION.--Electronic data recorder.

AQUIFER.--Claiborne.

WELL CHARACTERISTICS.--Drilled observation well, diameter 4 in., depth $257 \mathrm{ft}$ cased to $241 \mathrm{ft}$, screen to $257 \mathrm{ft}$.

DATUM.--Altitude of land-surface datum is $198 \mathrm{ft}$.

REMARKS.--Well pumped and redeveloped August 15, 1988.

PERIOD OF RECORD.--March 1978 to current year.

EXTREMES FOR PERIOD OF RECORD.--Highest water level, $57.31 \mathrm{ft}$ below land-surface datum, April 7, 1992; lowest, $99.53 \mathrm{ft}$ below land-surface datum, August 1-2, 1978.

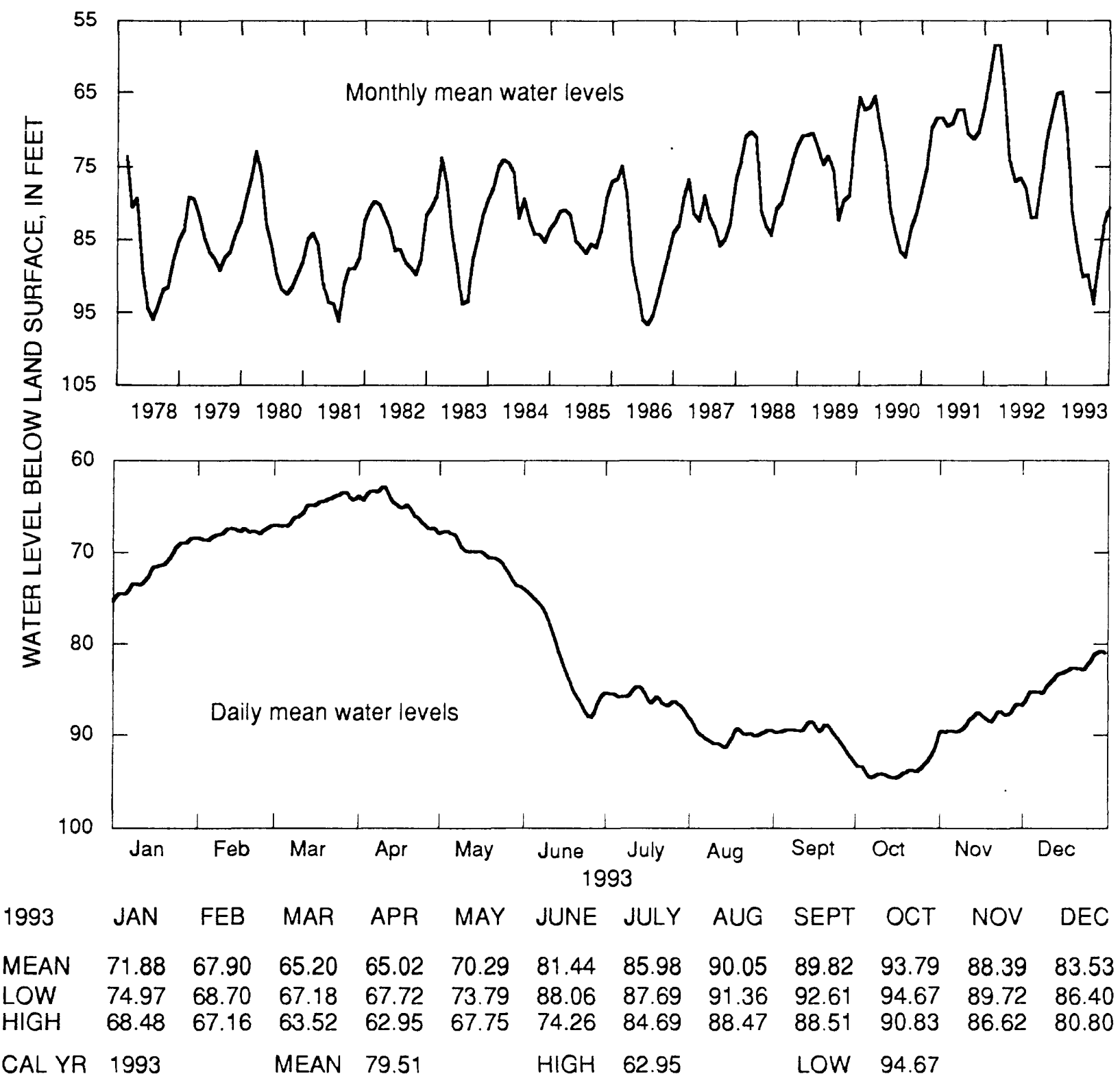

Figure 68.--Water level in observation well 12L019, Dougherty County. 
313105084064301 Local number, $13 \mathrm{~L} 011$.

LOCATION.--Lat $31^{\circ} 31^{\prime} 05^{\prime \prime}$, long 84 $06^{\prime} 43^{\prime \prime}$, Hydrologic Unit 03130008.

Owner: U.S. Geological Survey, test well 2.

INSTRUMENTATION.--Electronic data recorder.

AQUIFER.--Claiborne.

WELL CHARACTERISTICS.--Drilled observation well, diameter 4 in., depth $418 \mathrm{ft}$, cased to $398 \mathrm{ft}$, screen to $418 \mathrm{ft}$. DATUM.--Altitude of land-surface datum is $195 \mathrm{ft}$.

REMARKS.--Well pumped and redeveloped August 16, 1988. Water levels for periods of missing record, August 3-12 and September 10-29, were estimated.

PERIOD OF RECORD.--June 1977 to current year.

EXTREMES FOR PERIOD OF RECORD.--Highest water level, $60.01 \mathrm{ft}$ below land-surface datum, April 5, 1978; lowest, $95.00 \mathrm{ft}$ below land-surface datum, August 9-11, 1981.

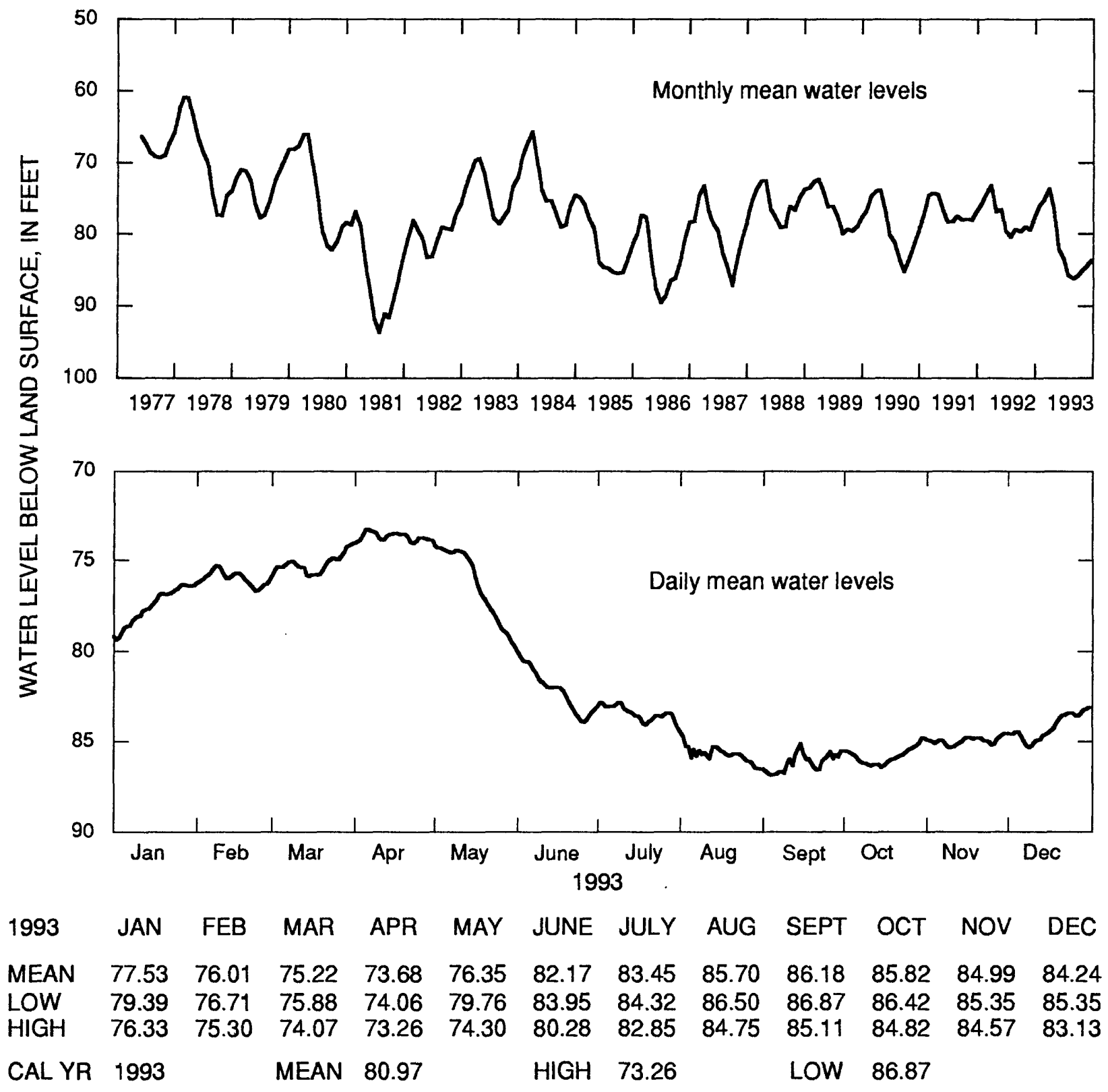

Figure 69.--Water level in observation well 13L011, Dougherty County. 
314330084005401 Local number, 13M005.

LOCATION.--Lat $31^{\circ} 43^{\prime} 30^{\prime \prime}$, long $84^{\circ} 00^{\prime} 54^{\prime \prime}$, Hydrologic Unit 03130006.

Owner: U.S. Geological Survey, test well DP-7.

INSTRUMENTATION.--Digital recorder.

AQUIFER.--Claiborne.

WELL CHARACTERISTICS.--Drilled observation well, diameter $6 \mathrm{in}$., depth $345 \mathrm{ft}$, cased to $330 \mathrm{ft}$, screen to $345 \mathrm{ft}$.

DATUM.--Altitude of land-surface datum is $230 \mathrm{ft}$.

REMARKS.--Borehole geophysical survey conducted March 16, 1982.

PERIOD OF RECORD.--April 1980 to current year.

EXTREMES FOR PERIOD OF RECORD.--Highest water level, $2.89 \mathrm{ft}$ below land-surface datum, May 29, 1980; lowest,

$23.37 \mathrm{ft}$ below land-surface datum July 28,1981 .
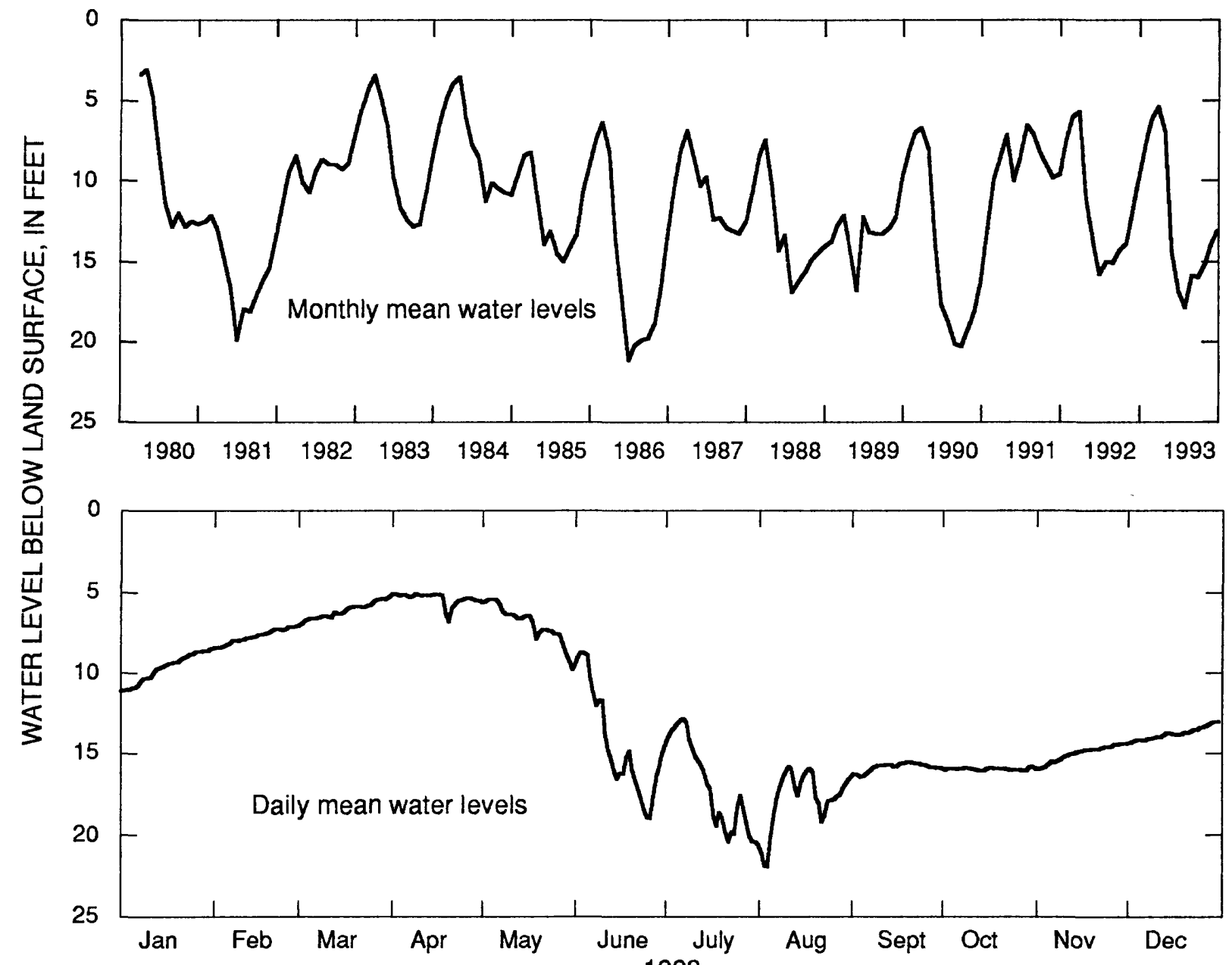

$\begin{array}{rrrrrrrrrrrrr}1993 & \text { JAN } & \text { FEB } & \text { MAR } & \text { APR } & \text { MAY } & \text { JUNE } & \text { JULY } & \text { AUG } & \text { SEPT } & \text { OCT } & \text { NOV } & \text { DEC } \\ \text { MEAN } & 9.73 & 7.75 & 6.16 & 5.40 & 6.91 & 14.34 & 16.90 & 17.84 & 15.88 & 15.98 & 15.07 & 13.82 \\ \text { LOW } & 11.14 & 8.44 & 6.96 & 6.80 & 9.79 & 18.98 & 20.43 & 21.92 & 16.46 & 16.06 & 15.97 & 14.37 \\ \text { HIGH } & 8.53 & 7.12 & 5.31 & 5.10 & 5.44 & 8.73 & 12.89 & 15.84 & 15.57 & 15.83 & 14.43 & 13.08 \\ \text { AL YR } & 1993 & & \text { MEAN } & 12.18 & & \text { HIGH } & 5.10 & & \text { LOW } & 21.92 & & \end{array}$

Figure 70.--Water level in observation well 13M005, Worth County. 
315731083542302 Local number, 14P015.

LOCATION.--Lat $31^{\circ} 57^{\prime} 31^{\prime \prime}$, long 8354'23", Hydrologic Unit 03130006.

Owner: Georgia Geologic Survey, Veterans Memorial State Park test well 2.

INSTRUMENTATION.--Digital recorder.

AQUIFER.-- Claiborne.

WELL CHARACTERISTICS.--Drilled observation well, diameter 6 in., depth $340 \mathrm{ft}$, cased to $240 \mathrm{ft}$, screen to $340 \mathrm{ft}$.

DATUM.--Altitude of land-surface datum is $252 \mathrm{ft}$.

REMARKS.--Aquifer test conducted on April 22, 1982. Well Pumped and sampled by Georgia Geologic Survey, September $23,1992$.

PERIOD OF RECORD.--August 1984 to current year.

EXTREMES FOR PERIOD OF RECORD.--Highest water level, $12.97 \mathrm{ft}$ below land-surface datum, March 9, 1987; lowest, $42.09 \mathrm{ft}$ below land-surface datum, September 2, 1990.

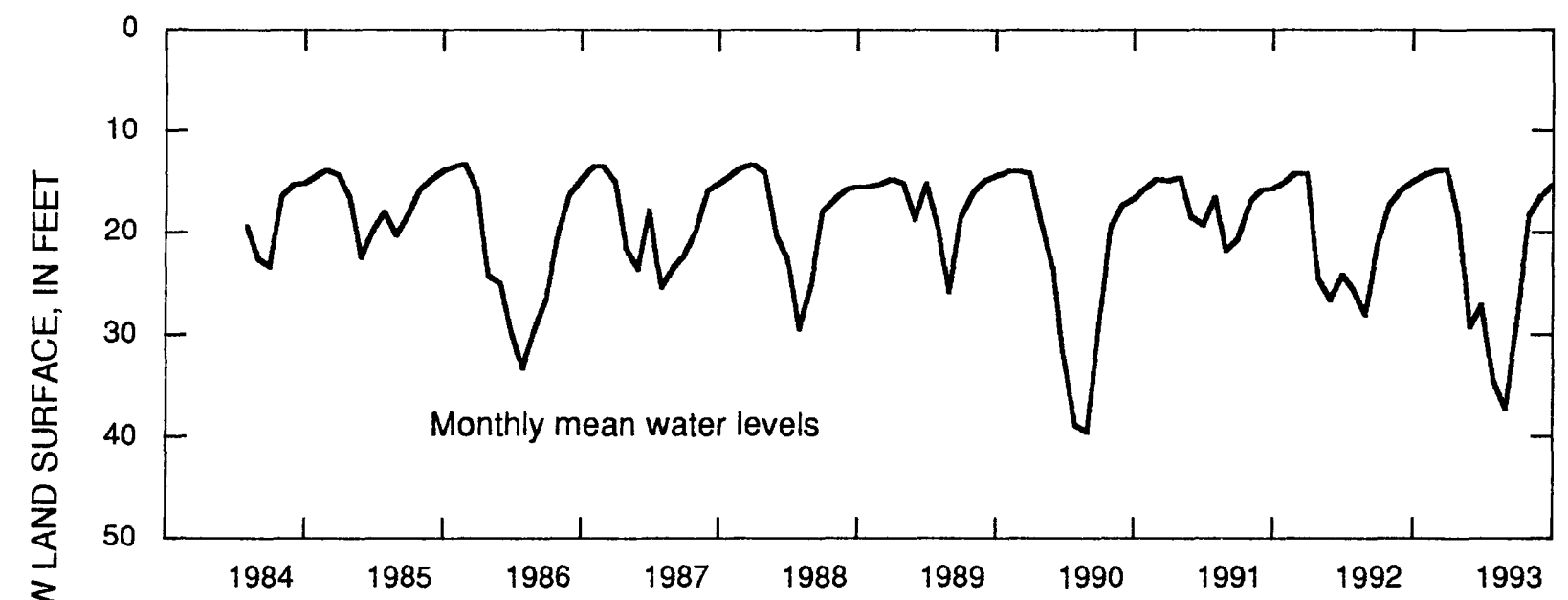

$\begin{array}{lcccccccccccc}1993 & \text { JAN } & \text { FEB } & \text { MAR } & \text { APR } & \text { MAY } & \text { JUNE } & \text { JULY } & \text { AUG } & \text { SEPT } & \text { OCT } & \text { NOV } & \text { DEC } \\ \text { MEAN } & 14.96 & 14.39 & 13.95 & 13.83 & 18.65 & 29.35 & 27.10 & 34.52 & 37.22 & 29.05 & 18.34 & 16.57 \\ \text { LOW } & 15.39 & 14.61 & 14.20 & 14.29 & 24.09 & 33.59 & 32.64 & 38.76 & 40.46 & 35.40 & 20.52 & 17.07 \\ \text { HIGH } & 14.65 & 14.23 & 13.64 & 13.64 & 14.50 & 24.69 & 22.81 & 30.86 & 35.27 & 21.10 & 17.15 & 16.19 \\ \text { CAL YR } & 1993 & & \text { MEAN } & 22.37 & & \text { HIGH } & 13.62 & & \text { LOW } & 40.46 & & \end{array}$

Figure 71.--Water level in observation well 14P015, Crisp County. 


\section{Clayton Aquifer}

The water level in the Clayton aquifer was monitored in 12 wells in 1993; data from seven of these wells (fig. 72) are summarized in figures 73-79. Water levels in wells tapping the aquifer are affected by seasonal variations in local and regional pumping (Hicks and others, 1981).

Annual mean water levels in the seven wells monitored for this report (figs. 73-79) ranged from about 1.1 to $9.6 \mathrm{ft}$ lower in 1993 than in 1992. Record-low daily mean water levels were recorded in wells 06K009 (fig. 73), 07N001 (fig. 74), 09N001 (fig. 75), and 11 K005 (fig. 78) that ranged from $0.9 \mathrm{ft}$ to $7.2 \mathrm{ft}$ lower than the previous record lows. 


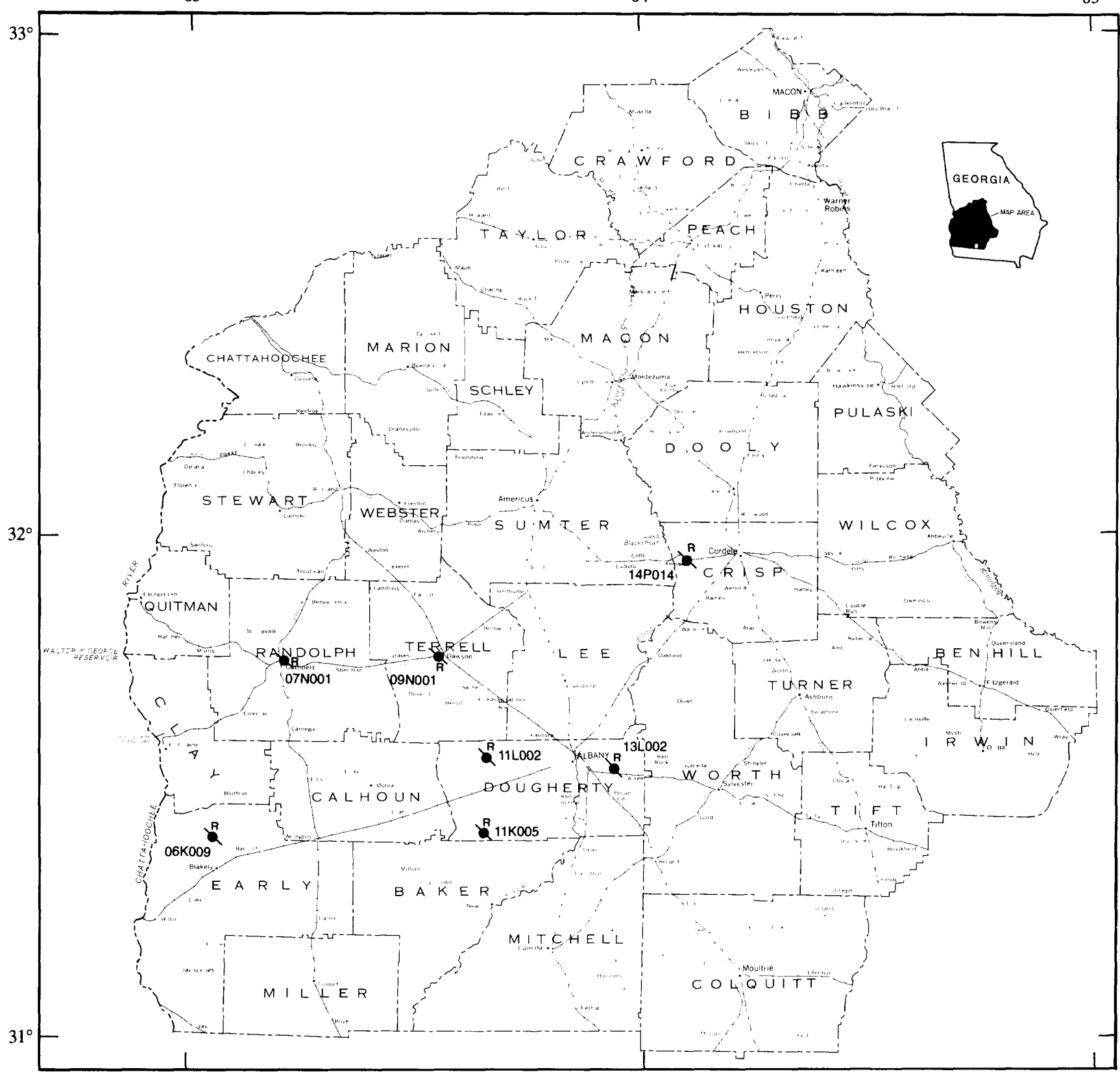

Base from U.S. Geological Survey State base map, 1970

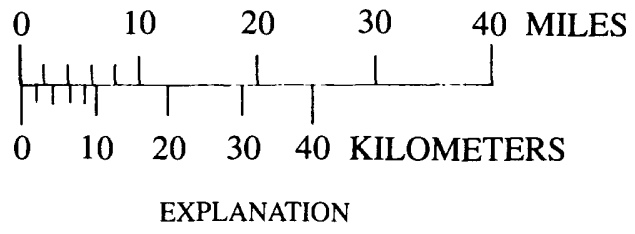

1K005 OBSERVATION WELL AND IDENTIFICATION NUMBER--Equipped with recorder, hydrograph included in this report

Figure 72.--Locations of observation wells completed in the Clayton aquifer. 
312827084551501 Local number, 06K009.

LOCATION.--Lat $31^{\circ} 28^{\prime 2} 24^{\prime \prime}$ long $84^{\circ} 55^{\prime} 12 "$ ", Hydrologic Unit 03130004.

Owner: Georgia Geologic Survey, Kolomoki Mounds State Park test well 1.

INSTRUMENTATION.--Digital recorder.

AQUIFER.--Clayton.

WELL CHARACTERISTICS.--Drilled observation well, diameter 6 in., depth $612 \mathrm{ft}$, cased to $491 \mathrm{ft}$, open hole.

DATUM.--Altitude of land-surface datum is $310 \mathrm{ft}$.

REMARK.--Borehole geophysical survey conducted November 20, 1979. Aquifer test conducted May 19, 1982. Well pumped and redeveloped August 8, 1989. Water levels for period of missing record, September 6-25, were estimated.

PERIOD OF RECORD.--August 1984 to current year.

EXTREMES FOR PERIOD OF RECORD.--Highest water level, $146.62 \mathrm{ft}$ below land-surface datum, April 3, 1986; lowest,

$174.69 \mathrm{ft}$ below land-surface datum, September 31, 1993.

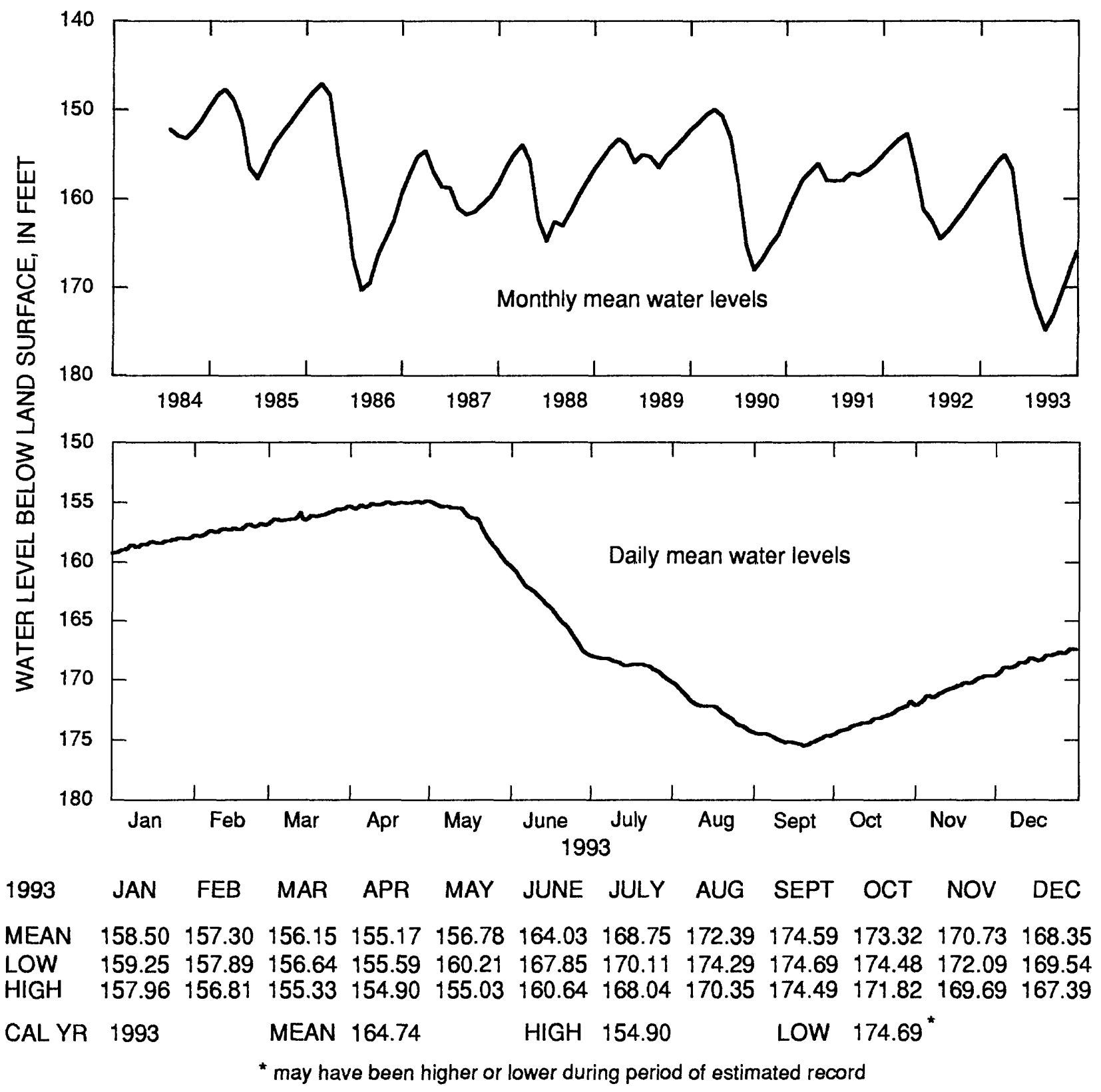

Figure 73.--Water level in observation well 06K009, Early County. 
314602084473701 Local number, $07 \mathrm{~N} 001$.

LOCATION.--Lat $31^{\circ} 46^{\prime} 09^{\prime \prime}$ long 84 $47^{\prime} 43^{\prime \prime}$, Hydrologic Unit 03110204.

Owner: City of Cuthbert.

INSTRUMENTATION.--Digital recorder.

AQUIFER.--Clayton.

WELL CHARACTERISTICS.--Drilled unused municipal well, diameter $8 \mathrm{in}$., depth $372 \mathrm{ft}$, casing depth unknown.

DATUM.--Altitude of land-surface datum is $460 \mathrm{ft}$.

REMARKS.--Well pumped and redeveloped August 8, 1989. Well near city wells.

PERIOD OF RECORD.--January 1965 to current year.

EXTREMES FOR PERIOD OF RECORD.--Highest water level, $132.0 \mathrm{ft}$ below land-surface datum, December 10, 1967; lowest,

$163.00 \mathrm{ft}$ below land-surface datum, August 23, 1993.

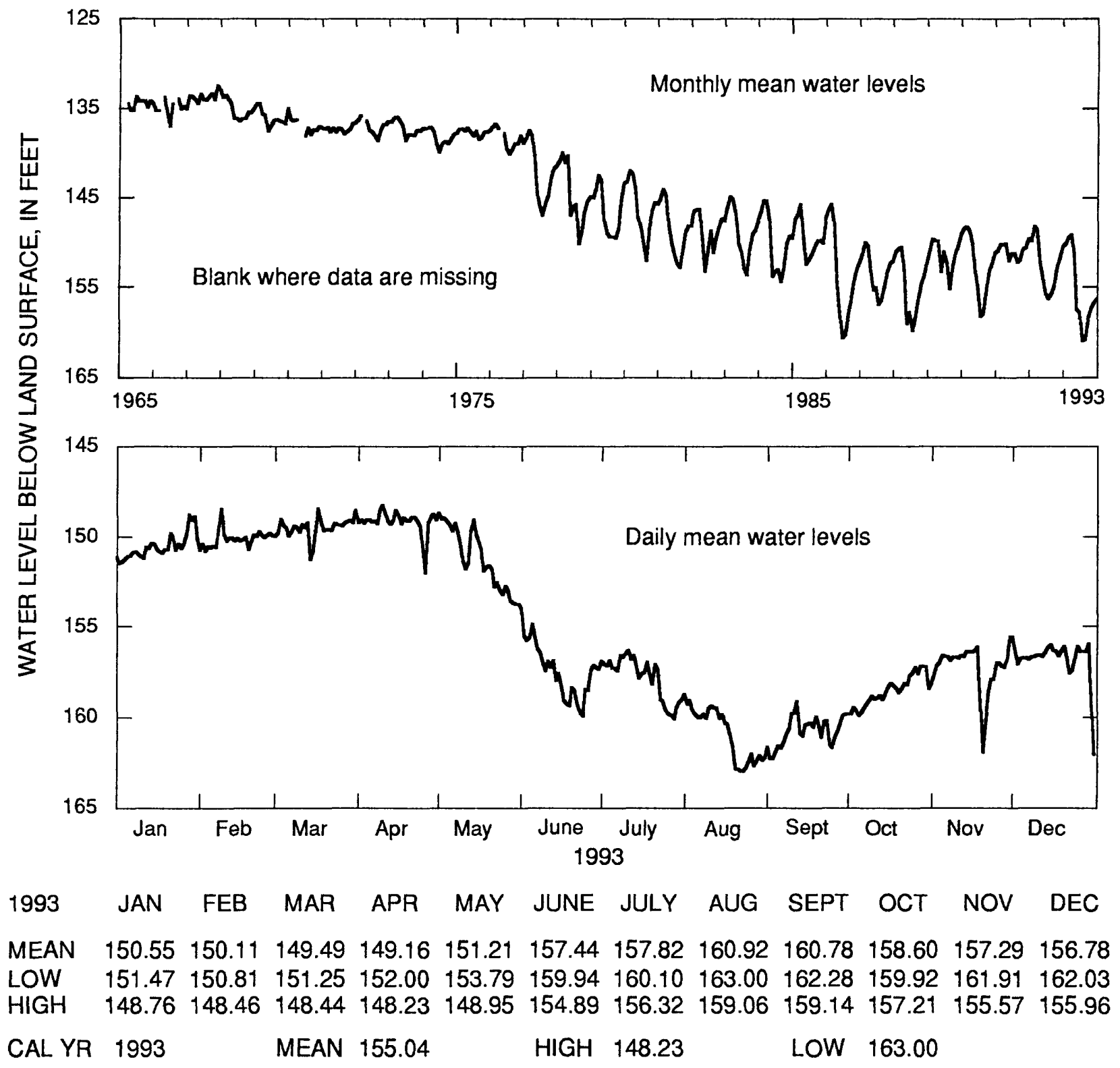

Figure 74.--Water level in observation well 07N001, Randolph County. 
314611084310301 Local number, 09 N001.

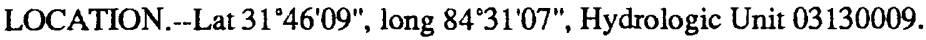

Owner: Bill Newman.

INSTRUMENTATION.--Digital recorder.

AQUIFER.--Clayton.

WELL CHARACTERISTICS.--Drilled unused supply well, diameter 6 in., depth $433 \mathrm{ft}$, cased to $333 \mathrm{ft}$, open hole.

DATUM.--Altitude of land-surface datum is $348 \mathrm{ft}$.

REMARKS.--Borehole geophysical survey conducted July 31, 1953. Well pumped and redeveloped August 9, 1989. Water levels for periods of missing record, February 15-22, May 21 to June 8, 20 to July 8, August 19, September 3 to October 8, and December 22-31, were estimated.

PERIOD OF RECORD.--January 1982 to current year.

EXTREMES FOR PERIOD OF RECORD.--Highest water level, $142.54 \mathrm{ft}$ below land-surface datum, February 10, 1992;

lowest, $248.83 \mathrm{ft}$ below land-surface datum, August 31, 1993.

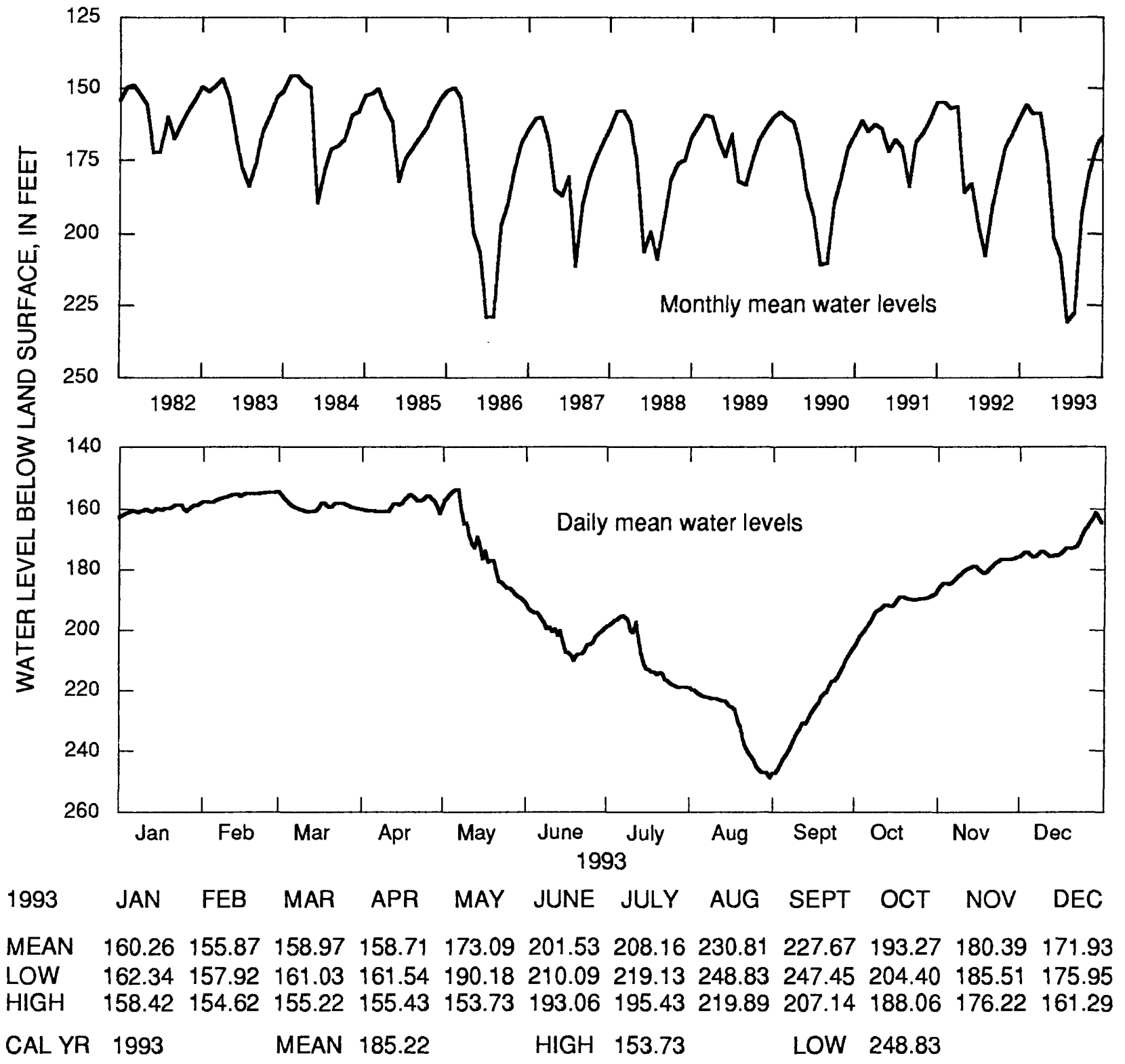

Figure 75.--Water level in observation well 09N001, Terrell County. 
313532084203501 Local number, $11 \mathrm{~L} 002$.

LOCATION.--Lat 31 35'32", long 84²0'35", Hydrologic Unit 03130008.

Owner: Georgia Geologic Survey, Albany Nursery.

INSTRUMENTATION.--Digital recorder.

AQUIFER.--Clayton.

WELL CHARACTERISTICS.--Drilled observation well, diameter 3 in., depth $656 \mathrm{ft}$, cased to $542 \mathrm{ft}$, open hole.

DATUM.--Altitude of land-surface datum is $222 \mathrm{ft}$.

REMARKS.--Well pumped and redeveloped August 14, 1988. Borehole geophysical survey conducted June 3, 1975. Water levels for periods of missing record, March 14-20, August 7-20, and September 13-22, were estimated.

PERIOD OF RECORD.--September 1973 to current year.

EXTREMES FOR PERIOD OF RECORD.--Highest water level, $58.90 \mathrm{ft}$ below land-surface datum, April 29, 1975; lowest, $152.61 \mathrm{ft}$ below land-surface datum, August 23, 1986.

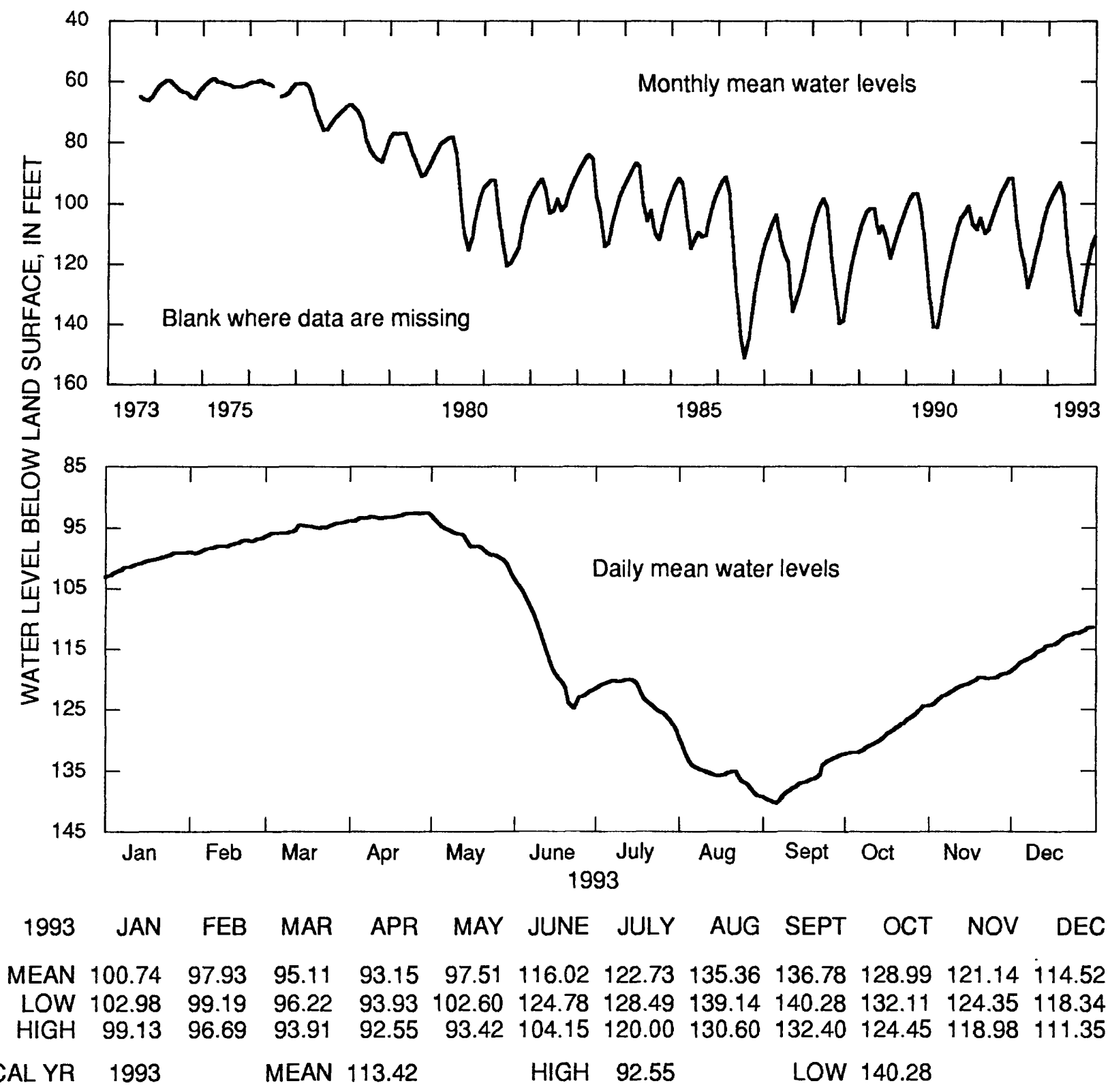

Figure 76.--Water level in observation well 11L002, Dougherty County. 
313554084062501 Local number, $13 \mathrm{~L} 002$.

LOCATION.--Lat $31^{\circ} 35^{\prime} 51^{\prime \prime}$, long 84 $06^{\circ} 24^{\prime \prime}$, Hydrologic Unit 03130008.

Owner: Albany Water, Gas, and Light Commission, Turner City 2.

INSTRUMENTATION.--Digital recorder.

AQUIFER.--Clayton.

WELL CHARACTERISTICS.--Drilled unused supply well, diameter $12 \mathrm{in}$., depth $760 \mathrm{ft}$, cased to $713 \mathrm{ft}$, open hole.

DATUM.--Altitude of land-surface datum is $212.84 \mathrm{ft}$.

REMARKS.--Well pumped and sounded to a depth of $760 \mathrm{ft}$ June 21, 1978; water-quality sample collected at conclusion of pumping. Borehole geophysical survey conducted March 17, 1977. Water levels for period of missing record, October 30 to November 23, were estimated. Well pumped and sampled by Georgia Geologic Survey, December 1, 1992.

PERIOD OF RECORD.--December 1957 to December 1959; January 1962 to current year.

EXTREMES FOR PERIOD OF RECORD.--Highest water level, $38.19 \mathrm{ft}$ below land-surface datum, April 1, 1959; lowest, $160.88 \mathrm{ft}$ below land-surface datum, July $26,1986$.

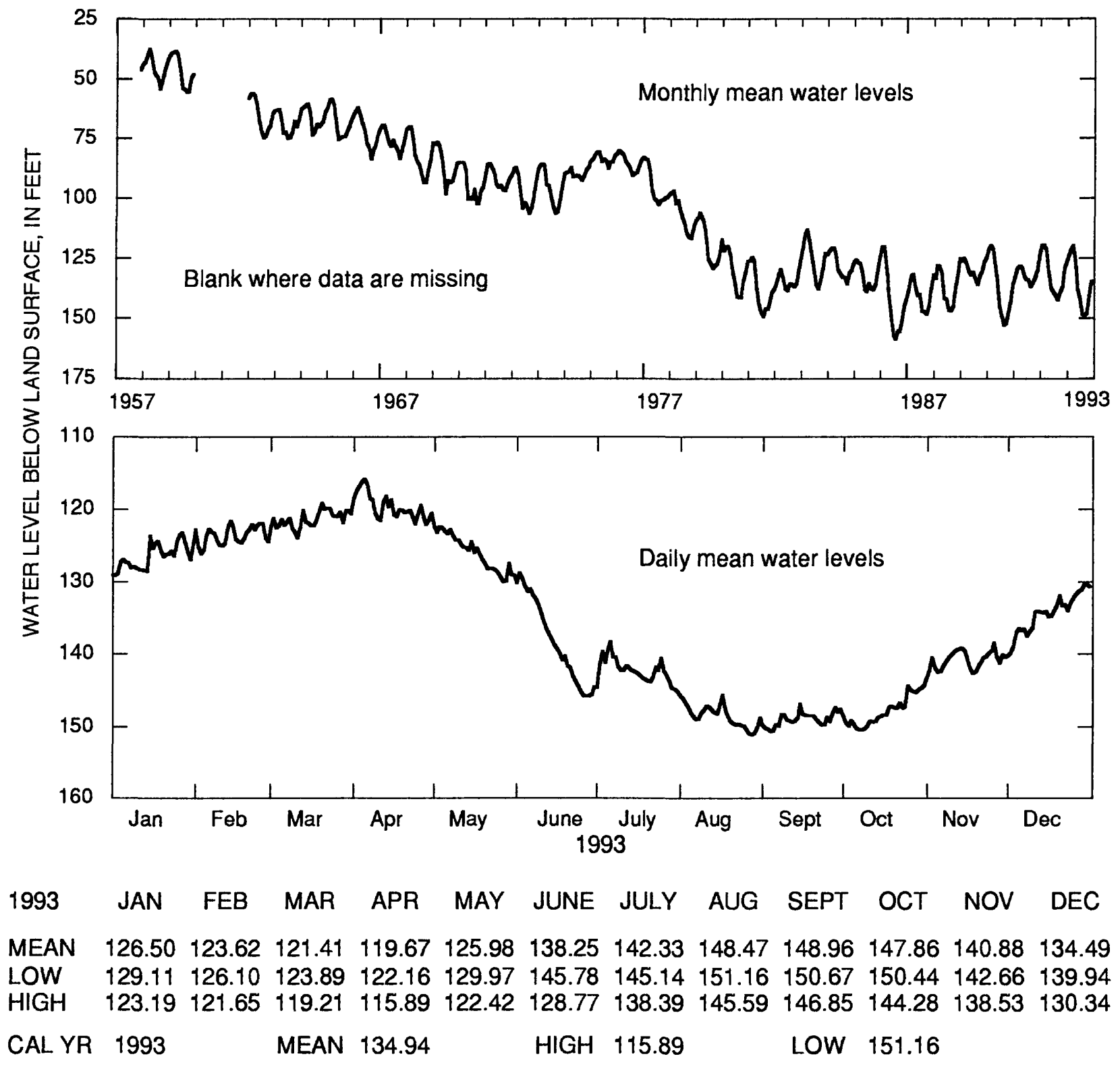

Figure 77.--Water level in observation well 13L002, Dougherty County. 
312654084210103 Local number, $11 \mathrm{~K} 005$.

LOCATION.--Lat $31^{\circ} 26^{\prime} 54^{\prime \prime}$, long $84^{\circ} 21^{\prime} 01^{\prime \prime}$, Hydrologic Unit 03130008.

Owner: U.S. Geological Survey, test well 12.

INSTRUMENTATION.--Digital recorder.

AQUIFER.--Clayton.

WELL CHARACTERISTICS.--Drilled observation well, diameter 6 in., depth $690 \mathrm{ft}$, cased to $630 \mathrm{ft}$, open hole.

DATUM.--Altitude of land-surface datum is $183 \mathrm{ft}$.

REMARKS.--Borehole geophysical survey conducted March 14, 1979.

PERIOD OF RECORD.--May 1979 to current year.

EXTREMES FOR PERIOD OF RECORD.--Highest water level, $23.03 \mathrm{ft}$ below land-surface datum, May 24, 1979; lowest, $60.10 \mathrm{ft}$ below land-surface datum, December 31, 1993.

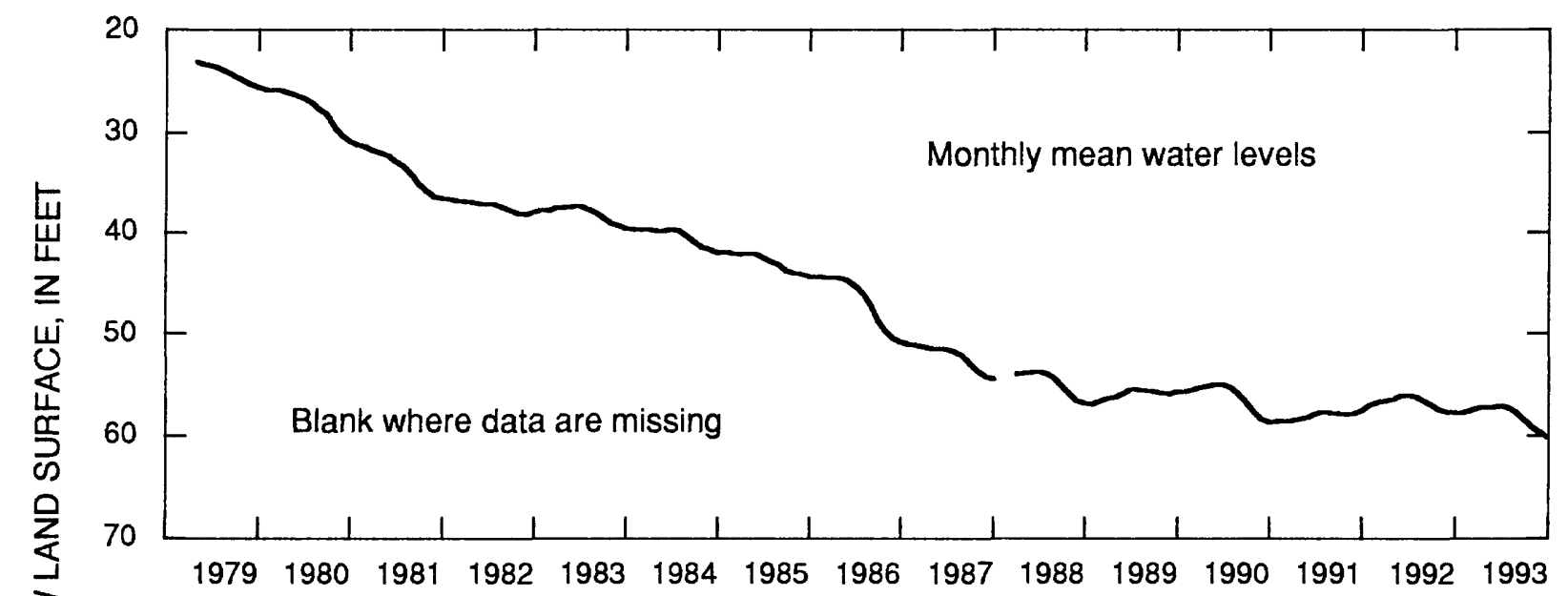

$\begin{array}{lcccccccccccc}1993 & \text { JAN } & \text { FEB } & \text { MAR } & \text { APR } & \text { MAY } & \text { JUNE } & \text { JULY } & \text { AUG } & \text { SEPT } & \text { OCT } & \text { NOV } & \text { DEC } \\ \text { MEAN } & 57.75 & 57.76 & 57.52 & 57.31 & 57.26 & 57.22 & 57.04 & 57.29 & 57.75 & 58.56 & 59.28 & 59.80 \\ \text { LOW } & 57.98 & 57.90 & 57.75 & 57.43 & 57.33 & 57.31 & 57.11 & 57.48 & 58.19 & 58.86 & 59.62 & 60.10 \\ \text { HIGH } & 57.54 & 57.63 & 57.18 & 57.20 & 57.14 & 57.04 & 56.98 & 57.13 & 57.50 & 58.24 & 58.90 & 59.55 \\ \text { CAL YR } & 1993 & & \text { MEAN } & 57.88 & & \text { HIGH } & 56.98 & & \text { LOW } & 60.10 & & \end{array}$

Figure 78.--Water level in observation well 11K005, Dougherty County. 
315731083542301 Local number, 14P014.

LOCATION.--Lat 31 $57^{\prime} 31^{\prime \prime}$, long 8354'23", Hydrologic Unit 03130006.

Owner: Georgia Geologic Survey, Veterans Memorial Park test well 1.

INSTRUMENTATION.--Digital recorder.

AQUIFER.--Clayton.

WELL CHARACTERISTICS.--Drilled observation well, diameter 6 in., depth $550 \mathrm{ft}$ cased to $500 \mathrm{ft}$, open hole.

DATUM.--Altitude of land-surface datum is $252 \mathrm{ft}$.

REMARKS.--Well pumped May 20, 1982. Borehole geophysical survey conducted February 22, 1982.

PERIOD OF RECORD.--August 1984 to current year.

EXTREMES FOR PERIOD OF RECORD.--Highest water level, $37.16 \mathrm{ft}$ below land-surface datum, September 2, 1984; lowest,

$49.26 \mathrm{ft}$ below land-surface datum, November 29, 1988.

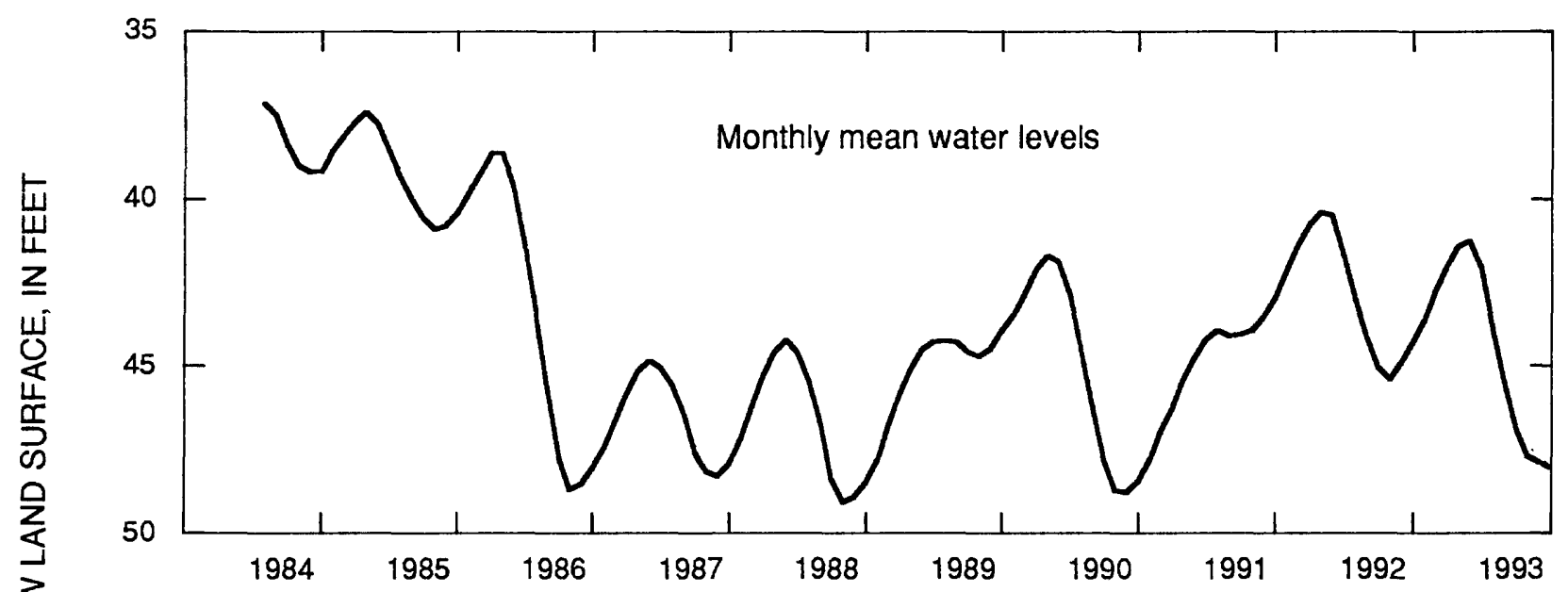

岃

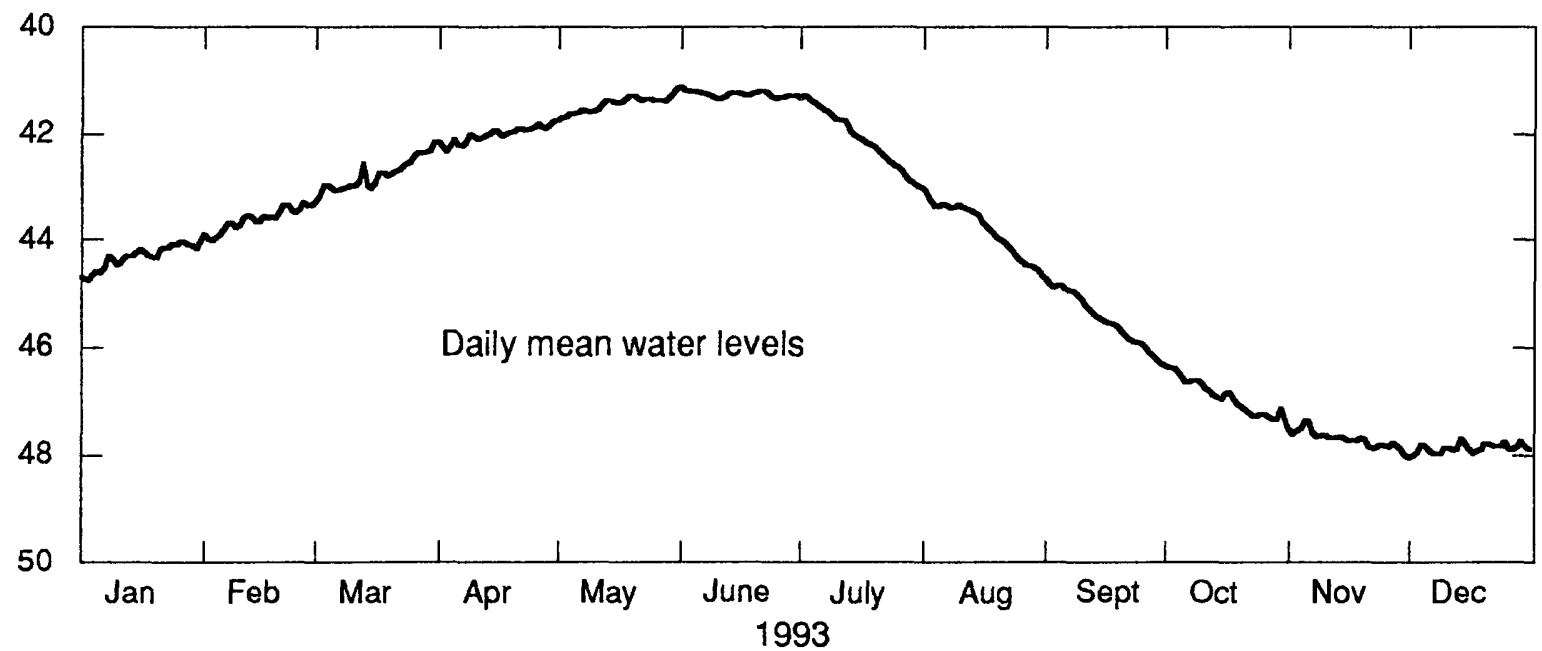

$\begin{array}{lcccccccccccc}1993 & \text { JAN } & \text { FEB } & \text { MAR } & \text { APR } & \text { MAY } & \text { JUNE } & \text { JULY } & \text { AUG } & \text { SEPT } & \text { OCT } & \text { NOV } & \text { DEC } \\ \text { MEAN } & 44.32 & 43.62 & 42.78 & 42.01 & 41.44 & 41.25 & 42.08 & 43.79 & 45.46 & 46.91 & 47.70 & 47.88 \\ \text { LOW } & 44.76 & 44.03 & 43.19 & 42.33 & 41.70 & 41.34 & 43.00 & 44.64 & 46.29 & 47.37 & 48.00 & 48.02 \\ \text { HIGH } & 44.04 & 43.30 & 42.15 & 41.75 & 41.15 & 41.18 & 41.28 & 43.11 & 44.82 & 46.37 & 47.36 & 47.69 \\ \text { CAL YR } & 1993 & & \text { MEAN } & 44.11 & & \text { HIGH } & 41.12 & & \text { LOW } & 48.06 & & \end{array}$

Figure 79.--Water level in observation well 14P014, Crisp County. 


\section{Cretaceous Aquifers and Aquifer Systems}

Water levels in Cretaceous aquifers and aquifer systems were monitored in 15 wells in 1993; data from seven of these wells (fig. 80) are summarized in figures 81-87. The Cretaceous aquifers and aquifer systems include the Providence aquifer in southwestern Georgia and the Dublin, the Midville, and the Dublin-Midville aquifer systems in the northeastern part of the Coastal Plain. Water levels in these aquifers and aquifer systems are influenced by variations in precipitation and pumping.

In Chattahoochee County near Columbus, the annual mean water level in well 06S001 (fig. 81) was about $0.8 \mathrm{ft}$ lower in 1993 than in 1992. A record low daily mean water level was recorded in the well in October that was about $2.6 \mathrm{ft}$ lower than the previous record low. 

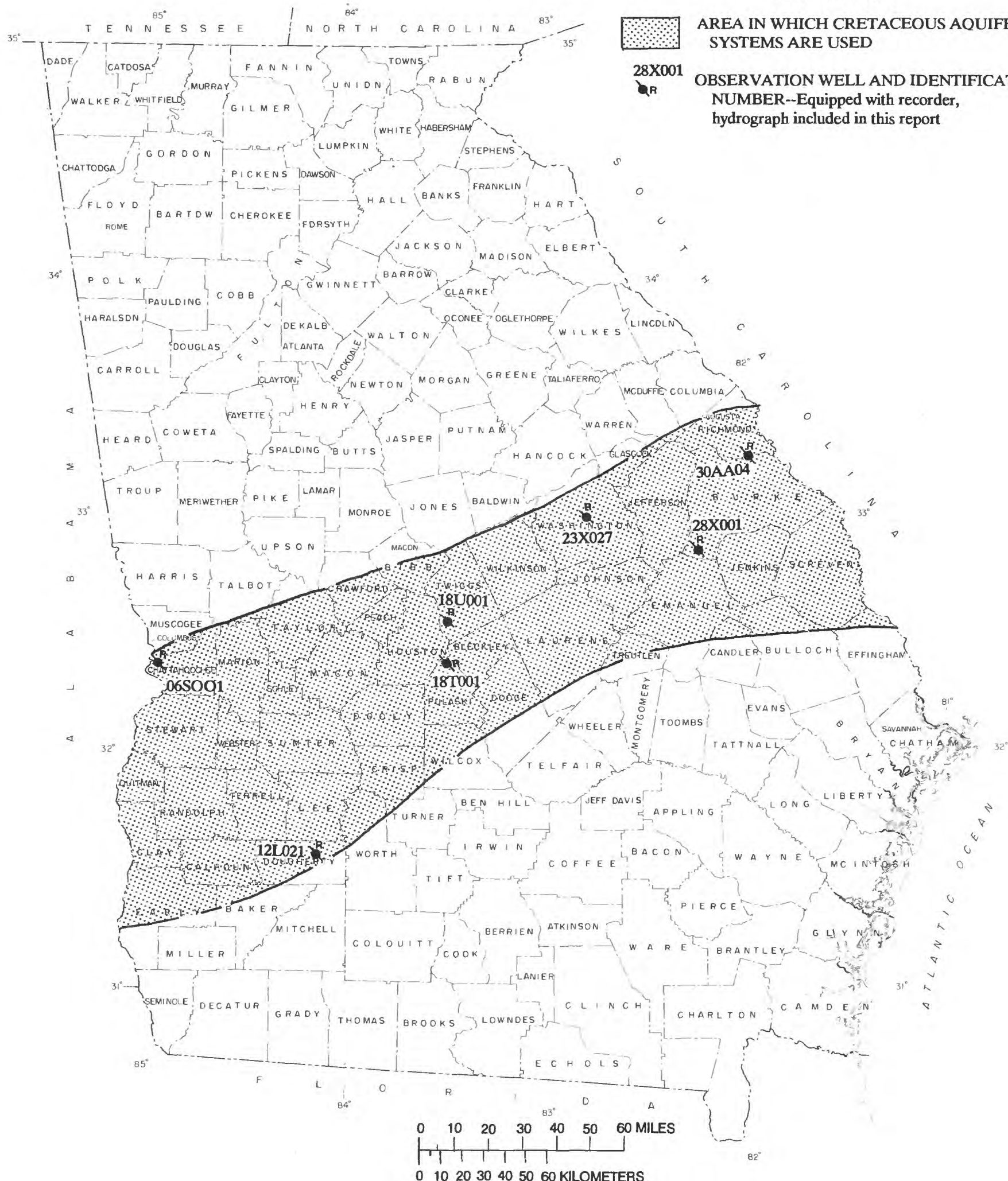

Figure 80.--Locations of observation wells completed in Cretaceous aquifers and aquifer systems. 
322036084590301 Local number, 06 S001.

LOCATION.--Lat $32^{\circ} 20^{\prime} 31^{\prime \prime}$, long $84^{\circ} 59^{\prime} 10^{\prime \prime}$, Hydrologic Unit 03130003.

Owner: U.S. Army, Fort Benning.

INSTRUMENTATION.--Digital recorder.

AQUIFER.-- Cretaceous age formations (Blufftown, Eutaw, and Tuscaloosa Formations).

WELL CHARACTERISTICS.--Drilled unused supply well, diameter 12 in., depth $568 \mathrm{ft}$, screened intervals 215-220 ft, $230-235 \mathrm{ft}, 280-290 \mathrm{ft}$, and $540-550 \mathrm{ft}$.

DATUM.--Altitude of land-surface datum is $255 \mathrm{ft}$.

REMARKS.--Well pumped and redeveloped August 7, 1989. Well pumped and sampled by Georgia Geologic Survey, April 28,1992.

PERIOD OF RECORD.--August 1953 to current year.

EXTREMES FOR PERIOD OF RECORD.--Highest water level, $0.37 \mathrm{ft}$ below land-surface datum, April 10, 1964; lowest, $36.70 \mathrm{ft}$ below land-surface datum, October 23-24, 1993.
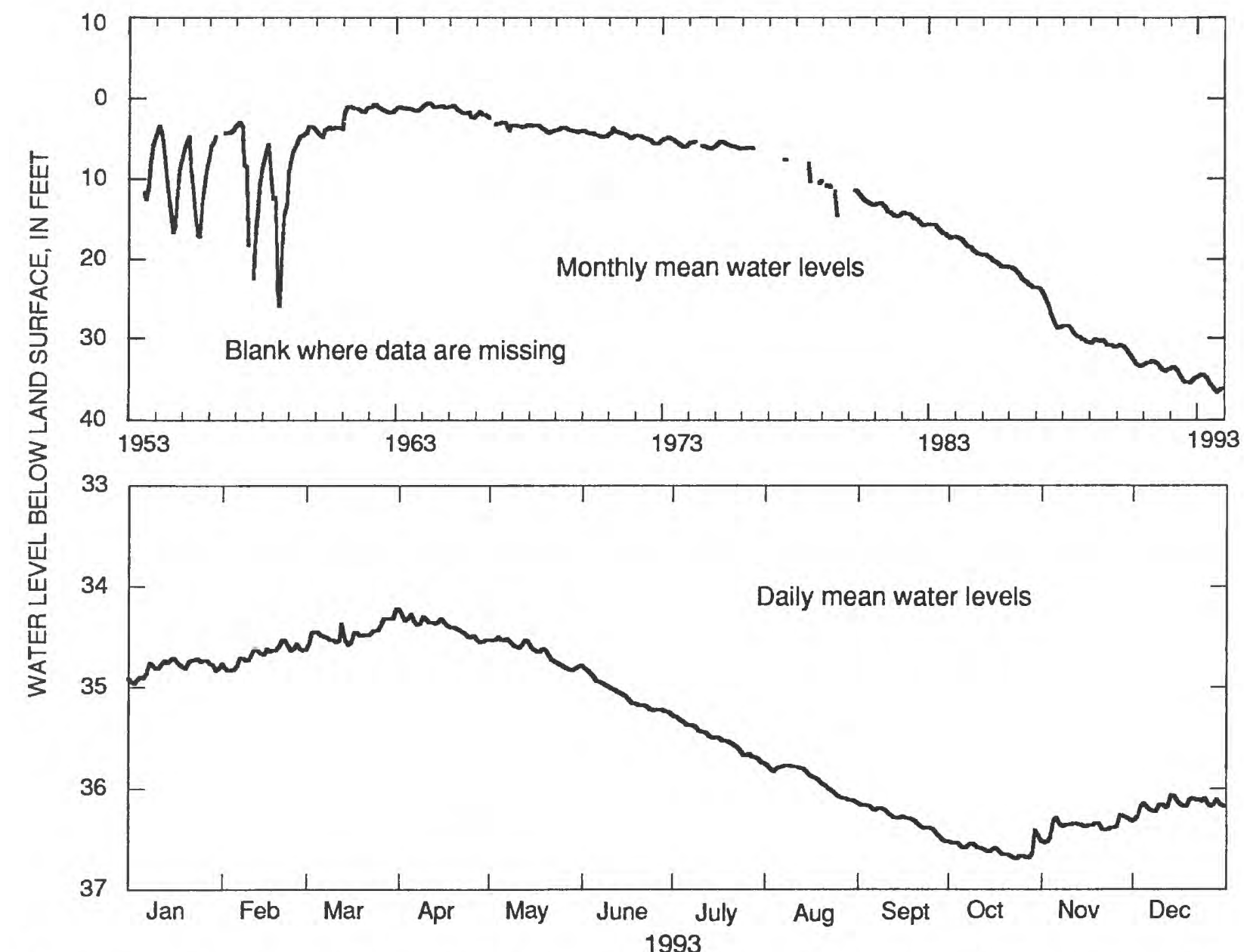

$\begin{array}{lcccccccccccc}1993 & \text { JAN } & \text { FEB } & \text { MAR } & \text { APR } & \text { MAY } & \text { JUNE } & \text { JULY } & \text { AUG } & \text { SEPT } & \text { OCT } & \text { NOV } & \text { DEC } \\ \text { MEAN } & 34.80 & 34.68 & 34.46 & 34.40 & 34.65 & 35.07 & 35.50 & 35.91 & 36.30 & 36.61 & 36.38 & 36.17 \\ \text { LOW } & 34.97 & 34.84 & 34.58 & 34.56 & 34.84 & 35.25 & 35.74 & 36.13 & 36.53 & 36.70 & 36.54 & 36.31 \\ \text { HIGH } & 34.71 & 34.53 & 34.23 & 34.28 & 34.50 & 34.82 & 35.29 & 35.77 & 36.17 & 36.42 & 36.27 & 36.07 \\ \text { CAL YR } & 1993 & & \text { MEAN } & 35.41 & & \text { HIGH } & 34.22 & & \text { LOW } & 36.70 & & \end{array}$

Figure 81.--Water level in observation well 065001, Chattahoochee County. 


\section{Providence aquifer}

The water level in the Providence aquifer in the Albany area (fig. 80) was monitored in one well in 1993, as shown in figure 82. Water levels in the aquifer are influenced by variations in precipitation and pumping (Clarke and others, 1983). In 1993, the annual mean water level in well 12L021 (fig. 82) was about $3.0 \mathrm{ft}$ lower than in 1992. 
313534084103003 Local number, $12 \mathrm{~L} 021$.

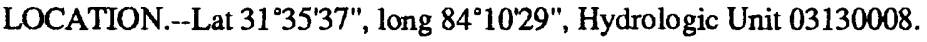

Owner: U.S. Geological Survey, test well 10.

INSTRUMENTATION.--Electronic data recorder.

AQUIFER.--Providence.

WELL CHARACTERISTICS.--Drilled observation well, diameter $6 \mathrm{in}$., depth $834 \mathrm{ft}$, cased to $810 \mathrm{ft}$, screen to $830 \mathrm{ft}$.

DATUM.-Altitude of land-surface datum is $198 \mathrm{ft}$.

REMARKS.--Borehole geophysical survey conducted October 26, 1978. Well pumped and sampled by Georgia Geologic

Survey, October 24, 1989. Water levels for periods, February 26 to March 2, 4-11, 23 to April 20, and September 3-6,

were estimated.

PERIOD OF RECORD.--December 1978 to current year.

EXTREMES FOR PERIOD OF RECORD.--Highest water level, $101.59 \mathrm{ft}$ below land-surface datum, April 26, 1984; lowest,

$156.36 \mathrm{ft}$ below land-surface datum, July 26, 1986.
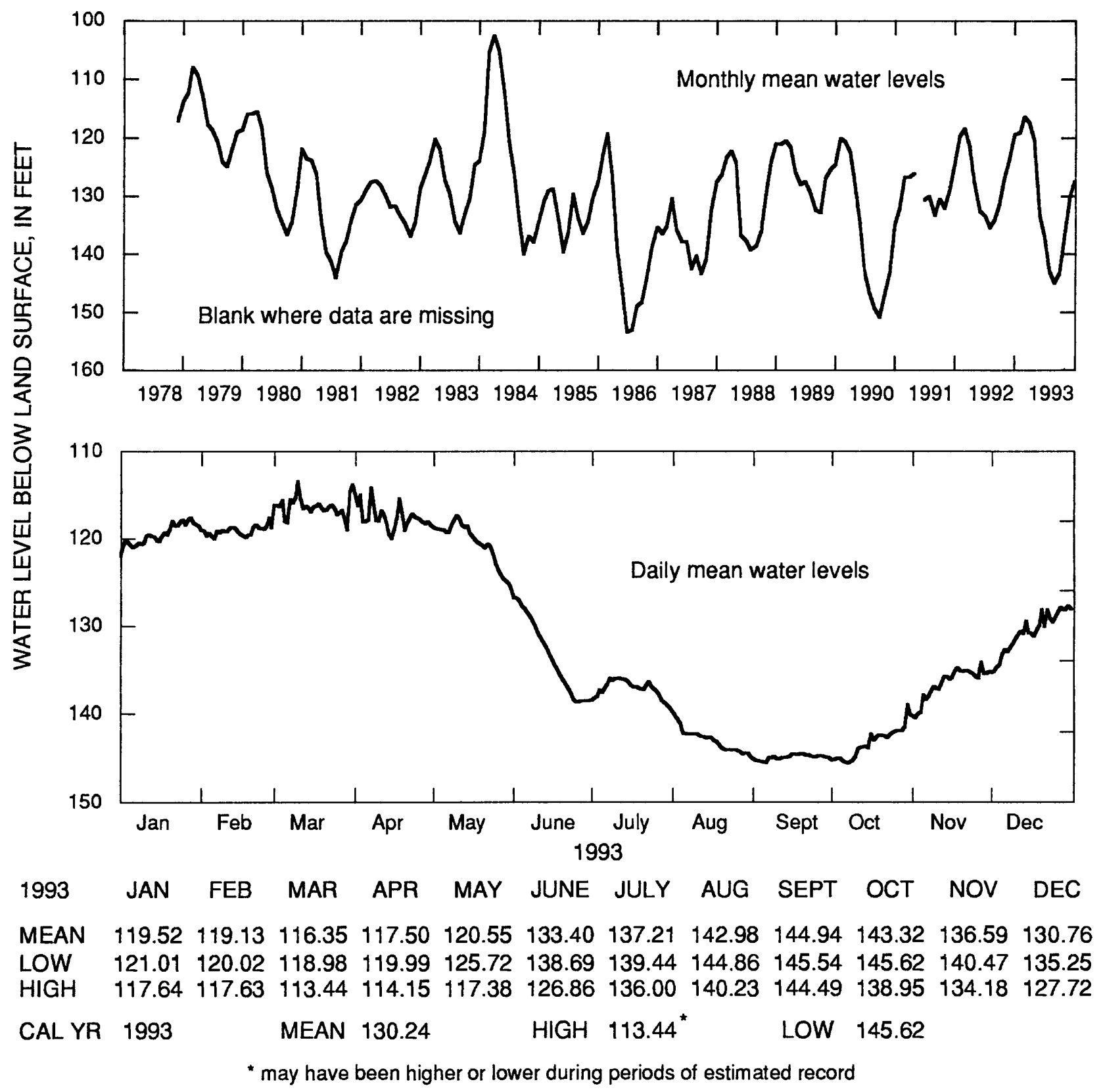

Figure 82.--Water level in observation well 12L021, Dougherty County. 


\section{Dublin aquifer system}

The water level was monitored in four wells in the Dublin aquifer system in 1993; data from one of these wells (fig. 80) are summarized in figure 83. In the eastern Houston County and western Twiggs County area, water levels in wells tapping the aquifer are affected by precipitation and pumping (Clarke and others, 1985). The annual mean water level in well 18U001 (fig. 83) was about $0.4 \mathrm{ft}$ higher in 1993 than in 1992. 
323302083263401 Local number, $18 \mathrm{U} 001$.

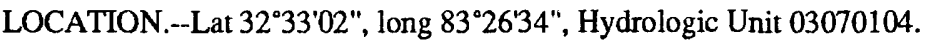

Owner: Georgia Kraft, U.S. Geological Survey, test well 3.

INSTRUMENTATION.--Digital recorder.

AQUIFER.--Dublin aquifer system.

WELL CHARACTERISTICS.--Drilled observation well, diameter 6 in., depth $616 \mathrm{ft}$, cased to $586 \mathrm{ft}$, screen to $616 \mathrm{ft}$.

DATUM.--Altitude of land-surface datum is $442 \mathrm{ft}$.

REMARKS.--Water-quality analysis June 10, 1975.

PERIOD OF RECORD.--July 1975 to current year.

EXTREMES FOR PERIOD OF RECORD.--Highest water level, $162.0 \mathrm{ft}$ below land-surface datum, April 4, 1977; lowest,

$166.44 \mathrm{ft}$ below land-surface datum, October 3, 1990.
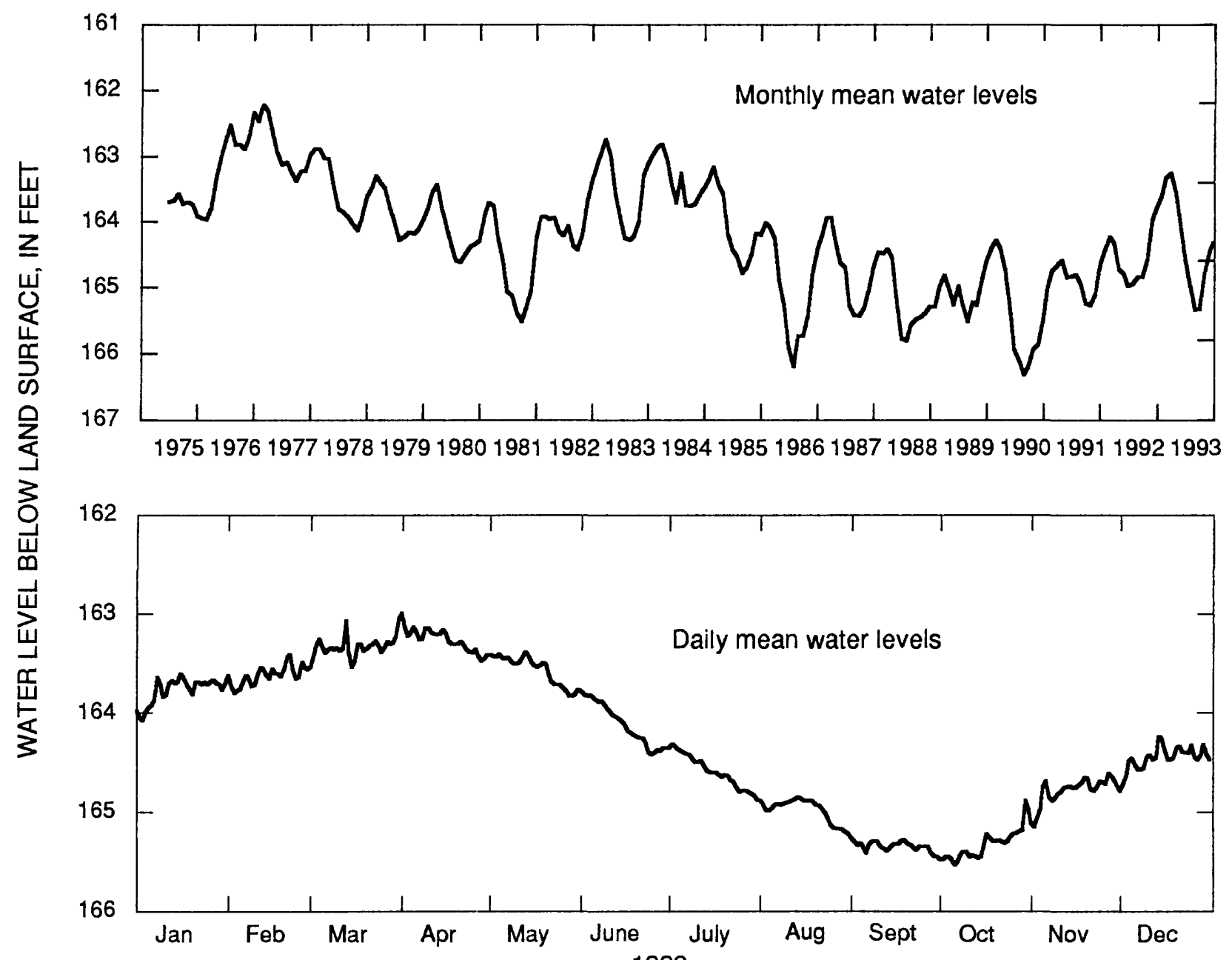

1993 JAN FEB MAR APR MAY JUNE JULY AUG SEPT OCT NOV DEC

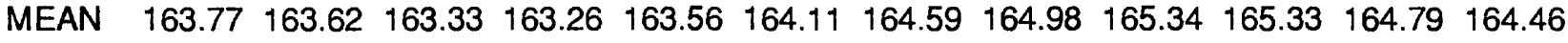

LOW $\quad \begin{array}{lllllllllllll}164.08 & 163.80 & 163.53 & 163.47 & 163.83 & 164.43 & 164.88 & 165.22 & 165.45 & 165.53 & 165.15 & 164.72\end{array}$

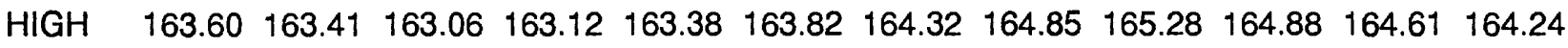

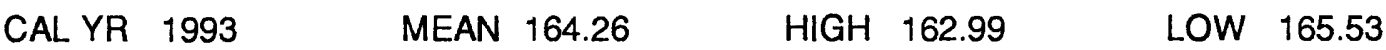

Figure 83.--Water level in observation well 18U001, Twiggs County. 


\section{Midville aquifer system}

The water level was monitored in seven wells in east-central Georgia in 1993 (fig. 80). Data from two of these wells, 18T001 and 28X001, are summarized in figures 84 and 85 . The water level in the Midville aquifer system is affected mainly by regional pumping (Clarke and others, 1985). In 1993, the annual mean water level in these wells ranged from about the same to $0.2 \mathrm{ft}$ lower than in 1992 , respectively. 
322245083290101 Local number, $18 \mathrm{~T} 001$.

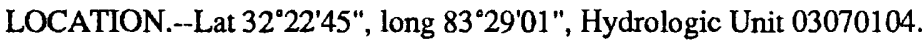

Owner: U.S. Geological Survey, Arrowhead test well 1.

INSTRUMENTATION.--Digital recorder.

AQUIFER.--Midville aquifer system.

WELL CHARACTERISTICS.--Drilled observation well, diameter 6 in., depth $1,555 \mathrm{ft}$, cased to $970 \mathrm{ft}$, screened intervals,

970-980 ft, 1,110-1,130 ft, and 1,270-1,280 ft.

DATUM.--Altitude of land-surface datum is $334 \mathrm{ft}$.

REMARKS.--Borehole geophysical survey conducted January 28 and April 15, 1981. Water-quality analysis May 12, 1981.

PERIOD OF RECORD.-- June 1981 to current year.

EXTREMES FOR PERIOD OF RECORD.--Highest water level, $55.48 \mathrm{ft}$ below land-surface datum, April 12, 1983; lowest, $59.52 \mathrm{ft}$ below land-surface datum, October 7-8, 1990.

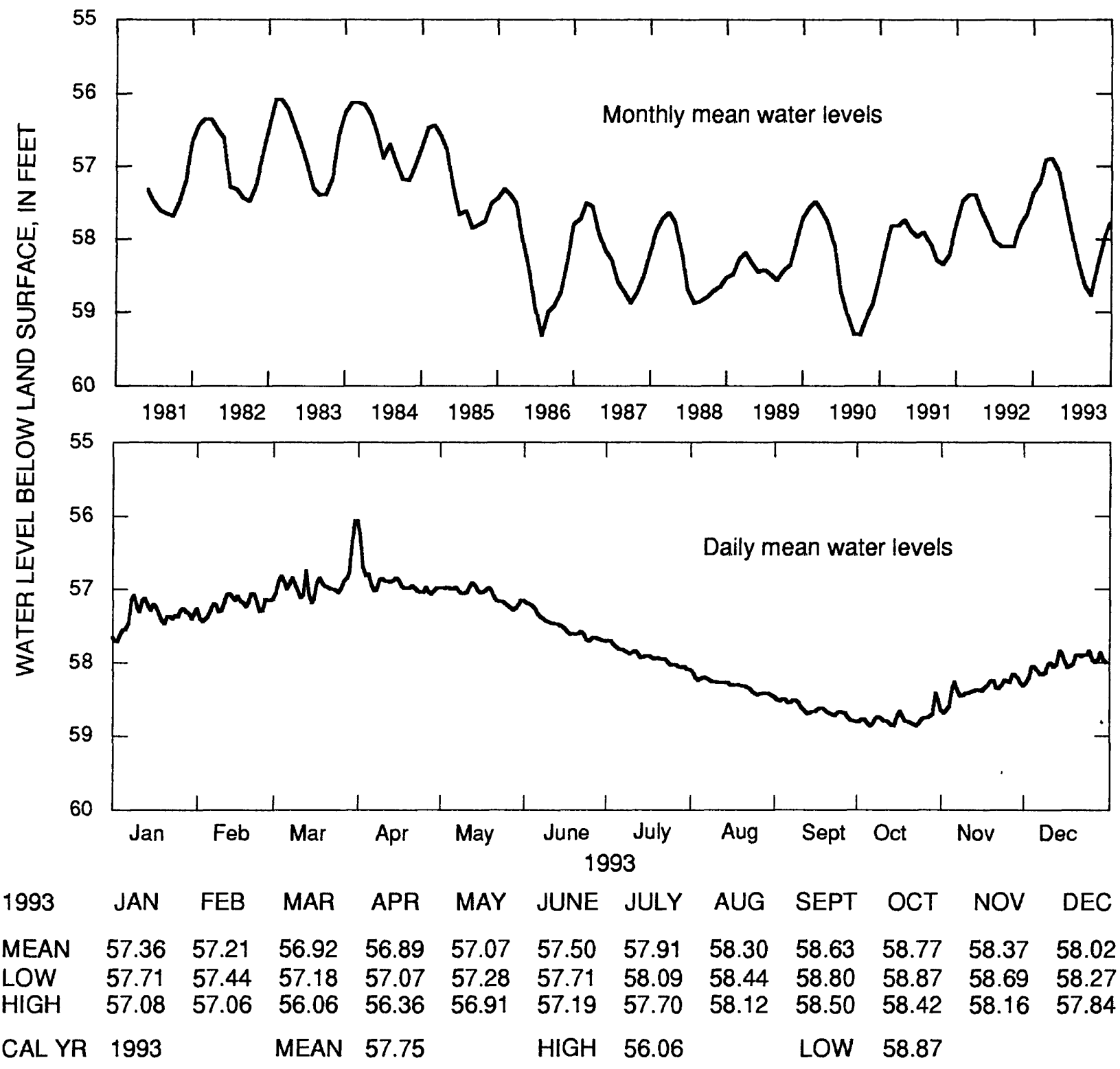

Figure 84.--Water level in observation well 18T001, Pulaski County. 
325232082131501 Local number, $28 \times 001$.

LOCATION.--Lat 32'52'32", long 82¹3'15", Hydrologic Unit 03060201.

Owner: U.S. Geological Survey, Midville Experiment Station 1.

INSTRUMENTATION.--Digital recorder.

AQUIFER.--Midville aquifer system.

WELL CHARACTERISTICS.--Drilled observation well, diameter 4 in., depth 1,045 ft, cased to 1,025 ft, screen to 1,045 ft. DATUM.--Altitude of land-surface datum is $269 \mathrm{ft}$.

REMARKS.--Borehole geophysical survey conducted March 8 and April 22, 1980. Water-quality analyses May 23, 1980. PERIOD OF RECORD.--June 1980 to current year.

EXTREMES FOR PERIOD OF RECORD.--Highest water level, $49.07 \mathrm{ft}$ below land-surface datum, June 4, 1980; lowest, $59.91 \mathrm{ft}$ below land-surface datum, November 30, 1990.
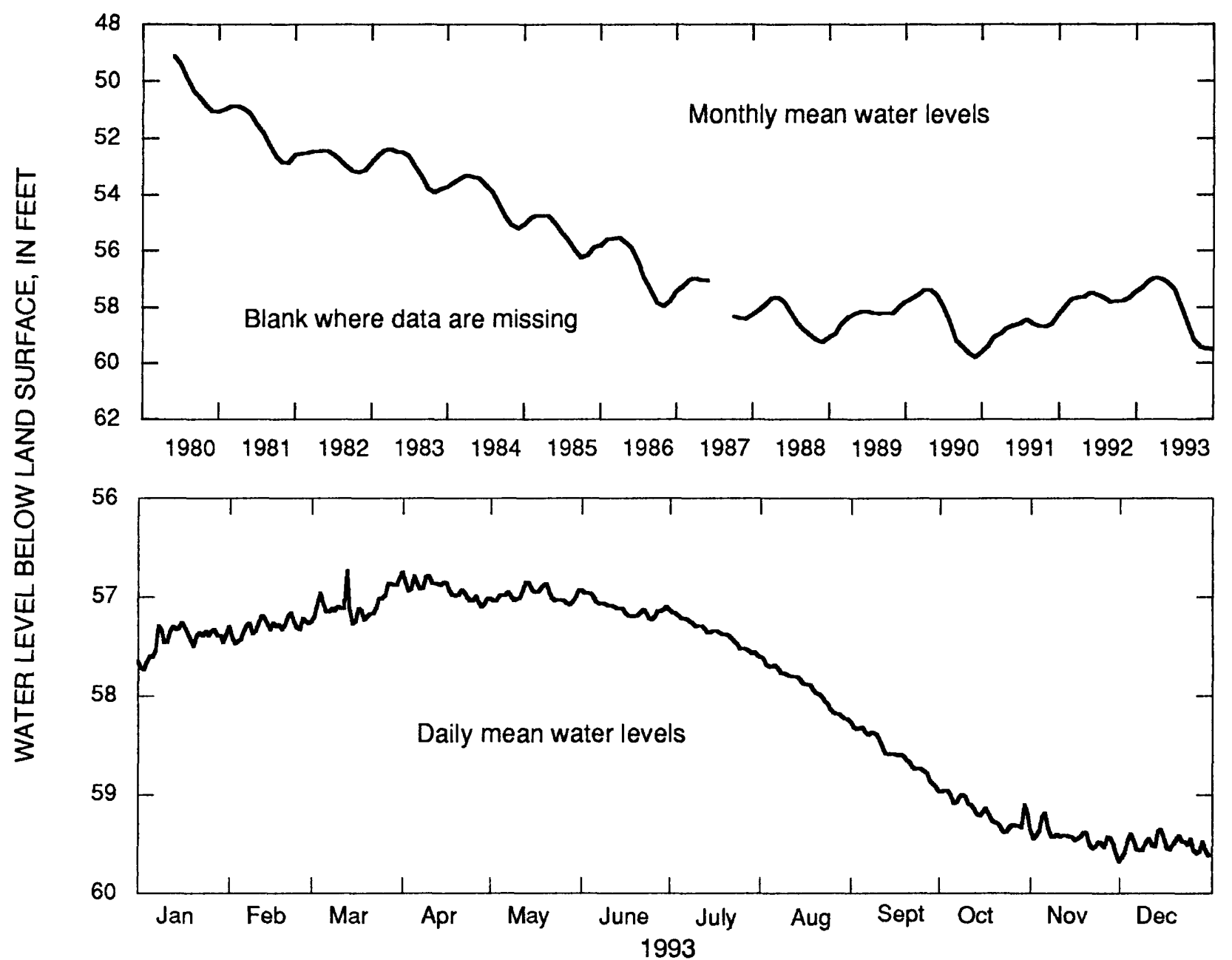

$\begin{array}{lcccccccccccc}1993 & \text { JAN } & \text { FEB } & \text { MAR } & \text { APR } & \text { MAY } & \text { JUNE } & \text { JULY } & \text { AUG } & \text { SEPT } & \text { OCT } & \text { NOV } & \text { DEC } \\ \text { MEAN } & 57.43 & 57.30 & 57.07 & 56.93 & 56.98 & 57.11 & 57.36 & 57.91 & 58.58 & 59.17 & 59.43 & 59.52 \\ \text { LOW } & 57.74 & 57.47 & 57.27 & 57.10 & 57.08 & 57.23 & 57.60 & 58.23 & 58.93 & 59.39 & 59.60 & 59.64 \\ \text { HIGH } & 57.26 & 57.16 & 56.74 & 56.79 & 56.85 & 56.96 & 57.16 & 57.62 & 58.32 & 58.96 & 59.19 & 59.36 \\ \text { CAL YR } & 1993 & & \text { MEAN } & 57.90 & & \text { HIGH } & 56.74 & & \text { LOW } & 59.68 & & \end{array}$

Figure 85.--Water level in observation well 28X001, Burke County. 


\section{Dublin-Midville aquifer system}

The water level in the Dublin-Midville aquifer system (fig. 80) was monitored in two wells in 1993, and are summarized in figures 86 and 87. Water levels in wells tapping the Dublin-Midville aquifer system in Richmond County are influenced mainly by precipitation and by local pumping (Gorday, 1985, p. 28). The annual mean water level in well 30AA04 (fig. 86) near McBean in southern Richmond County, was about $0.4 \mathrm{ft}$ higher in 1993 than in 1992.

At Sandersville, Washington County, the water level in the Dublin-Midville aquifer system is influenced primarily by local pumping. During 1993, the annual mean water level in well 23 X027 (fig. 87) was about $1.8 \mathrm{ft}$ lower than in 1992. A record low daily mean water level was recorded in this well in October that was $0.6 \mathrm{ft}$ lower than the previous record low. 
331711081573701 Local number, 30AA04.

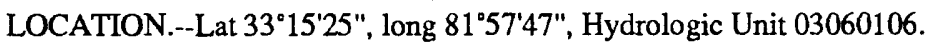

Owner: Richmond County water system, USGS McBean 2.

INSTRUMENTATION.--Digital recorder.

AQUIFER.--Dublin-Midville aquifer system.

WELL CHARACTERISTICS.--Drilled unused municipal well, diameter 6 in., depth $496 \mathrm{ft}$, cased to $174 \mathrm{ft}$, screened intervals, $174-192 \mathrm{ft}, 299-319 \mathrm{ft}, 341-372 \mathrm{ft}$, and $393-434 \mathrm{ft}$.

DATUM.--Altitude of land-surface datum is $293 \mathrm{ft}$.

REMARKS.--Borehole geophysical survey conducted October 23, 1967. Water-quality sample collected November 26, 1967. PERIOD OF RECORD.--June 1979 to current year.

EXTREMES FOR PERIOD OF RECORD.--Highest water level, $116.70 \mathrm{ft}$ below land-surface datum, May 30, 1984; lowest, $129.61 \mathrm{ft}$ below land-surface datum, August 28, 1988.

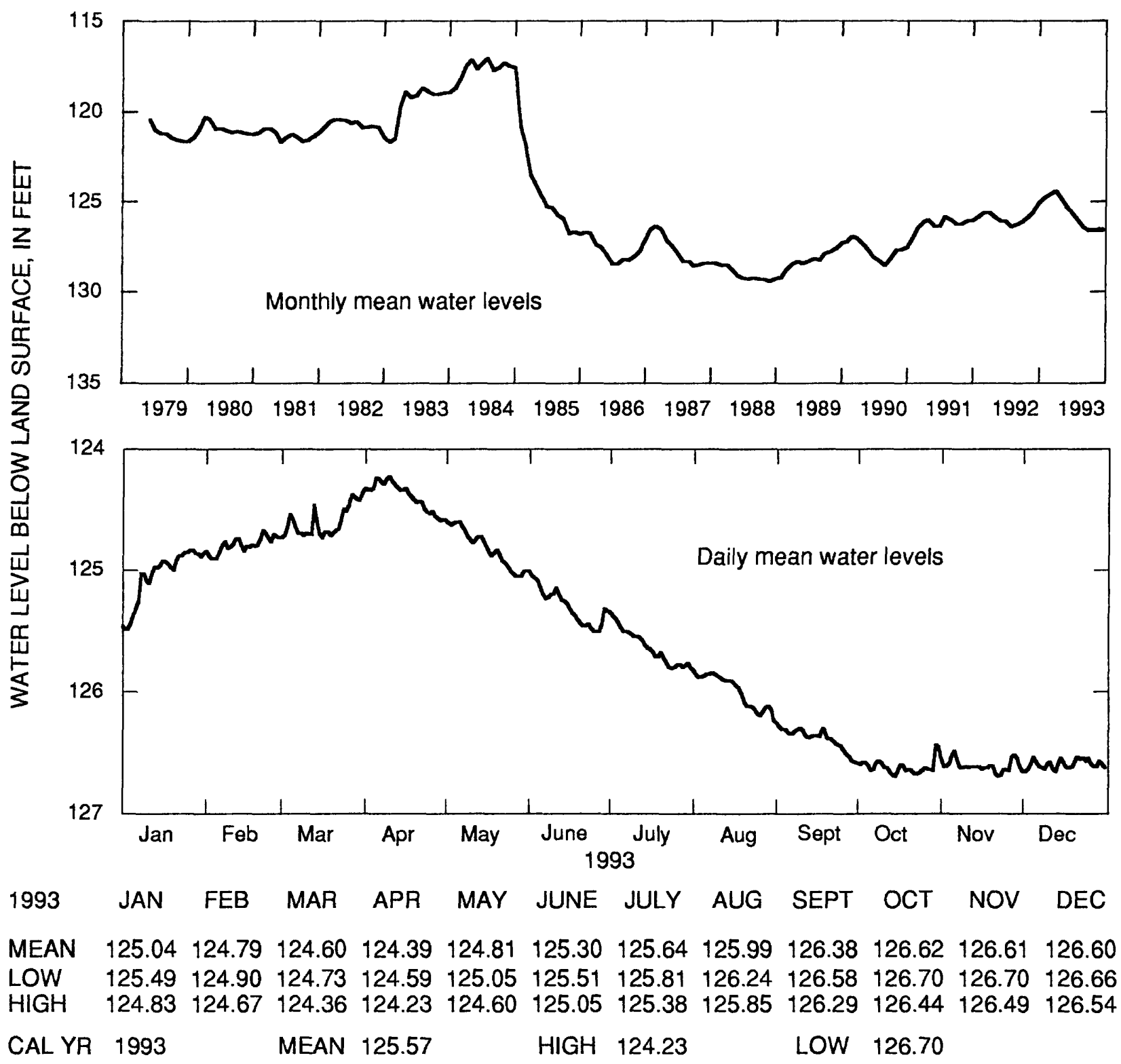

Figure 86.--Water level in observation well $30 A A 04$, Richmond County. 
325848082480901 Local number, $23 \mathrm{X} 027$.

LOCATION.--Lat 32'58'48", long 8248'08", Hydrologic Unit 03070102.

Owner: City of Sandersville, well 8.

INSTRUMENTATION.--Digital recorder.

AQUIFER.--Dublin-Midville aquifer system.

WELL CHARACTERISTICS.--Drilled unused municipal well, diameter 8 in., depth $750 \mathrm{ft}$, cased to $480 \mathrm{ft}$, screened intervals, $480-485 \mathrm{ft}, 605-610 \mathrm{ft}, 650-655 \mathrm{ft}, 695-700 \mathrm{ft}$, and $740-745 \mathrm{ft}$.

DATUM.--Altitude of land-surface datum is $450 \mathrm{ft}$.

REMARKS.--Borehole geophysical survey conducted March 14, 1985. Well sounded to $672 \mathrm{ft}$ on March 14, 1985. Lower screens probably caved.

PERIOD OF RECORD.--March 1985 to current year.

EXTREMES FOR PERIOD OF RECORD.--Highest water level, $227.68 \mathrm{ft}$ below land-surface datum, April 9, 1985; lowest, $251.51 \mathrm{ft}$ below land-surface datum, October 6, 1993.

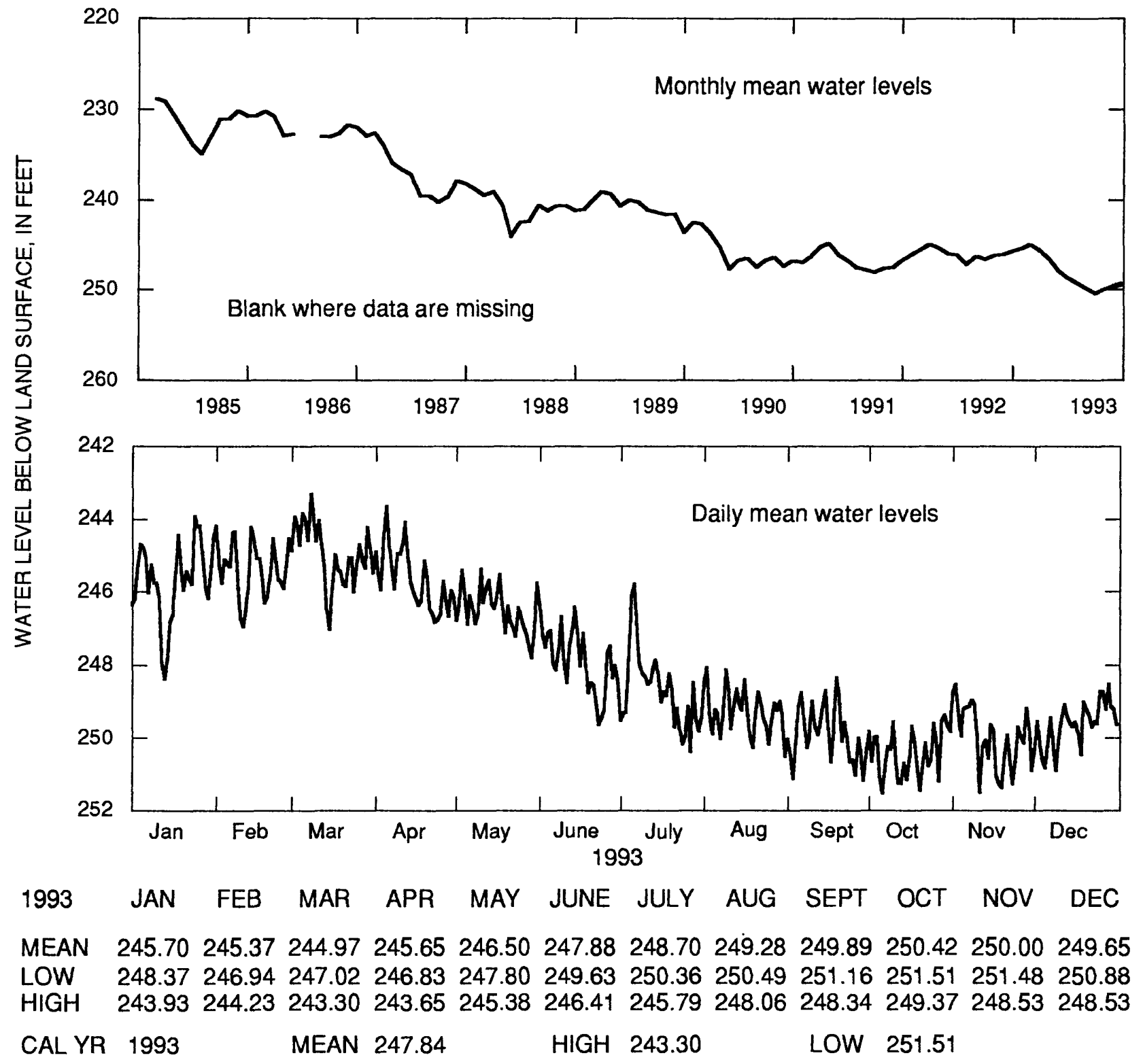

Figure 87.--Water level in observation well 23X027, Washington County. 


\section{Paleozoic Rock Aquifers}

The water level in an unconfined Paleozoic aquifer in Walker County (fig. 88) was monitored in well 03PP01 in 1993 (fig. 89). In this area, water levels in wells tapping the Paleozoic rock aquifers are affected mainly by precipitation and local pumping. The effect of precipitation on water levels in areas where thin regolith overlies aquifers having secondary openings (fractures or solution openings) is indicated in the hydrograph of daily mean water levels for well 03PP01 (fig. 89). The annual mean water level in this well was about $2.0 \mathrm{ft}$ lower in 1993 than in 1992. 


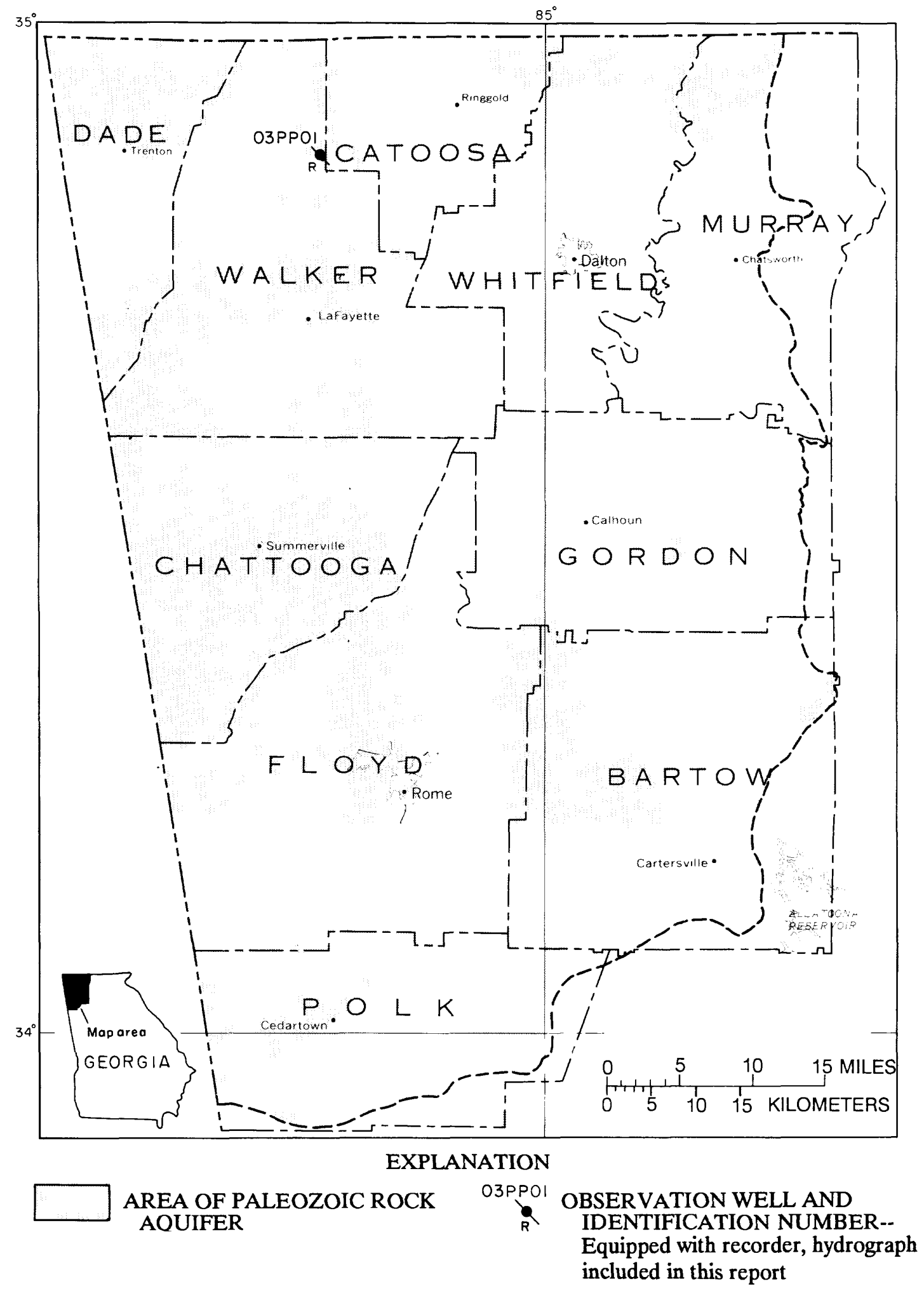

Figure 88--Location of observation well completed in the Paleozoic rock aquifer. 
345403085160001 Local number, 03PP01.

LOCATION.--Lat $34^{\circ} 54^{\prime} 08^{\prime \prime}$, long $85^{\circ} 16^{\prime} 00^{\prime \prime}$, Hydrologic Unit 06020001.

Owner: National Park Service, Chickamauga Battlefield Park.

INSTRUMENTATION.--Digital recorder.

AQUIFER.--Paleozoic Rock (Chickamauga Limestone).

WELL CHARACTERISTICS.--Cable-tooled, observation well, diameter 8 in., depth $72 \mathrm{ft}$, cased to $11 \mathrm{ft}$, open hole.

DATUM.--Altitude of land-surface datum is $730 \mathrm{ft}$.

REMARKS.--Well sounded October 18, 1977.

PERIOD OF RECORD.--November 1977 to current year.

EXTREMES FOR PERIOD OF RECORD.--Highest water level, $1.97 \mathrm{ft}$ below land-surface datum, March 9, 1978; lowest,

$21.70 \mathrm{ft}$ below land-surface datum, August 5, 1978.

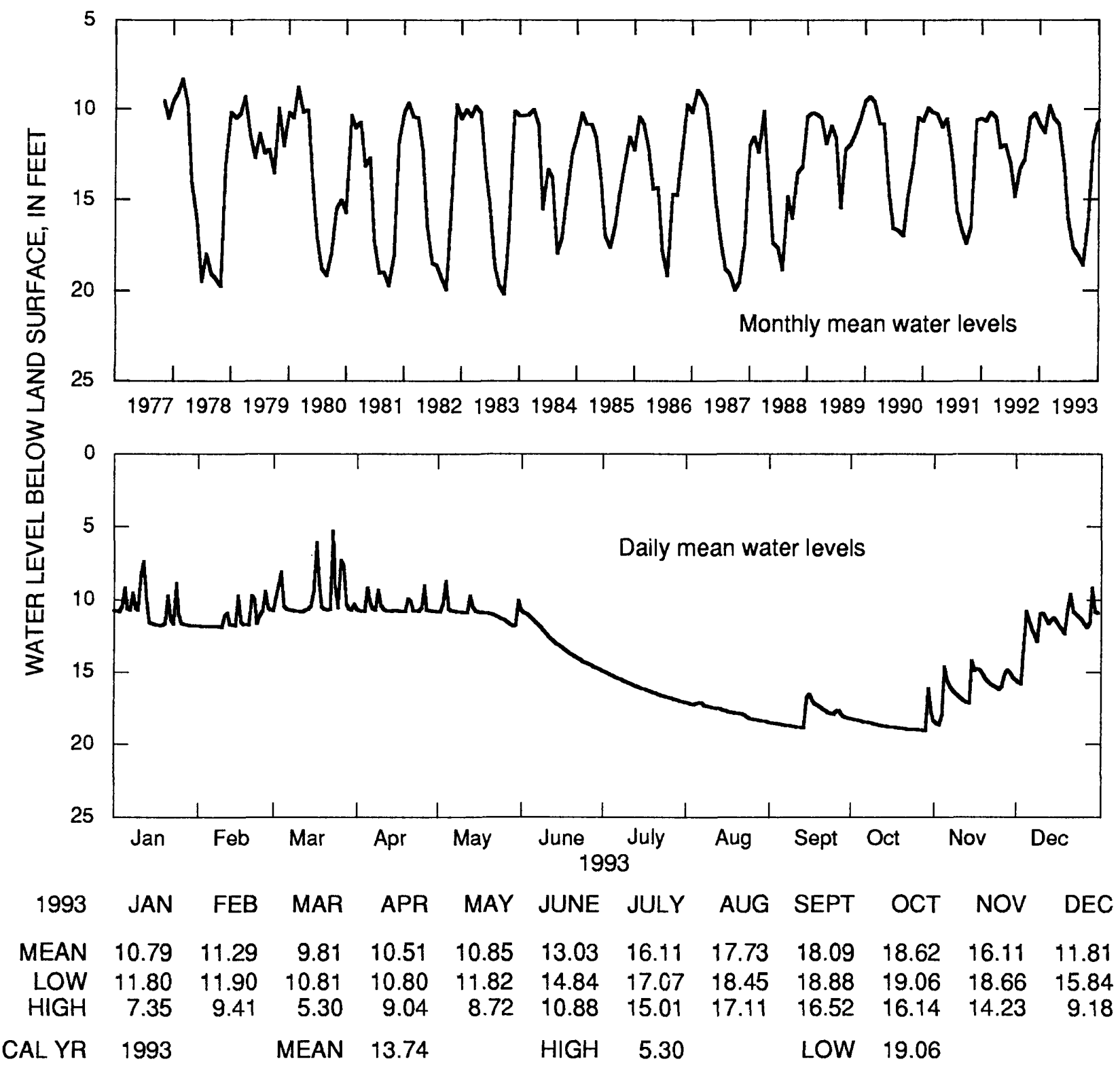

Figure 89.--Water level in observation well 03PP01, Walker County. 


\section{Crystalline-Rock Aquifers}

Water levels in the crystalline-rock aquifers (fig. 90) were monitored in eight wells in 1993, five of which are summarized in figures 91-95. Water levels in wells tapping the crystalline-rock aquifers are affected mainly by precipitation and evapotranspiration, and locally by pumping. Precipitation can cause rapid rises in water levels in areas where thin regolith overlies aquifers having secondary openings, and the effect is illustrated in the hydrograph for well 11FF04 (fig. 93). The annual mean water levels in these wells (figs. 91-95) ranged from $0.6 \mathrm{ft}$ lower to $3.0 \mathrm{ft}$ higher in 1993 than in 1992. A record low daily mean water level was recorded in well 11FF04 (fig. 93) in October that was $0.1 \mathrm{ft}$ lower than the previous record low. A record high daily mean water level was recorded in well 21BB04 (fig. 94) in March that was $0.7 \mathrm{ft}$ higher than the previous record high. 


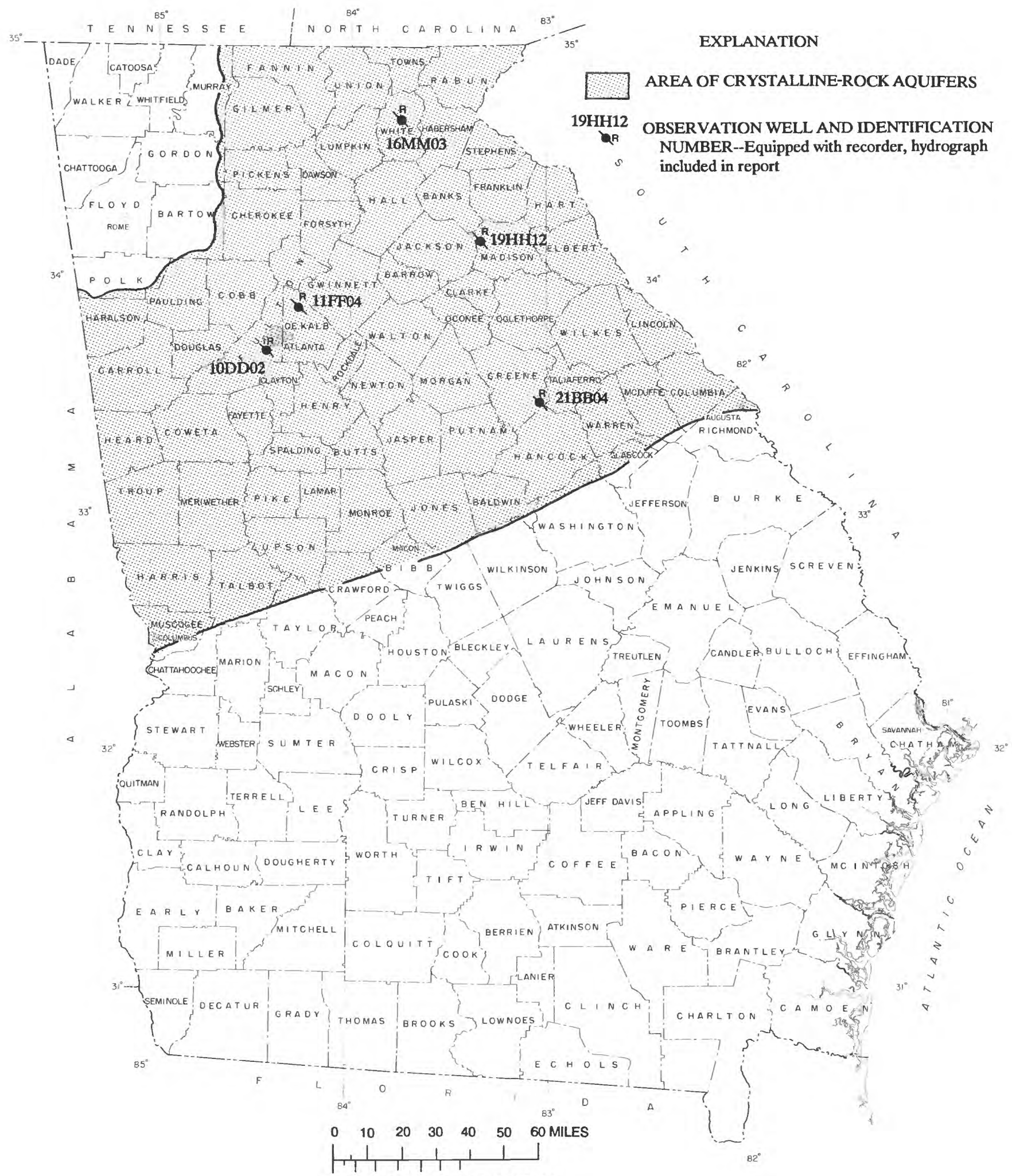

O 102030405060 KILOMETERS

Figure 90.--Locations of observation wells completed in crystalline-rock aquifers. 
334207084254801 Local number, 10DD02.

LOCATION.--Lat $33^{\circ} 42^{\prime} 07^{\prime \prime}$, long 84²5'48", Hydrologic Unit 03130002.

Owner: U.S. Army, Fort McPherson.

INSTRUMENTATION.--Digital recorder.

AQUIFER.--Crystalline rock (Biotite gneiss).

WELL CHARACTERISTICS.--Drilled, unused supply well, diameter $12 \mathrm{in}$., depth $338 \mathrm{ft}$, cased to $41 \mathrm{ft}$, open hole.

DATUM.--Altitude of land-surface datum is $1,013 \mathrm{ft}$.

REMARKS.--Well pumped and sounded February 14, 1976, to a depth of $338 \mathrm{ft}$. Well pumped and sampled by Georgia

Geologic Survey, September 22, 1992. Borehole geophysical survey conducted November 19, 1974.

PERIOD OF RECORD.--November 1973 to current year.

EXTREMES FOR PERIOD OF RECORD.--Highest water level, $0.10 \mathrm{ft}$ below land-surface datum, March 30, 1980; lowest, $10.95 \mathrm{ft}$ below land-surface datum, September 2, 1988.

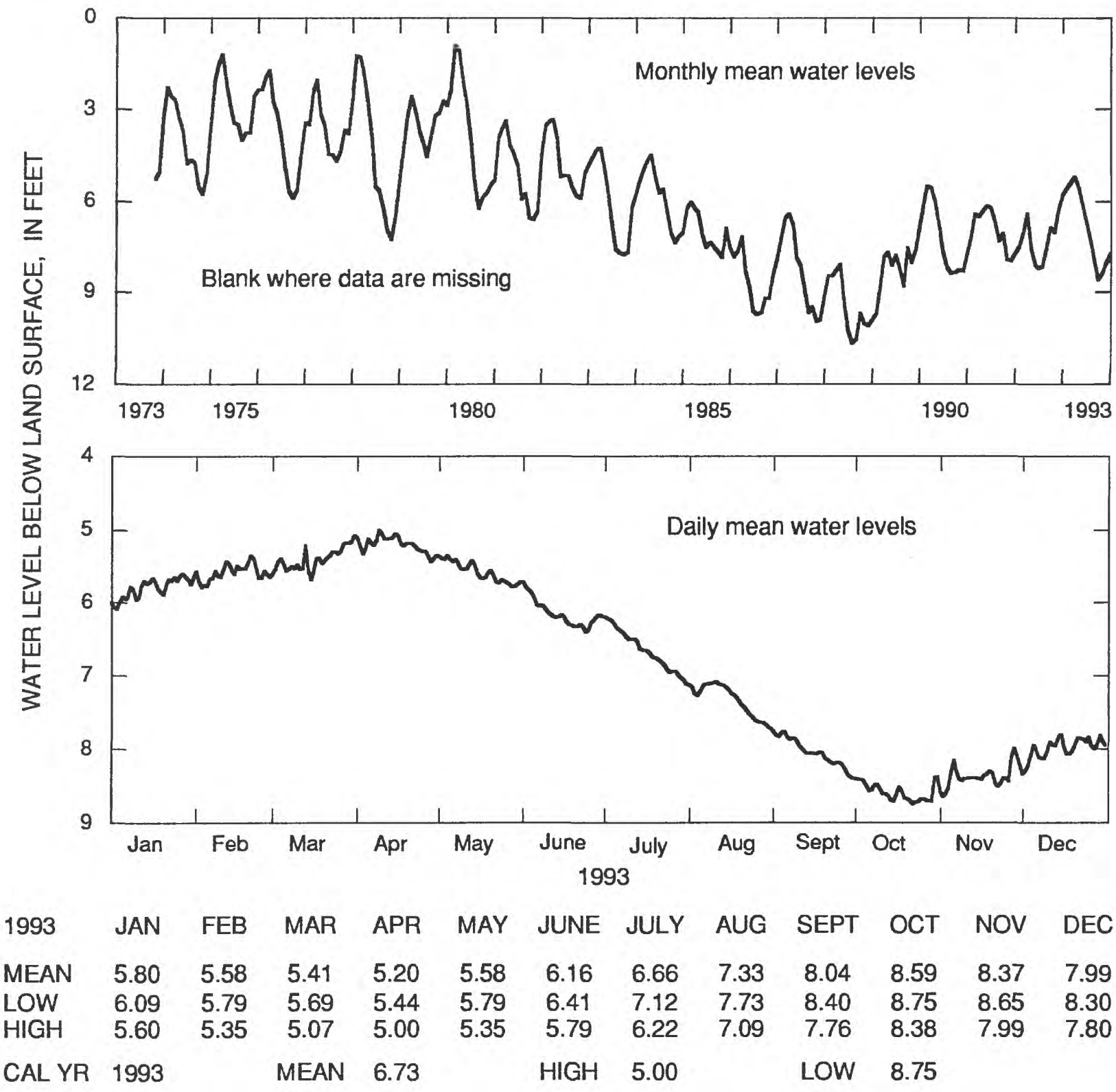

Figure 91.--Water level in observation well 10DD02, Fulton County. 
341020083201701 Local number, $19 \mathrm{HH} 12$.

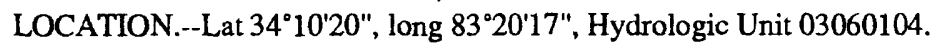

Owner: Meadowlake Estates.

INSTRUMENTATION.--Digital recorder.

AQUIFER.--Crystalline rock.

WELL CHARACTERISTICS.--Drilled, unused supply well, diameter 6 in., depth $185 \mathrm{ft}$, cased to $50 \mathrm{ft}$, open hole.

DATUM.--Altitude of land-surface datum is $800 \mathrm{ft}$.

REMARKS.--Pump test conducted April 4-5, 1984. Borehole geophysical survey conducted October 31, 1983 and

November 16, 1983. Water levels for period of missing record, January 25 to February 17, were estimated.

PERIOD OF RECORD.--October 1983 to current year.

EXTREMES FOR PERIOD OF RECORD.--Highest water level, $6.69 \mathrm{ft}$ below land-surface datum, April 14, 1984; lowest,

$15.56 \mathrm{ft}$ below land-surface datum, September 2-3, 1988.
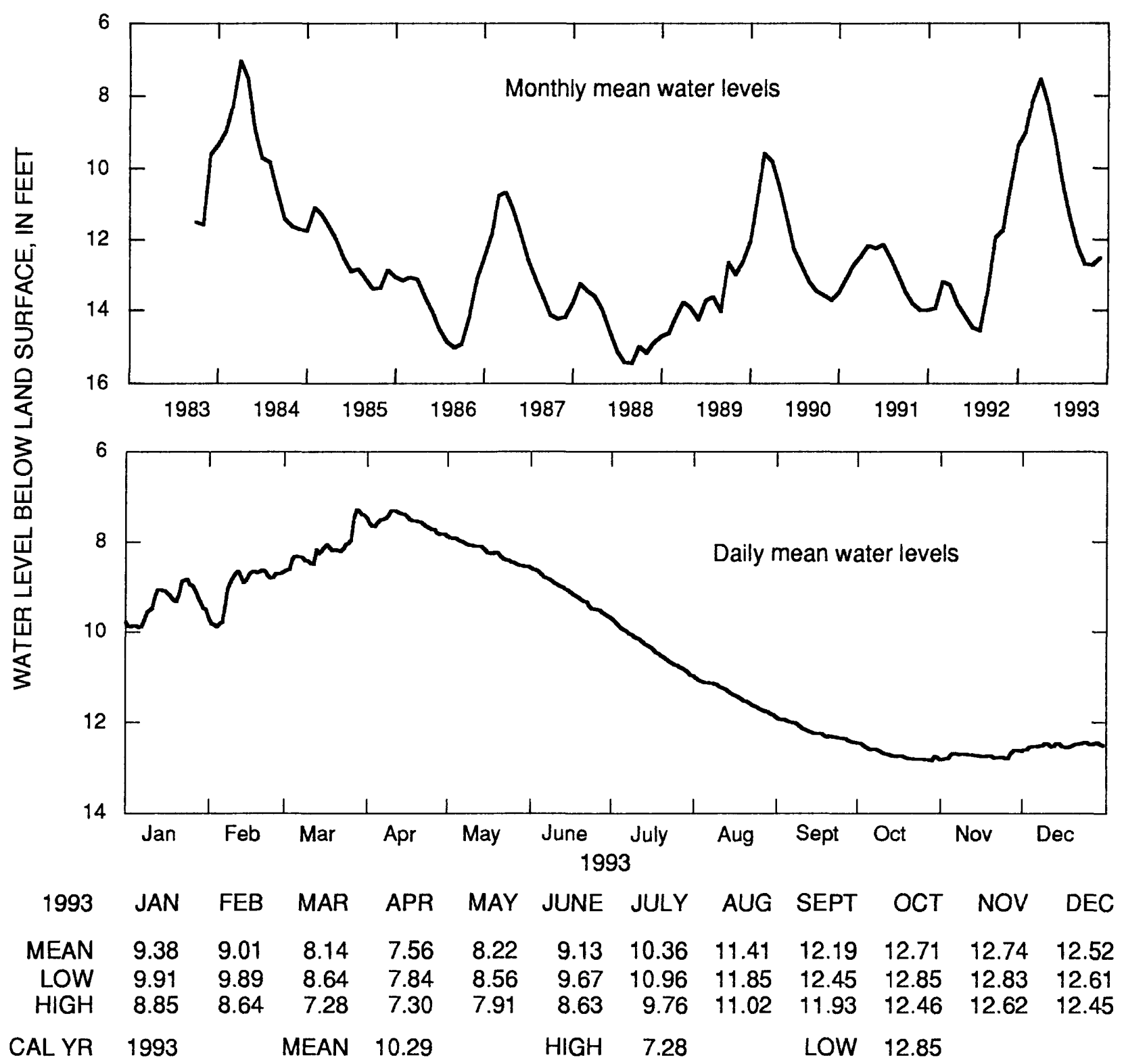

Figure 92.--Water level in observation well $19 \mathrm{HH} 12$, Madison County. 
335517084164001 Local number, 11 FF04.

LOCATION.--Lat $33^{\circ} 55^{\prime} 17^{\prime \prime}$, long 84 $16^{\circ} 40^{\prime \prime}$, Hydrologic Unit 03130001.

Owner: U.S. Geological Survey.

INSTRUMENTATION.--Digital recorder.

AQUIFER.--Crystalline rock.

WELL CHARACTERISTICS.--Drilled, observation well, diameter 6 in., depth $620 \mathrm{ft}$, cased to $36 \mathrm{ft}$, open hole.

DATUM.--Altitude of land-surface datum is $950 \mathrm{ft}$.

REMARKS.--Borehole geophysical survey conducted April 18, 1980.

PERIOD OF RECORD.--February 1980 to current year.

EXTREMES FOR PERIOD OF RECORD.--Highest water level, $4.98 \mathrm{ft}$ below land-surface datum, March 17, 1990; lowest,

$7.77 \mathrm{ft}$ below land-surface datum, October 14, 1993.

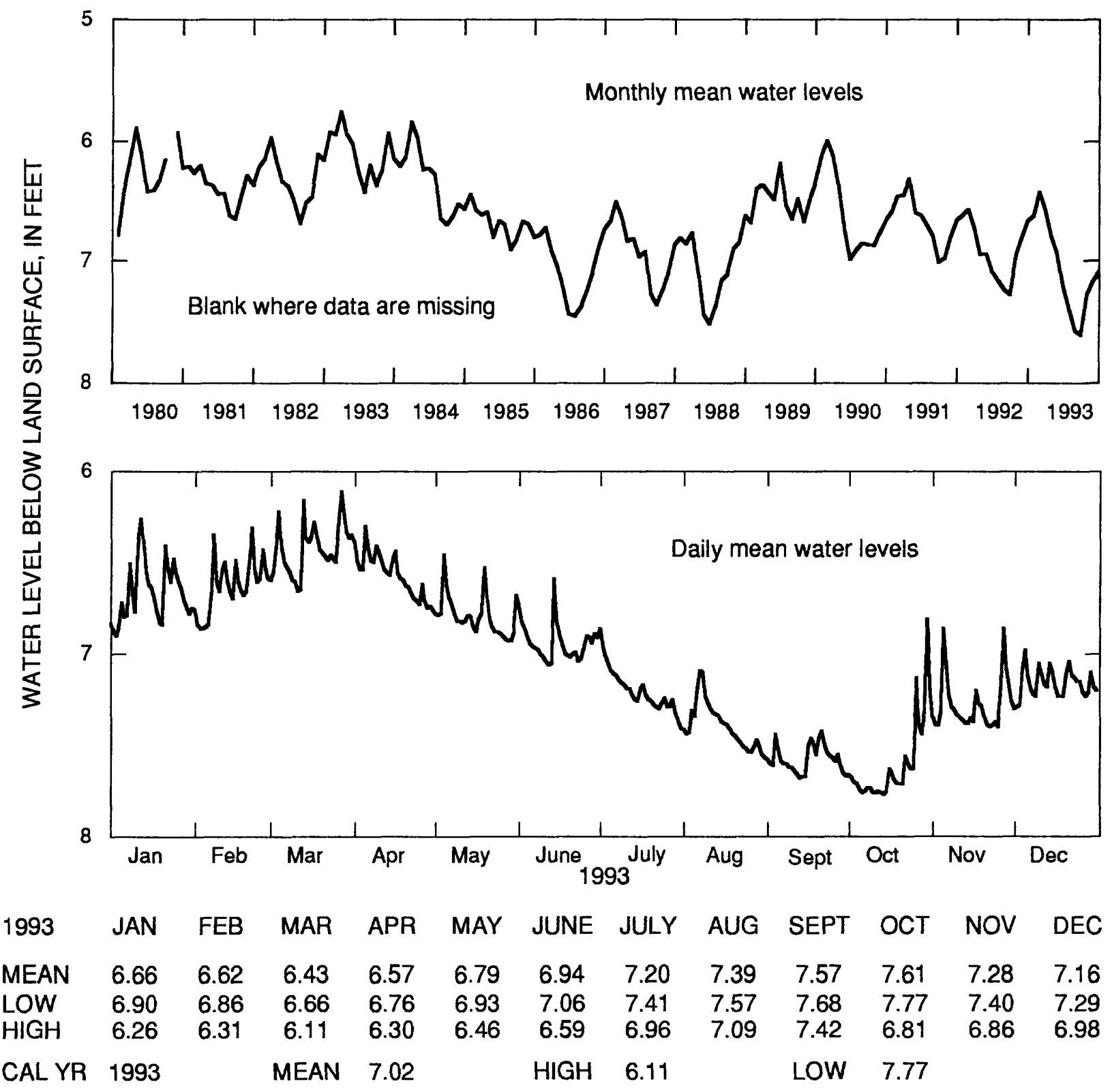

Figure 93.--Water level in observation well 11FF04, DeKalb County. 
332808083010201 Local number, $21 \mathrm{BB} 04$.

LOCATION.--Lat $33^{\circ} 28^{\prime} 08^{\prime \prime}$, long $83^{\circ} 01^{\prime} 02^{\prime \prime}$, Hydrologic Unit 03070101.

Owner: Charles Veazey.

INSTRUMENTATION.--Analog recorder.

AQUIFER.--Crystalline rock.

WELL CHARACTERISTICS.--Drilled, unused supply well, diameter 6 in., depth $497 \mathrm{ft}$, cased to $15 \mathrm{ft}$, open hole.

DATUM.--Altitude of land-surface datum is $675 \mathrm{ft}$.

REMARKS.--Borehole geophysical survey conducted March 13, 1987. Water levels for periods of missing record, March 14-20, October 23-29, and November 2-3, were estimated.

PERIOD OF RECORD.--March 1987 to current year.

EXTREMES FOR PERIOD OF RECORD.--Highest water level, $1.25 \mathrm{ft}$ above land-surface datum, March 28, 1993; lowest,

$7.58 \mathrm{ft}$ below land-surface datum, December 7, 1987.

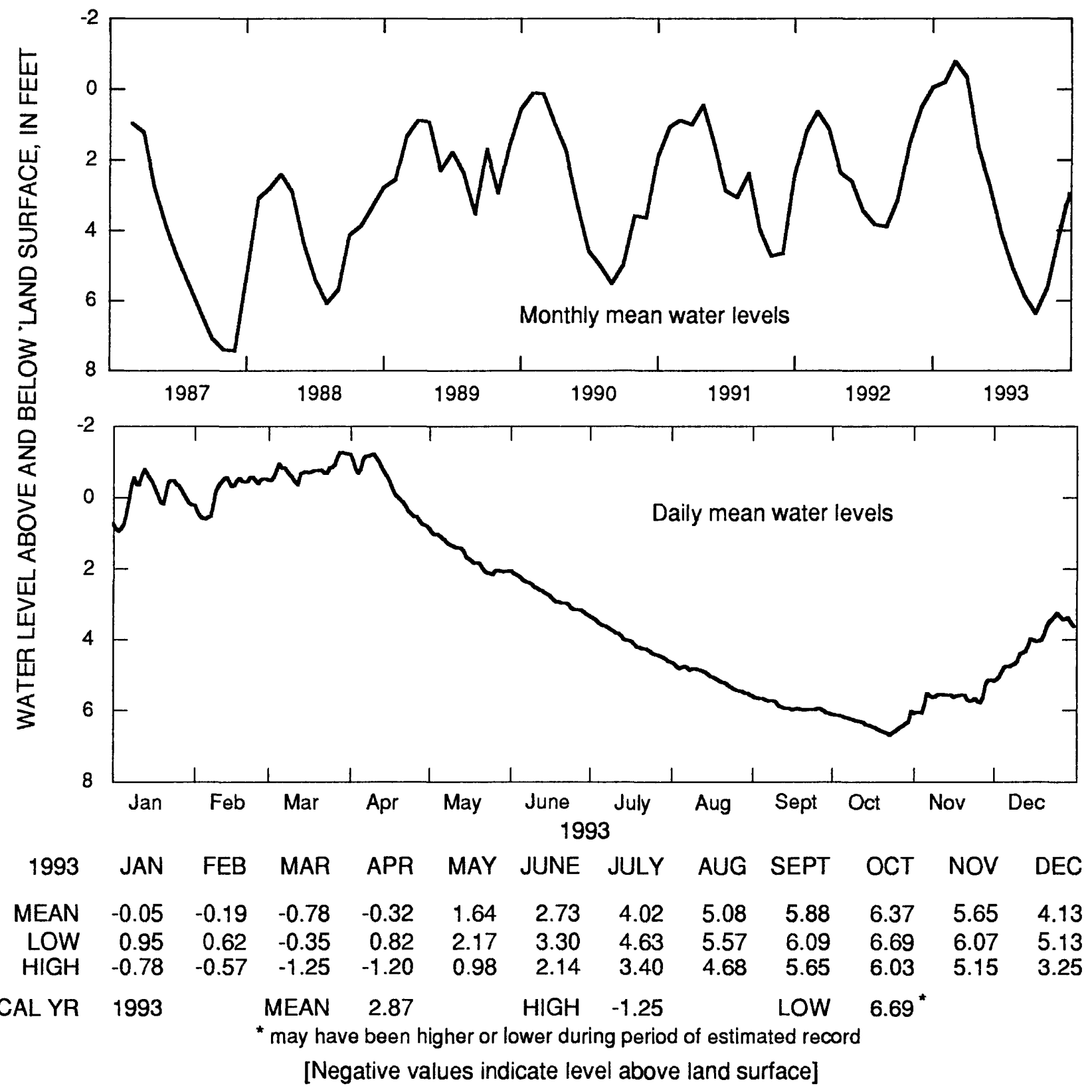

Figure 94.--Water level in observation well 21BB04, Greene County. 
344314083433201 Local number, 16MM03.

LOCATION.--Lat 3443'14", long 8343'32", Hydrologic Unit 03130001.

Owner: Unicoi State Park.

INSTRUMENTATION.--Digital recorder.

AQUIFER.--Crystalline rock.

WELL CHARACTERISTICS.--Drilled, unused supply well, diameter $6.25 \mathrm{in}$., depth $400 \mathrm{ft}$, cased to $72 \mathrm{ft}$, open hole.

DATUM.--Altitude of land-surface datum is $1550 \mathrm{ft}$.

REMARKS.--Borehole geophysical survey conducted December 7, 1987. Water levels for period of missing record, December 16-31, were estimated.

PERIOD OF RECORD.--May 1988 to current year.

EXTREMES FOR PERIOD OF RECORD.--Highest water level, $0.74 \mathrm{ft}$ above land-surface datum, March 17, 1989; lowest, $5.59 \mathrm{ft}$ below land-surface datum, September 2, 1988 .

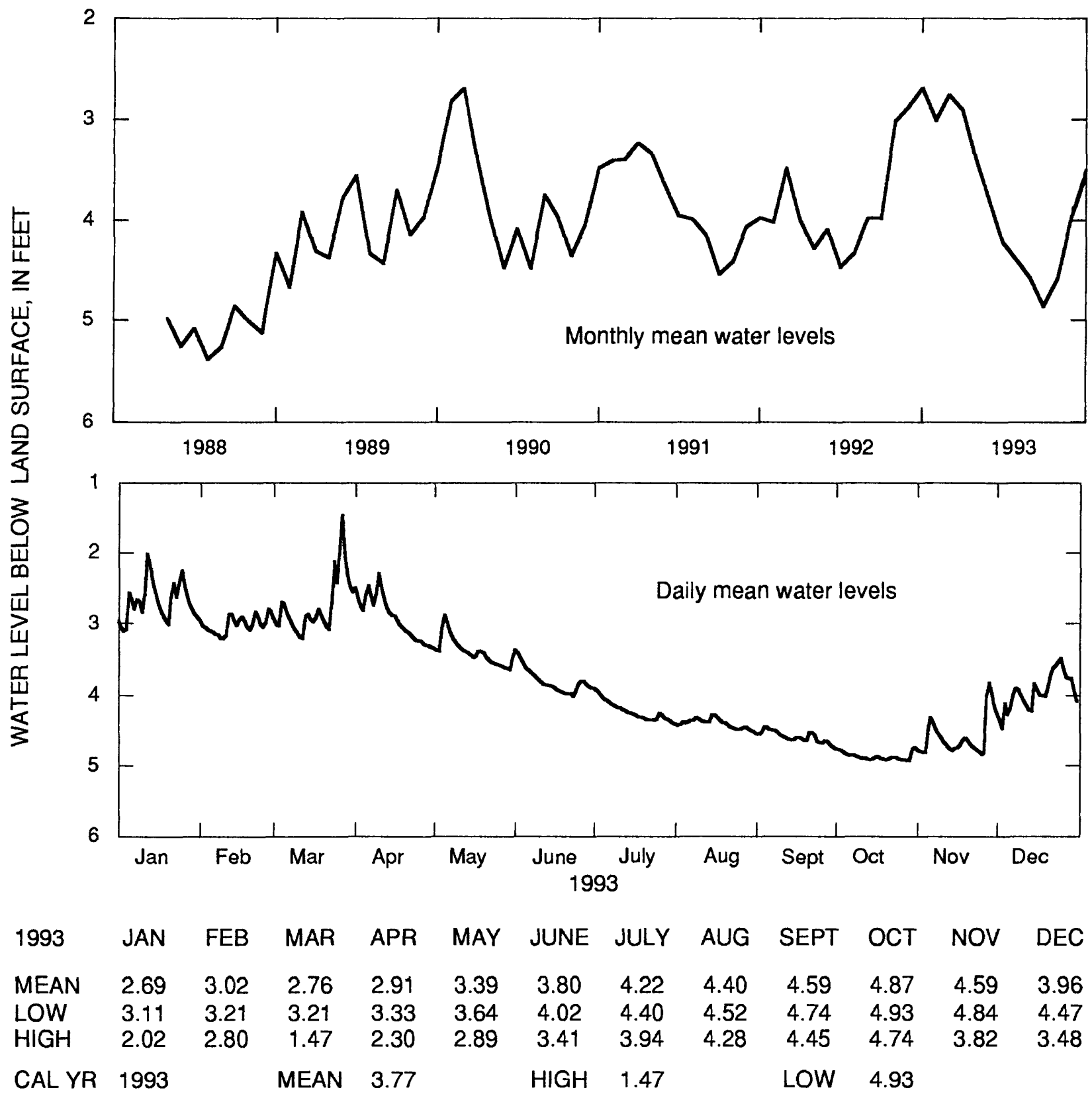

Figure 95.--Water level in observation well 16MM03, White County. 


\section{CHLORIDE CONCENTRATION IN WATER FROM THE FLORIDAN AQUIFER SYSTEM}

Chloride concentration in water from the Floridan aquifer system has been monitored periodically in coastal Georgia since the 1950's. During April and October 1993, water samples were collected from 96 wells that tap the Floridan aquifer system in the Savannah and Brunswick areas and were analyzed for chloride concentration. Graphs of chloride concentration in water for 13 of these wells (fig. 96; table 4) are shown in figures $97-100 .^{\circ}$ Chloride concentration in water from the Upper Floridan aquifer in most of the coastal Georgia area is less than 40 milligrams per liter $(\mathrm{mg} / \mathrm{L})($ Clarke and others, 1990, p. 48), which is lower than the $250 \mathrm{mg} / \mathrm{L}$ drinking-water standard established by the Georgia Department of Natural Resources (1977) and the U.S. Environmental Protection Agency (1990). Chloride concentration in water from the Upper Floridan aquifer that exceeds drinking-water standards has been detected only in the Brunswick area. Water in the Lower Floridan aquifer generally has high chloride concentration in the Savannah and Brunswick areas. Chloride concentration in water from the Fernandina permeable zone at the base of the Lower Floridan aquifer has been measured as high as $30,000 \mathrm{mg} / \mathrm{L}$ (Krause and Randolph, 1989, p. D51).

Table 4.--Observation wells for which chloride concentration graphs are included in this report

\begin{tabular}{|c|c|c|c|}
\hline County & Aquifer & $\begin{array}{l}\text { Well } \\
\text { number }\end{array}$ & Well name \\
\hline Chatham & Lower Floridan & 38Q196 & Test well 1 point 2 \\
\hline Chatham & Lower Floridan & $39 Q 017$ & Test well 7 point 1 \\
\hline Chatham & Lower Floridan & 390018 & Test well 7 point 2 \\
\hline Chatham & Lower Floridan & $38 Q 004$ & Test well 4 \\
\hline Chatham & Upper Floridan & $37 Q 185$ & Hutchinson Island test well 1 \\
\hline Glynn & Upper Floridan, upper water-bearing zone & $34 \mathrm{H} 393$ & Test well 17 \\
\hline Glynn & Upper Floridan, lower water-bearing zone & $34 \mathrm{H} 403$ & Test well 24 \\
\hline Glynn & Lower Floridan, brackish-water zone & 34H399 & Test well 19 \\
\hline Glynn & Lower Floridan, brackish-water zone & $34 \mathrm{H} 391$ & Test well 16 \\
\hline Glynn & Upper Floridan, upper water-bearing zone & $34 \mathrm{H} 469$ & Test well 2 \\
\hline Glynn & Upper Floridan, upperwater-bearing zone & $34 \mathrm{H} 427$ & E.M. Champion well 2 \\
\hline Glynn & Upper Floridan, upper water-bearing zone & $33 \mathrm{H} 133$ & Test well 6 \\
\hline Glynn & Upper Floridan, lower water-bearing zone & $33 \mathrm{H} 127$ & Test well 3 \\
\hline
\end{tabular}




\section{Savannah Area}

Twelve wells are currently sampled semi-annually in Chatham County, five of which are summarized in figures 96 and 97. Data from these wells indicate that chloride concentration generally increases with depth below land surface and is not changing appreciably with time (fig. 97). 


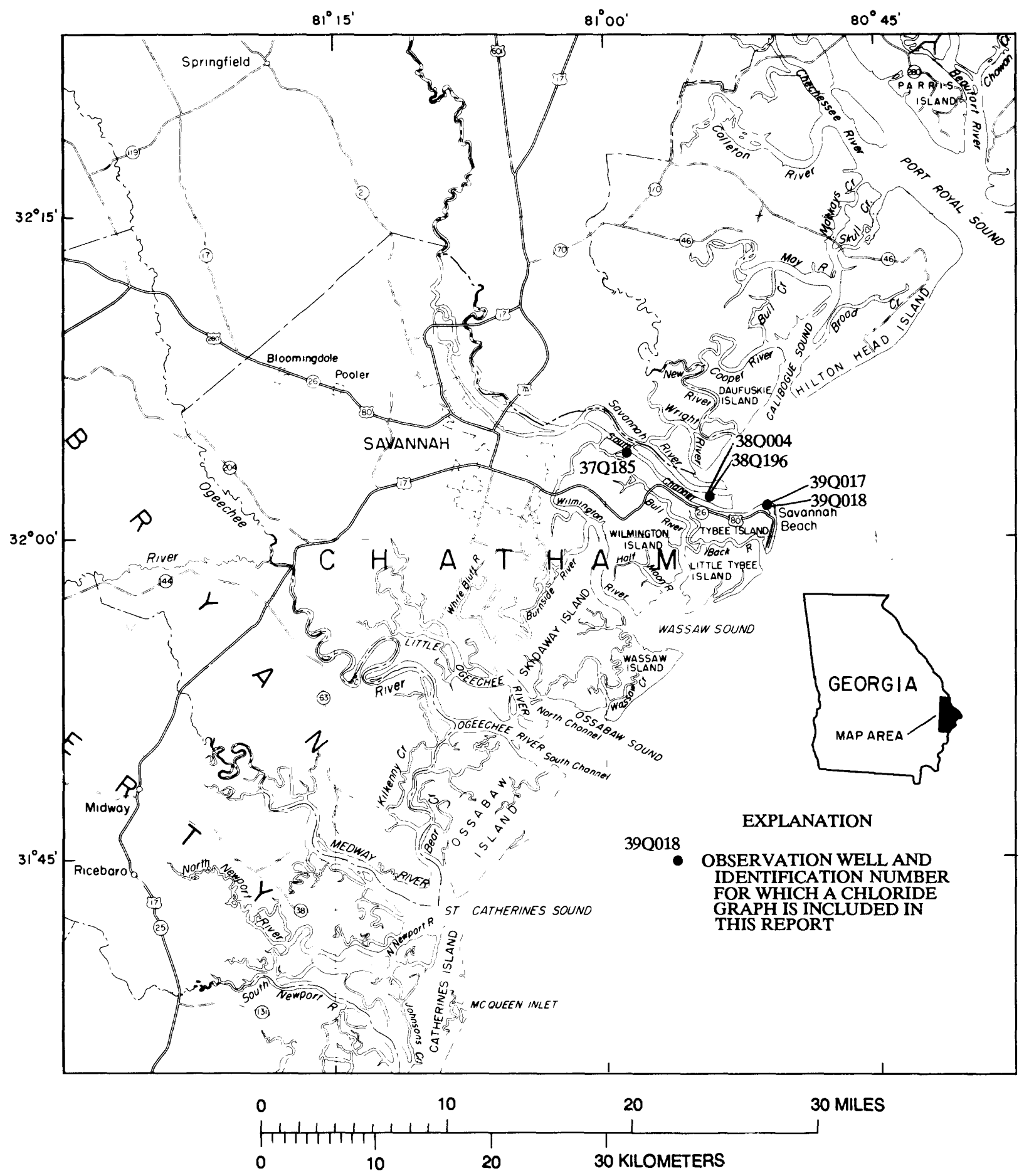

Figure 96.--Locations of chloride monitoring wells completed in the Floridan aquifer system in the Savannah area. 


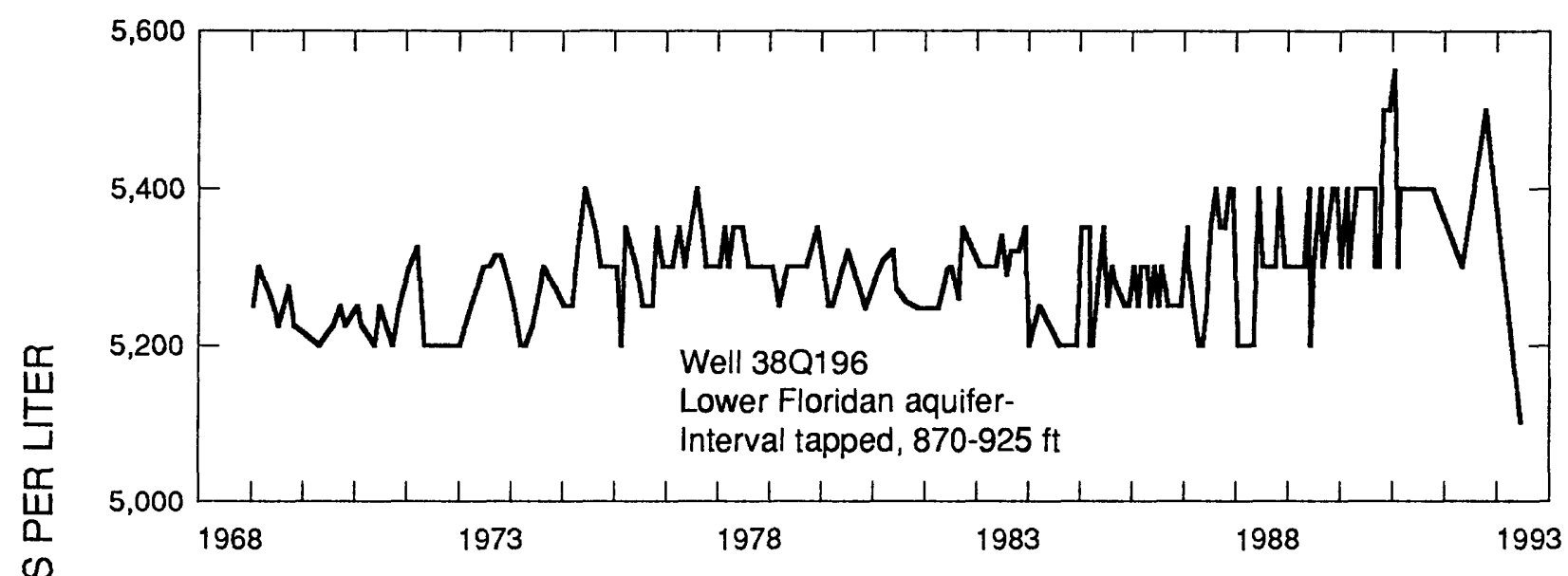

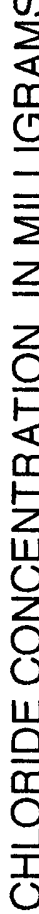

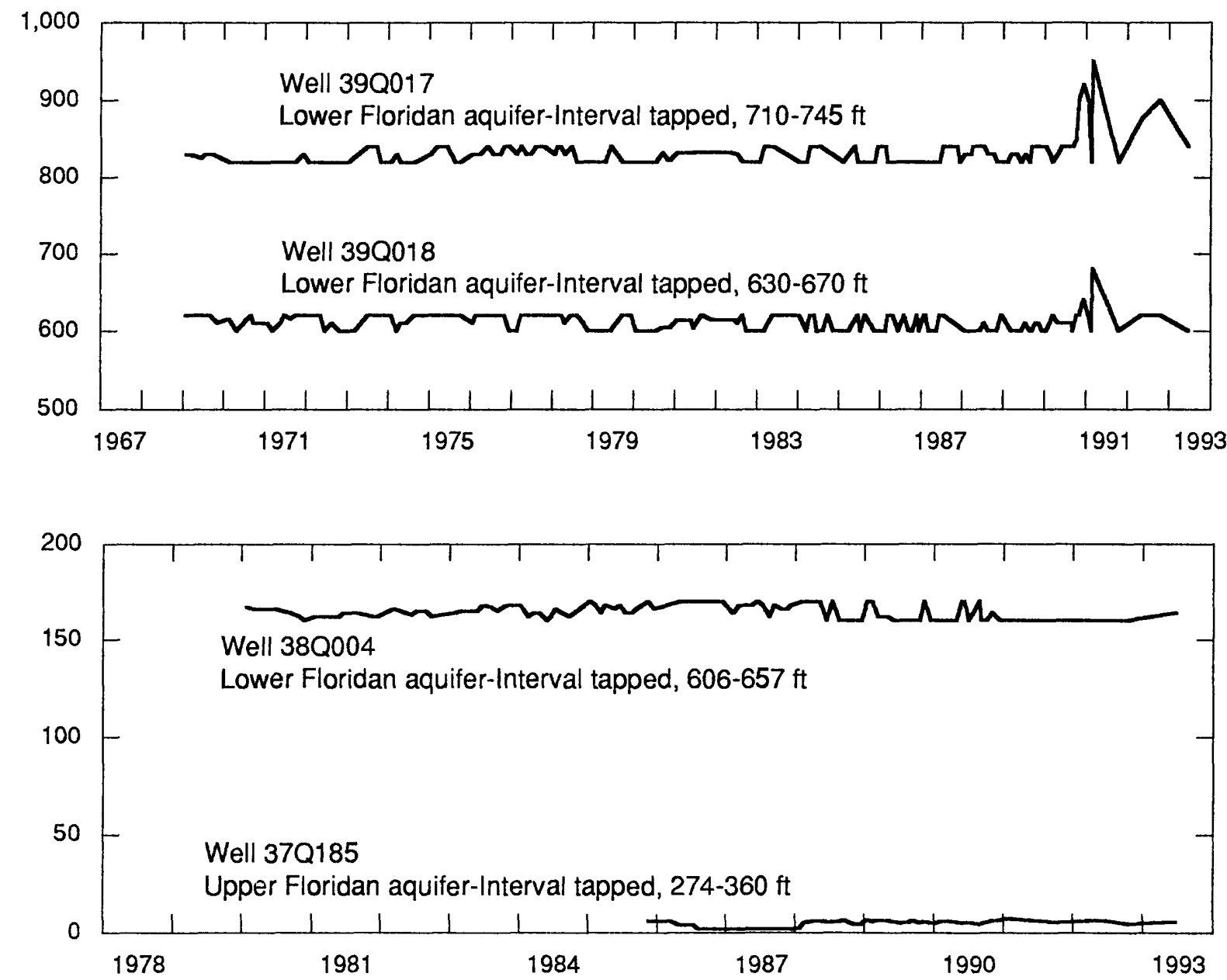

Figure 97.--Chloride concentration in water from the Upper and Lower Floridan aquifers in the Savannah area. 


\section{Brunswick Area}

Since pumping began in the Brunswick area in the late 1800's, ground-water withdrawal has lowered the water level in the Upper Floridan aquifer (Krause and Randolph, 1989). This water-level decline has allowed saltwater to migrate upward into the Upper Floridan aquifer in Brunswick from the Fernandina permeable zone, which is at the base of the Lower Floridan aquifer (Krause and Randolph, 1989, p. D51). Chloride concentration in water from the upper water-bearing zone of the Upper Floridan aquifer is greater than $2,000 \mathrm{mg} / \mathrm{L}$ in parts of Brunswick.

In the Brunswick, Glynn County area, 84 wells are currently pumped and sampled semi-annually for chloride analysis. Graphs of chloride concentration in water from eight wells tapping various zones of the Floridan aquifer system (located on fig. 98) are shown in figures 99 and 100.

The chloride concentration in water from wells $34 \mathrm{H} 469$ and $34 \mathrm{H} 427$, which tap the upper waterbearing zone of the Upper Floridan aquifer in the northern Brunswick area, are shown in figure 100. The chloride concentration in water from wells $33 \mathrm{H} 133$ and 33H127 (fig. 100) which tap the upper and lower water-bearing zones of the Upper Floridan aquifer, respectively, show an upward trend since sampling began in 1966. 


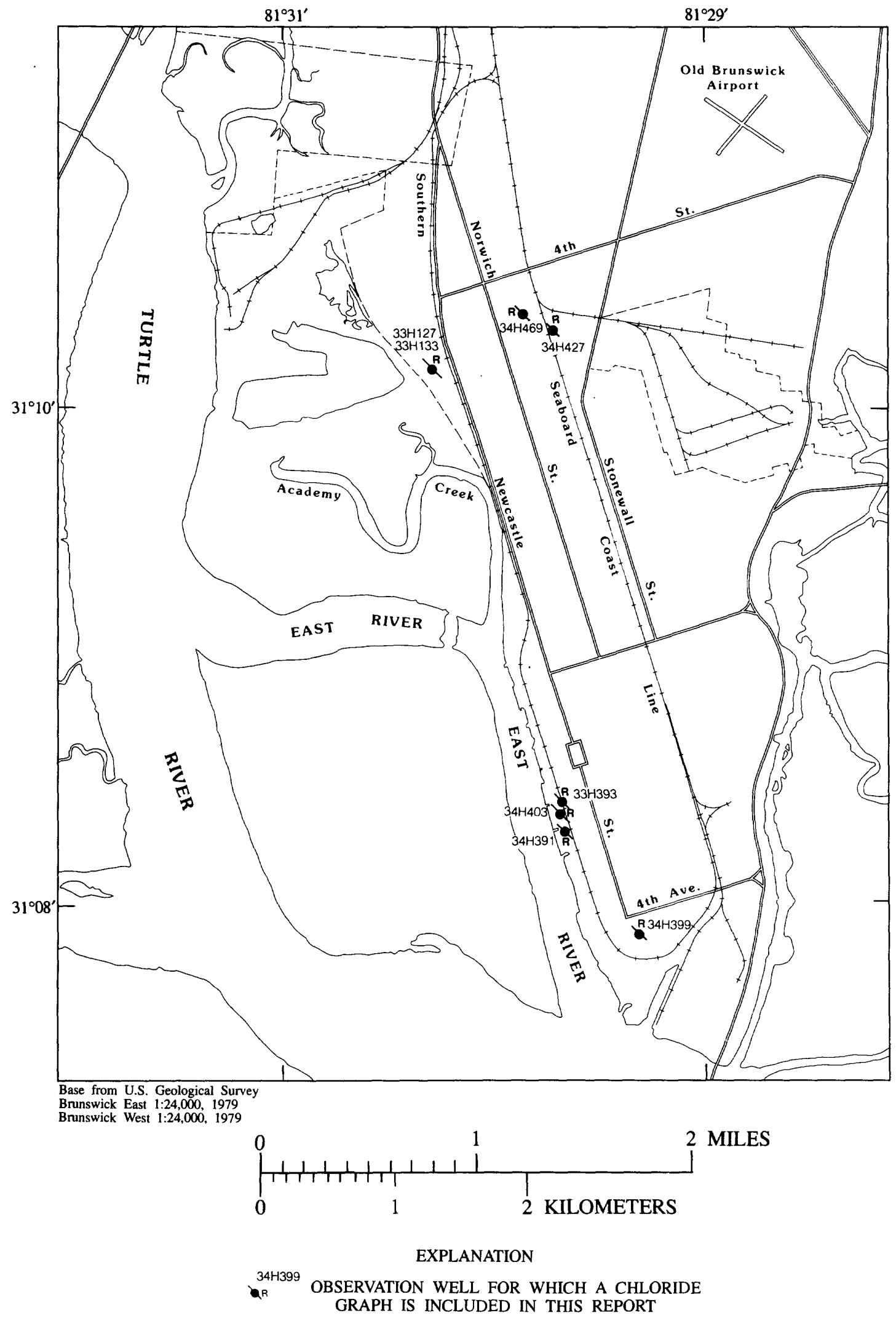

Figure 98.--Locations of chloride-monitoring wells completed in the Floridan aquifer system in the Brunswick area. 

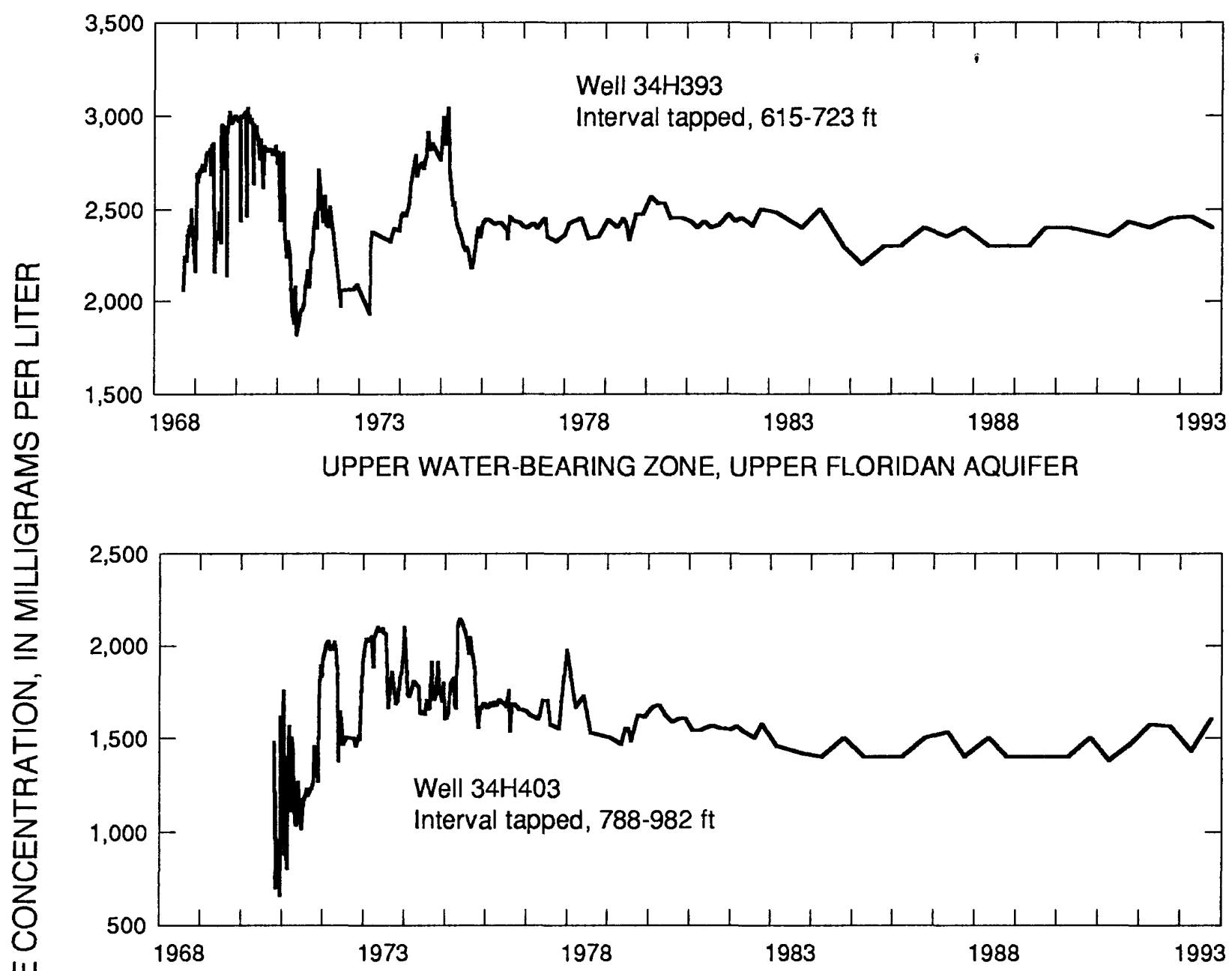

LOWER WATER-BEARING ZONE, UPPER FLORIDAN AQUIFER

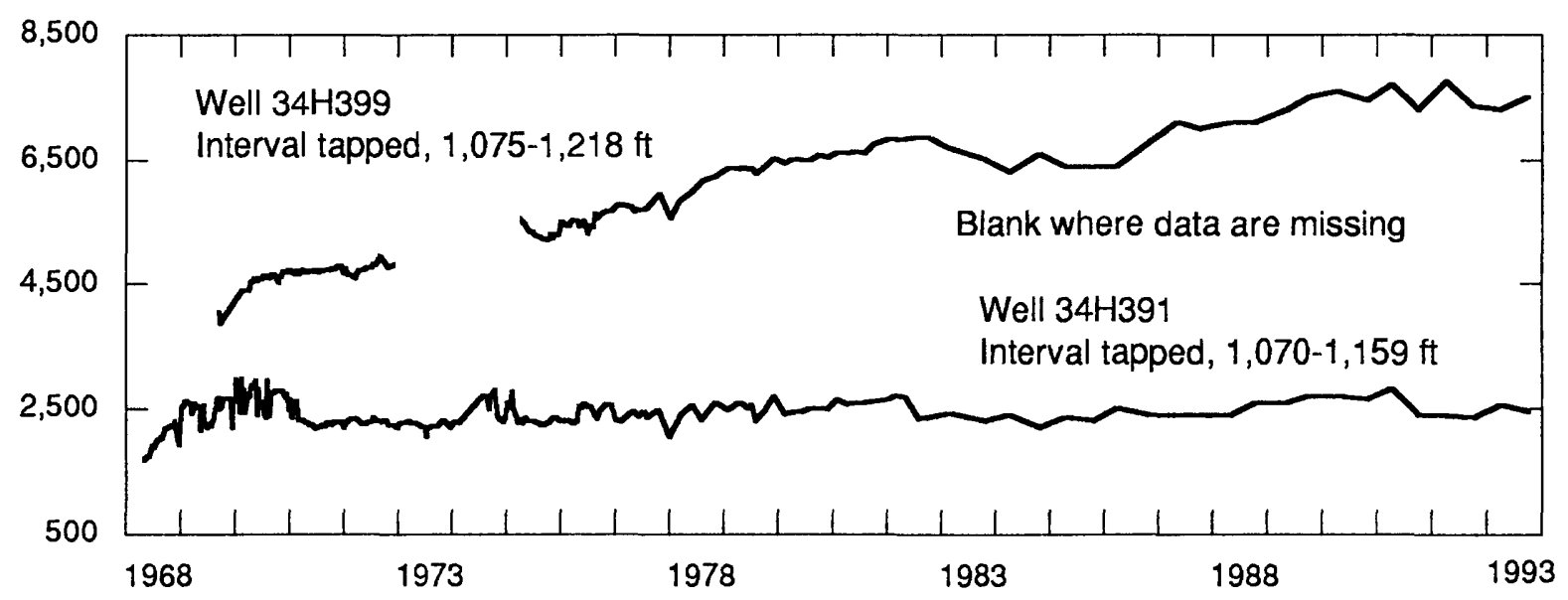

BRACKISH-WATER ZONE, LOWER FLORIDAN AQUIFER

Figure 99.--Chloride concentration in water from the Floridan aquifer system in the southern Brunswick area. 


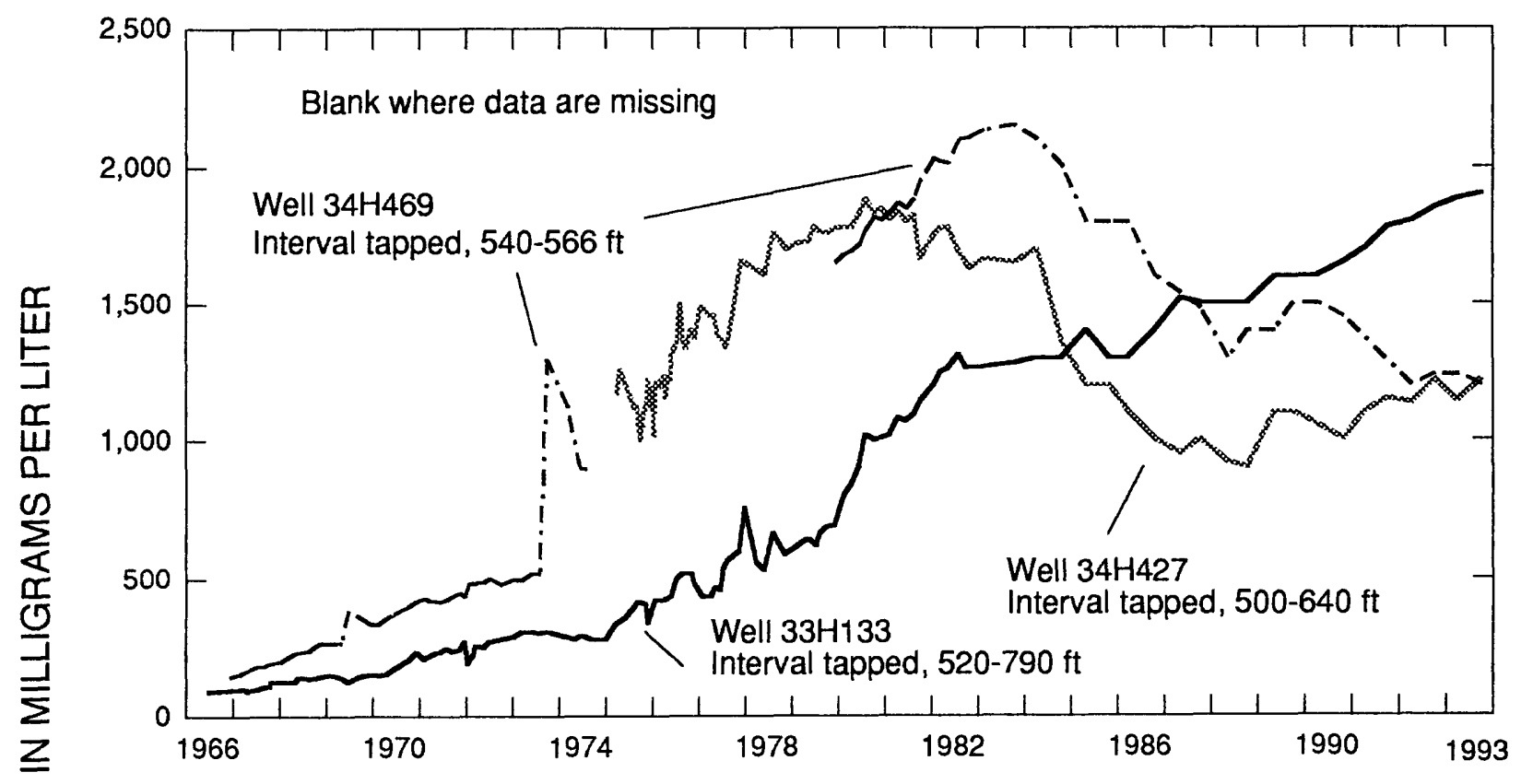

Z⿱

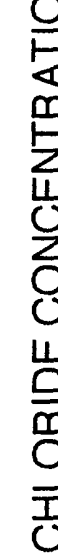

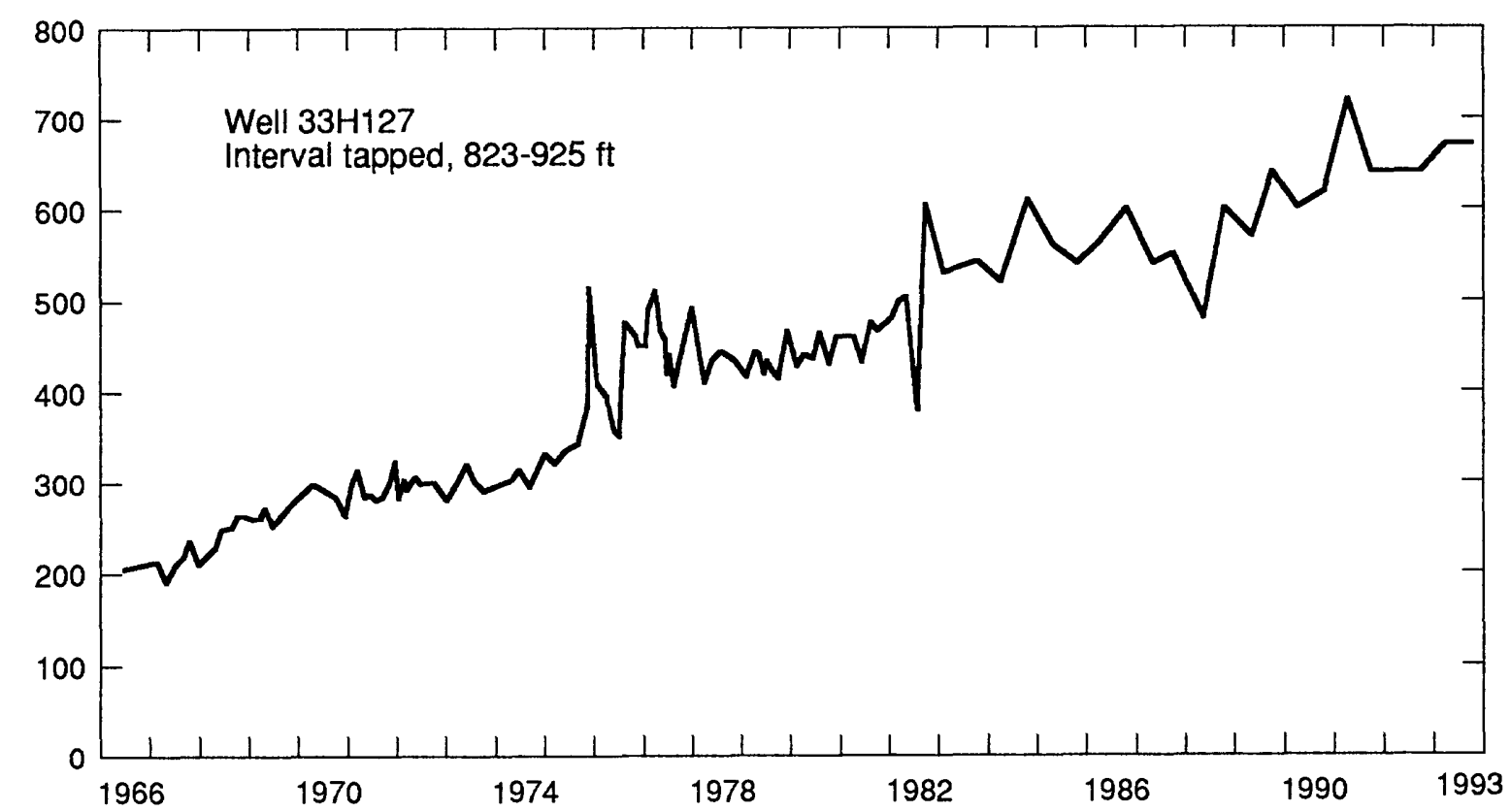

LOWER-WATER BEARING ZONE OF THE UPPER FLORIDAN AQUIFER

Figure 100.-- Chloride concentration in water from the Floridan aquifer system in the northern Brunswick area. 


\section{SELECTED REFERENCES}

Brooks, Rebekah, Clarke, J.S., and Faye, R.E., 1985, Hydrogeology of the Gordon aquifer system of east central Georgia: Georgia Geologic Survey Information Circular 75, 41 p.

Carter, R.F., and Stiles, H.R., 1983, Average annual rainfall and runoff in Georgia, 1941-70: Georgia Geologic Survey Hydrologic Atlas 9, 1 sheet.

Clarke, J.S., Faye, R.E., and Brooks, Rebekah, 1983, Hydrogeology of the Providence aquifer of southwest Georgia: Georgia Geologic Survey Hydrologic Atlas 11, 5 sheets.

Clarke, J.S., and Pierce, R.R., 1984, Georgia water facts--ground-water resources in the United States, in National Water Summary, 1984: U.S. Geological Survey Water-Supply Paper 2275, p. 179-184.

Clarke, J.S., Brooks, Rebekah, and Faye, R.E., 1985, Hydrology of the Dublin and Midville aquifer system of east-central Georgia: Georgia Geologic Survey Information Circular 74, 62 p.

Clarke, J.S., 1987, Potentiometric surface of the Upper Floridan aquifer, May 1985, and water-level trends, 1980-85: Georgia Geologic Survey Hydrologic Atlas 16, scale 1:1,000,000, 1 sheet.

Clarke, J.S., Hacke, C.M., and Peck, M.F., 1990, Geology and ground-water resources of the the coastal area of Georgia: Georgia Geologic Survey Bulletin 113, 106 p.

Clarke, J.S., and Peck, M.F., 1990, Ground-water resources of the south Metropolitan Atlanta region, Georgia: Georgia Geologic Survey Information Circular 88, 56 p.

Counts, H.B., and Donsky, Ellis, 1963, Salt-water encroachment, geology, and ground-water resources of the Savannah area, Georgia and South Carolina: U.S. Geological Survey Water-Supply Paper 1611, $100 \mathrm{p}$.

Cressler, A.M., 1991, Chloride concentrations in the Upper Floridan aquifer in the coastal area of Georgia, May 1990: U.S. Geological Survey Open-File Report 91-173, 1p.

Cressler, A.M., 1994, Potentiometric surfaces of the Upper Floridan aquifer, Valdosta area, Georgia, June 3-4, 1991 and March 29 to April 2, 1993: U.S. Geological Survey Water-Resources Investigations Report 93-361, 2 p.

Cressler, C.W., 1964, Geology and ground-water resources of Walker County, Georgia: Georgia Geologic Survey Information Circular 29, 15 p.

Cressler, C.W., Thurmond, C.J., and Hester, W.G., 1983, Ground water in the Greater Atlanta region, Georgia: Georgia Geologic Survey Information Circular 63, 144 p.

Faye, R.E., and McFadden, K.W., 1988, Hydraulic characteristics of Upper Cretaceous and lower tertiary clastic aquifers--eastern Alabama, Georgia, and western South Carolina: U.S. Geological Survey Water-Resources Investigations Report 86-4210, 22 p.

Garza, Reggina, and Krause, R.E., 1992, Water-supply potential of major streams and the Upper Floridan aquifer in the vicinity of Savannah, Georgia: U.S. Geological Survey Open-File Report 92-629, 49 p.

Georgia Department of Natural Resources, 1977, Rules for safe drinking water: Atlanta, Ga., Department of Natural Resources, Environmental Protection Division, Chapter 391-3-5, p. 601-657.

Gorday, L.L., 1985, The hydrogeology of the Coastal Plain strata of Richmond and northern Burke Counties, Georgia: Georgia Geologic Survey Information Circular 61, 43 p.

---- 1990, The hydrogeology of Lamar County, Georgia: Georgia Geologic Survey Information Circular $80,40 \mathrm{p}$.

Grantham, R.G., and Stokes, W.R., III, 1976, Ground-water-quality data for Georgia: Atlanta, Ga., U.S. Geological Survey, $216 \mathrm{p}$. 


\section{SELECTED REFERENCES--Continued}

Gregg, D.O., and Zimmerman, E.A., 1974, Geologic and hydrologic control of chloride contamination in aquifers at Brunswick, Glynn County, Georgia: U.S. Geological Survey Water-Supply Paper 2029-D, $44 \mathrm{p}$.

Hayes, R.H., Maslia, M.L., and Meeks, W.C., 1983, Hydrology and model evaluation of the principal artesian aquifer, Dougherty Plain, southwest Georgia: Georgia Geologic Survey Bulletin 97, 93 p.

Hicks, D.W., Krause, R.E., and Clarke, J.S., 1981, Geohydrology of the Albany area Georgia: Georgia Geologic Survey Information Circular 57, $31 \mathrm{p}$.

Hicks, D.W., Gill, H.E., and Longsworth, S.A., 1987, Hydrology, chemical quality, and availability of ground water in the Upper Floridan aquifer, Albany area, Georgia: U.S. Geological Survey WaterResources Investigations Report 87-4145, 52 p.

Joiner, C. N., 1991, Chloride concentrations in the upper water-bearing zone of the Upper Floridan aquifer in the Brunswick area, Georgia, October-November 1990: U.S. Geological Survey Open-File Report 91-174, 1p.

Krause, R.E., 1972, Effects of ground-water pumping in parts of Liberty and McIntosh Counties, Georgia, 1966-70: Georgia Geologic Survey Information Circular 45, 15 p.

... 1979, Geohydrology of Brooks, Lowndes, and western Echols Counties, Georgia: U.S. Geological Survey Water-Resources Investigations Report 78-117, 48 p.

Krause, R.E., and Randolph, R.B., 1989, Hydrogeology of the Floridan aquifer system in southeast Georgia and adjacent parts of Florida and South Carolina: U.S. Geological Survey Professional Paper 1403-D, $65 \mathrm{p}$.

Marella, R.L., Fanning, J.L. and Mooty, W.S., 1993, Estimated Use Of Water in the ApalachicolaChattahoochee-Flint River Basin during 1990 with State Summaries from 1970 to 1990: U.S. Geological Survey Water Resources Investigation Report 93-4084, 45 p.

Maslia, M.L., and Hayes, L.R., 1986, Hydrogeology and simulated effects of ground-water development of the Floridan aquifer system, southwest Georgia, northwest Florida, and extreme southern Alabama: U.S. Geological Survey Professional Paper 1403-H, 71 p.

McCollum, M.J., and Counts, H.B., 1964, Relation of salt-water encroachment to the major aquifer zones, Savannah area, Georgia and South Carolina: U.S. Geological Survey Water-Supply Paper 1613-D, $26 \mathrm{p}$.

Miller, J.A., 1986, Hydrogeologic framework of the Floridan aquifer system in Florida and parts of Georgia, Alabama, and South Carolina: U.S. Geological Survey Professional Paper 1403-B, 91 p.

National Oceanic and Atmospheric Administration, 1992, Climatological data, Georgia, JanuaryDecember 1992, v. 96, no. 1-12.

Peck, M.F., 1991, Potentiometric surface of the Upper Floridan aquifer in Georgia and adjacent parts of Alabama, Florida, and South Carolina, May-June 1990: U.S. Geological Survey Open-File Report 91-206, 3 p.

Peck, M.F., and Allen, R.J., 1991, Potentiometric surface of the Clayton aquifer in Georgia, October 1990: U.S. Geological Survey Open-file Report 91-208, 2 p.

Peck, M.F., and Cressler, A.M., 1993, Ground-water conditions in Georgia, 1992: U.S. Geological Survey Open-File Report 93-358, 134 p.

Randolph, R.B., and Krause, R.E., 1984, Analysis of the effects of proposed pumping from the principal artesian aquifer, Savannah, Georgia area: U.S. Geological Survey Water-Resources Investigations Report 84-4064, 26 p.

-..- 1990, Analysis of the effects of hypothetical changes in ground-water withdrawal from the Floridan aquifer system in the area of Glynn County, Georgia: U.S. Geological Survey Water-Resources Investigations Report 90-4027, $32 \mathrm{p}$.

Radtke, D.B., Cressler, C.W., Perlman, H.A., Blanchard, H.E., Jr., McFadden, K.W., and Brooks, Rebekah, 1986, Occurrence and availability of ground water in the Athens region, northeastern Georgia: U.S. Geological Survey Water-Resources Investigations Report 86-4075, 79 p. 


\section{SELECTED REFERENCES--Continued}

Torak, L.J., Davis, G.S., Strain, G.A., and Herndon, J.G., 1991, Geohydrology and evaluation of waterresource potential of the Upper Floridan aquifer in the Albany area, southwestern Georgia: U.S. Geological Survey Water-Supply Paper 2391, 59 p.

Vorhis, R.C., 1973, Geohydrology of Sumter, Dooly, Pulaski, Lee, Crisp, and Wilcox Counties, Georgia: U.S. Geological Survey Hydrologic Investigations Atlas HA-435, 1 sheet.

Wait, R.L., and Gregg, D.O., 1973, Hydrology and chloride contamination of the principal artesian aquifer in Glynn County, Georgia: Georgia Geologic Survey Hydrologic Report 1, 21 p.

Watson, T.W., 1984, Hydrogeology of Greene, Morgan, and Putnam Counties: Georgia Geologic Survey Information Circular 60, $16 \mathrm{p}$.

U.S. Environmental Protection Agency, 1990, Drinking water regulations under the Safe Drinking Water Act: Washington, D.C., U.S. Environmental Protection Agency, Criteria and Standards Division, Office of Drinking Water, SDWA Fact Sheet, 45 p. 